\title{
Capital at the Brink
}

Overcoming the Destructive Legacies of Neoliberalism

Edited by Jeffrey R. Di Leo and Uppinder Mehan 

Capital at the Brink 


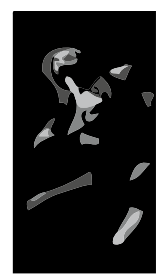

\section{Critical Climate Change}

Series Editors: Tom Cohen and Claire Colebrook

The era of climate change involves the mutation of systems beyond 20th century anthropomorphic models and has stood, until recently, outside representation or address. Understood in a broad and critical sense, climate change concerns material agencies that impact on biomass and energy, erased borders and microbial invention, geological and nanographic time, and extinction events. The possibility of extinction has always been a latent figure in textual production and archives; but the current sense of depletion, decay, mutation and exhaustion calls for new modes of address, new styles of publishing and authoring, and new formats and speeds of distribution. As the pressures and realignments of this re-arrangement occur, so must the critical languages and conceptual templates, political premises and definitions of 'life.' There is a particular need to publish in timely fashion experimental monographs that redefine the boundaries of disciplinary fields, rhetorical invasions, the interface of conceptual and scientific languages, and geomorphic and geopolitical interventions. Critical Climate Change is oriented, in this general manner, toward the epistemopolitical mutations that correspond to the temporalities of terrestrial mutation. 


\title{
Capital at the Brink \\ Overcoming the Destructive Legacies of Neoliberalism
}

edited by Jeffrey R. Di Leo and Uppinder Mehan

\author{
() \\ OPEN HUMANITIES PRESS \\ An imprint of Michigan Publishing \\ University of Michigan Library, Ann Arbor
}

2014 


\section{First edition published by OPEN HUMANITIES PRESS}

Freely available online at http://dx.doi.org/10.3998/ohp.12832551.0001.001

Copyright ( 2014 Jeffrey R. Di Leo and Uppinder Mehan, chapters by respective Authors

This is an open access book, licensed under Creative Commons By Attribution Share Alike license. Under this license, authors allow anyone to download, reuse, reprint, modify, distribute, and/or copy their work so long as the authors and source are cited and resulting derivative works are licensed under the same or similar license. No permission is required from the authors or the publisher. Statutory fair use and other rights are in no way affected by the above.

Read more about the license at creativecommons.org/licenses/by-sa/3.0

Cover Art, figures, and other media included with this book may be under different copyright restrictions. Please see the Permissions section at the back of this book for more information.

ISBN 978-1-60785-306-0

OPEN HUMANITIES PRESS is an international, scholar-led open access publishing collective whose mission is to make leading works of contemporary critical thought freely available worldwide. Books published under the open humanities press imprint at Michigan Publishing are produced through a unique partnership between OHP's editorial board and the University of Michigan Library, which provides a library-based managing and production support infrastructure to facilitate scholars to publish leading research in book form.

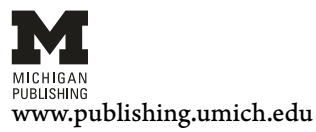

\section{()}

OPEN HUMANITIES PRESS www.openhumanitiespress.org 


\section{Contents}

Acknowledgements

Introduction: The Wrath of Capital

Jeffrey R. Di Leo and Uppinder Mehan

I Race, Violence, and Politics

1. Neoliberalism and Violent Appearances

Paul A. Passavant

2. The Turn to Punishment: Racism, Domination, and the Neoliberal Era

Noah De Lissovoy

3. Neoliberalism, Environmentality, and the Specter of Sajinda Khan

Robert P. Marzec

4. Rhetorical Assemblages: Scales of Neoliberal Ideology

Jennifer Wingard

5. Neoliberalism, Autoimmunity and Democracy:

Derrida and the Neoliberal Ethos

Zahi Zalloua

II Literature, Culture, and the Self

6. Complexity as Capture: Neoliberalism and the Loop of Drive

Jodi Dean

7. Neoliberalism, Risk, and Uncertainty in the Video Game Andrew Baerg 
8. Neoliberalism in Publishing: A Prolegomenon 215 Jeffrey R. Di Leo

9. The Post-Political Turn: Theory in the Neoliberal Academy 241 Christopher Breu

10. Neoliberalism, Post-Scarcity, and the Entrepreneurial Self 259 Uppinder Mehan

Notes on Contributors 
"Under neoliberalism everything either is for sale or is plundered for profit."

Henry Giroux,

The Terror of Neoliberalism 



\section{Acknowledgements}

Our primary debt of gratitude goes out to the contributors to this volume for sharing their thoughts on the destructive legacies of neoliberalism. It is our hope that collectively their contributions will open up new lines of conversation about this important subject and work to create new paths and acts of resistance.

We would also like to single out Keri Farnsworth of symploke for her assistance in the production of this volume. Her timely support was instrumental in bringing this volume to publication.

Finally, we would like to thank our families for their unfailing encouragement, support, and patience. 



\title{
The Wrath of Capital
}

\author{
JefFrey R. Di Leo ANd UpPINDER MeHan
}

Since the 1970s, the US has seen a dramatic transformation of its economic and cultural landscape: the wage inequality gap between the middle class and the upper class has dramatically widened; at least two attempts have been made to privatize public schooling, the voucher system in the 1980s, and the Charter School movement in the 2000s; manufacturing jobs have fled the country; service jobs have been outsourced; membership in labor unions has declined from $34 \%$ to $8 \%$; women's rights and the ERA are increasingly under attack; and labor by illegal immigrants has steadily risen while attempts to naturalize them have faltered. During the same period, corporations and private business interests have made substantial gains both monetarily and politically. Over the last thirty years the cultural and economic gains solidified by the middle class in the 1950s and 60s, largely through the development of the New Deal consensus reached in the 1930s, have slowly dissipated.

None of this happened by accident or came to be as the working out of a natural process. Legislators moved by the demands, pressure, and financial gain offered by business enacted a series of decisions designed not only to make it easier for corporations to move capital and labor around the world as needed, but also for financial companies to socialize risk and privatize profit as well as offer the commons for sale. Ronald Reagan may have cut the top income tax rate from $70 \%$ to $28 \%$, and broke the Air Traffic Controllers strike and the union; Bill Clinton may have signed NAFTA into law, ended welfare as we know it, and repealed the Glass-Steagall Act also known as the Banking Act of 1933 that restricted 
banks from engaging in securities activities, but all politicians have felt the pressure of the Powell memo of 1971.

While the Washington Consensus and its blatantly neoliberal economic policies did not appear until the late 1980s, it was in the early 1970s that neoliberal capital's social and cultural work got under way. Two months before his nomination to the US Supreme court by Nixon, Lewis F. Powell drafted a memo for the Director of the US Chamber of Commerce in which he famously stated that the business community needed to engage in "careful long-range planning and implementation, in consistency of action over an indefinite period of years, in the scale of financing available only through joint effort, and in the political power available only through united action and national organizations." ${ }^{1}$ The American economic system was under attack and Powell wanted to urge the usually mild-mannered businessman to fight back. For too long, Powell argued, the forces of socialism and statism had been gaining ground in the US and the Chamber of Commerce had to act before it was too late. In addition to the usual Communist groups and sympathizers who were behind these forces, Powell identified "the college campus, the pulpit, the media, the intellectual and literary journals, the arts and sciences, and politicians."

The many enemies of the American economic system, as Powell understands it, have been working for a number of decades in molding public opinion and business should do likewise. While Powell's prescriptions for taking on the media have been commented upon quite frequently, few have remarked on how he also provided a blueprint for much conservative action with regard to higher education. Social science faculties across the country hold inimical attitudes to business according to Powell, and he singles out Herbert Marcuse as a "Marxist faculty member [then] at the University of California at San Diego" as an example of the powerful writers and magnetic personalities that turn the best and brightest young minds against free enterprise. He sees such faculty members as having an influence that far exceeds their numbers and urges the Chamber to pursue measures designed to restore the qualities of "openness" "fairness" and "balance" to academic freedom (quotation marks in the original suggest that Powell would not be surprised by the ironic use of those same words by Fox News). The Chamber of Commerce can get 
started by having a staff of senior business executives to "articulate the product of the scholars." The scholars would produce not only speeches and policy papers but also evaluate social science textbooks in terms of restoring the "balance" that the civil rights movement and labor unions have biased. The Chamber should insist on equal time on campus with the "avowed Communists" and "leftists and ultra liberals" who regularly speak at various events. Boards of trustees and alumni should be made to understand that the left-leaning faculties at American campuses need to be balanced, and perhaps most obviously graduate schools of business should be encouraged to train executives correctly. ${ }^{3}$

Increasingly so over the last decade, left-leaning commentators, politicians, and academics have looked for reasons behind the success conservatives have enjoyed in pushing their agenda. They have been surprised over and again by the willingness of voters to endorse policies that are clearly against their best economic and social interests. Many politicians and commentators such as Kevin Drum, who often writes for the "leftist" magazine Mother Jones, point to the concerted efforts of rightwing and conservative think tanks as outlined by Powell to promote a pro-business agenda as the norm. ${ }^{4}$ Scholars such the cognitive linguist George Lakoff, turn to the use of metaphorical language used by the two major US political parties. The Republicans, and conservatives in general, use language that reflects the image of the strict father; whereas, the Democrats, and liberals in general, use imagery associated with the nurturant father. ${ }^{5}$

While both Drum and Lakoff are correct, they miss the most powerful appeal used by the supporters and promoters of neoliberal ideology: individualism. Neoliberalism describes the conditions of labor in language deeply connected with the myth of the American individual who stands tall and fights alone against all manner of injustice. Positive words such as responsibility, efficiency, flexibility, autonomy, and responsibility are used to describe labor and the market. As an aside, the "market" itself has taken on almost reverential tones - it is a force beyond the limited understanding of those of us who do not operate in the world of high finance, and it can do no wrong. The notion of a "flexible" workforce, one where it is much easier to hire and fire someone, is conflated with the notion of a flexible person. Who, after all, would want to be seen as being rigid? At the same time, one cannot be too flexible for "responsibility" is 
a prized moral attribute. Responsibility also easily turns to blame with the individual bearing more and more of it. "Autonomy" is easily a code word for anti-collective and anti-union preferences, and "efficiency" is a measure of how more labor can be extracted from fewer workers. Individualism, though, is different from individualization, which means in neoliberal practice that "the individualized subject is held responsible for the unintended consequences of their chosen action.... Nobody else is to blame. There is no safe haven." ${ }^{6}$ The neoliberal appropriation of the rhetoric of the individual combines with preferences for privatization, free trade, unrestricted flow of capital, and austerity measures for middle and lower classes to produce an understanding of the self as an entrepreneur.

\section{From Serf to Entrepreneur}

The term neoliberalism is one of the stars that make up the constellation of terms central to contemporary discourse. Neoliberalism joins globalization, hegemony, cosmopolitanism and imperialism as a renewed focus of inquiry in post 9-11 debates about the shape of the world. As is the case with its partner terms, neoliberalism too has become a varied and variable term. It might prove beneficial to sort out two major senses of the word: ideological and economic. The economic sense of neo-liberalism is simple enough and refers to the "shift from fixed to floating exchange rates, the elimination of capital controls, and the liberalization of trade and investment rules."7 The ideological sense of neo-liberalism and its social and cultural work threatens to dissipate the term into everything and nothing.

Neoliberalism has a varied history depending on its variant as well as its historian. For some, neoliberalism begins with the work of Adam Smith and the classical political economists such as David Ricardo and James Steuart. For others (Foucault and Stuart Hall for example), neoliberalism proper starts in the 1970 s or 80 s. $^{8}$ An important early link between the economic and the cultural is the nexus of free trade and peace. Nineteenth-century economists explicitly argued that the development of free trade could lead to the replacement of mercantilist relations that depended on war by capitalist relations of commerce that depended 
on peace. The same argument in favor of free trade has been consistently voiced with each episode of globalization and neoliberalism. ${ }^{9}$

At the heart of capitalism is the Marxian "free seller of labor-power." As Marx points out, since the laborer "could only dispose of his own person after he had ceased to be attached to the soil and ceased to be the slave, serf, or bondman of another" there is a kernel of truth to the neoliberal utopian fantasy of the individual free entrepreneur engaged in entering contractual relationships most beneficial to himself or herself. But Marx goes on to say that "these new freedmen became sellers of themselves only after they had been robbed of all their own means of production." ${ }^{10}$

Marx begins his definition of a commodity as an "object outside us, a thing that by its properties satisfies human wants of some sort or another," 11 and soon includes labor power as a commodity. The centrality of the commodification of labor to Marx's analysis is underscored by his claim that "the capitalist epoch is ... characterized by this, that labourpower takes in the eyes of the labourer himself the form of a commodity which is his property; his labour consequently becomes wage labour." ${ }^{12}$ It is but a short step from seeing one's labor power as a commodity to seeing oneself as a commodity, which is how the entrepreneur may be understood who sells his or her intellectual power. Neoliberal thought would extend this even further and say that the individual entrepreneur sells not a particular skill but responds to the needs of the market and fashions himself or herself accordingly. Going back to homo economicus, the entrepreneur according to Foucault under neoliberalism is "for himself his own capital, being for himself his own producer, being for himself the source of [his or her] earnings." ${ }^{13}$

For the promoter of neoliberal ideals the entrepreneur-the new homo economicus - always has his or her own means of production: intellectual power and thus intellectual property. An entrepreneur can be defined as "someone who specializes in taking judgmental decisions about the coordination of scarce resources."14 The entrepreneur depends on privileged access to information in order to secure an advantage in a financial transaction. Few people are exempt from the seduction of seeing themselves as intelligent, savvy, individuals ready to become highrolling wheelers and dealers if only government would get out of the way. 


\section{From Community to the Individual Consumer}

The neoliberal notion of democracy prefers consumers over citizens, shopping malls over communities. ${ }^{15}$ Capitalism, in general and neoliberalism in particular, prefers the public to be spectators rather than engaged citizens. In a 1996 essay "Consent without Consent," Noam Chomsky concisely traces the history of the desire and attempts to keep the public disengaged in the US from the founding fathers to contemporary times. Over the centuries, two tools have been used to keep the public at bay: trade treaties that favor the already wealthy and corporations, and propaganda by the wealthy and corporations (by the mid 1990s over $\$ 1$ trillion was being spent annually on marketing, one-sixth of the GDP) ${ }^{16}$

David Harvey's analysis reveals that a major component of the propaganda undertaken by the wealthy pits individuals against regressive and oppressive government.

By capturing ideals of individual freedom and turning them against the interventionist and regulatory practices of the state capitalist class interests could hope to protect and even restore their position. Neoliberalism was well suited to this ideological task. But it had to be backed up by a practical strategy that emphasized the liberty of consumer choice, not only with respect to particular products but also with respect to lifestyles, modes of expression, and a wide range of cultural practices. Neoliberalization required both politically and economically the construction of a neoliberal market-based populist culture of differentiated consumerism and individual libertarianism." 17

Harvey's larger thesis is that a focus on the individual is counter-productive to effective social cohesion and mobilization; neoliberalism is at its best when it promotes an emphasis on individual freedom which comes at the price of class and group interests. New York City in the 1970s and 1980 s is a good case in point. In an ideal neoliberal labor market,

the individualized and relatively powerless worker ... confronts a labour market in which only short-term contracts are offered on a customized basis. Security of tenure becomes a thing of the past ... A 'personal responsibility system' ... is 
substituted for social protections (pensions, health care, protections against injury) that were formerly an obligation of employers and the state. Individuals buy products in the markets that sell social protections instead. Individual security is therefore a matter of individual choice tied to the affordability of financial products embedded in risky financial markets. ${ }^{18}$

\section{The Market is All}

The contemporary deification of the market would have surprised the patron saint of neoliberalist thought, Adam Smith, whose warnings about the dire consequences of the completely unfettered market are conveniently ignored. The cultural effects of such an attitude is readily visible in the dictum that the government is the problem and privatization is the answer. No formerly public sphere is considered out of bounds for corporatization including healthcare and education. It is surely not coincidental that the rise of for-profit schools has come at the expense of reduced funding for community colleges and public universities. A recent social and political furor over the provision of insurer-paid contraception in the US serves to underscore the transformation of neoliberalism from its roots as primarily an economic philosophy to the major worldview that it has become today.

In late February, 2012 conservative talk-show host Rush Limbaugh called a woman a "slut" for testifying on behalf of a new law that will provide insurer-paid contraception to women. Limbaugh has made any number of misogynistic comments before, but three factors make this incident especially noteworthy: one, he continued his personal attacks on Sandra Fluke, the Georgetown University Law Center law student over the next few days; two, Limbaugh has increasingly come to be seen as an influential broker in the Republican party; and three, a leading Republican contender for the Republican nomination for the Presidential candidate, Rick Santorum, attacked contraception a few months earlier as a practice that leads to "unnatural" acts.

Santorum had given an interview to CaffeinatedThoughts.com on October 19, 2010 during which he held forth on the dangers of contraception: 
One of the things I will talk about that no president has talked about is, I think, the dangers of contraceptives in this country. The whole sexual libertine idea. Many in the Christian faith have said, “Contraception's okay." It's not okay. It's a license to do things in the sexual realm that is counter to how things are supposed to be.

And, a few days before his attack on Sandra Fluke, Rush Limbaugh had endorsed Santorum's position calling it exactly right.

A brief timeline might help to contextualize the controversy that played itself out over social media and the news networks. On January 20, 2012 the Obama administration announced that under the Affordable Healthcare Act a new provision would come into effect in August of 2012 providing women free contraceptives. Religious-affiliated employers such as hospitals, schools, and charities would have an additional year to work out the logistics; churches and other houses of worship would be exempt from the requirement. Republican politicians, conservative commentators, and some Catholic religious leaders decried the measure as an attack on religious freedom. The Obama administration responded with a compromise on February 10, 2012:

Under the rule, women will still have access to free preventive care that includes contraceptive services-no matter where they work. So that core principle remains. But if a woman's employer is a charity or a hospital that has a religious objection to providing contraceptive services as part of their health plan, the insurance company-not the hospital, not the charity-will be required to reach out and offer the woman contraceptive care free of charge, without co-pays and without hassles. ${ }^{19}$

A few days later, February 16, 2012, Representative Darell Issa (R-CA) organized a House Oversight panel on the new contraception rule that excluded women. The Democrat committee members who had fought for women to be included on the panel and were denied by Issa held another committee hearing the following week to which women were invited, including Sandra Fluke, the student whom Issa had prevented 
from speaking. It is with the testimony of Georgetown University Law student Sandra Fluke that Rush Limbaugh re-enters the fray.

Were we to leave the contraception "debate" at this point it would serve as another instance of the resurgent culture wars that the incidents of 9-11 were supposed to have moved us beyond, yet one more episode of the increasingly polarized discourse of US politics. Limbaugh, however, extended his attack and connected morality to economic ideas that have come to be seen as key components of neoliberal thought.

Rush Limbaugh went on to make a proposition to Sandra Fluke. He told her that since she was receiving taxpayer money in the form of subsidized contraception that allows her to engage in sexual activity without the risk of pregnancy, then she should offer the customer, the taxpayer, something in return: she should record her sexual activity and make it publicly available by posting it online. Limbaugh displayed his economic logic on a radio broadcast on March 1, 2012: "So, Ms. Fluke and the rest of you feminazis, here's the deal. If we are going to pay for your contraceptives, and thus pay for you to have sex, we want something for it, and I'll tell you what it is. We want you to post the videos online so we can all watch." 20

However, recasting an issue central to women's health as a question of entrepreneurial activity, a key idea in neoliberal thought, inadvertently reveals a fault line in the cultural work of neoliberalism. Aside from making his sympathetic listeners into voyeuristic purchasers of a prostitute's services (the taxpayer pays Fluke to have sex and receives in turn from Fluke the video), Limbaugh also forces them to shift from offering moral condemnation to being complicit in the triangle of sexual activity. Neoliberal thought has the capacity to reduce all cultural activity to a matter of financial relations.

\section{Critical Economics}

The tide of neoliberal thought seems to have swept away all in its way or, to change metaphors in the case of the US, neoliberalism has defined the agenda of American politics. The center has moved substantially to the right, so much so that the Democrats find themselves more in line with the policy positions of Republicans from two decades earlier. A case in 
point is the Affordable Healthcare Act; the measure is so vilified by the Republicans that they have tried to repeal it over thirty times in the past year. Ironically, the central idea and many of the provisions of the act was first proposed by a Republican think-tank and was supported by major Republican politicians. It is telling that under the AHA patients are still cast in the role of consumers who will freely choose an insurance provider from among others in an exchange.

Not all is bleak though. The austerity measures that have been enacted by neoliberals in several European countries recently, and promoted in the US, have shown to be a failure. Riots in Greece and Italy, continuing high unemployment in Portugal and Spain, and lackluster economic growth in Ireland and England have raised serious doubts about the neoliberal narrative of less social spending, fewer government regulations, and greater labor and financial flexibility as the royal road to economic prosperity. It may be the case that neoliberal policies are driving us toward the narrowing of opportunity and concentration of power that Acemoglu and Robinson offer in their analysis Why Nations Fail (2012). Nations that fail tend to make it easier for elites to extract wealth from a country; nations that are inclusive in their political institutions, and that open economic and governing opportunities to as many as possible succeed. According to them:

Countries such as Great Britain and the United States became rich because their citizens overthrew the elites who controlled power and created a society where political rights were much more broadly distributed, where the government was accountable and responsive to citizens, and where the great mass of people could take advantage of economic opportunities. ${ }^{21}$

It may be that Acemoglu and Robinson overstate the importance of political institutions over economic policies but there are emergent signs, however, of new ways of thinking about economics and government.

A number of groups have recently started producing work centered around the concept of New Economics. The New Economics Institute, On the Commons, the US solidarity Economy Network, and the Capital Institute, among others, have begun to research and promote policies that 
"create a fair economy, a clean environment and a strong democracy." 22 A number of grassroots organizations are looking to start discussions that bring together climate, sustainability, and labor issues. Some groups have recommended that measures other than the GDP or the health of the stock market be used in pursuit of policy planning, i.e., metrics other than those that measure the flow of capital.

Alternative measurements have long been used by the UN, which includes gross national income per capita as only one of four indicators in its Human Development Index (life expectancy at birth, mean years of schooling, and expected years of schooling are the other three). A group centered around the work of economist and philosopher Amartya Sen (also one of the developers of the Human Development Index) has focused on a conception of the standard of living as the freedom to achieve well-being in terms of people's capabilities. According to the capability approach, not only are opportunities important but so are the conditions that make the opportunities realizable. Although Sen himself has shied away from providing a list of capabilities, preferring to leave it to particular communities at particular times, others have elaborated capability based on participation, freedom from domination, and justice.

The combination of failed austerity measures, an understanding of the importance of inclusive political and economic institutions, and the research and advocacy of alternate ways of understanding and measuring success may be of some aid at the brink.

\section{Overcoming the Wrath of Neoliberalism}

"Neo-liberal discourse is not like others," warns the French sociologist and philosopher Pierre Bourdieu. "Like psychiatric discourse in the asylum, as described by Erving Goffman," comments Bourdieu, "it is a 'strong discourse' which is so strong and so hard to fight because it has behind it all the powers of a world of power relations which it helps to make as it is, in particular by orienting the economic choices of those who dominate economic relations and so adding its own specifically symbolic-force to those power relations." ${ }^{23}$ The essays in the first section of this book, "Race, Violence, and Politics," demonstrate Bourdieu's point 
well but also reveal some of the ways in which neoliberalism intersects with racism, devastation of the environment, and police violence.

In "Neoliberalism and Violent Appearances," Paul A. Passavant argues that under neoliberalism "disciplinary power has become weaker, and that control technologies functioning through communication systems are displacing patterns of order premised on disciplinary power." Under the conditions of what he terms "communicative capitalism," "an experience of infinite communicative possibilities and the communicative equivalence of all opinion indicate the loss of modernity's meta-narrative of gradual progress realizing norms of human dignity and democracy." Within these conditions, the "First Amendment jurisprudence has become reshaped in a neoliberal form that allows a demonstration to be zoned to a location far from (or invisible to) what one seeks to protest." Similarly, "repeated acts of police using excessive violence against demonstrators in news reports or captured on YouTube videos do not compel normative outrage or changes in police practices the way they did in the 1960s." As such, communication of police violence within neoliberal society and culture does not inspire a strong sense of public outrage.

"The Turn to Punishment: Racism, Domination, and the Neoliberal Era" by Noah De Lissovoy is an inquiry into the "meaning and logic of the turn to punishment within the context of neoliberalism, and the hardening that this turn marks in the cultures of law enforcement, education, and public discourse." De Lissovoy maintains that the "prevailing political-economic and biopolitical accounts" of this conjuncture "should be enlarged to include a phenomenology of domination itself and its complex dialectics of subjection and resistance." Drawing from the historical Black radical tradition, De Lissovoy argues that "in order to adequately make sense of the turn to punishment, and neoliberalism more broadly, we need to foreground the fact and logic of racism." For him, the legacy of racism is "the secret determinant of the carceral turn in neoliberal culture." Consequently, for De Lissovoy, neoliberal society's carceral turn is "a specific and exceptional conjuncture within" the "broader history and logic of domination.”

In "Neoliberalism, Environmentality and the Specter of Sajinda Khan," Robert P. Marzec explores some of the connections between neoliberalism and environmentalism - two areas that have developed 
relatively autonomously over the past fifty years. According to Marzac, "although many environmentalists have made the connection between neoliberal economic policies and the destruction of specific environments," neoliberals "have proceeded apace without concerning themselves too much with ecological concerns." However, the advent of scientific evidence of global warming may mark "the coming of the end of neoliberalism, a decisively different change in its essential character." For Marzec, this "change can be defined as a new idea of ecological necessity or eco-empiricism, one that has begun to draw attention away from economic production and development towards matters of national security." This eco-empiricism, argues Marzec, should "be understood as a new type of ontological machine, one energized by state, military, and scientific authorities buttressing their activities on the futural event of environmental catastrophe." In turn, this "environmentality" "is the force now confronting the neoliberal State, and it is beginning to transform this reigning state formation into a new, more complex political apparatus"-one Marzec terms "the Accidental State."

Jennifer Wingard's "Rhetorical Assemblages: Scales of Neoliberal Ideology" reveals and aims to disrupt the "othering" power of neoliberal rhetoric through an examination of two specific sites of othering: post-Hurricane Ike Houston and the US national anti-immigration campaign of 2004. According to Wingard, both of these events use "othering" to "define a community during a time of perceived jeopardy." In addition, both of these sites "produce said jeopardy," argues Wingard, by "occlud[ing] the material conditions of neoliberal culture." Her aim is to "create a counter narrative wherein the other can be seen not as a tool of neoliberal culture, but rather a symptom from which we can begin to analyze its material conditions and rhetorical deployments."

The final essay in this section, "Neoliberalism, Autoimmunity and Democracy: Derrida and the Neoliberal Ethos" by Zahi Zalloua argues that the neoliberal ethos both dominates the public sphere and structures our very mode of being. In addition, it has "thoroughly naturalized itself-appearing to its defenders and dissenters alike as the only game in town." Some, like Žižek, blame postmodernism "for fostering an intellectual climate wholly compatible with neoliberalism.” Furthermore, Žižek implicates the philosophy of Derrida in the rise of neoliberal. Zalloua, 
however, challenges Žižek's reading of Derrida by showing how he offers a powerful critique of the neoliberal ethos in his reflections on the autoimmunity of democracy.

The next group of essays continues to examine the damage wrought by neoliberalism though focuses more on the changes it has brought regarding concepts of the self and agency. In addition, whereas the first group of essays dealt more broadly with society and the environment, the second group contends more specifically with the intersections of popular culture, literary studies, and publishing with neoliberalism.

According to Jodi Dean, "neoliberalism reconfigures elements of multiple discourses" including "frontier myths of heroic individuals, new media celebrations of fast and fluid networks, fantasies of free markets, misplaced critiques of collective ownership and government regulation, as well as confusions between the economic concept of competition and competition understood as a rivalry or contest." In her essay, "Complexity as Capture: Neoliberalism and the Loop of Drive," however, two additional components of the neoliberal atmosphere-reflexivity and complexity-are examined through the psychoanalytic category of "drive." Her aim is "to illuminate some of the specific ways neoliberalism captures its subjects and thus formats the terrain of contemporary class struggle.

In "Neoliberalism, Risk, and Uncertainty in the Video Game," Andrew Baerg argues that "the contemporary video game naturalizes a neoliberal decision-making process that is increasingly characterized by an approach grounded in risk and risk management." As such, Baerg's essay reveals one of the ways in which the discourse of neoliberalism has become such a strong one. Video games are one of the most globally popular forms of entertainment, and to regard them as a means of disseminating and promoting a neoliberal approach to risk is particularly discouraging to opponents of neoliberalism.

"Neoliberalism in Publishing: A Prolegomenon" by Jeffrey R. Di Leo argues that the ascent of neoliberalism in the publishing world is one of a gradual intensification of market considerations over aesthetic or scholarly ones-a story that holds to varying degrees both within the corporate publishing industry and now within the university and small press publishing world. However, it is not one that has been widely 
considered - though it needs to be. The aim of his chapter is to provide a broad overview of neoliberalism in publishing and to encourage others to consider the connections between the publishing world and the legacies of neoliberalism. "The hope," writes Di Leo, "is that an understanding of the destructive powers of neoliberalism within the publishing world will empower and encourage authors and scholars to work to disrupt its further development and continued ascent through acts of resistance."

Christopher Breu's "The Post-Political Turn: Theory in the Neoliberal Academy" examines the impact of neoliberalism on the academy over the past the last thirty years. For Breu, although this impact "has taken a number of different forms and provoked a number of different responses," he focuses on one particular aspect: the expansion and contraction of politicized scholarship in the academy. In particular, he tracks theory for its politicization of culture and language in the 1990s to its current emerging depoliticization. However, rather than worrying about the current depoliticizing trend, Breu offers in its place a hopeful message of the emergence of a "counter-trend of newly materialist scholarship that takes up the political engagements of the long nineties, but in a more materialist direction that holds the potential to challenge the dematerializing ideology of neoliberalism itself, with its emphasis on financialization and what Michael Hardt and Antonio Negri term "biopolitical" or so-called "immaterial" labor (i.e. affect, service, and intellectual labor)."

The final essay in this collection, "Neoliberalism, Post-Scarcity, and the Entrepreneurial Self" by Uppinder Mehan, problematizes the selfconstructed by neoliberalism by reflecting on the gap between the neoliberal ideal of the autonomous entrepreneur and the realities of the creatures who live under neoliberalism. Drawing on science fiction, Mehan speculates as to qualitative differences of life after "singularity," that is, in the words of Ray Kurzweil, "a future period during which the pace of technological change will be so rapid, its impact so deep, that human life will be irreversibly transformed." ${ }^{24}$ For Mehan, the post-singularity world, which is also a time where we will have all but certainly finally "moved into a post-scarcity world," is one where we may finally be able to fully "realize the self promised by neoliberal rhetoric: an autonomous, entrepreneurial self, free to make rational choices about every aspect of life." 
Together, the ten essays in this collection reveal the pervasiveness, destructiveness, and dominance of neoliberalism within American society and culture. They also suggest points of resistance to an ideology wherein, to borrow Henry Giroux's comment from our epigraph, "everything either is for sale or is plundered for profit." The first step in fighting neoliberalism is to make it visible. By discussing various inroads that it has made into political, popular, and literary culture, we are taking this first step and joining a global resistance that works against neoliberalism by revealing the variety of ways in which it dominates and destroys various dimensions of our social and cultural life.

\section{Works Cited}

Acemoglu, Daron and James A. Robinson. Why Nations Fail: The Origins of Power, Prosperity, and Poverty. New York: Crown Publishing, 2012.

Bourdieu, Pierre. Acts of Resistance: Against the New Myths of Our Time. Trans. Richard Nice. Cambridge: Polity Press, 2000.

Casson, Mark. The Entrepreneur: An Economic Theory. Northampton, MA: Edward Elgar Publishing, Inc., 1982.

Cavanaugh, John and Robin Broad. "It's the New Economy, Stupid." The Nation. November 28, 2012. http://www.thenation.com/article/171502/ its-new-economy-stupid\#axzz2cQW24zrB

Chomsky, Noam. Profit Over People: Neoliberalism and Global Order. New York: Seven Stories Press, 1999.

Drum, Kevin. "Why Screwing Unions Screws the Entire Middle Class.” Mother Jones. March/April 2011. http://www.motherjones.com/politics/2011/02/ income-inequality-labor-union-decline

Foucault, Michel. The Birth of Biopolitics: Lectures at the College de France, 1978-79. New York: Palgrave Macmillan, 2008.

Harvey, David. A Brief History of Neoliberalism. Oxford: Oxford UP, 2005.

Kiely, Ray. The New Political Economy of Development. New York: Palgrave Macmillan, 2007.

Kurzweil, Ray. The Singularity is Near. New York: Viking, 2005.

Lakoff, George. Moral Politics: How Liberals and Conservatives Think. Chicago, IL: University of Chicago Press, 2002. 
Marx, Karl. Capital: A Critique of Political Economy. New York: Random House, 1906.

McChesney, Robert W. "Introduction.” In Profit Over People: Neoliberalism and Global Order by Noam Chomsky. New York: Seven Stories Press, 1999.

McGuigan, Jim. “Creative Labour, Cultural Work and Individualization.” International Journal of Cultural Policy 16.3 (August 2010).

Powell, Lewis F. "Confidential Memorandum: Attack of American Free Enterprise System.” August 23, 1971. http://reclaimdemocracy.org/corporate accountability/powell_memo_lewis.html

\section{Notes}

1. Lewis F. Powell, "Confidential Memorandum: Attack of American Free Enterprise System.” August 23, 1971. http://reclaimdemocracy.org/ corporate_accountability/powell_memo_lewis.html

2. Ibid.

3. Ibid.

4. Kevin Drum, "Why Screwing Unions Screws the Entire Middle Class." Mother Jones. March/April 2011. http://www.motherjones.com/ politics/2011/02/income-inequality-labor-union-decline

5. See George Lakoff, Moral Politics: How Liberals and Conservatives Think (Chicago, IL: University of Chicago Press, 2002).

6. Jim McGuigan, "Creative labour, cultural work and individualization," International Journal of Cultural Policy 16.3 (August 2010): 333.

7. Ray Kiely, The New Political Economy of Development (New York: Palgrave Macmillan, 2007), p. 9.

8. See Michel Foucault, The Birth of Biopolitics: Lectures at the College de France, 1978-79 (New York: Palgrave Macmillan, 2008).

9. Ray Kiely, The New Political Economy of Development, p. 33.

10. Karl Marx, Capital: A Critique of Political Economy (New York: Random House, 1906), p. 786.

11. Ibid, p. 41 .

12. Ibid, p. 189n.

13. Michel Foucault, The Birth of Biopolitics, p. 226.

14. Mark Casson, The Entrepreneur: An Economic Theory (Northampton, MA: Edward Elgar Publishing, Inc., 1982), p. 20. 
15. Robert W. McChesney, “Introduction.” Profit Over People: Neoliberalism and Global Order by Noam Chomsky. (New York: Seven Stories Press, 1999), p. 11.

16. Noam Chomsky, Profit Over People: Neoliberalism and Global Order (New York: Seven Stories Press, 1999), p. 58.

17. David Harvey, A Brief History of Neoliberalism (Oxford: Oxford University Press, 2005), p. 42.

18. Ibid., p. 168.

19. The White House, Office of the Press Secretary, February 10, 2012, Remarks by the President on Preventive Care. http://www.whitehouse.gov/ the-press-office/2012/02/10/remarks-president-preventive-care

20. http://mediamatters.org/blog/201203010012\#wednesday

21. Acemoglu, Daron and James A. Robinson, Why Nations Fail: The Origins of Power, Prosperity, and Poverty (New York: Crown Publishing, 2012), p. 15.

22. John Cavanaugh and Robin Broad, "It's the New Economy, Stupid," The Nation. November 28, 2012. http://www.thenation.com/article/171502/ its-new-economy-stupid\#axzz2cQW24zrB

23. Pierre Bourdieu, Acts of Resistance: Against the New Myths of Our Time, Trans. Richard Nice (Cambridge: Polity Press, 2000), p. 95.

24. Ray Kurzweil, The Singularity is Near (New York: Viking, 2005), p. 7. 
Race, Violence, and Politics 
Chapter 1

\title{
Neoliberalism and Violent Appearances
}

\author{
Paul A. Passavant
}

Forty years ago, civil rights activists who marched to protest racial segregation and to demonstrate in favor of the right to vote were met by police and mob violence. Acts of violence by police officers shocked the nation's conscience, creating pressure for stronger enforcement of not only the Constitution's Fourteenth and Fifteenth Amendments, but of the First Amendment as well. More recently, demonstrations at events such as the World Trade Organization (WTO) Meetings hosted by Seattle in 1999, the anti-war protests in New York City in 2003, the Republican National Convention (RNC) in 2004, demonstrations at the 2009 G-20 meetings in Pittsburgh, and the Occupy! movement, have been met by intimidating and torturous treatment by police. There have been internal reviews of police practices, reviews of police practices by civilian review boards, reports issued by civil liberties organizations, police departments have been sued, and there have been monetary settlements. Yet intimidating and violent policing of peaceful demonstrators and innocent bystanders continues to occur (and videos of these incidents circulate widely on YouTube).

This chapter argues that with contemporary society's reflexive understanding of infinite communicative possibilities and the communicative equivalence of all opinion, evidence of institutional efforts to prevent people from exercising their rights of speech and assembly simply adds one more frame to a universe of infinite communicative possibility. The communicative equivalence of all opinion indicates the loss of a metanarrative of commitment to improving the material recognition of human 
dignity or democratic strength. This "decline of symbolic efficiency," to use Slavoj Žižek's terminology, indicates the weakened hold upon us of the horizon to which non-violent civil disobedience must be oriented. ${ }^{1}$ It also indicates a weakened sense that police brutality is wrong, as it no longer shocks the public's conscience. It merely appears. Some are not shocked by its appearance, responding with a cynical, bemused, or slightly bored, "whatever." Others enjoy it.

\section{Modernity and Subjectivity}

As feudalism ended and modern nation states began to displace feudalism, a number of transformations occurred. In addition to the emergence of a conception of the public, and a sensibility of "society," there was a transformation in subjectivity. The social theorist Norbert Elias describes this joint process of social transformation and subjective transformation in The Civilizing Process. With the end of the high status of knights, as knights were brought in from the outside, they had to learn new forms of self-control. Seated at a general table before the eyes of many, they were reduced in stature from the hierarchies of honor and battlefield accomplishments to simple equality vis à vis each other, and non-knights (such as the emerging bourgeoisie). All were equal before the watchful eyes of the king at the table. This contrasts with aristocratic society. Aristocrats feel no shame before the eyes of their servants because servants are unequal to them - the latter do not register before the former as worthy of the kind of concern that would result in a sense of shame. According to Elias, the change in subjectivity (emerging consciousness of how one appears before the eyes of others and engaging in forms of self-discipline as one internalizes the gaze of "everyone") corresponds to a deeper social transformation: the creation of the modern state and modern society.

Elias explores the transformation in subjectivity through manners manuals published in the Middle Ages and early modern era. He describes a conversation between the poet Delille and Abbé Cosson, a Professor of Belles Lettres at the Collège Mazarin, in which Abbé Cosson related his recent dinner with some court people at Versailles. Delille asserts to Abbé Cosson that he undoubtedly "perpetrated a hundred incongruities,” which perturbed Abbé Cosson greatly, leading 
Abbé Cosson to insist that he "did everything in the same way as everyone else." Delille suspects otherwise, and so asks him what he did with his napkin, how he ate his soup, how he ate his bread, and so forth. In each response, Abbé Cosson begins by stating that he "did the same as everyone else," but Delille lets him know that in fact he did not, though he failed to be self-conscious about his shortcomings. No one fixes his serviette into a buttonhole, one keeps it on his knees. No one uses a fork to eat soup. One breaks bread, one does not cut it into little pieces with a knife. Finally, how did Abbé Cosson drink his coffee at the conclusion of the meal? "Like everyone, to be sure. It was boiling hot, so I poured it little by little from my cup into my saucer," he replies. "Well," says Delille, "you certainly did not drink it like everyone else. Everyone drinks coffee from the cup, never from the saucer...."

Delille's questions for Abbé Cosson, and Abbé Cosson's responses, pivot around what "everyone" does - what is the norm for using a napkin? For eating one's soup? For eating one's bread or drinking one's coffee? Moreover, Delille helps Abbé Cosson to see himself through the eyes of "everyone," encouraging him to regulate his behavior in front of others in accordance with the norms of what "everyone" does and what everyone expects others to do. Delille is facilitating Abbé Cosson's internalization of the gaze of "everyone" when he is in public. In sum, with the transformation from feudalism to modern society, with the emergence of "public" and "private" spaces, there is a corresponding transformation of subjectivity as subjects come to internalize the normative gaze of "everyone," or, adjusting social theorist George Herbert Mead slightly, subjects learn to internalize the normative gaze of a generalized other. ${ }^{3}$

Michel Foucault's Discipline and Punish describes the institutional processes whereby the normative gaze of the other-a prison guard, a factory manager, a teacher, a military commander, or the norms of the human sciences and the helping professions-becomes progressively installed within subjects. Discipline bears on the "soul." According to Foucault, punishment in disciplinary society "acts in depth on the heart,

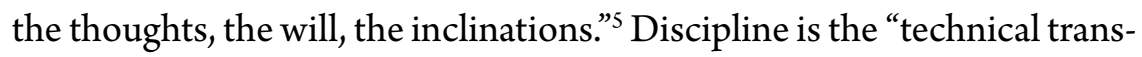
formation of individuals." 6 Through repeated exercises and observation, the individual gains useful habits. Discipline is a set of double relations. It produces docility, on the one hand, and increased utility or capabilities, 
on the other. ${ }^{7}$ Discipline creates a common social plane-it fixes norms for a given population and creates a "social body." Discipline also measures and differentiates individuals with respect to this social norm. ${ }^{8}$ In other words, there is individualization, but in relation to a broader conception of the "social." The shift away from sovereign vengeance with the Enlightenment and modernity is therefore described by Foucault as a shift to the "defence of society." According to Foucault, the historical transformation of modernity is one where the disciplines "spread throughout the whole social body." ${ }^{10}$

Foucault reminds us that the "Enlightenment', which discovered the liberties, also invented the disciplines." 11 For Foucault, disciplinary power is the "dark side" of a "formally egalitarian juridical framework." 12 We should recall, however, that the generalization of disciplinary power is coeval with the emergence of parliamentary democracy. In contrast with Foucault's exposition in Discipline and Punish, I explore here a different, more positive aspect of this co-relation between discipline and the concept of equal human rights: discipline's relation to continuous improvement with respect to humanitarian purposes and the purposes of self-government.

Foucault states that the "ideal point of penalty today would be an indefinite discipline: an interrogation without end ... a procedure that would be at the same time the permanent measure of a gap in relation to an inaccessible norm and the asymptotic movement that strives to meet in infinity." ${ }^{13}$ To be sure, Foucault means this critically. A literal interrogation without end would be torturous. Yet, isn't this the very horizon of the Enlightenment? The Enlightenment project and the project of democracy are a constant interrogation of present circumstances in relation to norms of human dignity, democracy, and justice. In other words, the Enlightenment project is one that grapples with a "lasting hiatus" or "incommensurability" between norm and the reality of human behaviors, between a rule and its application. ${ }^{14}$ This incommensurability is also the horizon of Marxism. Marxism exploits the gap between norm and reality: it is the space of critique.

Marxism is a philosophy and a revolutionary praxis of progress. As Étienne Balibar argues, the "question of historicity is one of the most open questions of the present time." In addition to moralizing religious 
discourses, there seem to be two dominant tendencies today: the return of a Hobbesian "'war of each against all,' which requires the creation of an external power of constraint." We could call this first option authoritarian neoliberalism, which encloses so much thinking and political action in the United States since the early 1970s. The second option is "to plunge historicity into the element of nature (which seems to be an emergent tendency in the current revival of vitalist philosophies)." ${ }^{15}$ We could broadly designate this second option as one that subsumes politics and critique to biopolitics and affect, keeping analysis and advocacy occupied with ontological or immanent concerns.

The third possibility, however, is to think "for and against Marx," to "think the change of historical institutions ... the 'change of change' ... on the basis of the relations of force which are immanent in them in a way that is not merely retrospective but, above all, prospective," to think the articulation of a "problematic of modes of production," and a "problematic of the mode of subjection." As opposed to models of linear evolution, "we would have to liberate the ... notion which gradually took shape within his writings: the notion of tendency and its internal contradiction." ${ }^{16}$ Marx, according to Balibar, is poised between philosophy and politics, between "theoretical knowledge of the material conditions which constitute the present," and "action in the present," between "liberatory, egalitarian insurrection," and "science." ${ }^{17}$ What stands in the way of such prospective, liberatory, and egalitarian thinking and action? Among other challenges lies one particularly deep barrier. Today, we are experiencing "the decay or 'the decadence' of the idea of progress." 18

In sum, the transformation from feudalism to modernity correlates with a transformation of subjectivity, as subjects are encouraged to understand themselves and their relation to society from the perspective of social norms that demand a certain manner of being in public. Foucault's discussion of disciplinary power describes how this process of subjectification was institutionally disseminated, and how this process of subjectification was at the same related to what came to be referred to as "the social." Foucault suggests in Discipline and Punish a kind of torturousness to the perpetual interrogation of the present with respect to a norm as the gap between present and norm can never be closed. 
Although it is not hard to think of examples of "Foucauldian torturousness," I contend this irresolvable gap between norm and actuality constitutes the possibility for critique. ${ }^{19}$ Marx, for example, exploits this gap in The Communist Manifesto when he argues that under capitalist conditions, the representative state represents the power of capitalism. Thus the first step to revolution is "to raise the position of the proletariat to the position of the ruling class to win the battle of democracy." ${ }^{20}$ This gap between norms of justice or democracy and present circumstances is where we can find the possibility of liberatory and egalitarian futurity, and of progress: there are these possibilities when there are acts of decision and critique occurring in this gap of discontinuity, inspired by and faithful to those norms, while refusing to be submerged into what merely is, by seeking to improve upon aspects of our existence that measure up poorly to norms of human dignity, democratic egalitarianism, and justice. Today, however, we are experiencing the decay of the orientations to futurity that underwrote, gave credit to, and invested the meaning of reform and revolution. We are experiencing the decay of disciplinary power, the normative gaze of the generalized other, and the faith in a better future. According to some, we are experiencing the "death of the social." 21

\section{Societies of Control and Communicative Capitalism}

According to Michael Hardt and Antonio Negri, today, the disciplinary institutions of civil society are everywhere in crisis and are withering. This means not only that these institutions cannot mediate between social forces and the state, or transmit grievance upwards towards the state for resolution, but that these institutions cannot produce legitimacy for state policies in society. Because they are withering, they fail to shape subjectivities in the way that these institutions once did. ${ }^{22}$

Hardt and Negri find that there has been a transformation from disciplinary society to "societies of control." Civil society's disciplinary institutions have become eviscerated, and control technologies have taken their place. Control technologies operate through new communications technologies and digitalization. DVDs, for example, are encoded so that they will operate on DVD players in one region, but not in others. Control operates through barcodes, RFID chips, digital passcards coding bodies 
to spaces, biometrics, passwords, and surveillance built into the technologies we use in our everyday lives, from mobile phones and hand-held communication devices assuring that we never leave work when we go home or go on vacation, to electronic book readers that control how long we can choose to lend a book to a friend or prevent us from re-selling that book to a used book dealer. ${ }^{23}$

Significantly, these control technologies do not bear on the "soul." One's "soul" remains untouched when one is digitally enclosed. Control technologies do not require subjects to internalize the normative gaze of the generalized other. Regardless of one's good habits, intentions, or purposes, the technology will not allow one to lend a book to a friend for too long or to sell it to a used book dealer if we only "possess" the book in an electronic format. For the exercise of "control," one does not police oneself; one is policed through a code that functions in accordance with its own logic, and irrespective of any self-reflection or training of the subject. Control technologies provide a substitute for disciplinary training.

With the weakening of disciplinary power, and the erosion of disciplined subjectivities, a process of de-subjectification is unleashed. For Hardt and Negri, bodies and minds are now freed to become a biopolitical unity of multiplicities and singularities. This biopolitical unity would be undisciplined, hence ungoverned and ungovernable by sovereign power.

For Hardt and Negri, passage to societies of control has consequences for revolutionary potential and for strategies of revolt. In terms of revolutionary potential, there are advantages to the evisceration of civil society institutions from Hardt's and Negri's perspective. They can no longer manufacture consent the way that they could in Gramsci's day. They have lost their disciplinary grip, and they no longer have the capacity to produce disciplined subjectivities that can be incorporated within the hegemonic bloc. ${ }^{24}$ In terms of strategies, Hardt and Negri reject Antonio Gramsci's strategy of counter-hegemonic struggles through civil society institutions like the media, political parties, or labor unions. Because these institutions are withering, they can no longer channel demands to the state. Nor can advances in popular consciousness become inscribed in state policies because mediating institutions linking social forces to the state have become so weakened. 
Moreover, because these representative institutions are weakened, antagonistic interests cannot be so easily mediated or absorbed by the state. Antagonistic forces confront each other directly. Or, the state withdraws from the task of mediating and re-incorporating antagonistic interests, substituting forceful police functions for a lost capacity to mediate conflict. For Hardt and Negri, President Reagan's firing of air traffic controllers during the PATCO (Professional Air Traffic Controllers Organization) strike, rather than finding a negotiated solution to the labor dispute, is symptomatic of the withering of the mediating role of civil society institutions and a state that has lost the capacity to represent or resolve divergent interests. ${ }^{25}$ The state persists, but, from the perspective of liberal democracy, in a post-legitimacy form.

Hardt draws a connection between the ontological experience of control societies and Giorgio Agamben's concept of "whatever being." According to Hardt, control 'functions on the basis of 'the whatever,' the flexible and mobile performance of contingent identities, and thus its assemblages or institutions are elaborated primarily through repetition and the production of simulacra." ${ }^{27}$ Hardt translated Agamben's Coming Community into English, which is where Agamben develops the idea that the coming community is "whatever being." There, Agamben describes whatever being as singularity exposed "as such." ${ }^{28}$ Whatever being is a "perfect exteriority" of humans experiencing "their own linguistic being - not this or that content of language, but language itself, not this or that true proposition, but the very fact that one speaks." ${ }^{29}$ It is the communication of communicability and the exhibition of mediality as such. ${ }^{30}$ This communication of communicability, this sharing of linguistic experience in itself occurs without presupposition. Communication without presupposition, foundation, or condition of belonging. This is communication without revelation. ${ }^{31}$ It is a communication of ... whatever.

The endless texting our students enjoy, clicking "like" on Facebook, or the YouTube video that gets circulated for a quirky, singular gesture, lead us to realize that content is not what is being communicated. Whether we are talking about a viral video of a UCLA student's screams as he is getting tasered or the techno remix of his screams that can also be accessed on YouTube, whether it is the torture or the funky remix of the torture, they both share the common denominator of communicability. 
We realize that anything can be remixed and recirculated, and we communicate this if we take a cue from the website that assembled the "top" remixes of Howard Dean's 2004 scream that killed his campaign dead in Iowa or the website that has assembled the "top" remixes of Andrew Meyer's "Don't Tase Me, Bro," screams, and post yet another link to the mashup. ${ }^{32}$ Or remix the remix. Whether it is a person screaming because he is being tortured, or a danceable remix of the tortured screams, they all share the common denominator of communicability. ${ }^{33}$

Today, there is the communication of communicability. Television news, for example, invites us to "tell them what we think" by "logging on to our website" or by sending text or twitter messages (which are then read on air or scrolled ceaselessly at the bottom of the screen). Anderson Cooper invites us to blog our immediate reactions to the show in progress (though we are advised to "keep it short" since they don't have time to "read a book"). In addition to valuable marketing data, we give them "content," and "reaction" when we participate in the production of communication. This is the potentially infinite productivity of communication, of communicative capitalism. We are entering a condition of reflexivity without normativity and the experience of the communicative equivalence of all opinion.

What drove this transformation? For Hardt and Negri, as well as for Agamben, transformations in capitalism led to these developments. Hardt and Negri describe a shift from capitalism's Fordist phase of disciplined industrial production on a factory assembly line to a post-Fordist phase. Under conditions of post-Fordism, automation allows for production with fewer workers, making capital less reliant on labor. New communications technologies allow for goods to arrive "just in time," allowing capital to employ workers only when necessary. Production occurs through networks, and computer networks are embedded within production processes. In other words, production is not limited to the enclosures of a factory's walls for an eight-hour workday. By occurring within communications networks, productive activity occurs wherever we happen to be when we get the email, phone call, or text message. Though Verizon says "we never stop working for you," actually it is their communications technologies that have the consequence that we never stop working. 
Today, production is communicative in nature. We live under conditions of "communicative capitalism." ${ }^{44}$ Communicative speculation is no longer confined to a distinct financial sector of the economy. Even "manufacturing" corporations like General Motors now make most of their money not from producing automobiles, but from financial services. ${ }^{35}$ Production comprises the communication of affect, entertainment, code, and the communication of communicativity. We are connected and constantly participating in the neoliberal communicative networks. ${ }^{36}$

There is a double movement to neoliberalism and the emergence of communicative capitalism. On the one hand, neoliberal subjects must become "flexible" and open to whatever. As sociologist Zygmunt Bauman notes, under conditions of neoliberal globalization, the "pressure today is to dismantle the habits of permanent ... regular work." ${ }^{37}$ In this respect, those potentially capable of work have become post-disciplinary in a way that is homologous to the openness to the whatever of viral communicative remixes sharing the common denominator of communicability: both are responsive to whatever.

On the other hand, at the level of a specific job, specialization has become more intense under communicative capitalism. According to media theorist and activist Franco "Bifo" Berardi, while Fordist factory workers were essentially interchangeable, "attorneys, computer technicians and mall vendors all sit in front of the same screen and type on the same keyboards: still, they could never trade places." ${ }^{38}$ This is homologous to the experience created by the increased personalization of digital media. Based on our digital profiles created and stored by the trackable traces of our prior choices, amazon.com can tailor its marketing to us, websites can individualize the appearances of webpages (and their advertising) to us, and Google can personalize "information" to our interest profiles when we use its search engines. ${ }^{39}$ In this way, we are increasingly digitally enclaved and enclosed. (And this, in turn, is homologous to the increased segmentation and segregation of lived geographic space. ${ }^{40}$ ) Subjective experience under neoliberal conditions, and amplified by communicative capitalism, is increasingly narcissistic, enclosed, and selfreferential. Like a market niche.

Berardi explores the psychic costs of the "new economy," finding that depression is "deeply connected to the ideology of self realization 
and the happiness imperative." ${ }^{41}$ With our personal communication devices, we are plugged into digital networks that function at the speed of light, and we are constantly on call for when the production process needs us. Depression, then, can be a defense mechanism of the organism against this excessive flow that overwhelms what a human can bear, as it detaches from the network for self-preservation. ${ }^{42}$ Berardi also suggests that depression is linked to the consequences of neoliberalism that "many are called but only a few are chosen," yet neoliberalism cannot acknowledge the necessity of widespread entrepreneurial failure without putting the fundamentals of the system itself in ideological jeopardy. ${ }^{43}$ The popularity of reality television in the United States, however, trades on viewers who enjoy watching the prevalence of competitive failure, from The Apprentice or Celebrity Apprentice (You're Fired!) to the extended period of time American Idol devotes to showing those who try out for the singing competition and yet who clearly cannot sing whatsoever so the viewer can laugh at them and then enjoy the pleasure of watching the judges laughing at them as well. ${ }^{44}$ Therefore, it seems more accurate to say that there is affective pleasure in enjoying neoliberalism's failures as long as it isn't me, though subjects may experience the stress that it could be me, and this can manifest itself in anxiety, insecurity, or the depression Berardi documents.

Or anger and resentment. Some reasonably do not want to become more "flexible," or open to "whatever." Some are angry at becoming "redundant" and "unnecessary" from the perspective of global capital. With neoliberalism's embrace of competition, this means that inequality is fundamental (some are winners, others are losers; some have more, others less; someone got the job, others did not), as opposed to the Enlightenment's orientation to equality. For some, this is appealing. They are attached to inequality and enjoy it. They enjoy their anger with the Enlightenment's equal rights or with unromantic modernity's orientation to social democracy and cultivate it. Under post-disciplinary conditions of communicative capitalism, one is encouraged not to discipline oneself, but to express oneself. ${ }^{45}$ So while some open to whatever are clicking "like," others are attached to expressing their anger, which they do by watching Fox, by reading the New York Post, or by logging onto breitbart. com. Or worse. 
Whatever being, then, is shadowed by a doppelganger that shares a post-disciplinary responsiveness to the injunction of expression, as well as a post-truth relation to new media. Suspicious of professional norms and affectively incited, whatever being's doppelganger calculates that if general social norms are lacking, and if everyone is biased, then my affective attachments are as good as anyone else's. Who's to say they are wrong or bad? So if I enjoy this, if I am affectively attached to it, then I should express this and no one has grounds to criticize me. Whatever being does not check these tendencies of its doppelganger, it accommodates them because it concedes the condition of interpretive multiplicity without normativity that its doppelganger seeks to exploit. To emphasize: critique has become displaced. ${ }^{46}$ What we have instead of antagonism is either an openness to whatever or affective expression that appears in a narcissistic niche of communicative capitalism.

Let's bring this back to the field of crime and punishment-the centerpiece of Discipline and Punish. The criminologist David Garland describes how, in the late 1960s, public policy relating to crime and punishment was not politicized. The politicians of both political parties in the United States were content to defer to the experts, and the experts sought to implement the "correctionalist" policies that were the subject matter of Foucault's scholarship published in the mid-1970s. Correctionalism was critiqued by radical criminologists for not working - a critique that resonated with fringe rightwing politicians and the position papers of rightwing think tanks. In the late 1960s, correctionalism was hegemonic. Beginning in the 1970s, however, its institutional structure collapsed with devastating speed, "like a house of cards." ${ }^{37}$ As Garland puts it, no one "could have predicted such an outcome, and no one did." ${ }^{48}$ He finds the demise of correctionalism and its rehabilitative ethos not to be driven by "reasoned criticism" and "adjustment to negative findings," but a "collapse of faith" that was "something akin to a stockmarket crash." 4

Foucault notes that neoliberalism is hostile to planning or state intervention to correct anti-social developments because of its distrust of knowledge: intervention is pointless because of spontaneous order, and it is dangerous because of the limits of knowledge-by intervening, you can make things worse because you may not know what you think you know. ${ }^{50}$ Under the current neoliberal formation in the field of crime and 
punishment, with the demise of professional credibility or faith in the use of social science knowledge in public policy making, we do not merely have pro-market advocacy, which Foucault attributes to neoliberalism, or an actuarial focus on risks of crime or crime statistics. ${ }^{51}$ Additionally, the United States experience with neoliberalism indicates an affective or expressive dimension to state policies regarding crime and punishment. That is, with the politicization of criminal justice policies through rightwing populism, politicians seek to express moral outrage by voting for ever-more severe criminal punishments. With the demise of credible knowledge, instead of the control of passion in the interests of self-government, state policies now express affect or passion, such as outrage at evil. In this vein, conservative legal scholar Walter Berns describes one of the benefits of capital punishment in 1979 as "the pleasure arising from ... exacting revenge." ${ }^{2}$ Symbolically, criminological and penal practices are now forms of government marking certain populations as undeserving of social inclusion, equality, or human dignity. ${ }^{53}$

The rehabilitative ethos had been supported by a social mentality of mutual trust and social solidarity. ${ }^{54}$ Today, the prison is correctional only in name as its functionality is to contain evil monsters indefinitely as an extension of "zero-tolerance" and preventative policing crime mentalities. These practices are completely antagonistic to a governmentality of social solidarity, and there is no need for knowledge since radical evil defies rational comprehension and explanation. ${ }^{55}$ What have been the consequences of this collapse of faith in criminological expertise? An increase of those incarcerated in the United States by a factor of over 500 percent, which has produced a devastating impact on communities, families, the human rights of those incarcerated, and state and federal budgets. How should we describe this "collapse of faith" that Garland likens to a "stockmarket crash"? It is the collapse of the horizon of social democracy, of the Enlightenment, and of modernity - the collapse of faith in a meta-narrative of progress and social improvement.

\section{Norms and Futurity}

We can compare planned protests by the civil rights movement in the 1960s seeking enforcement of the Fourteenth and Fifteenth 
Amendments, as well as non-discriminatory treatment, to more recent demonstrations, in terms of public reaction to police violence against the demonstrators. The civil rights movement received sustenance from a normative gaze of the generalized other, and faith in future progress. Although repetitive police violence against contemporary left-oriented demonstrations could be understood as a sign of state impotence in terms of garnering liberal democratic legitimacy for its policies, it is also a sign of a weakening in the norm that the state should not treat its people like "the enemy," or that it is not "criminal" to exercise democratic rights. ${ }^{56}$ We cannot count on a collective social judgment based on the norm that police violence against demonstrators is wrong. With the weakening of the normativity of trying to make human dignity more effectual, then, it becomes increasingly difficult to have faith in progress towards modernity's ideals, or hope for a better future.

It is commonplace to discuss the helpful role of the media regarding the civil rights movement. I would like, however, to distinguish an issue that might be, incorrectly, conflated with "the role of the media," the significance of a general social norm against torturous or brutal state acts. I will do so, in large part, by returning to Aldon Morris' classic case study of the civil rights movement.

Morris' The Origins of the Civil Rights Movement is a well known in the literature on social movements as an example of resource mobilization theory. Resource mobilization theory is an approach to social movements that emphasizes the significance of organizational measures to overcome free rider incentives and to turn discontent into a political mobilization that can be sustained in order to achieve political or economic improvements that ameliorate the conditions that were the source of widespread discontent. ${ }^{57}$ Therefore, Morris' study is dedicated to bringing forward evidence that contradicts two familiar approaches to the civil rights movement. One is a liberal narrative that describes the Montgomery bus boycott, for instance, as spontaneously emerging when Rosa Parks was too tired to move to the back of the bus one day. The other is the approach of Francis Fox Piven and Richard Cloward, Poor People's Movements, that argues movements win most of their gains before they are formally organized, and that formal organizational efforts tend to pacify and depoliticize the movement. ${ }^{58}$ By contrast, Morris is unrelenting in 
his emphasis on the significance of the organizational efforts to mobilize large numbers of people, to engage in strategic planning, formulate goals, and sustain the movement until goals were met. Because of his emphasis on organization, the fact that evidence can be found in his text for the importance of ideological structures and symbols lends them even more significance since Morris' methodological argument should lead him to downplay these elements.

Morris criticizes studies of the civil rights movement contending that the reason civil rights leaders chose to target Birmingham, Alabama was the presence there of Eugene "Bull" Connor, who could be counted on to overreact with police brutality against civil rights demonstrators, thereby generating favorable media coverage for the movement. According to Morris, Birmingham was chosen because of the organizational strengths of the SCLC affiliate there. ${ }^{59}$ Morris also argues that if the goal was to "provoke white racists to beat blacks, then no economic boycott was needed." 00

Yet on the very next page after Morris criticizes scholarship emphasizing symbolic reasons for choosing Birmingham as a demonstration site, he notes that Birmingham "symbolically stood as the racist capital of America," and that "SCLC leaders reasoned that if racism could be defeated in Birmingham it could be defeated throughout the South." ${ }^{1}$ When Bull Connor ordered fire hoses be turned onto the protesters, and unleashed billy clubs and dogs on them as well, the photos that "captured the cruelty were distributed around the world." Morris describes how these photos made the crisis in Birmingham into the "top priority of the nation and the government." When violence broke out again in the following days, President Kennedy sent the head of the Justice Department's Civil Rights Division, Burke Marshall, to "press economic elites to reach a settlement" with the movement. Kennedy, according to Morris, also "made contact with Northern capitalists who owned most of Birmingham's businesses to use their influence over the local business leaders of Birmingham." In other words, as photos of police brutality were published nationally and globally, the Kennedy administration intervened on behalf of the movement's economic boycott. Morris also quotes Martin Luther King, Jr., who summarized the gains made by the economic boycott: "the white business structure was weakening, under 
adverse publicity, the pressure of our boycott, and a parallel falling-off of white buying." ${ }^{2}$ The organizational efforts of an economic boycott were supported by public outrage at the brutality practiced by Connor's police against the civil rights demonstrators.

Morris encapsulates the event of the civil rights demonstrations in Birmingham:

The nation was being treated to the spectacle of an American city practicing totalitarian behavior against some of its own citizens. The world, including countries that had long maintained that the United States' rhetoric about democracy was in fact a lie, watched "American justice" being displayed in Birmingham by television and satellite. At home many citizens were shocked by the oppression existing in Birmingham and looked to a President whose image epitomized liberalism and fair play. Kennedy had little choice but to act. ${ }^{63}$

Morris' analysis anticipates later scholarship discussing the role of the Cold War and the battle between the United States and the Soviet Union over which path to modernity other countries of the world should take (capitalist or socialist), and which path better realized democratic norms. ${ }^{64}$ During the Cold War, the Soviet Union could point to racial segregation as proof that the practices of the United States did not match the norms of democracy they preached-racial segregation contradicted norms of democracy, and the United States government felt the sting of these criticisms deeply. For instance, when the Supreme Court decided racial segregation was unconstitutional, it was widely publicized through Voice of America around the world. ${ }^{65}$ Domestically, Morris finds that Kennedy was forced to act by the visible contradiction between democratic norms and the police practices in Birmingham. When the nation was confronted with such clear evidence of police violence, the denial of civil rights, and the violation of democratic norms this demonstrated, the ideological contradiction was such that Kennedy could not do otherwise than to address it.

To be clear, I am not underplaying the important role of organization to the civil rights movement. I am, however, indicating the importance of a hegemonic norm and the significance of internalizing the gaze of a 
generalized other-how does one appear to others-for the success of these demonstrations. As King argues with respect to the Selma march on behalf of voting rights, the "goal of demonstrations in Selma, as elsewhere, is to dramatize the existence of injustice and to bring about the presence of justice by methods of nonviolence. Long years of experience indicate to us that Negroes can achieve this goal when four things occur." King then lists the following four factors:

1. Nonviolent demonstrators go into the streets to exercise their constitutional rights.

2. Racists resist by unleashing violence against them.

3. Americans of conscience in the name of decency demand federal intervention and legislation.

4. The administration, under mass pressure, initiates measures of immediate intervention and remedial legislation. ${ }^{66}$

Here again, one can see the compelling force of the norm against police and mob violence, and the force of seeing democratic norms being contradicted for "Americans," and the way the administration feels this democratic pressure and is forced, normatively, to act. The movement could count on public judgment and organize around that social norm.

Being involved in the civil rights movement had very high costs for participants. The risk that if one were seen trying to register to vote, one might lose one's job, the risk of being beaten, the risk of being beaten to death. What could sustain this movement? According to King, referring to students involved in freedom rides and lunch counter sit-ins, they "had faith in the future.... [T] he movement was based on hope." What was this hope? According to King, "this movement had something within it that says somehow even though the arc of the moral universe is long, it bends towards justice." ${ }^{67}$ This is the horizon of modernity, faith in progress towards justice, and the hope that human dignity could be more adequately realized. When Garland describes the early 1970s "collapse of faith" in correctionalism as the organizing presupposition of crime and punishment policies as akin to a "stockmarket crash," he is describing one aspect of the horizon of modernity's collapse. 


\section{Policing Protest in the Post-Fordist City}

The post-Fordist political economy of urban redevelopment has made the policing of disruption imperative. Over the last twenty years of the twentieth century, cities reoriented services and infrastructure away from residents and towards those who might visit the city as a tourist or shopper. Cities entered a global inter-urban competition for tourist dollars and conventions. They responded to their urban fiscal crisis by trying to remake themselves as places of fun (rather than danger or disorder), brand themselves to carve out particular niches in the global market for visitors, and to market themselves to potential tourists, conventions, and as suitable locations for global capital, by hosting "mega-events." As producers of entertainment and manufacturers of simulacra-where entertainment, marketing, and the FIRE industries (finance, insurance, real estate) meet-when a city hosts a mega-event, the event must occur without disruption for the city's branding and marketing strategy to work. ${ }^{68}$

The fate of the mega-event and the fate of the city are intertwined. New York City, known for its "zero-tolerance" crime policies, had reasons rooted in post-Fordist political economy to assist the Republican National Committee's (RNC) goal of successfully staging the Republican National Convention in 2004. ${ }^{69}$ While the RNC sought to use New York City's landscape as theatre props to reproduce a political mentality rooted in September 11, 2001, New York City, to show that it had recovered and was "back" after those attacks, needed to be able to prove it could host a successful mega-event. Though the RNC has political interests in keeping demonstrators opposed to Bush administration policies far away from the convention site, the City also had an interest in doing so rooted in the neoliberal logic of marketing and placebranding urban space. ${ }^{70}$

The Supreme Court reacted to the civil rights demonstrations of the 1960s with a number of important legal decisions that enlarged upon the "concept of a public forum" under the First Amendment. ${ }^{71}$ According to the Supreme Court's public forum doctrine, places like public parks, streets, and sidewalks are where one's First Amendment rights of freedom of speech and assembly are on the strongest grounds. At midcentury, the Supreme Court recognized that the possibility of disruption or caustic attacks were likely when First Amendment rights were exercised in a democracy. ${ }^{72}$ 
The neoliberal, post-Fordist logic of urban governance has been reflected in significant developments in First Amendment law. In a growing number of more recent lower level court decisions, courts have allowed cities hosting mega-events such as World Bank/ International Monetary Fund (WB/IMF) meetings, meetings of the G-20, or major party conventions, to zone protests away from convention sites in order to prevent disruption to the event, or to prevent conventioneers from even seeing protesters. For example, when New York City hosted the RNC in 2004, organizations seeking to host a major rally were prevented from doing so on the Great Lawn of Central Park. They were told that they could either have a smaller rally at another location in Central Park, or the city offered the organizations two alternative sites which were not on the island of Manhattan, for a rally of the size that the organizations were seeking to host. The City of Boston, where the Democratic National Convention occurred in 2004, created a "Demonstration Zone" (DZ) with opaque fabric (and wire mesh) so that protesters and dignitaries could not see each other. Located underneath elevated railroad tracks, even the judge who sustained the legality of the regulation conceded that the "pen" reminded him of a prison. Today, courts deem it sufficient if demonstrators can express themselves or voice their opinion while zoned to remote locations. These appearances are sufficient for the neoliberal reconfiguration of the First Amendment occurring in lower courts. ${ }^{73}$

These emergent legal changes are homologous to the post-Fordist experience of society's self-reflexive understanding of infinite communicative possibility. Expression is the means and the end. It is pure means. You can choose to watch the video of protesters on YouTube. Or not. You choose. Whatever. This is why it "suffices" for a right of expression to locate the demonstration far from its object of dissent. The rights of speech and assembly have been disarticulated from the politics of democracy-where there might be disruption-in the neoliberal juridical order. These legal developments correspond to an experience of communicative multiplicity without normative contradiction. This is communicative participation in the absence of democratic practices or sensibilities. Without the norms of disciplinary society, with the weakened hold of the normativity of human dignity or egalitarianism, antagonism and critique 
are increasingly foreclosed, and the mere expression and the experience of infinite communicative possibilities remain.

Unfortunately, these "cultural" developments also have consequences for expressions of police violence as well. Looking back over the last decade or so at the way protests have been policed, we can see that a post-democratic, neoliberal form of protest policing has emerged and is becoming institutionalized through repetition. Urban sociologist Alex Vitale reminds us that New York City was developing post-democratic forms of policing in the late 1990s when a riot squad rushed the stage at the Million Youth March the instant time expired on the rally permit. ${ }^{74}$ At the anti-WTO protests in Seattle, 1999, the Seattle Police Department (SPD) attacked peaceful practices of civil disobedience and used tear gas and pepper spray unjustifiably-sometimes to get a crowd to disperse or even just to move people back a few feet. The ACLU of Washington state, in addition to finding that the city's declared "no protest zone" violated the First Amendment, noted the overreaction of the SPD, inappropriate use of chemical weapons against peaceful crowds, and acts of abuse by individual officers in a report prepared in the aftermath of the protests. It also issued numerous recommendations for future police practices that would be more consistent with the constitutional rights of demonstrators. ${ }^{75}$

The Citizens' Panel on WTO Operations issued a report to the Seattle City Council Committee on WTO Accountability, which, in addition to complaining about problems with cooperation by the SPD, roundly criticized the SPD's use of chemical irritants. The "Report of the Citizen's Panel on WTO Operations" found, on the one hand, a failure on the part of the SPD to deploy adequate numbers of officers before demonstrators arrived at WTO sites, which necessitated use of less-lethal force weaponry. On the other hand, when the numbers of the SPD were bolstered by the deployment of several hundred mutual aid officers from surrounding areas, "chemical irritants remained in use." ${ }^{76}$ The City of Seattle has settled lawsuits and claims for the violation of speech and assembly rights stemming from its policing of WTO protests, such as mass arrests without probable cause, for sums totaling approximately $\$ 1.8$ million. ${ }^{77}$

John Timoney worked in the New York Police Department (NYPD) before becoming the Police Chief first of the Philadelphia Police 
Department and then the Miami City Police Department. While in Philadelphia, he was in charge when Philadelphia hosted the RNC in 2000. Groups faced significant difficulties applying for permits to march or demonstrate because of the agreement between former Philadelphia Mayor Ed Rendell and the Republican party that gave the Republicans a right of first refusal to most of the city's major gathering places. ${ }^{78}$ Police treatment of demonstrators was criticized for violating their civil rights because of tactics such as baseless charges, preemptive arrests, exorbitant bails, and abusive treatment of those detained. ${ }^{79}$ Many demonstrators sued the city (which had taken out an insurance policy for the 2000 RNC that included liability protection for claims of false arrest, wrongful detention, malicious prosecution, and assault and battery), and the city settled the suits in some cases for tens of thousands of dollars, and in others for undisclosed sums. ${ }^{80}$

When Timoney moved on to Miami, the city hosted the Free Trade Area of the Americas (FTAA) talks. Police, dressed in riot gear and often without identification, used percussion grenades, rubber bullets, and tear gas against protesters. Among those who follow the policing of protest, Miami's response to the FTAA protesters became known as the "Miami Model." Ultimately, the City of Miami settled lawsuits for violating the civil rights of demonstrators and a filmmaker for $\$ 340,000$ and the County paid about $\$ 300,000$ to settle lawsuits arising from police violence. $^{81}$

On February 15, 2003, in cities around the world, millions of people demonstrated opposition to a United States-led invasion of Iraq. In New York City, headquarters to the United Nations, Mayor Bloomberg and NYPD Commissioner Raymond Kelly refused to allow a protest march being organized by the anti-war organization United for Peace and Justice (UFPJ). The NYPD cut off access to the permitted stationary rally. They used pepper spray to back demonstrators away from barricades or against those who failed to retreat quickly enough. Mounted police drove their horses into the massive crowds, knocking people to the ground, while officers on foot used their batons. Videotape of the mounted police captures officers telling the demonstrators to "go home." Police used interlocking barricades to "pen" protesters. Those who sought to leave a pen were generally required to leave the area, and officers did not allow 
those who left a pen to reenter. This became especially problematic due to the fact that the temperature that day in New York City was approximately 15 degrees Fahrenheit and the City prohibited public restroom facilities at the rally site. Those arrested complained they were not given reasons for their arrest and they were not advised of their rights. ${ }^{82}$ At an anti-war demonstration later that spring, the NYPD unlawfully arrested protesters, detained them for excessive periods of time, and denied them access to their lawyers. The City of New York settled the suits in 2008 for $\$ 2$ million. ${ }^{83}$

New York City hosted the RNC in 2004, and made approximately 1,800 arrests in connection with maintaining security for this event, including about 1,200 on the second day of the convention. Most of those arrested were charged with minor offenses that are not generally considered "crimes," but "violations." Usually, those charged with violations are given an "appearance ticket" or a "summons," which means that they tend to be released within a few hours. When someone is "arraigned" under New York law, they are usually presented to a judge within 24 hours. During the RNC, New York City sought to hold virtually all of those arrested for arraignment, and they did not arraign those arrested in a timely manner. Hundreds of those arrested were held longer than 24 hours and some were even held prior to arraignment for up to three days. Those arrested at the RNC were held in custody at an old bus depot known as "Pier 57" which had holding cells topped with razor wire. The floors were covered with grime and oil, and therefore likely hazardous. There was no access to running water, blankets, and many in custody were forced to relieve themselves out in the open. ${ }^{84}$

After the anti-war protests of February, 2003 and the documented New York Police Department (NYPD) abuses of the rights of those demonstrators, the NYCLU obtained a court order prohibiting the NYPD from closing streets and sidewalks without informing the public of alternative routes, and requiring the police to allow people to move freely in and out of any pens set up by police. Although there were some reports of police using metal barricades, the NYPD used plastic mesh netting to rush into crowds and conduct mass arrests during the RNC of 2004. Additionally, there were numerous reports of plainclothes officers on motor scooters driving into groups of protesters. Many arrestees were 
bystanders unconnected with political demonstrations, and many of those targeted by police were observers (such as legal observers). ${ }^{85}$ The NYPD also conducted mass arrests without individual probable cause in violation of the Fourth Amendment. ${ }^{86}$ The City of New York has paid more than $\$ 1.5$ million to settle over 140 lawsuits arising from NYPD misconduct against demonstrators, while another class action has been certified against the City and is still outstanding. ${ }^{87}$

Again, there were preemptive arrests, baseless searches, baseless charges, and excessive detentions when St. Paul hosted the 2008 RNC. Journalists Amy Goodman and Sharif Abdel Kouddous, and producer Nicole Salazaar, were among those targeted by law enforcement when they were assaulted and arrested by law enforcement at the Convention. The journalists sued various agencies and the municipalities that cooperated for this event, reaching a settlement that includes $\$ 100,000$ in compensation from the Minneapolis and St. Paul police departments as well as the Secret Service. There have been numerous other settlements for civil liberties violations by various agencies that policed the 2008 RNC. These include a settlement for $\$ 27,000$ against the Ramsey County Sheriff's Department for confiscating the constitutionally protected literature of six individuals, a $\$ 50,000$ settlement against the FBI and the City of Saint Paul for a preemptive raid they conducted on the home of vegan activists, and a \$5,000 settlement for the wrongful arrest and detention of a man handing out leaflets in June to promote a rally that would take place during the RNC later that summer at the Xcel Center (the convention center that hosted the RNC in St. Paul). ${ }^{88}$ St. Paul, however, negotiated a deal with the RNC host committee requiring the host committee to purchase insurance covering damages and legal costs for police accused of "brutality, violating civil rights, and other misconduct." ${ }^{89}$ Considering that the host committee is funded by private donations, and the virtually unlimited flow of money on the part of corporations and wealthy individuals seeking to influence elections, any financial check through civil litigation against police abuse of force seems lost with this development.

Three investigations have also been launched to investigate the City of Pittsburgh for its handling of demonstrations when the city hosted the 2009 G-20 meetings. ${ }^{90}$ The investigation of the Citizens Police Review Board was impeded, however, because of the refusal of police to release 
documents normally public, such as arrest reports. ${ }^{91}$ The ACLU of Pennsylvania filed a federal suit on behalf of those swept up in a mass arrest contending that they were falsely arrested and that the police used pepper spray and fired pepper balls unnecessarily and without provocation. At least three other cases have also been filed against the City of Pittsburgh and the United States Secret Service. ${ }^{92}$ In these four cases, the city of Pittsburgh was ordered to pay attorney fees to groups seeking to hold demonstrations in the city; it settled a second case by agreeing to pay $\$ 72,000$ to a bystander whose hearing was permanently damaged by Pittsburgh's deployment of an LRAD; the city settled a case by agreeing to pay $\$ 143,000$ to two environmental groups whom the city persistently harassed, intimidated, and ultimately prevented from exercising their First Amendment rights; and the city of Pittsburgh has reached settlements with some, though not all, plaintiffs who sued the city as a result of a mass arrest at the G-20 Summit. ${ }^{93}$

The NYPD's sometimes violent harassment of Occupy Wall Street! (OWS) - to say nothing of the harassment of the Occupy! movement across the country, most notoriously the Oakland Police Department's attack on Occupy! protesters in Oakland-has resulted in several reports condemning police for violating the rights of protesters. It has also resulted in several settlements with the City of New York, and more likely to come in the future. These settlements include $\$ 50,000$ in a case in which the NYPD arrested three individuals officers believed might attend a protest; $\$ 25,000$ to a woman after she was booted to the head and hit with a baton on her shins; and the NYPD's raid on OWS and its destruction of the OWS library has led to a $\$ 350,000$ settlement. ${ }^{94}$ These sums are likely to increase dramatically once pending cases of those involved in a mass arrest on the Brooklyn Bridge, and cases involving those pepper sprayed and sucker punched, are resolved.

What are we to make of this pattern of repetitive abuse? After the shock and outrage over the way that police treated those who demonstrated in favor of civil rights in the 1960s, the policing of protest developed into a system described as "negotiated management." 95 With negotiated management, police keep open lines of communication with demonstrators, and public order is balanced by a recognition that protesters have constitutional rights of assembly and speech in places known as "public fora." 
The use of force by police should only be considered as a last resort and should be proportionate to the threat. This is a model of policing based in tolerance, and social solidarity. Therefore, it can be understood as the institutional response to the outcry against acts of visible police brutality against demonstrators exercising their First Amendment rights.

Beginning in the late 1990s, however, a pattern of police violence against non-violent demonstrators, particularly when the city is hosting a "mega-event," has emerged. The system of negotiated management has been superseded. Police aggressively use violent tactics against demonstrators, committees or boards conduct reviews and publish findings. Legal organizations like the ACLU or the Lawyer's Guild issue reports. Cities are sued. And in a number of cases, the results of civil litigation involve significant financial awards to plaintiffs. Yet there is no "learning curve." Instead, the acts of police violence are repeated.

Why has the system of negotiated management been superseded? Some suggest that cities have become hypersensitive to any signs of disorder, and policing today reflects a "zero-tolerance" mentality generally toward any sign of disorder. ${ }^{96}$ This does not, however, explain certain "irrational," excessive, or indeed expressive aspects to the contemporary policing of protest. Widely circulated examples of abuse, such as plain clothed NYPD officers driving scooters into groups of people to create chaos, "pop-up" plastic mesh pens trapping any who happen to be inside the mesh-protester or passerby, pro-active use of less lethal weaponry against non-violent demonstrators, and police departments not seeming to care about the potential financial liabilities of these violent forms of policing (or having purchased insurance to protect against potential financial liabilities), indicate something more than an aversion to disorder is at work. ${ }^{97}$

The normative value of human dignity and egalitarianism made possible the institutionalization of negotiated management within law enforcement. Today, police are expressing an affective antipathy to demonstrations of support for human dignity and egalitarianism. In the late nineteenth and early twentieth centuries in the American South, public torture lynching was a spectacle that expressed rebellion against the principles of equality, due process, and correctionalism - the principles of "modern" penology (the subject of Discipline and Punish) and social 
democracy. ${ }^{98}$ More contemporary spectacles of police in riot gear seeking to defeat political demonstrators exercising their right of assembly on behalf of a critique of the present expresses the weakening of the institutionalization of the norms of human dignity and equality within police departments. It expresses angry resistance to how the people's critique of present circumstances is the force of progress that deepens the actualization of those norms today and with an orientation to futurity. This spectacle of abusive policing may indicate an inability of the state to produce legitimacy for its policies resulting from a political embrace of neoliberalism. Without state concern for democratic legitimacy, this spectacle also manifests the collapse of faith in democratic progress immanent to neoliberalism.

When cities host mega-events, patterns of police violence against nonviolent demonstrators are repeated. We can diagnose how this repetition fails to incite collective outrage that could lead to reform. Let's return to Martin Luther King, Jr's points three and four above. In the third point, King finds that Americans of conscience will see that police violence violates democratic norms and that they will demand policies to redress this gap between norms and police practices. In the fourth point, policymakers will feel the force of the norm, feel the force of public pressure to redress the conditions that contradict the norm, and feel compelled to sustain the norm by correcting the police practices that deviate from the norm. Conditions three and four, I suggest, are lacking today with the evisceration of disciplinary power institutionalizing Enlightenment and social democratic norms. With the communicative equivalence of all opinion, and reflexivity regarding the multiplicity of communicative possibility, the normative gaze of the generalized other becomes weakened, as does modernity's meta-narrative of progress towards justice, human dignity, and democracy.

Under contemporary conditions where norms pertinent to human dignity or democracy no longer seem to function as efficiently as they once did, a video of police violence now simply adds one more frame to be communicated. It may even become communicable through someone's mashup. Contributing to communicative multiplicity, police release their own videos of clashes between police and protesters. ${ }^{99}$ They even 
release their own mashups of their videos, selectively editing them to communicate a more favorable brand. ${ }^{100}$

The upshot of this communicative multiplicity along a common denominator of communicability is, on the one hand, to cultivate a "whatever" responsiveness to videos communicating police violence. In this regard, we can appreciate some of the amusing commentary that some contribute to such circulating imagery, like the response to the viral photo of Occupy Portland's Liz Nichols being pepper sprayed by Portland police directly into her open mouth written by "sixfingered": "I bet buffalo wings don't even phase [sic] her now!" As subjects have become reflexive about mashups, however, it is unsurprising that one suspiciously wonders whether the photo itself may have been doctored (the homepage manager of The Oregonian posted a response from the photographer stating that the photo was uncropped, untoned, and certainly not photoshopped, so it appeared exactly as it had coming out of the camera). ${ }^{101}$

On the other hand, without normative standards to judge the proliferating communication of potentially mashed up photography, the guide becomes one's affective attachments. To take this line of reasoning further, the communication of a photo or video in which police violence against demonstrators appears may not inspire outrage. Some enjoy the expression of police violence against demonstrators. As "Godhelpus" writes in the comment thread to the photo of Nichols, "Welcome to the liberal oregonian who along with the freak mayor empoyered [sic] this disgusting movement and filth.... Excellent pitcher [sic] of this liberal nut getting pepper sprayed when her mouth is wide open ... [sic] I support our police department over any of these freaks." ${ }^{102} \mathrm{Or}$ as "Don Collier" writes with regard to the viral video of NYPD Deputy Inspector Anthony Bologna pepper spraying women at OWS who were already penned within orange netting on a sidewalk and therefore posing no threat at all: "These are common criminals [he is referring to the women being pepper sprayed] .... Do I enjoy watching these people suffer? I revel in it." After others criticize him for his "sick" enjoyment of the video, he responds, "I love it. Few things make me happier than pepper spray and protesters." 103 Don Collier exemplifies post-disciplinary affective attachments as he enjoys watching Bologna take revenge on those 
exercising the rights of democracy to protest neoliberalism's expropriation of the people.

"Forbalance" sums up the contemporary moment in the comment thread accompanying the photo of the police pepper spraying Nichols in her mouth. "One thing I do like about the photo," this person writes, "is that it can be interpreted in so many different ways.... Some can look at it and imagine police brutality, others can see someone's daughter who became an idiot." A video communicating police violence becomes another moment in the communication of communicability, a moment of reflexivity regarding communicative multiplicity, or a moment of enjoyment to revisit one's affective attachments. It no longer reveals a wrong or inspires collective outrage. ${ }^{104}$

Under the neoliberal conditions of communication of communicability, a video communicating the spectacle of police violence merely appears. In a niche or zone. Like the protests. Some may affectively enjoy the abuses protesters endure at the hands of police. Some might mash it up. Others might forward the link. Or they might not. Whatever.

\section{Conclusion}

In this chapter, I have re-traced a familiar argument that disciplinary power has become weaker, and that control technologies functioning through communication systems are displacing patterns of order premised on disciplinary power. Under the conditions of communicative capitalism, the normative gaze of the generalized other no longer functions with the force it once did. Control increasingly operates independently of the habits or "soul" of the subject—it operates through digital codes communicating with other digital codes. Under contemporary conditions of communicative capitalism, an experience of infinite communicative possibilities and the communicative equivalence of all opinion indicate the loss of modernity's meta-narrative of gradual progress realizing norms of human dignity and democracy.

Under these conditions, First Amendment jurisprudence has become reshaped in a neoliberal form that allows a demonstration to be zoned to a location far from (or invisible to) what one seeks to protest. The neoliberal First Amendment is satisfied so long as demonstrators can "express" 
themselves, producing communicative multiplicity without contradiction. Homologous to this, repeated acts of police using excessive violence against demonstrators in news reports or captured on YouTube videos do not compel normative outrage or changes in police practices the way they did in the 1960s. The communication of police violence does not produce a sense of contradiction, or inspire public denunciation. It adds one more icon to communicative potential. Entering the universe that communicates communicability, it shares the common denominator of communicability with a funny yell or a remix of a tortured scream. That is, it merely appears like ... whatever.

\section{Works Cited}

Agamben, Giorgio. Homo Sacer: Sovereign Power and Bare Life. Trans. Daniel HellerRoazen. Stanford: Stanford University Press, 1998.

-. Means without End: Notes on Politics. Trans. Vincenzo Binetti and Cesare Casarino. Minneapolis: University of Minnesota Press, 1996/2000.

-. State of Emergency. Trans. Kevin Attell. Chicago: University of Chicago Press, 2005.

-. The Coming Community. Trans. Michael Hardt. Minneapolis: University of Minnesota Press, 1993.

American Civil Liberties Union of Minnesota. "ACLU Plaintiffs Receive \$27,000 for Police Raids during 2008 RNC.” June 2, 2011. [Formerly http://www.aclu-mn. org/home/news/acluplaintiffsrecieve27000.htm]

American Civil Liberties Union of Pennsylvania. "ACLU Sues City of Pittsburg Over G-20 Mass Arrests.” [Formerly http://www.aclupa.org/issues/freespeech/g20/ index.htm]

Andrejevic, Mark. iSpy: Surveillance and Power in the Interactive Era. Lawrence: University of Kansas Press, 2007.

Balibar, Etienne. The Philosophy of Marx. Trans. Chris Turner. New York: Verso, 1995.

Bauman, Zygmunt. Globalization: The Human Consequences. New York: Columbia University Press, 1998.

Berardi, Franco "Bifo". Precarious Rhapsody: Semiocapitalism and the Pathologies of the Post-Alpha Generation. London: Minor Compositions, 2009.

-. The Soul at Work: From Alienation to Autonomy. Los Angeles: Semiotext[e], 2009. 
Bergman, Andrew. "CPRB battles city over G-20 documents." The Pitt News (30 November 2010). http://www.pittnews.com/news/article_655fb52c-df1d-55ee9035-e009f0f2c0fc.html

Berns, Walter. For Capital Punishment: Crime and the Morality of the Death Penalty. New York: Basic books, 1979.

Branch, Taylor. Parting the Waters: America in the King Years, 1954-63. New York: Simon and Schuster, 1988.

"Brief for the Plaintiffs." Goodman v. City of St. Paul. United States District Court of Minnesota. May 5, 2010. http://rnc08report.org/archive/1370.shtml

Center for Constitutional Rights. "Kunstler v. City of New York." http://ccrjustice. org/ourcases/current-cases/kunstler-v-city-new-york

Chasan, Daniel Jack and Christianne Walker. “Out of Control: Seattle's Flawed Response to Protests Against the World Trade Organization.” American Civil Liberties Union of Washington. July, 2000.

Citizens' Panel on WTO Operations. "Report to the Seattle City Council WTO Accountability Committee." September 7, 2000. http://www.seattle.gov/archive/ wtocommittee/panel3final.pdf

“City of Pittsburgh Settles G-20 Lawsuits." November 14, 2012. [Formerly http:// www.aclupa.org/legal/legaldocket/pipervcityofpitsburghetal.htm]

Coscarelli, Joe. “Occupy Wall Street Still Kicking in Court.” New York Magazine Daily Intelligencer (16 May 2013). http://nymag.com/daily/intelligencer/2013/05/ occupy-wall-street-still-kicking-in-court.html

- "Preemptive Occupy Wall Street Arrests Cost City \$50,000." New York Magazine Daily Intelligencer (9 November 2012). http://nymag.com/daily/ intelligencer/2012/11/preemptive-occupy-wall-street-arrests-cost-city-50000. html

Dean, Jodi. Democracy and other Neoliberal Fantasies. Durham: Duke University Press, 2009.

- "The Networked Empire: Communicative Capitalism and the Hope for Politics." Empire's New Clothes: Reading Hardt and Negri. Paul A. Passavant and Jodi Dean, eds. New York: Routledge, 2004.

—. Žižek's Politics. New York: Routledge, 2006.

Deleuze, Gilles. Negotiations. Trans. Martin Joughin. New York: Columbia University Press, 1995. 
Dreier, Peter, John Mollenkopf, and Todd Swanstrom. Place Matters: Metropolitics for the Twenty-first Century. Second revised ed. Lawrence: University of Kansas Press, 2004.

Dudziak, Mary. Cold War Civil Rights: Race and the Image of American Democracy. Princeton: Princeton University Press, 2000.

Dwyer, Jim. "Videos Challenge Accounts of Convention Unrest.” New York Times (12 April 2005). http://www.nytimes.com/2005/04/12/nyregion/12video.html

Edwards v. South Carolina. 372 US 229. Supreme Court of the United States. 1963.

Elias, Norbert. The Civilizing Process. Trans. Edmund Jephcott. Cambridge: Blackwell, [1939] 1994.

Ericson, Richard and Kevin Haggerty. Policing the Risk Society. Toronto and Buffalo: University of Toronto Press, 1997.

Foley, Ryan. "Taxpayers Off The Hook For GOP Convention Lawsuits.” Associated Press. September 4, 2008. https://www.commondreams.org/ headline $/ 2008 / 09 / 04$

Foucault, Michel. Discipline and Punish. Trans. Alan Sheridan. New York: Vintage, 1977.

-. Security, Territory, Population: Lectures at the Collège de France, 1977-1978. Trans. Graham Burchell. Michel Senellart, ed. New York: Palgrave MacMillan, 2007.

Furst, Randy. “St. Paul settles suit with RNC Protester." Star Tribune (6 February 2009). http://www.startribune.com/local/stpaul/39226432.html

Garland, David. The Culture of Control: Crime and Social Order in Contemporary Society. Chicago: University of Chicago Press, 2012.

- "Penal Excess and Surplus Meaning: Public Torture Lynchings in the TwentiethCentury America." Law and Society Review 39:4 (2005): 793-834.

Goldwyn, Ron. "RNC Protesters Set to Sue City: Dozens are Charging their Civil Rights were Violated.” Philadelphia Daily News (26 July 2001).

Hardt, Michael. “The Withering of Civil Society.” Deleuze \& Guattari: New Mappings in Politics, Philosophy, and Culture. Eleanor Kaufman, et al., eds. Minneapolis: University of Minnesota Press, 1998.

Hardt, Michael and Antonio Negri. Empire. Cambridge, MA: Harvard University Press, 2009.

-. Labor of Dionysus: A Critique of the State Form (Minneapolis: University of Minnesota Press, 1994. 
Janiszewski, Jonathan. "Silence Enforced through Speech: Philadelphia and the 2000 Republican National Convention.” Temple Political \& Civil Rights Law Review 12 (Fall 2002).

Kalven, Harry, Jr. The Negro and the First Amendment. Chicago: University of Chicago Press, 1965.

King, Martin Luther, Jr. "Behind the Selma March.” A Testament of Hope: The Essential Writings of Martin Luther King, Jr. James Melvin Washington, ed. New York: Harper and Row, 1986.

- ."Love, Law, and Civil Disobedience." A Testament of Hope: The Essential Writings of Martin Luther King, Jr. James Melvin Washington, ed. New York: Harper and Row, 1986.

Korten, Tristram. "The Timoney School of Crowd Control: Miami’s Police Chief Made Headlines in Philadelphia — and they weren't flattering." Miami New Times (14 August 2003).

Lush, Tamara. “FTAA Settlement Reached." Miami New Times (4 October 2007).

MacNamara et. al. v. City of New York. United States District Court Southern District of New York. May 19, 2011. http://www.blhny.com/docs/RNC_Order Granting Class Cert. 5.19.11.pdf

Marazzi, Christian. The Violence of Financial Capitalism. Los Angeles: Semiotext[e], 2010.

Martin, Adam. "NYPD Raid on Occupy Wall Street Just Cost the City $\$ 350,000$." New York Magazine Daily Intelligencer (9 April 2013). http://nymag.com/daily/ intelligencer/2013/04/nypd-occupy-raid-just-cost-the-city-350000.html

Martin, Greg. "Showcasing security: the politics of policing space at the 2007 Sydney APEC meeting.” Policing \& Society 21: 1 (March 2011).

Marx, Karl, and Friedrich Engels. The Communist Manifesto. New York: Penguin Books, 2011.

McCarthy, John and Mayer Zald. "Resource Mobilization and Social Movements: A Partial Theory.” American Journal of Sociology 82, 6 (1977).

McKenzie, Evan. Privatopia. New Haven: Yale University Press, 1994.

Mead, George Herbert. Mind, Self, \& Society. Charles Morris, ed. Chicago: University of Chicago Press, 1962.

Meillassoux, Quentin. After Finitude: An Essay on the Necessity of Contingency. Trans. Ray Brassier. New York: Continuum, 2008. 
Morris, Aldon. The Origins of the Civil Rights Movement. New York: The Free Press, 1984.

Moynihan, Colin. “Ejected at '04 Convention, a protester Gets $\$ 55,000$." New York Times (16 November 2008). http://www.nytimes.com/2008/11/16/ nyregion/16settle.html

New York Civil Liberties Union. Arresting Protest. New York: New York Civil Liberties Union, April 2003.

-. Rights and Wrongs at the RNC. New York: New York Civil Liberties Union, 2005.

New York Times v. Sullivan. 376 US 254. Supreme Court of the United States. 1964.

“NY Law Enforcement Caught Doctoring Video of RNC Arrests." Democracy Now! April 14, 2005. http://www.democracynow.org/2005/4/14/ ny_law_enforcement_caught_doctoring_video

"Occupy Portland: How photojournalist Randy L. Rasmussen captured that image." The Oregonian (18 November 2011). http://www.oregonlive.com/multimedia/ index.ssf/2011/11/occupy_portland_how_photojourn.html

Parenti, Christian. Lockdown America: Police and Prisons in the Age of Crisis. New York: Verso, 1999.

Pariser, Eli. The Filter Bubble: What the Internet is Hiding from You. New York: Penguin, 2011.

Parramore, Lynn. "Eli Pariser on the Future of the Internet." Salon (8 October 2010). http://www.salon.com/2010/10/08/lynn_parramore_eli_pariser/

Passavant, Paul A. No Escape: Freedom of Speech and the Paradox of Rights. New York: New York University Press, 2002.

—. "Policing Protest in the Post-Fordist City." Amsterdam Law Forum 2 (December 2009).

—. "The Contradictory State of Giorgio Agamben." Political Theory 35:2 (April 2007).

—. "Yoo's Law, Sovereignty, and Whatever." Constellations 17 (2010).

Piven, Francis Fox and Richard Cloward. Poor People's Movements: Why They Succeed, How They Fail. New York: Vintage, 1978.

Regan, Sheila. “Activists get \$50,000 over RNC Raid.” Twin Cities Daily Planet (26 May 2011). http://www.tcdailyplanet.net/news/2011/05/26/ activists-get-50000-settlement-over-rnc-raid 
Rose, Nikolas. "The Death of the Social? Re-figuring the Territory of Government." Economy \& Society 25 (August 1996).

Schwartz, Deb. "Philadelphia Law." The Nation (3 September 2001). http://www. thenation.com/article/philadelphia-law

“Seattle to pay \$1 million to settle WTO lawsuit." KOMO News (2 April 2007). http://www.komonews.com/news/local/6830252.html

Secret, Mosi. "Police, Too, Release Videos of Arrests on Bridge." New York Times (2 October 2011). http://www.nytimes.com/2011/10/03/nyregion/police-toorelease-videos-of-arrests-on-bridge.html

Shaffer, Gwen. "Bully Puppet: The City’s puppetmakers hoped their civil suits would yield big settlements and reform. Thanks to a massive attack by the city's highpowered lawyers, they're getting neither." The Philadelphia City Paper (15 August 2002). http://archives.citypaper.net/articles/2002-08-15/cover.shtml

Terminiello v. Chicago. 337 US 1. Supreme Court of the United States. 1949.

“Three reviews expected of Pittsburgh G-20 Policing." Pittsburgh Tribune-Review (8 2009). http://rnc08report.org/archive/1207.shtml

USLAWdotcom. "NYPD Police Pepper Spray Occupy Wall Street Protesters (Anthony Balogna).” YouTube. http://www.youtube.com/ watch?v=TZ05rWxlpig

Virno, Paolo. Multitude: Between Innovation and Negation. Trans. Isabella Bertoletti, James Cascaito, and Andrea Casson. Los Angeles: Semiotext[e], 2008.

Vitale, Alex. City of Disorder: How the Quality of Life Campaign Transformed New York Politics. New York: New York University Press, 2008.

- "From Negotiated Management to Command and Control: How the New York Police Department Polices Protests.” Policing \& Society 15 (2005).

Wacquant, Loic. Punishing the Poor: The Neoliberal Government of Social Insecurity. Durham: Duke University Press, 2009.

Weiser, Benjamin. "Judge Rules that Mass Arrests at a 2004 Protest were Illegal." New York Times (1 October 2012). http://www.nytimes.com/2012/10/02/nyregion/ protesters-arrests-during-2004-gop-convention-are-ruled-illegal.html?_r=0

Young, Bob and Jim Brunner. "City to Pay Protesters \$250,000 to Settle WTO Suit." The Seattle Times (17 January 2004).

Žižek, Slavoj. Enjoy Your Symptom! New York: Routledge, 2008.

—. "The Big Other doesn't exist.” European Journal of Psychoanalysis 5 (1997). 
—. Violence. New York: Picador, 2008.

\section{Notes}

1. Slavoj Žižek, “The Big Other doesn't exist,” European Journal of Psychoanalysis 5 (1997), (symbolic efficiency); Slavoj Žižek, Enjoy Your Symptom! (New York: Routledge, 2008), p. 39 (symbolic efficiency); Slavoj Žižek, Violence (New York: Picador, 2008), p. 109 (diminished symbolic efficiency of the Holocaust); Jodi Dean, Democracy and other Neoliberal Fantasies (Durham: Duke University Press, 2009), p. 63ff., gives an overview of the "decline of symbolic efficiency."

2. Norbert Elias, The Civilizing Process, Trans. Edmund Jephcott (Cambridge: Blackwell, [1939] 1994), p. 80-81.

3. George Herbert Mead, Mind, Self, \& Society, Charles Morris, ed. (Chicago: University of Chicago Press, 1962).

4. Michel Foucault, Discipline and Punish, Trans. Alan Sheridan (New York: Vintage, 1977), p. 16 and passim.

5. Ibid.

6. Ibid., p. 233.

7. Ibid., p. 135-136.

8. Ibid., p. 184.

9. Ibid., p. 90.

10. Ibid., p. 209.

11. Ibid., p. 222.

12. Ibid.

13. Ibid., p. 227.

14. Paolo Virno, Multitude: Between Innovation and Negation, Trans. Isabella Bertoletti, James Cascaito, and Andrea Casson (Los Angeles: Semiotext[e], 2008), p. 102.

15. Étienne Balibar, The Philosophy of Marx, Trans. Chris Turner (New York: Verso, 1995), p. 119-120.

16. Étienne Balibar, The Philosophy of Marx, p. 120-121 (emphases removed).

17. Ibid., p. 122 (emphases removed).

18. Ibid., p. 84 (emphasis in original). 
19. Many examples of "Foucauldian torturousness" involve the error of attributing political difference to mental or racial inferiority, while others are instances where some seek to achieve the impossibility of making an individual and a group identical to each other through fetishistic holism, and blindness to relationality, discontinuity, and antagonism.

20. Karl Marx and Friedrich Engels, The Communist Manifesto (New York: Penguin Books, 2011), Sec. II.

21. Nikolas Rose, "The Death of the Social? Re-figuring the Territory of Government," Economy \& Society 25 (August, 1996), p. 325-356.

22. Michael Hardt and Antonio Negri, Labor of Dionysus: A Critique of the State Form (Minneapolis: University of Minnesota Press, 1994), p. 261; Hardt and Negri, Empire, p. 328.

23. Michael Hardt and Antonio Negri, Empire, p. 329; Gilles Deleuze, "Postscript on Control Societies,” in Gilles Deleuze, Negotiations Trans. Martin Joughin (New York: Columbia University Press, 1995), p. 177-182.

24. Michael Hardt and Antonio Negri, Labor of Dionysus, p. 261; Michael Hardt and Antonio Negri, Empire, p. 324; Michael Hardt, "The Withering of Civil Society," in Eleanor Kaufman, et al., eds. Deleuze \& Guattari: New Mappings in Politics, Philosophy, and Culture (Minneapolis: University of Minnesota Press, 1998).

25. Michael Hardt and Antonio Negri, Labor of Dionysus, p. 241.

26. Michael Hardt, "Whithering of Civil Society," p. 32.

27. Ibid, citation removed.

28. Giorgio Agamben, The Coming Community, Trans. Michael Hardt, (Minneapolis: University of Minnesota Press, 1993), p. 1-2.

29. Ibid., p. 83.

30. Giorgio Agamben, Means without End: Notes on Politics, Trans. Vincenzo Binetti and Cesare Casarino (Minneapolis: University of Minnesota Press, 1996/2000), p. 58-59.

31. Giorgio Agamben, Coming Community, p. 82-83, 87.

32. For remixes of the Howard Dean scream, see: http://politicalhumor.about. com/b/2004/01/21/howard-dean-scream-remixes.htm; for remixes of "Don't Tase me, Bro," see: [formerly http://www.shoutmouth.com/index.php/news/ The_Top_10_'Don't_Tase_Me,_Bro!'_Remixes]

33. Here I am tracking Paul A. Passavant, "Yoo's Law, Sovereignty, and Whatever," Constellations 17 (2010), p. 553-554. 
34. Jodi Dean, “The Networked Empire: Communicative Capitalism and the Hope for Politics," in Paul A. Passavant and Jodi Dean, eds., Empire's New Clothes: Reading Hardt and Negri (New York: Routledge, 2004).

35. Christian Marazzi, The Violence of Financial Capitalism (Los Angeles: Semiotext[e], 2010).

36. Franco "Bifo" Berardi, The Soul at Work: From Alienation to Autonomy (Los Angeles: Semiotext[e], 2009).

37. Zygmunt Bauman, Globalization: The Human Consequences (New York: Columbia University Press, 1998), p. 112.

38. Franco "Bifo" Berardi, Soul at Work, p. 76.

39. Mark Andrejevic, iSpy: Surveillance and Power in the Interactive Era (Lawrence: University of Kansas Press, 2007); Lynn Parramore, "Eli Pariser on the Future of the Internet," Salon (8 October 2010); Eli Pariser, The Filter Bubble: What the Internet is Hiding from You (New York: Penguin, 2011).

40. Evan McKenzie, Privatopia (New Haven: Yale University Press, 1994); Peter Dreier, John Mollenkopf \& Todd Swanstrom, Place Matters: Metropolitics for the Twenty-first Century, second revised ed. (Lawrence: University of Kansas Press, 2004).

41. Ibid., p. 99.

42. Ibid., p. 102.

43. Ibid., p. 100.

44. Consider also Jodi Dean's discussion of enjoyment in her examples of Alec Baldwin's character in the film Glengarry Glen Ross and George W. Bush's 2003 State of the Union address in which Bush gives Americans permission to enjoy torture and extra-judicial killings as he clearly enjoyed alluding to how his regime engaged in these practices. See Jodi Dean, Žižek's Politics (New York: Routledge, 2006), chap. 1.

45. Franco "Bifo" Berardi, Precarious Rhapsody: Semiocapitalism and the Pathologies of the Post-Alpha Generation (London: Minor Compositions, 2009).

46. Here I am reminded of Quentin Meillassoux's observation that once we give up on trying to think the absolute because of the inaccessibility of the thing in itself, the consequences are only the loss of efforts to think the absolute, but not a loss of absolutes per se. That is, absolutes remain, but there is no demand for rational justification of them, so we witness the renaissance of a new religious fanaticism that is eased by the loss of proof and critique. See Quentin Meillassoux, After Finitude: An Essay on the Necessity of Contingency, Trans. Ray Brassier, (New York: Continuum, 2008). One might also consider in this regard my argument positing a logical discontinuity between Giorgio Agamben's earlier work on the "coming community" of whatever being, and 
his theorization of the state in such works as Homo Sacer: Sovereign Power and Bare Life, Trans. Daniel Heller-Roazen (Stanford: Stanford University Press, 1998); and Giorgio Agamben, State of Emergency, Trans. Kevin Attell (Chicago: University of Chicago Press, 2005); in Paul A. Passavant, "The Contradictory State of Giorgio Agamben,” Political Theory 35:2 (April, 2007), pp. 147-174. I suggest, however, that there could be a systemic or functional relation between them since whatever being might be understood as easing the emergence of a form of sovereignty that deposes popular sovereignty: see Paul A. Passavant, “Yoo's Law, Sovereignty and Whatever,” p. 551.

47. David Garland, The Culture of Control: Crime and Social Order in Contemporary Society (Chicago: University of Chicago Press, 2012), p. 63.

48. Ibid., p. 53.

49. Ibid., p. 69.

50. Michel Foucault, Security, Territory, Population: Lectures at the Collège de France, 1977-1978, Trans. Graham Burchell, Michel Senellart, ed. (New York: Palgrave MacMillan, 2007), p. 344 (economiste's critique of state economic intervention due to the limits of knowledge); Michel Foucault, The Birth of Biopolitics: Lectures at the Collège de France, 1978-1979, Trans. Graham Burchell, Michel Senellart, ed. (New York: Palgrave MacMillan, 2008), p. 80 (neoliberalism's anti-planning calls to mind the Physiocrats), p. 172 (Hayek's neoliberalism is the opposite of a plan), p. 283 (the state must not intervene due to the limits of knowledge).

51. Richard Ericson and Kevin Haggerty, Policing the Risk Society (Toronto and Buffalo: University of Toronto Press, 1997).

52. Walter Berns, For Capital Punishment: Crime and the Morality of the Death Penalty (New York: Basic books, 1979), p. 153. Berns defends the death penalty as a way for the community to express outrage.

53. For discussions of the expressive aspects of current crime and punishment policies, see David Garland, Culture of Control, p. 110; Loic Wacquant, Punishing the Poor: The Neoliberal Government of Social Insecurity (Durham: Duke University Press, 2009).

54. David Garland, Culture of Control, p. 47-48, 185.

55. Ibid., p. 184.

56. Slavoj Žižek, Violence, p. 80-81 (discussing violence as an "admission of impotence").

57. Cf. John McCarthy and Mayer Zald, "Resource Mobilization and Social Movements: A Partial Theory,” American Journal of Sociology 82:6 (1977), p. 1212-1241. 
58. Francis Fox Piven and Richard Cloward, Poor People's Movements: Why They Succeed, How They Fail (New York: Vintage, 1978).

59. Aldon Morris, The Origins of the Civil Rights Movement (New York: The Free Press, 1984), p. 252.

60. Ibid., p. 259.

61. Ibid., p. 253.

62. Ibid., p. 269.

63. Ibid., p. 271.

64. Mary Dudziak, Cold War Civil Rights: Race and the Image of American Democracy (Princeton: Princeton University Press, 2000); Paul A. Passavant, No Escape: Freedom of Speech and the Paradox of Rights (New York: New York University Press, 2002), chap. 4.

65. Taylor Branch, Parting the Waters: America in the King Years, 1954-63 (New York: Simon and Schuster, 1988), p. 113.

66. Martin Luther King, Jr., "Behind the Selma March,” in A Testament of Hope: The Essential Writings of Martin Luther King, Jr. James Melvin Washington, ed. (New York: Harper and Row, 1986), p. 127.

67. Martin Luther King, Jr., “Love, Law, and Civil Disobedience,” in ibid., p. 52.

68. Paul A. Passavant, "Policing Protest in the Post-Fordist City," Amsterdam Law Forum 2 (December, 2009).

69. Regarding New York City's zero tolerance crime policies, see Christian Parenti, Lockdown America: Police and Prisons in the Age of Crisis (New York: Verso, 1999); Alex Vitale, City of Disorder: How the Quality of Life Campaign Transformed New York Politics (New York: New York University Press, 2008).

70. Paul A. Passavant, "Policing Protest in the Post-Fordist City," p. 107-108.

71. Harry Kalven, Jr. The Negro and the First Amendment (Chicago: University of Chicago Press, 1965).

72. Terminiello v. Chicago 337 US 1 (1949); New York Times v. Sullivan 376 US 254 (1964); Edwards v. South Carolina 372 US 229 (1963).

73. Paul A. Passavant, "Policing Protest in the Post-Fordist City,” p. 106-112.

74. Alex Vitale, "From Negotiated Management to Command and Control: How the New York Police Department Polices Protests," Policing \& Society 15 (2005).

75. Daniel Jack Chasan and Christianne Walker, "Out of Control: Seattle's Flawed Response to Protests Against the World Trade Organization,” American Civil Liberties Union of Washington (July, 2000). 
76. Citizens' Panel on WTO Operations, "Report to the Seattle City Council WTO Accountability Committee,” September 7, 2000, p. 20 http://www. seattle.gov/archive/wtocommittee/panel3final.pdf. The Report is now archived with the Seattle Municipal Archives, Legislative Department WTO Accountability Review Committee, Record Series Number 1802K1, Clerk File 304446. Thanks to Deputy City Archivist Anne Frantilla for her assistance.

77. Bob Young and Jim Brunner, "City to Pay Protesters $\$ 250,000$ to Settle WTO Suit," The Seattle Times (17 January 2004); "Seattle to pay \$1 million to settle WTO lawsuit,” KOMO News (2 April 2007). http://www.komonews.com/ news/local/6830252.html

78. Jonathan Janiszewski, “Silence Enforced through Speech: Philadelphia and the 2000 Republican National Convention," Temple Political \& Civil Rights Law Review 12 (Fall, 2002), p. 121-140.

79. Deb Schwartz, "Philadelphia Law," The Nation (3 September 2001), p. 5-6; Tristram Korten, "The Timoney School of Crowd Control: Miami's Police Chief Made Headlines in Philadelphia - and they weren't flattering," Miami New Times (14 August 2003); Ron Goldwyn, "RNC Protesters Set to Sue City: Dozens are Charging their Civil Rights were Violated," Philadelphia Daily News (26 July 2001), p. 5.

80. Gwen Shaffer, “Bully Puppet: The City's puppetmakers hoped their civil suits would yield big settlements and reform. Thanks to a massive attack by the city's high-powered lawyers, they're getting neither," The Philadelphia City Paper, (15 August 2002), p. 1. http://archives.citypaper.net/ articles/2002-08-15/cover.shtml; Tristram Korten, “The Timoney School of Crowd Control."

81. Tamara Lush, "FTAA Settlement Reached," Miami New Times (4 October 2007).

82. New York Civil Liberties Union, Arresting Protest, New York: New York Civil Liberties Union, April 2003.

83. Center for Constitutional Rights. "Kunstler v. City of New York.” http:// ccrjustice.org/ourcases/current-cases/kunstler-v-city-new-york

84. New York Civil Liberties Union, Rights and Wrongs at the RNC (New York: New York Civil Liberties Union, 2005).

85. Ibid.

86. Benjamin Weiser, "Judge Rules that Mass Arrests at a 2004 Protest were Illegal," New York Times (1 October 2012). http://www.nytimes. com/2012/10/02/nyregion/protesters-arrests-during-2004-gop-conventionare-ruled-illegal.html?_r $=0$ 
87. Colin Moynihan, “Ejected at '04 Convention, a protester Gets \$55,000,” New York Times (16 November 2008) http://www.nytimes.com/2008/11/16/ nyregion/16settle.html; MacNamara et. al. v. City of New York, United States District Court Southern District of New York, (Opinion and Order by Judge Richard Sullivan certifying case as a class action), May 19, 2011 http://www. blhny.com/docs/RNC_Order Granting Class Cert. 5.19.11.pdf

88. Brief for the Plaintiffs, Goodman v. City of St. Paul, United States District Court of Minnesota, May 5, 2010, http://rnc08report.org/archive/1370. shtml; American Civil Liberties Union of Minnesota, "ACLU Plaintiffs Receive \$27,000 for Police Raids during 2008 RNC,” June 2, 2011. [Formerly http://www.aclu-mn.org/home/news/acluplaintiffsrecieve27000.htm]; Sheila Regan, “Activists get \$50,000 over RNC Raid," Twin Cities Daily Planet (26 May 2011). http://www.tcdailyplanet.net/news/2011/05/26/activistsget-50000-settlement-over-rnc-raid; Randy Furst, "St. Paul settles suit with RNC Protester," Star Tribune (6 February 2009). http://www.startribune. com/local/stpaul/39226432.html

89. Ryan Foley, “Taxpayers Off The Hook For GOP Convention Lawsuits," Associated Press, September 4, 2008. https://www.commondreams.org/ headline/2008/09/04

90. “Three reviews expected of Pittsburgh G-20 Policing," Pittsburgh TribuneReview (8 October 2009). http://rnc08report.org/archive/1207.shtml

91. Andrew Bergman, "CPRB battles city over G-20 documents," The Pitt News (30 November 2010). http://www.pittnews.com/news/article_655fb52cdf1d-55ee-9035-e009f0f2c0fc.html

92. American Civil Liberties Union of Pennsylvania, "ACLU Sues City of Pittsburg Over G-20 Mass Arrests.” [Formerly http://www.aclupa.org/issues/ freespeech/g20/index.htm]

93. “City of Pittsburgh Settles G-20 Lawsuits,” November 14, 2012. [Formerly http://www.aclupa.org/legal/legaldocket/pipervcityofpitsburghetal.htm]

94. Joe Coscarelli, "Preemptive Occupy Wall Street Arrests Cost City \$50,000," New York Magazine Daily Intelligencer (9 November 2012), http://nymag.com/ daily/intelligencer/2012/11/preemptive-occupy-wall-street-arrests-costcity-50000.html; Joe Coscarelli, "Occupy Wall Street Still Kicking in Court," New York Magazine Daily Intelligencer (16 May 2013), http://nymag.com/daily/ intelligencer/2013/05/occupy-wall-street-still-kicking-in-court.html; Adam Martin, "NYPD Raid on Occupy Wall Street Just Cost the City \$350,000," New York Magazine Daily Intelligencer (9 April 2013). http://nymag.com/daily/ intelligencer/2013/04/nypd-occupy-raid-just-cost-the-city-350000.html

95. Alex Vitale, "From Negotiated Management to Command and Control.“

96. Ibid. 
97. Therefore, police are also doing something more than simply "showcasing security" when they use "pop-up" plastic mesh or drive scooters into crowds since this creates disorder. These methods do, however, showcase aggression. See Greg Martin, "Showcasing security: the politics of policing space at the 2007 Sydney APEC meeting,” Policing \& Society 21: 1 (March, 2011), p. 27-48.

98. David Garland, "Penal Excess and Surplus Meaning: Public Torture Lynchings in the Twentieth-Century America," Law and Society Review 39:4 (2005), p. 793-834.

99. Mosi Secret, "Police, Too, Release Videos of Arrests on Bridge," New York Times (2 October 2011). http://www.nytimes.com/2011/10/03/nyregion/ police-too-release-videos-of-arrests-on-bridge.html

100. "NY Law Enforcement Caught Doctoring Video of RNC Arrests," Democracy Now!, April 14, 2005. http://www.democracynow.org/2005/4/14/ny_law_ enforcement_caught_doctoring_video; Jim Dwyer, "Videos Challenge Accounts of Convention Unrest," New York Times (12 April 2005). http:// www.nytimes.com/2005/04/12/nyregion/12video.html

101. All comment thread quotes to the photo of Liz Nichols being pepper sprayed by Portland police appear online: "Occupy Portland: How photojournalist Randy L. Rasmussen captured that image.” The Oregonian (November 18, 2011). http://www.oregonlive.com/multimedia/index.ssf/2011/11/occupy_ portland_how_photojourn.html

102.Ibid.

103. This comment thread is available online: USLAWdotcom. "NYPD Police Pepper Spray Occupy Wall Street Protesters (Anthony Balogna).” YouTube. http://www.youtube.com/watch?v=TZ05rWxlpig

104. “Occupy Portland,” The Oregonian, http://www.oregonlive.com/multimedia/ index.ssf/2011/11/occupy_portland_how_photojourn.html 
Chapter 2

\title{
The Turn to Punishment
}

\section{Racism, Domination, and the Neoliberal Era}

\author{
NoAh De Lissovoy
}

In this essay I consider the meaning and logic of the turn to punishment within the context of neoliberalism, and the hardening that this turn marks in the cultures of the criminal justice system, education, and public discourse. I begin by examining two lines of investigation that have been especially productive in their analysis of this conjuncture: The first approach understands the contemporary turn toward punishment in the context of the dynamics and imperatives of capital accumulation-and specifically in terms of a return in the present to a strategy of enclosure; the second understands the carceral turn in terms of the history of biopolitics and its regimes for organizing the order and coherence of society. I argue that these approaches are useful but incomplete, both in objective and subjective terms. In the first place, they are false to the persistent excess of repression in the present, which is characterized in each case by a structure of doubled or repeated violation. In addition, they overlook the analytical importance of accounts elaborated from the standpoint of lived experiences of injury and punishment. A consideration of these inadequacies suggests that prevailing political-economic and biopolitical accounts should be enlarged to include a contemporary phenomenology of domination and its complex dialectics of subjection and resistance. Starting from insights afforded by the historical Black radical tradition, and in particular the work of W.E.B. Du Bois, I argue that in order to adequately make sense of the turn to punishment, and neoliberalism more broadly, we need to foreground the fact and logic of racism. In the first 
instance, the legacy of racism can be understood as the secret determinant of the carceral turn in neoliberal culture. Secondly, the process of active violation that the history of racism expresses, as well as the emancipatory agency that persistently opposes it, point to key moments of a broader dialectics of domination. I argue that on the basis of this investigation we can then recontextualize neoliberalism itself as a specific conjuncture within this broader history and logic of domination, while at the same understanding more fully the carceral turn that ubiquitously characterizes it.

\section{Political Economy, Biopolitics, and the Punishing State}

Discussions of the culture of neoliberalism have focused on two central processes or manifestations. The first of these is the experience of the overall process of privatization that characterizes the neoliberal moment. Neoliberalism aggressively privatizes public and collective spaces, relationships, and institutions. At the macro level, this means a terrific colonization of the world and lifeworld by capital, and the conversion of almost all moments of social life into moments of surplus extraction. Public discourse is increasingly yoked to the ideologeme of the free market, which serves as the cover for underlying processes of class war from the top, financialization, and deregulation. ${ }^{1}$ At the micro level, as cultural theorists have shown, these basic structural shifts set in motion a fragmentation of social life and a reterritorialization of collective dilemmas and contradictions onto the impossible terrain of the individual and his or her "choices." In this way, consumerism is not merely substituted for richer modes of social identity and relationship, but is even offered as the solution to existential problems. Likewise, genuine political deliberation is made obsolete, as the very space of citizenship fragments into the private spaces of online identities and networks, homeowners associations, media preferences, and the like, leaving those who are excluded from the privileges of the market and its associations to the wilderness of the decaying and vestigial public and its neglected streets, schools, and communities. This process is essentially a recasting of social identity and experience in terms of the metastasizing logics of reification and 
accumulation. In this domain we recognize ourselves only in the flattened avatars we navigate through terrains of competition, consumption, and spectacle.

The second central expression of neoliberal culture that has been focused on by critics is the tendency toward authoritarianism, hyperdisciplinarity, and punishment in the state and civil society. Within this logic, networks of solidarity and obligations to the vulnerable are replaced by a culture of blame, externalization, and denial —as those who are unable or unwilling to market themselves or to be marketed, or who are selected as the target for the collective fears and dissatisfactions that accompany the atomization of public life, are subject to intimidation, violence, and incarceration. This process is the obverse of the businessification and privatization of society mentioned above-marking its dead zones and limits as well as the exclusions by which the successful neoliberal identity recognizes itself. The punishing state has been noted particularly in terms of the growth of the prison-industrial complex, the targeting of people of color by the criminal justice system, attacks on immigrants, and the demonization of youth. ${ }^{3}$ It is also represented globally in an empire of surveillance and discipline organized around the permanent assault on so-called "rogue" states and societies. ${ }^{4}$ It is familiar in the educational sphere in the form of heightened surveillance and security in schools, draconian disciplinary procedures, aggressive accountability systems which stigmatize and push out "low performing" students, and a general culture of accusation against students and teachers.

It is the meaning and logic of this turn to punishment-this second essential tendency within the culture of neoliberalism-that I examine here. There have been two main lines of investigation that have been most productive in analyzing this tendency. Each of these is powerful and useful, and each has important drawbacks that we need to consider if we are to more fully understand and more effectively respond to the current moment. The first approach understands the turn toward punishment primarily in terms of the dynamics and imperatives of capital accumulation - that is, in terms of the social upheavals brought on by the recomposition of class struggle and political economy that neoliberalism represents. The second approach understands the carceral turn in society in terms of a reordering of the modes and intelligibility of power itself, 
specifically in terms of the history of biopolitics and its regimes for organizing the order and coherence of society.

The first approach just mentioned understands the authoritarian texture of neoliberal society as essentially the effect of a more fundamental process of enclosure that characterizes the economic logic of the current moment. Grounded in Marx's ${ }^{5}$ own analysis of the original appropriations of communal space and resources that created the fund of wealth that allowed for the development of capitalism, this perspective recognizes, in Harvey's ${ }^{6}$ terms, a contemporary process of "accumulation by dispossession" which motivates a whole set of disciplinary interventions against poor and working people globally. Both the violent founding of capitalism as well as contemporary forms of plunder are explained as processes that underlie and make possible the normative order of capital-in both cases resources are appropriated essentially by force, and outside of the process of exchange, as a platform and entry point for the market proper and for familiar processes of capital reproduction. Within this overall process, the strong arm of the state does the disciplinary work that capital requires. As Marx describes, there are two key moments of this violence. The first is that which accompanies the original dispossession of the population: the driving of people from the commons that has traditionally been theirs. The second moment of violence is the bending of bodies and wills to the new regime of accumulation - and the use of the state to police the political boundaries of this system.

In the case of education, the hardening of systems of assessment and discipline, and their obsessive indictment of the poor performance of students, teachers, and parents crucially accompanies an aggressive push for the privatization of the public school system. As capital moves to colonize a social sphere from which it has largely been excluded, it works at the same time (through state education policy) to disparage the moral and political claims of public school constituents on the spaces of schools and on the very meaning of education. ${ }^{7}$ This is a contemporary instance of the first moment of violence associated with the process of "accumulation of dispossession" described above, in which traditional rights to the commons are outraged in the process of enclosure. The growth of the prison-industrial complex might then represent the second moment of assault, as those who have been made redundant (through the rationing 
of educational credentials, downsizing, and attacks on social services) are pronounced guilty of the crime of their own dislocation and submitted to the discipline of the system of "corrections." ${ }^{8}$ Capital by this means attempts both to destroy the possibility of resistance and, as it happens, to colonize and profit from another social domain traditionally controlled by the state (the prison system).

An alternative to this political-economic analysis of the turn to punishment in neoliberalism, and the second influential approach to this problem, is focused less on the process of accumulation and more on the form and sense of power itself. Specifically, this second approach understands the turn toward state violence, hypercontrol, surveillance, and detention in terms of biopolitics and its form of rationality. Starting from Foucault's ${ }^{9}$ insight into the centrality of the management of organic life-bodies and populations of bodies_to modern politics, critics like Agamben ${ }^{10}$ have identified the proliferating points of political decision on what and who deserves to live, on what is healthy and what is not, as the essence both of official totalitarianism and of state terror generallyas for instance in the long history in so-called "democratic" societies of experiments in detention and torture, precisely at the edge of the law. In this zone of indistinction between public health and eugenics, biopolitics appears as often as not in the form of thanatopolitics - a politics in which population management takes the form of pathologization, violence and murder. The punishing state associated with contemporary neoliberalism would then represent the latest and most perfect expression of the saturation of society by biopower, since in the present this logic appears to be at once globally projected (in the far-flung gulag of the US empire) and at the same time miniaturized into the substance of everyday life (for example in the pervasive stigmatization and medicalization of deviant identities and experiences).

From this perspective, and in contrast to the economic approach, the contemporary culture of punishment is not immediately identified with the demands of capital. At the same time, however, it is important to remember that Foucault ${ }^{11}$ identified the birth of biopolitics with the moment in which the bourgeoisie transposed the social antagonisms that were previously thought to fracture society (into irreconcilable races or classes) onto the interior of a unified political space and project. Thus, 
histories of conflict and the notion of war itself, which were variously evoked by the aristocracy, the monarchy, and the emerging bourgeoisie to ground their own rights and virtues were reinvented in the modern period as a criterion of administration - a biopolitical management of apparently organic antagonisms rather than a principle of political cleavage or outright war. So to the extent that biopolitics is identified with the triumph of bourgeois society, it is linked in the same moment to capitalism, and this nexus points to the logic of efficiency that power now projects throughout society and the economy. Furthermore, the connection between biopower and capitalism has been explored by theorists who have argued that it is precisely capital's full-fledged emergence onto the terrain of the biopolitical that marks the contemporary moment. For Hardt and Negri, ${ }^{12}$ the very reproduction of life and society has now become privileged terrain for the appropriation of surplus value. Neoliberalism might then be said to mark this merging: When capital becomes biopower it is no longer simply a political-economic category, but rather a figure that unites the political, cultural, social, and economic within one domain of force (a domain that these authors call "empire").

The biopolitical analysis of the carceral turn in neoliberal culture illuminates the logic by which exercises in injury and violation are persistently rationalized as humane, scientific, and efficient. Thus, between sessions of torture, the dietary preferences of "enemy combatants" in detention centers are apparently respected. In the US, private prisons are marketed to cities as crucial anchors of community and as means to livelihood for prospective employees. To take another example, racial profiling, within the logic of biopower, is represented as the activity of a fantastic intelligence, operating powerfully and beneficently behind the scenes to discover threats to public safety according to algorithms more sensitive-in a changed landscape-to the complex tensions between privacy and security than the old rationales. Understanding contemporary cultures of punishment in terms of biopolitics allow us to recognize the impulses to population management, purification, and production that live, horrifically, within them. 


\section{Gaps and Impasses: Excess, Experience, and Subjection}

The approaches that I have described above to understanding the turn in the neoliberal moment toward a culture of punishment are important and useful. Nevertheless, I believe that they also suffer from some significant inadequacies. They are incomplete both in objective terms (i.e. in their account of the social logic governing the carceral turn) and in subjective terms (i.e. in their sense of the importance of experiences of injury and punishment). Furthermore, they do not account for the persistent excess and doubleness of domination. I believe that these inadequacies suggest the need for an analytic that is more than narrowly economic or political in its approach to this question; or rather, that the political and economic accounts we give should be enlarged to include a phenomenology of domination in contemporary context. As I describe below, this means in the first instance a confrontation with the fact and meaning of racism, and second, an extrapolation of the lessons learned from this investigation toward a broader theory of domination. The punishing state within neoliberalism can then be contextualized within this richer framework. To begin with, however, it is important to explain the shortcomings of the analyses I have described above.

In the first place, these accounts do not fully respond to the excess that characterizes the turn toward a security state and a culture of punishment. In this brave new world, the intensification of punishment means not just increased detention, but also the invention of new and exceptional categories of detainees (e.g. "enemy combatants"); not just the mainstreaming of torture, but also the production of a technical discourse which assaults the possibility of an ethical response (e.g. "enhanced interrogation"); not just the increased surveillance of communities of color and their recruitment into the prison system, but also a brutal coarsening of the conditions of incarceration (e.g. "supermax" facilities, or trying youth offenders as adults). In education, not only are working class students consigned to underfunded and poorly resourced schools, but in addition, they are made responsible for the system's own failures by means of the ideological apparatus of standardized assessment and accountability systems. ${ }^{13}$ In all of these cases, there is not merely a hardening of conditions, but a double or repeated hardening, according to a logic in which the pathologization of vulnerable populations becomes the ground for 
further assaults. In this regard, the cultural turn toward punishment in the current moment corresponds to the qualitative shift, in the economy, from vanilla capitalism to the neoliberal economy proper (we might call it "enhanced capitalism") — an economic moment characterized not just by increased exploitation, but by outright abandonment; and not just by colonization of the public by the private, but by efforts to dismantle the public sphere altogether.

This excess of assault does not easily cohere with the theories of accumulation and biopolitics described earlier. The first-politicaleconomic - approach to understanding this turn that I described above makes sense of it in instrumental terms as the essential tool for facilitating and consolidating dispossession. This view understands state violence and the culture that supports it as instruments for terrorizing people into accepting the terms of capital and its encroachments. ${ }^{14}$ However, this account seems less than convincing in the ubiquitous cases in which the intensification of repression in fact increases resistance. Thus, with regard to what we might call the global culture of empire, detainee abuse, drone attacks, and targeted assassinations seem to be aimed as much at producing chaos and destabilization as they are at consolidating political and economic interventions. Furthermore, the economic explanation misses the structure of affective intensities and investments, or the organization of pleasures, that punishment mobilizes. The hardening in the criminal justice system, public discourse, and elsewhere exceeds itself as mere repression and invents unprecedented terrains, for the powerful, for experimentation in injury. If there is a logic at work here, it is not only an instrumental one, but also a logic of domination proper; we might say that what these processes partly reveal is precisely a for-itself of domination.

From the perspective of the second-biopolitical-account of contemporary carceral culture that I described above, state violence in the modern period is described as an extrapolation of biopower, in which its extended dominion over life is proven in widening circles of murder, eventually directed almost against society as a whole in the cases of colonialism and genocide. ${ }^{15}$ However, while they understand the operation of power and its contemporary assaults in more than instrumental terms, accounts starting from the notion of biopower also assimilate the effects 
of power to a social rationality that is removed from the materiality and experience of violence. Racism, for instance, though it is an important category in these analyses, cannot be understood adequately without building from the experience of its assaults and from the vantage point of its targets. But Foucault ${ }^{16}$ aims to do away with the apparatus of oppressors and targets - of power operating on or against persons (as opposed to constructing them). The genealogy that he traces contextualizes power's innovations within the development of historical knowledge of war; biopower represents the application of the bourgeois reinvention of this problematic as one of public health, of internal war against society's enemies. In the process, however, the lived experience of domination, its existential meaning and reality, are abstracted from-both historically and in the present neoliberal moment. Understood as a discursive management of differences, power's concrete injuries to persons are deemphasized, or at least these do not constitute the vantage point from which to determine its essential meaning.

I believe that in order to understand power in the present, and its application in punishment and repression, we need to move toward a conceptualization of a logic of domination proper-beyond the theories of accumulation and biopower that I have described. First, the excess of punishment in the present makes it more than an instrument for guaranteeing the unobstructed accumulation and reproduction of capital. Second, in constructing a phenomenology of domination, the importance of starting analytically from the standpoint of those who have suffered from its ravages means that power cannot be understood merely as a strategy at the level of knowledge, as a regime of truth for modernity. Power, as domination, sticks to subjects, enrolling them into a complex dialectics that we cannot understand without the notions of repression and oppression, of perpetrators and targets. We need to start from an analysis that takes this phenomenology of subjection and injury, and its structure of excess, fundamentally into account. In this way we can better understand the meaning of the contemporary punishing state and we can also begin to build a more general account of domination. 


\section{The Logic of Racism and the Carceral Turn}

The crucial starting point, I believe, for building an analysis that is sensitive to the central aspects of domination I have mentioned, is a consideration of racism. The history of racism shows clearly the surplus that characterizes power as domination. The analytic tradition that starts from the experiences of those who have suffered from racism also reveals in this history the materialization of power in contests between subjectsa concrete theater of subjugation-and in the same moment, the possibility of resistance and emancipation. Furthermore, I argue that the dynamics of racism illuminate the meaning of contemporary repression as a whole; this can allow us to understand what is perhaps unique in the current conjuncture and what is not, and to build outward toward a more general theory of domination and a more useful understanding of neoliberalism. Specifically, I argue that racism constitutes the secret ingredient in the carceral turn in neoliberal culture, accounting in the first instance for its structure of overdetermination; at the same time, neoliberalism represents the moment of a tendential generalization of this excessiveness across society, which points to a logic of domination proper at work in society that is distinct from (though linked to) the economic and biopolitical logics described above.

While the approaches I have discussed above do consider race and racism, their understanding of these phenomena is distorted by their focus on the imperatives and experiences of elites-on regimes of governmentality and surplus extraction. By contrast, an approach to this problem that starts from the standpoint of the targets of racism can provide a richer picture of racism's force and meaning - the range of its registers, and the form of its organization in concrete action. ${ }^{17}$ In the first instance, an attention to racism in the context of the neoliberal conjuncture has two uses: 1) it exposes the contemporary punishing state as in fact essentially racist, and this racism as its secret determination; 2 ) it points to a dialectics of violation that has been historically consistent, and which can serve as a model for understanding the principle of excess within domination more generally. Anchoring this investigation in an antiracist standpoint, and in a perspective informed by the experience of racism's ravages, means that the analysis of domination cannot be exhausted through reference to a governing rationality or regime of truth, 
but rather should always be connected to and refer back to lived histories, and to the unreason that characterizes domination as existential fact. In this analytical effort, the historical Black radical tradition, and the work of W.E.B. Du Bois ${ }^{18}$ in particular, is an indispensable resource.

In the first place, I have described above how prevailing approaches to understanding the culture of punishment in the neoliberal moment fail to account for its essential excess. However, if we recognize that this punishing culture is fundamentally linked to a familiar logic in the history of the US - the logic of racism-then its excesses do not seem so novel. Angela Davis ${ }^{19}$ makes a compelling case that the preservation of the system of capital punishment and the growth of the prison-industrial complex represent a continuation in the present of the legacy of slavery and its exceptional juridical system. She argues not only that prisons function to preserve racism as system and structure, but also that they are the repository of the absolutely authoritarian form of juridical power inherited from slavery. Slaves had essentially no rights in the face of the law and its threats of violence; it is likewise toward the limit of this absolute authority and violence that contemporary legal and carceral systems tend. In addition, while Black people and other people of color are disproportionately the targets of the system's excesses, nevertheless Whites also partly suffer from its fundamental exceptionality and irrationality. (The distinction between this analysis of exceptionality and the biopolitical one should be clear: while racism for Agamben is a central expression of the zone of indistinction between fact and law at the heart of Western sovereignty and authoritarianism, for Davis racism is the crucial source of this authoritarianism.)

If we start from this insight, then the double hardening, described earlier, that characterizes the turn to punishment in the present might be understood as stemming directly from the intensification of repression already produced by racism. In other words, the rationale for an exceptional system of detention that suspends basic rights of due process (in the cases, for example, of both undocumented immigrants and terrorism suspects) is already given by racist law. That is, the system of assaults that was engineered in the context of the history of oppression of Black people and other people of color in this country is now being applied on new terrain. ${ }^{20}$ Another way to understand racism as determining the 
contemporary carceralization of politics and culture is to recognize its persistent focus on people of color, even in the moment of globalization-so that once again Brown folks, those perceived for instance to be Muslims or immigrants - are the targets around which the innovations of the legal system are organized, and whose persecution (in a racist culture) becomes the rationale for suspensions of democratic rights and processes. The doubleness of domination, from this perspective, is not exactly the effect of a new discipline required by a new regime of accumulation, or the extension of the paradigm of the "camp" to society generally, as Agamben ${ }^{21}$ argues, but rather the familiar doubleness of racial domination and White supremacy, now writ large for the global era, and for its new terrains of racialization.

Secondly, analyzing the logic of excess expressed in the historical dynamics of racism can serve as an entry point to a general theory of domination as a distinct historical and social principle. Du Bois shows that racism has comprised not merely the limitation of opportunities, but in addition has always been an active assault. ${ }^{22}$ Thus, the guarantee and secret determination of the order of unequal rights represented by Jim Crow was the active terrorization of Black people by the Klan and by the state. Racism as a social logic has always been manifold, opportunistic, and enveloping — an attack and intimidation on all fronts, expressing a logic of terror rather than simply discrimination. In analyzing the counter-revolution of Whites in the South against Reconstruction, Du Bois describes a generalized assault that was simultaneously political, cultural, psychological, economic, physical, and juridical. Not only were Blacks denied the right to vote, they were also forced into a caste system that marked them as inferior in every interaction with Whites. And not only were they forced to identify psychologically and spiritually with this system, but they also suffered physically from the sickness that this assault encouraged, and which economic exploitation and marginalization also produced. Racism, from this perspective, has always been a logic of violation in addition to a process of subordination ${ }^{23}-\mathrm{a}$ bitter contest in which the oppressors have struggled not merely to prevail against the oppressed but even to break them, and to make them responsible for their own misery. 
The assault represented by racism has been active, unresting, and willful-not simply required of Whites but enjoyed by them, a system of injury that includes but also exceeds the effects of a political or economic strategy. Even as systemic and structural, the logic of racist violation cannot be made sense of outside of the domain of the subject, and the subjective struggle for and against domination-and for the pleasures of domination. This means attending to the persistence of a subjective dialectics in racism, which acts underneath as well as within the structural system of racism. ${ }^{24}$ For example, not only does the rage of the police against Black people shore up a structure of material privileges for Whites; conversely, a racist culture facilitates the subjective expression of and experimentation with cruelty against people of color by police and others. Racism is in this way at once motivated and desired. Contrary to the argument of Foucault, ${ }^{25}$ racism thus preserves a form of sovereignty associated with what he called a "subject-to-subject cycle" and which he describes as being rendered obsolete by modernity and its logics of disciplinarity and normalization.

By the same token, this persistent dialectics points also to the integrity of the subjugated, and to the possibility of emancipation. As Du Bois ${ }^{26}$ describes, in spite of the outrages visited upon them, Black people after the Civil War nevertheless survived and often thrived, persistently thwarting the demoralization and destruction prepared for them by the resurgent White South. And perhaps this human irreducibility, this refusal to submit, provokes after all the extremity of repression. Power in this way is doubly enraged-enraged at the audacity of the claims of those who have been constructed as inferior, and enraged again at their refusal to be broken. The agency and humanity of the oppressed, even within the depths of violence, inhabits immanently the logic of domination as its necessary obverse. The recognition of this agency, and the possibility of emancipation that it points to, is a crucial advantage of the existentially grounded work of Du Bois, and of the antiracist tradition generally, as against a biopolitical analysis for which the contradictions of sovereignty remain internal to power as a matrix of intelligibility. In the biopolitical framework, subjects dissolve into temporary effects, and in this way remain complicit and coincident with power, rather than being acted upon or against. 


\section{Power, Domination, and the Neoliberal Era}

From this perspective, the punishing state accompanying the neoliberalization of the economy is not a new formation. It is the familiar face of power as racism, which has long oppressed and repressed communities of color in the US. In its extrapolation to the complex landscape of globalization, it nevertheless builds on a constant repertoire of strategies and tactics for domination, tested over time on Black and Brown people in the US. Indeed, the current cultural turn points to the urgency of attending to histories of race and racial domination in analyzing power. However, while the novelty of the neoliberal moment conceals a familiar history of racial oppression, what is peculiar to the current conjuncture is the extension of the logic of domination to new social domains.

In education, for instance, the culture of blame has reached a fever pitch; the vituperation against teachers, schools, and communities now threatens to destroy the public system altogether. In this sphere, a stigmatization that had been reserved for students of color has been inflamed to the point that it touches on public schooling more generally, and, one is tempted to say, even on the prospect of education itself - to the extent that dominant reorganizations of teaching and curriculum aim to do away with the very possibility of real inquiry and learning. This is part of a larger pattern in neoliberalism noted by David Theo Goldberg, ${ }^{27}$ in which the government itself (as social service provider and agent of affirmative action) is read as Black, and becomes the target of racist resentment and suspicion. But one could also understand this process as a ramification of the repressive moment in racism toward a more general war against society. In this way, racism becomes the starting point for a generalized assault on public life.

I would like to suggest that if analyzing contemporary politics and culture under neoliberalism in terms of regimes of accumulation and biopower is useful but still inadequate, as I have argued, then we need to begin to sketch the outlines of what I would call a regime of domination, identified most closely with the experience of racism, but perhaps not exhausted by it. Contemporary neoimperialism, authoritarian culture, and state violence all point to a generalization of this regime, in a way that crucially articulates the logic of capital to the histories and repertoires of racism. On the one hand, crises of accumulation and their aftershocks 
have clearly precipitated a class offensive against working people (while also not seeming to fully account for the intensity of repression); on the other hand, a familiar racist culture reemerges in disguise in contemporary forms of the repressive state apparatus (while also extending beyond its familiar forms to touch the organization of public life in a new way). In this context, the notion of domination, dusted off and recalibrated, might be a name for this point of intersection and combination.

Such a conceptualization would be motivated in part by a sensitivity to the crucial moment of unreason in contemporary politics and culture. As I have described, it is a stretch to calculate the current forms and intensity of repression as a simple effect of capital's accumulative drive, or to understand them solely as an expression of contradictions within the realms of knowledge or discourse. At the same time, the very materiality of domination, its embeddedness in the historical antagonisms of racism and exploitation, argues against any metaphysical notion of power. Domination is an entirely historical force and project the subject of which, however, we have not yet fully traced and recognized. This tension can be seen clearly in Du Bois' Black Reconstruction in America, ${ }^{28}$ which generally aims to narrate the history of racism as an expression of the dynamics of capitalist development, and yet which at its most vivid moments points beyond this analysis to a dominative force that makes racism, after all, irreducible to class struggle. ${ }^{29} \mathrm{On}$ the other hand, as $\mathrm{Du}$ Bois consistently suggests, racism itself, looked at closely, points behind the superficial commonplaces of race to a different and more fundamental theater of power.

Decolonial theorists have argued that Western culture, epistemology, and politics are shaped at the source by the impulse to conquest, and that a society not governed by the imperatives of war will have to start from a foundation that comes from outside the West and its traditions. ${ }^{30}$ While this perspective may too easily separate and reify the West and the rest, I believe that only a project that takes on these first principles of being and thinking will be able to expose the logic of domination that the neoliberal moment has so terribly multiplied. Focusing on the notion of domination may usefully challenge the narrow economic and political emphasis that the term "neoliberalism" itself tends to reinforce, and instead point to the complex interpenetration of these spheres with those of culture 
and spirit as well. After all, familiar critical analyses crucially point to a process of violation that nevertheless remains unexplicated in terms of its own particular structure. For example, the notion of "accumulation by dispossession" ${ }^{31}$ explains the appropriation of collectively held land and resources by capitalists, but does not convincingly start from the human suffering and response that accompanies this process, not as its mere effect but as part of its central meaning.

In state violence, and in the public cultures of racism and xenophobia that accompany it, the psychical and spiritual investment in domination not only supports elites but determines them as well-making of power a kind of total and enraged subject of the social. This logic of domination is always beyond itself as mere hegemony, essentially reckless with regard to its own self-preservation. In this way, the point of racial profiling or efforts to restrict the access of immigrants to public services is not only to protect the privileges of elites but also and equally to injure those who are vulnerable, those who are offered as targets for the drive and need for domination. The turn to punishment in the neoliberal conjuncture would then represent a moment of liberation for power as domination, an awakening to the possibilities of its rage. In neoliberalism, power and capital reach beyond mere subordination and exploitation, and grow into themselves as principles of violation.

Proposing the notion of domination as a framework for understanding neoliberal politics and culture may seem like a theoretical retreat, to the extent that it pries this moment loose from the frameworks that have most particularly addressed it. However, the contemporary analytic of domination that I have sketched here is not undefined. Rather, it is characterized by several key aspects that I have highlighted above: 1) it connects the economic and the political, and thus articulates an analysis of capital to an analysis of power, including biopower; 2) it reveals the simultaneity of the objective and subjective, pointing to the coincidence of structural and individual effects; 3 ) it exposes power as characterized by an essential surplus expressed in the doubleness of its operation and intensity; 4) it includes within its dialectic the fact of resistant agency, as the object of power's rage and as the remainder it can never overwhelm; 5 ) it points to the present unfolding of domination across the length of 
the global, as it is given increasingly free reign within contemporary processes of carceralization, privatization, and permanent war.

Political work has to begin from a witnessing of domination, in its fullness and complexity, rather than from easy explanations that seek to exorcise it. The impulse to act which founds political praxis comes after all from this attention rather from a final knowledge of reasons and determinations. Frantz Fanon's ${ }^{32}$ writing on colonial society and anticolonial resistance, for instance, takes the form of a complexification of analysis that is also an interrogation of given critical accounts. His specific description of colonial racism is achieved by means of a critique of the failure of available critical knowledges (Marxism, psychoanalysis, and philosophy) to fully respond to its dynamics. What he leaves us with is a fuller description of power, and also an ethical demand that starts from and points to its ultimate unreason-an exposure of the murderousness of the exalted "humanism" of Europe, and an argument for a different and more authentic humanism. In the same way, as he challenges the erasure of the Black experience in dominant US historiography, Du Bois ${ }^{33}$ implicitly confronts the failure of Marxism to start from experiences of racism in conceptualizing the inner principle of historical oppression. I believe that to respond to these theoretical challenges is to foreground the problem and phenomenology of domination, as a problematic that links race to capital and points beyond both, a category that is at once material and existential. ${ }^{34}$ If this means taking a step back from the most fashionable approaches to power in contemporary theory, and a step towards the still incomplete (and still revolutionary) projects of the thinkers that I have just mentioned, so be it.

These antiracist and anticolonial traditions offer an essential starting point for making sense of power in the present, and their analyses can be extended to respond to the particular moment of neoliberalism, and in particular to the turn to punishment in culture and politics that I have highlighted in this essay. The global reach of this trend, its colonization of almost all domains of social life, and the new forms of counter-subject it produces all have to be imaginatively reckoned with. Familiar democratic and critical rhetorics that emphasize engaged citizenship, voice, and ideology critique are important, but they also need to be reconfigured to address a process of assault that is as much immanent and ontological as 
it is "political" or "cultural" in the ways we are accustomed to. The global racism of neoliberalism, for instance, acts directly on beings and bodies through forms of surveillance, interrogation and detention, as much as through the ideological work of constructing friends and enemies. Likewise, the subject of resistance has to be recognized as irreducibly present even in these occupied and injured beings and bodies as an ontological fact and horizon, rather than only in the overtly political moments of organized protest. ${ }^{35}$ The biopolitical analysis of contemporary struggles over "bare life" is an important starting point in this regard, but it has to be supplemented by a recognition of the agency that is always present and stirring within the pulsating targets of power. The biopolitical project of reducing human being to mere existence ultimately fails in fact, as human beings persistently assert their presence and survival in the face of injury. In this context, a radically humanist commitment should take the form of an urgent responsiveness to the irreducible agency and emancipatory minimum that lives within and against power's extended assaults.

\section{Conclusion}

For educators and cultural workers, these reflections suggest that it is important to help students and others to make connections between their own experiences and broader social processes without attempting to explain these experiences away, or to substitute official critical analyses for vernacular understandings. In schools, it is important to analytically connect the turn toward punitive forms of so-called accountability, hyperdiscipline, and the blurring of the line between school administration and law enforcement to larger processes of carceralization in global society. ${ }^{36}$ However, the notion of domination that I have described here brings together a range of modalities of power, including exploitation, normalization, marginalization, and violence; discovering the links between these processes and the broader logic they point to involves working organically from the standpoint of those affected. Thus, recent walkouts by high school students in the Southwest have creatively connected protest against national anti-immigrant politics and the criminalization of youth to struggles for critical and culturally relevant pedagogy. These protests have crucially called out the racism that operates at the 
heart of mainstream educational policy while connecting it to issues of colonialism, demonization of youth, and economic oppression. This creative and synthetic impulse, which precisely uncovers the complex contours of domination in the neoliberal moment, challenges the narrowness of prevailing analyses in education scholarship, which tend to understand inequities and oppression in terms of isolated principles of ideological hegemony or racialization. ${ }^{37}$

In addition, critical pedagogy and critical theory generally should learn to recognize the irreducible agency that lives within individuals and communities, including students, even in the face of oppression. ${ }^{38}$ At the level of theory, this means resisting the tendency of both structuralism and poststructuralism to absorb subjects, as mere effects, into exhaustive accounts of society. At the level of praxis, this means a refusal of fatalism and cynicism, not out of mere progressive virtue, but rather because fatalism and cynicism are false to the truth of the ubiquitous fact and potential of emancipation. Critical pedagogy and theory have often described this potential as initiated by the intervention of the teacher or leader ${ }^{39}$; it is important now to recalibrate our sense of the function of critical teaching to see that it interacts with subjects that are always active and in motion (however constrained by power at the same time), and always proposing, incipiently, their own refusals of the logic of domination. Popular and digital youth cultures, for instance, should not be derided as signs of an escapist orientation, but rather recognized as experiments in organizing alternative social and political communities, as we have seen in dramatic fashion in the uprisings of the Arab Spring. In this context, critical pedagogy should be reimagined as more profoundly collaborative with students and young people, and their autonomous interventions, rather than as leading the charge of critique and praxis.

Neoliberalism names a doctrine and tendency within the capitalist economy as well as a broader social process. However, my analysis of the turn to punishment in culture and politics in the present moment shows the limits of identifying the set of narrowly economic imperatives associated with neoliberalism as the essence of the current conjuncture. Instead, analyzing the current hardening of conditions in the areas of criminal justice, education, and public life from an antiracist perspective sensitive to the continuity between these contemporary formations and historical 
racisms exposes a larger and persistent problematic of domination as a more useful matrix for understanding power. From this perspective, the turn to punishment in the neoliberal moment, if we can understand the latter term now in a larger sense, does not so much name the invention of new repressions and assaults - which are generally familiar from the history of racial subjugation-as it does their amplification and extension. In fact, the contemporary carceralization of society and the proliferating violence of neoimperialism indicate the metastasis of this process, and point to the urgency of tracing the shape of domination as an overarching logic. This logic, however, can only be deciphered through a collective effort and from the complex standpoint of all those who suffer from it. When this collective emancipatory project asserts itself, calling the bluff of domination and its claims to exhaust the truth and potentialities of social life, then a different space begins tentatively to appear-a whole, healing, and democratic space for which we do not yet even know the proper name.

\section{Works Cited}

Agamben, Giorgio. Homo Sacer: Sovereign Power and Bare Life. Trans. Daniel HellerRoazen. Stanford, CA: Stanford University Press, 1998.

Apple, Michael W. Educating the "Right" Way: Markets, Standards, God, and Inequality. New York: RoutledgeFalmer, 2001.

Bauman, Zygmunt. Liquid Modernity. Cambridge, England: Polity, 2000.

Davis, Angela Y. Abolition Democracy: Beyond Empire, Prisons, and Torture. New York: Seven Stories Press, 2005.

Delgado Bernal, D. "Critical Race Theory, Latino Critical Theory, and Critical Raced-Gendered Epistemologies; Recognizing Students of Color as Holders and Creators of Knowledge." Qualitative Inquiry 8.1 (2002): 105-126.

De Lissovoy, Noah. "Rethinking Education and Emancipation: Being, Teaching, and Power." Harvard Educational Review 80.2 (2010): 203-220.

-. and Peter McLaren. "Educational 'Accountability' and the Violence of Capital: A Marxian Reading." Journal of Education Policy 18.2 (2003): 131-143.

Du Bois, W. E. B. Black Reconstruction in America. New York: The Free Press, 1935/1998. 
92 Noah De Lissovoy

—. The Souls of Black Folk. New York: Penguin Putnam, 1903/1995.

Fanon, Frantz. A Dying Colonialism. Trans. Haakon Chevalier. New York: Grove Press, 1965.

—. Black Skin, White Masks. Trans. C. L. Markmann. New York: Grove Press, 1967.

-. The Wretched of the Earth. Trans. Constance Farrington. New York: Grove Press, 1963.

Foucault, Michel. Security, Territory, Population: Lectures at the Collège de France, 19771978. Trans. Graham Burchell. New York: Palgrave Macmillan, 2007.

—. "Society Must Be Defended": Lectures at the Collège de France, 1975-1976. Trans. David Macey. New York: Picador, 2003.

Freire, Paulo. Pedagogy of the Oppressed. Trans. Myra Bergman Ramos. New York: Continuum, 1997.

Giroux, Henry A. The Abandoned Generation: Democracy Beyond the Culture of Fear. New York: Palgrave Macmillan, 2003.

- Youth in a Suspect Society: Democracy or Disposability? New York: Palgrave Macmillan, 2009.

Goldberg, David Theo. The Threat of Race: Reflections on Racial Neoliberalism. Malden, MA: Wiley-Blackwell, 2009.

Gordon, Lewis. R., ed. Existence in Black: An Anthology of Black Existential Philosophy. New York: Routledge, 1997.

Hardt, Michael and Antonio Negri. Empire. Cambridge, MA: Harvard University Press, 2000.

-. Multitude: War and Democracy in the Age of Empire. New York: Penguin Press, 2004.

Harris, Leonard. "What, Then, Is Racism?” Racism. Leonard Harris, ed. Amherst, NY: Humanity Books, 1999.

Harvey, David. A Brief History of Neoliberalism. Oxford: Oxford University Press, 2005.

—. The New Imperialism. Oxford: Oxford University Press, 2003.

Klein, Naomi. The Shock Doctrine: The Rise of Disaster Capitalism. New York: Metropolitan Books, 2007.

Maldonado-Torres, Nelson. Against War: Views from the Underside of Modernity. Durham, NC: Duke University Press, 2008. 
Marx, Karl. Capital. Trans. Ben Fowkes. London: Penguin Books, 1867/1976.

Mbembe, Achille. On the Postcolony. Berkeley: University of California Press, 2001.

\section{Notes}

1. David Harvey, A Brief History of Neoliberalism (Oxford: Oxford University Press, 2005).

2. Zygmunt Bauman, Liquid Modernity (Cambridge, England: Polity, 2000).

3. Henry A. Giroux, Youth in a Suspect Society: Democracy or Disposability? (New York: Palgrave Macmillan, 2009).

4. David Theo Goldberg, The Threat of Race: Reflections on Racial Neoliberalism (Malden, MA: Wiley-Blackwell, 2009).

5. Karl Marx, Capital, Trans. Ben Fowkes (London: Penguin Books, 1867/1976).

6. David Harvey, The New Imperialism (Oxford: Oxford University Press, 2003).

7. Kenneth J. Saltman, Capitalizing on Disaster: Taking and Breaking Public Schools (Boulder, CO: Paradigm Publishers, 2007).

8. Angela Y. Davis, Abolition Democracy: Beyond Empire, Prisons, and Torture (New York: Seven Stories Press, 2005).

9. Michel Foucault, "Society Must Be Defended": Lectures at the Collège de France, 1975-1976, Trans. David Macey (New York: Picador, 2003); Michel Foucault, Security, Territory, Population: Lectures at the Collège de France, 1977-1978, Trans. Graham Burchell (New York: Palgrave Macmillan, 2007).

10. Giorgio Agamben, Homo Sacer: Sovereign Power and Bare Life, Trans. D. HellerRoazen, (Stanford, CA: Stanford University Press, 1998).

11. See Michel Foucault "Society Must Be Defended."

12. Michael Hardt and Antonio Negri, Empire (Cambridge, MA: Harvard University Press, 2000); Michael Hardt and Antonio Negri, Multitude: War and Democracy in the Age of Empire (New York: Penguin Press, 2004).

13. Noah De Lissovoy and Peter McLaren, "Educational 'Accountability' and the Violence of Capital: A Marxian Reading," Journal of Education Policy, 18.2 (2003): 131-143.

14. See David Harvey, The New Imperialism; Naomi Klein, The Shock Doctrine: The Rise of Disaster Capitalism (New York: Metropolitan Books, 2007).

15. See Giorgio Agamben, Homo Sacer; Michel Foucault, "Society Must Be Defended"; Achille Mbembe, On the Postcolony (Berkeley: University of California Press, 2001). 
16. See Michel Foucault "Society Must Be Defended."

17. Charles W. Mills, The Racial Contract (Ithaca, NY: Cornell University Press, 1997).

18. W.E.B. Du Bois, The Souls of Black Folk (New York: Penguin Putnam, 1903/1995); W.E.B. Du Bois, Black Reconstruction in America (New York: The Free Press, 1935/1998).

19. Angela Y. Davis, Abolition Democracy.

20. Ibid.

21. Giorgio Agamben, Homo Sacer.

22. See W.E.B. Du Bois, Black Reconstruction in America.

23. Leonard Harris, "What, Then, Is Racism?” Racism, Leonard Harris, ed. (Amherst, NY: Humanity Books, 1999), p. 437-450.

24. Frantz Fanon, Black Skin, White Masks, Trans. C. L. Markmann (New York: Grove Press, 1967); Lewis R. Gordon, ed., Existence in Black: An Anthology of Black Existential Philosophy (New York: Routledge, 1997).

25. Michel Foucault "Society Must Be Defended."

26. See W.E.B. Du Bois, The Souls of Black Folk.

27. See David Theo Goldberg, The Threat of Race.

28. See W.E.B. Du Bois, Black Reconstruction in America.

29. C. J. Robinson, Black Marxism: The Making of the Black Radical Tradition (Chapel Hill, NC: The University of North Carolina Press, 2000).

30. Nelson Maldonado-Torres, Against War: Views from the Underside of Modernity (Durham, NC: Duke University Press, 2008); Walter D. Mignolo, The Idea of Latin America (Malden, MA: Blackwell Publishing, 2005).

31. David Harvey, The New Imperialism.

32. Frantz Fanon, The Wretched of the Earth, Trans. Constance Farrington (New York: Grove Press, 1963); Frantz Fanon, A Dying Colonialism, Trans. Haakon Chevalier (New York: Grove Press, 1965).

33. See W.E.B. Du Bois, The Souls of Black Folk; and W.E.B. Du Bois, Black Reconstruction in America.

34. See Michel Foucault "Society Must Be Defended."

35. Noah De Lissovoy, "Rethinking Education and Emancipation: Being, Teaching, and Power," Harvard Educational Review 80.2 (2010): 203-220.

36. Henry A. Giroux, The Abandoned Generation: Democracy Beyond the Culture of Fear (New York: Palgrave Macmillan, 2003). 
37. E.g., Michael W. Apple, Educating the "Right" Way: Markets, Standards, God, and Inequality (New York: RoutledgeFalmer, 2001).

38. Delgado Bernal, D., "Critical Race Theory, Latino Critical Theory, and Critical Raced-Gendered Epistemologies; Recognizing Students of Color as Holders and Creators of Knowledge," Qualitative Inquiry 8.1 (2002): 105-126.

39. Paulo Freire, Pedagogy of the Oppressed, Trans. Myra Bergman Ramos (New York: Continuum, 1997). 
Chapter 3

\title{
Neoliberalism, Environmentality, and the Specter of Sajinda Khan
}

\author{
ROBERT P. MARZEC
}

Two influential books were published in 1962: Rachel Carson's Silent Spring and Milton Friedman's Capitalism and Freedom. Friedman's policies of an unregulated market economy, economic individual rights, and a limited government have become the defining structure of planetary development for the course of the last thirty years. From the Reagan-Thatcher, then Clinton and Blair eras in the US and the UK; to the Hawke-Keating governments in Australia; to the Pinochet dictatorship in Chile; to Yeltsin in Russia; to Xiaoping in China, to Chrétien and others in Canada; and to nations in Europe, Africa, Latin America and elsewhere, neoliberalism is now the decisive planetary organizational force. The negative effects of the so-called Chicago School have been well documented. ${ }^{1}$ Constituted as an exceptionalist, end-of-history paradigm, its radical rejection of critical alternatives ushered in what Žižek has aptly termed the "post-political" era. ${ }^{2}$ On the other end of the spectrum, Rachel Carson's text ushered in a new critical awareness of ecological concern. The publication of her indictment of pesticides had a galvanizing effect, helping to generate an environmental movement that has expanded from the focus on chemicals toxins to various disciplinary efforts in the academy, and the increasingly comprehensive field of "ecocriticism" in my own field of literary studies. For the past five decades, these two areas of human production and concern have developed in a relatively autonomous fashion, although many environmentalists have been making the connection between capitalist economic policies and 
the destruction of specific environments. During this time, capitalism proceeded apace without any serious consideration for ecological concerns; conservatives, moderates, and libertarians tended to eschew, if not condemn outright, leftist and liberal pleas for a more sustainable lifestyle (barring the kind of lip-service found in green-friendly corporate advertising campaigns and institutionalized forms of environmentalism such as recycling and shop-for-a-better world entrepreneurship). This ostrichlike relationship on the part of neoliberals to the clear scientific evidence of global warming has begun to radically change in recent years-signaling, against its own structural desire, the logical self-destructive end of its essential character, and perhaps the first glimpse of the coming of the end of a monocratic economic paradigm.

That change can be defined as a new awareness of ecological necessity or eco-empiricism, one that has begun to draw attention away from economic production and development towards matters of national security. This eco-empiricism, as we shall see, is not the form of empiricism typically deployed to mount a convincing argument. As I will develop in this essay, it should more properly be understood as a new type of reproductive machine, one energized by state, military, and scientific authorities buttressing their activities on the futural event of environmental catastrophe. I define this machine's consumption of environmental catastrophe, specifically the event of climate change now under way, through the use of two critical theoretical terms: "environmentality" and "the Accidental" (which I will define in detail below). Environmentality, in turn, is the force now confronting the neoliberal State, and it is beginning to transform this reigning state formation into a new, more complex political apparatus: a formation I will call the Accidental State.

The stakes of unsustainable practices have changed since the publication of both Carson's and Friedman's works. The event of planetary climate change has globalized regional ecological concerns. Capitalism began, as I have argued elsewhere, in conjunction with an essential transformation in the human-ecological nexus. From its beginnings, it defined itself in opposition to Feudalism-specifically in terms of a "freeing" of the individual from the drudgery of the land (serfdom). The structure of this freedom was made possible through the national, then global, expansion of the enclosure movement, which turned a communal 
and a sustainable (subsistence) relationship to the environment into an entrepreneurial enterprise by privatizing land. Once ecosystems were privatized, nature became a source or "energy," on object needing to be "improved" and thus challenged to produce a "high yield," to use the old discourse of enclosure terminology). From its beginnings, Capitalism has depended for its existence and development on the establishment of an injurious relationship to nature. As individual entrepreneurship and national aspirations become more competitive, the relationship to nature becomes increasingly abusive. Planetary climate change is the logical selfdestructive conclusion of this economic form of anthropocentric development, revealing what capitalism looks like on the brink.

In 1988, the United Nations organizations of the World Meteorological Association and the United National Environment Program created the Intergovernmental Panel on Climate Change (IPCC) - a body of thousands of scientists voluntarily working to address the risk of planetary climate change in order to provide information for policymakers. In 2007, the United Nations (IPCC) released its fourth in a series of climate change reports. Entitled Climate Change 2007 and known officially as "The Fourth Assessment Report," the document is the product of 500 authors and the scrutiny of 2000 expert reviewers, representing over 50 nations and over a dozen international organizations. It confirms that global warming is "unequivocal," and that it is the result primarily of human activities, with the greatest output of greenhouse gases occurring between 1970 and 2004 (a 70 percent increase since pre-industrial times). ${ }^{3}$ The report was produced, in part, to give concrete authoritative advice to the international body established to address global warming - the United Nations Framework Convention on Climate Change. (The Framework Convention is the same body that produced the "Kyoto Protocol” in 1997.) Many of its projections are grim: by 2020 some 75 to 250 million people in Africa will be "be exposed to increased water stress"; in some African countries agricultural yields maybe be reduced by 50 percent; "water security" will intensify in southern and eastern Australia and New Zealand and water resources will decrease in sections of Africa, Asia, Europe, and elsewhere; agricultural yields in Latin American will be compromised; by mid century the eastern Amazonia 
forest will become a savanna; and there will be a significant loss of biodiversity in key geographical regions (such as the Great Barrier Reef).

One would think that such a report would have a profound effect on the ruling administration of social matters, not to mention public consciousness (and here I speak mostly of the economic policies of the neoliberal North and West). Even so, the majority of governing political structures and social discourses continue to thwart real efforts to legislate new environmentally-friendly policies - in part a symptom of the end-ofhistory, post-political age. The rhetoric of the report itself makes this clear. Despite the fact that the report describes itself as a "remarkable achievement," the product of "enthusiastic" and "dedicated" scientists devoted to providing scientific information to policy makers, it is also consciously framed by a series of enunciations emphasizing its apolitical naturestatements designed to alleviate any anxiety that the conclusions drawn and the suggestions made for policy makers might be contaminated by any particular political agenda. Moreover, the IPCC describes itself on its home page as an organization that produces information that is "policyrelevant" yet also "policy-neutral" and therefore "never policy-prescriptive." ${ }^{4}$ The standard scientific approach to such statements is to read them as non-political, in the sense of non-partisan-they are the result of the objective, and clearly important fact-oriented work of the scientist. The self-evident nature of the report means that it does not succumb to the limitations of any particular ideological vision of human ordering; it transcends all ideological agendas. The IPCC speaks to nations across the planet about the environmental crisis, now clearly visible as a worldwide phenomenon. It urges governments to work together. Academic theorizations of the political teach us to critique this apolitical emphasis. Such disclaimers, for instance, can be seen as reflecting a metaphysical neutrality that is ultimately too transcendental to speak to any particular nation, and any particular ecological problem (for instance, the problem of shore erosion in small islands in the Pacific and the problem of changing patterns in rainfall in North America cannot be handled in the same manner). Moreover, suggesting that "facts" have little to do with the business of prescribing changes to policy opens the door to the kind of hollow agreements such as the Kyoto Accord (which enabled wealthy nations in 
the north to continue their production of green-house gases unabated by "selling" their carbon credits to poor nations in the global south).

Such a pat reading, however, misses something crucial about the twofold ideological character of our contemporary global occasion-an economic system that has brought the planet to the brink of an ecological shift-that generates a gap between knowledge and desire. The report should more precisely be read as symptomatic of a larger structural problem, namely the inability to touch on the political (as an authentic act that breaks through the limitations of an established mode of existence). The report wishes to be political (like an ineffective desire running idle), yet somehow is caught within a neoliberal logical economy that assumes it should not be political (the essence of the Friedman school of knowledge production). To use the early postmodern terminology of Baudrillard, the report ends up being another example of the meaningless simulacra of "civilized debate" about climate change that ultimately produces no real threat to the status quo, despite its clear description of the urgency of our ecological occasion. In other words, this "knowing" by the IPCC that the report should not be political, buttressed by the unexamined coupling of the empirical/fact-oriented sciences to the apolitical, is a sign of a particular ontological and epistemological enclosure that governs social reality today. This is not a criticism of the IPCC; it is symptomatic description of the modern era's fear of the political.

In the modern era, however, one nation-state body can perhaps be openly politically engaged without having to deal with the stigma of being condemned as political. During George W. Bush's second term in office (a time when the White House openly denied global climate change) the Pentagon began to openly show a concern for the planet's environment. ${ }^{5}$ In 2004, the Pentagon urged the White House to begin to seriously consider the effects of climate change. After the publication of the "Fourth Assessment Report" the Pentagon began to use the report as the basis for a necessary transformation of our political reality. In March 2007, the Strategic Studies Institute of the US Army War College (SSI) held a conference on the topic "The National Security Implications of Global Climate Change," and produced a "Colloquium Brief” that argued the need for a "coordinated strategic communication plan" to inform and explicitly direct "public awareness." In 2008, the SSI published an edited 
volume of over four hundred pages entitled "Global Climate Change: National Security Implications." In July of 2007, the Center for Naval Analysis (CNA) - the Navy and the Marine Corp's federally funded research center-released its first major publication directly focused on the environment: "National Security and the Threat of Climate Change." The publication not only establishes the environment as a threat to global security, but links climate change directly to terrorism-on the basis that increased stress on resources will increase conflict. On July 27, 2008, the Center for a New American Security (CNAS) brought together 45 scientists, military strategists, policy experts, and business executives from Asia, South Asia, Europe, and North America to engage in a new type of military exercise: the Climate Change War Game. The exercise was supported by an extensive governmental, military, scientific, and business community, including the Brookings Institution, the Center for American Progress, the Center for Naval Analysis, the Heinrich Böll Foundation, McKinsey Global Institute, Oak Ridge National Laboratory, The Pew Center on Global Climate Change, the Rockefeller Brothers Fund, the Sustainability Institute, and Woods Hole Oceanographic Institution. ${ }^{7}$ Though it was not stated directly in the post-game analysis report, the goal of the game clearly was to convince the Department of Defense to take a new course of military action based upon the findings of the IPCC.

Such activity is becoming generalized. The highest authorities in the military and the Department of Defense have ramped up their military investment in climate change, producing, since 2007, a flurry of reports designed to convince state authorities and global economic organizations that they need to take the troubled ecological status of the earth seriously. ${ }^{8}$ Moreover, the military has begun to work openly with environmental scientists to address the issue of climate change. In 2012, the National Council for Science and the Environment (NCSE, the key political science organization recognized by state and military authorities) held its $12^{\text {th }}$ annual National Conference on Science, Policy and the Environment. The theme was "Environment and Security," and, in addition to leading members of the scientific community, the conference highlighted presentations by Sherri Goodman (Executive Director of the Center for Naval Analysis (CNA) Military Advisory Board), Vice Admiral Lee Gunn (President of the CNA's Institute for Public 
Research), Rear Admiral David Titley (director of the Navy's Task Force on Climate Change), Major General Muniruzzaman (President of Bangladesh's Institute of Peace and Security Studies), Marcia McNutt (Director of the US Geological Survey), Nancy Sutley (Chair of the White House Council on Environmental Quality), Rear Admiral Neil Morisetti (Commander UK Maritime Force and the UK government's Climate and Energy Security Envoy), and a host of others. In addition, key economic players such as the IMF and the World Bank now openly expressed their concern for climate change. In 2008, president of the World Bank Robert Zoellick stated that the world is one harvest away from a global catastrophe.

Nonetheless, this neomilitary activity has yet to crack through the simulacra of climate change "doubt" that currently engulfs the public arena and forestalls any real political change. Here it is important to recognize the isomorphic power of this arena, generated by its post-political essence: namely, the ability to entertain differential sources of information and points of view while still maintaining the status quo. Here, the argument that would presumably change the coordinates of existence (what would amount to a real political act, according to Jacques Rancière) is effectively reduced to a particular agenda recognized immediately as "specialist" and therefore untrustworthy and requiring critical suspicion of a kind that can only come from an unbiased, apolitical mind. The IPCC, for instance, must confront the extreme pressures put on its findings over the course of the last fifteen years by conservative politicians, fossil-fuel dependent corporations, and think tanks supported by oil companies such as the George C. Marshall Institute (whose scientists directly deny any scientific evidence of human-caused warming). To recall a few of the instances, in 1995 the Institute reported in the Wall Street Journal that a key scientist working for the IPCC deliberately cleansed uncertainties from his findings to make global warming appear more indisputable. The accusation was proven to be false, but the impression that the IPCC could not be trusted remained, which only further solidified the hegemony of the fiction that global warming may be a hoax. ${ }^{9}$ Less conservative media outlets such as CNN and MSNBC indirectly add fire to this fiction in and through their tendency to report on the IPCC almost only when a "controversy" arises: e.g., the "Climategate" scandal of 2009, when over 
a thousand emails from the IPCC's affiliate the Climate Research Unit of East Anglia University were illegally obtained by anti-climate change advocates. The statements made by researchers in the emails were taken out of context and used to "prove" that IPCC scientists were falsifying information to support their claims. ${ }^{10}$ Again, the IPCC was vindicated in these same media outlets, but the mistrust for its scientists was only magnified. This discursive play of controversy was enhanced by views from alternative, leftist media sources - with the same result. Each new vindication of the IPCC only generates more "smoking guns," more suspicion, and consequently more "dialogue" that further obscures any and all ability to make distinctions. The introduction of empirical evidence into this dialogic play, therefore, is absolutely innocuous. At best, such an approach can only support the ineffectual need to achieve an agreeable "consensus," in which all points of view are given equal merit, ensuring that the overarching needs of the very market forces that threaten environments continue unchecked.

Thus the most resistant and clear-headed empiricist representationeven when generated by a vast apparatus of experts - actively participates in the pacifying field of representation that maintains the framework of existing political practices. More to the point, this interminably protracted diversification of "opinions" should be thought properly against the horizon of capitalist neoliberal globality that creates its conditions of possibility. Despite the fact that each representation is weighted with significance, in the multi-viewpoint economy of neoliberal democracy, in which each representation is "given its share," rationality and empiricism can only ensure that this agitation is maintained. The continual production of agitation becomes an end in itself, transforming even the emancipatory agency that presumably comes from criticism and skepticism into the essential subsidizing force of existing relations. Hence, a narrative that would directly break through this protraction-such as the empirical Real of global warming that cannot be fully admitted in a profit-oriented structural economy-is entirely deprived of any performative force. Empiricism is crippled by its own indisputable ontic evidence, which is a key reason why this approach does not even come close to uncovering the ontological ground that constitutes the preset stage of this theatricalized debate. 
It should be noted that this post-Cold War militarization of ecology links security to environmental matters at the global level, directly in and through the foregrounding of insecurity (planetary climate change, for instance, is frequently described as the successor to the insecurities of post-9/11 terrorism). The regulatory mechanisms of this militarized environmentalism operate according to the deployment of global environmental catastrophe: rising sea levels that will effect all national borders; the increasing stress put on border control by the movement of millions of "climate change refugees"; shifting weather patterns that will lead to drought and subsequent water and food insecurity; etc. The staged activity of this insecurity has begun to overshadow the many local/regional ecological concerns that, for years, defined the environmental movement and its struggles. Consequently, the new "environmentalism" beginning to define the political field of the early twenty-first century (once that field is politicized again), is a militarized environmentalism, one that overlooks the complexities of local concerns, not to mention the philosophical work of generating new conceptual human-nature relations.

A more critical strategy might begin to shed light on the planet's various actors occluded by this globality and its illuminated terrain. For instance, very little media attention was given to a different form of environmental activism that uncannily paralleled the two decade-long operations of the IPCC. For instance, very little media attention was given to a different form of environmental activism that uncannily paralleled the two decade-long operations of the IPCC. It was uncanny because it directly conflicted with the precise manner in which the concerns of the IPCC became actualized as policy and substantially recast within the neoliberal paradigm (the Kyoto accord and carbon trading are the prime examples). The primary intermediary of this activism was a woman by the name of Sajida Khan, a South African Indian Muslim and political activist who spent the majority of her life in a struggle for a livable and ecologically-sound habitation. Khan fought first against the racial injustices of apartheid, then against the post-apartheid ecological climate policies of the Kyoto accord that paradoxically ensured that a toxic landfill would continue to fully function literally across the street from her house in Durban, South Africa. Known as the Bisasar Road landfill, it is South Africa's largest formal garbage dump, which was created by apartheid 
bureaucrats in 1980 on the site of what was formerly a nature reserve in a mixed-race neighborhood. The Bisasar Road site is one of the most active landfills. It substantially exceeds the limits of waste emissions considered to be hazardous: "hydrogen chloride by $50 \%$, cadmium by $200 \%$, and lead by more than $1000 \%$." 11 Sewage slug is dumped at the site on a daily level - a direct violation of South Africa's water law, which requires that sewage be transported and disposed of so as not to cause a hazard. ${ }^{12}$ The decomposition of the landfill's waste produces heavy concentrations of methane, benzene, toluene, trichloroethylene, and formaldehyde. Each of these poses both short-term and long-term problems. Benzene, for instance, causes dizziness, tremors, confusion, unconsciousness, and death if experienced in a high enough dose. Long-term exposure to high levels of benzene in the air, according to the Department of Health and Human Services, can cause leukemia. Women in particular who live near landfills have a four-fold increased susceptibility to cancer (Khan herself died of cancer in 2007). ${ }^{13}$ A survey found that seven out of ten households in the area reported cases of tumors. The government promised to close the dump in 1987, but it continues to function to this day.

In 2002, a team from the World Bank met with Durban officials and, under the official carbon-trading credits system of the Kyoto accord, convinced local officials to keep the landfill open an additional 7 to 20 years. Carbon trading is one of the "realistic solutions" to climate change generated by global capitalism (the idea was written into the accord by the United States, before it backed out from signing the agreement). It essentially turns ecological protection into eco-prostitution. The carbontrading credits systems functions as follows: The Kyoto accord requires that nations across the planet reduce a certain percentage of their carbon output. It recognizes at the same time that developing countries do not necessarily have the wealth and infrastructural means to transform their environmental practices to meet these reductions. Thus the burden of ecological change is supposedly put on the wealthy nation (which typically produces more CO2s/greenhouse gases). However, if a wealthy nation does not want to meet this requirement it can buy "carbon credit" from a less wealthy nation by helping that nation reduce its greenhouse gas production. This has all the appearance of colonization turned on its head, with a colonial authority deploying "green" standards 
of existence it refuses to meet at home on its peripheral colonies. This is why the Bisasar Road landfill is so "productive" to keep open. The toxins the landfill produces are a "clean development mechanism": the methane it radiates can be reclaimed so as to produce electricity, which is a more "environmentally sound" method than, say, coal (which produces greenhouse gases). For this reason, nations in the north financially support the Bisasar methane-to-electricity project because of its reduction of greenhouse emissions. In this way a northern nation can continue its high level of greenhouse gas production at home, and still meet the required percentage of reduction set by the Kyoto accord by buying carbon "credit" from abroad.

Sajita Khan's struggle for a livable inhabitancy is symptomatic of a fundamental limitation that rules in today's world of geopolitics - a framework that I define according to an organizational machine that I refer to as "environmentality." "Environmentality," like Foucault's governmentality, refers to the structural administration of environmental matters by state organizations, the neomilitary machine, and corporate-global actors. The term is designed to show the indissoluble relation to the increasing control of public life by military modes of thought and structures of existence. Environmentality thus names the generation of scientific and state environmental authorities within militarized paradigm, in turn buttressed by the machine of neoliberal economic globalization. The complex and unpredictable flow of multinational and transnational corporate and speculative capital thus works in tandem, not against, this ecological war machine. The two are interrelated, and can be defined in part as the return of a certain coloniality that controls the flow of energy resources, creating monumental inequalities between the nations of the North and the West over the South and near East, and unforeseen financial and ecological impoverishments in all countries.

In this framework, both universalizing forces of apolitical disinterest and particular forces of brutal, local essentialism work in tandem and define the terrain of human possibility. This terrain is divided geographically. Universalizing forces predominate in the north and westareas presumed to exist in the advanced state of the "end of history," where wars and essentialist political struggles have supposedly disappeared. In these regions, human subjectivity is not constituted in terms 
of ecological habitations but along the complex and paradoxical lines of a sovereignty that controls and encloses but also transcends all habitations. This sovereign subjectivity is fluid and mobile, and not tied to any particular identity (racial, ethnic, etc.). In this sense it is "developed" and "exceptionalist." It is the offspring of the imperial subject, yet unlike the essentialist identity of its near ancestor, its adaptable identity is "speculative" (in a primarily economic sense). Hence, it is also subject to the uncertainties of a global geopolitical economy. In opposition stands the subject of developing countries. This form of subjectivity is identified (by the exceptionalist subject) in terms of its passionate and essentialist connection to a particular habitation or ecosystem. This subjectivity remains mired in the colonial and postcolonial history and political struggle that marks underdeveloped regions (ethnic identities associated with specific geographical regions; indigenous populations underrepresented by the States that surround them; racial identities associated with particular neighborhoods). The neighborhood of Bisasar, for instance, has its origins in the racist and military practices of Apartheid-in an imperial, essentialist conception of the land based on the discourse of blood-andsoil politics that marks so much of twentieth-century world affairs. The tendency of planetary organizations to supersede the needs of local differences, coupled with the instability generated by the speculative logic of late capital only supports the increase of these essentialist claims: the blood-and-soil position thus arises directly in relation to the fluidity of exceptionalist, apolitical forces. They are two sides of the same coin.

The complexities of these forces need to be taken into account when analyzing the various and growing struggles for inhabitancy in our current historical occasion, such as Khan's. For starters, we should be careful not to condemn the impact of the Kyoto accord on the Bisasar landfill as a sign of government hypocrisy (the typical libertarian stance). Instead, we need to diagnose it as symptom of the founding foreclosure that defines today's new radical neoliberalism - a neoliberalism defined less by economic necessity than by the empirical necessity of national security (in the ecological forms of "energy security," "food security," and "water security"). This foreclosure is difficult to uncover, for it is mystified in the way we (mis)perceive reality in terms of the tension outlined above: between "global" administrative orders (that present themselves as disinterested 
and non-partisan) and the "local" desires of particular communities and individuals (who are seen as fully enmeshed in their special concerns and interests, and therefore less able to intervene "objectively" in matters of policy). The carbon-trading system is an attempt to keep the struggle for environmental change literally off the ground, by overlooking the antagonistic "essence" of this "ground" in principle. Being "off the ground" is constituted as liberatory (postmodern and post-political). It is made possible by the idea of being "on the ground," which is deployed as a disease of the historically arrested. It is one of the key ways that an erasure of an alternative to either the essentialist or the speculative conception of geography is inscribed into the very system of globality in which the Kyoto agreement participates. It is also the same globality to which many environmentalists unwittingly subscribe.

In addition, underdeveloped national administrations more often than not fully support their transnational counterparts in maintaining this global framework. South Africa's Department of Environmental Affairs and Tourism's climate change "response strategy" states that "clean development mechanisms" (such as the Bisasar landfill) present "a range of commercial opportunities" and an "important source of foreign direct investment." ${ }^{14}$ What this unabashed neoliberal calculus of human lives reveals - in its direct, even ruthless disrespect for the "other"-is a waning of postmodern political correctness in favor of a neoimperial structure of marginalization that feels no need to give the slightest lip service to the struggles of disenfranchised peoples. My key claim here is that this neoimperial structure functions by mobilizing a fear and orchestrating a patent dismissal of any and all attempts to conceptualize and actualize a philosophy of inhabitancy - that is, a realization of the human (and the nonhuman) from the standpoint of a fundamental right to a habitation. Instead, human subjects are either formed as deputies and attendants in relation to what might be called "above-surface" structures-corporate transnational agencies, global governance bodies, international judicial systems - or they are fashioned as dispensable, nonessential remainders stripped of all rights and liberties, capable of being displaced whenever the fluctuations of market forces or the new policies of an administrative order deem it necessary. 
These complex forces manifest themselves in terms of a generalized war against land that involves the coconstitutions of 1) a no-man's land and landless peoples, 2) a new understanding of geography based on a militarized "omni-surveillance," and 3) new conception of nature. The last of these involved the reconceptualization of nature in terms of "energy," which in the $21^{\text {st }}$ century is grounded in the military problematic as "energy security." "Energy security," which was always operative in a mode that is more properly defined as colonial during the $17^{\text {th }}$ to the $20^{\text {th }}$ centuries, is now in the process of reaching its logical conclusion, in the sense of its uttermost fulfillment on a global scale. The military ecological maneuvers listed above reflect this reconstellation of nature within the discourse of energy security. Another sign is the recent concern for environmental causes on the part of neoconservatives in the US-organizations such as the Green Patriots and the Set America Free Coalition that wish to reterritorialize entire ecosystems in terms of their potential as non-petroleum sources of energy. Robert Zubrin's 2007 book Energy Victory: Winning the War on Terror by Breaking Free of Oil-in which he makes the case for essentially the total enclosure of practically all thirdworld agricultural communities in order for the first world to make the transition to alcohol-based fuels-is exemplary in this aspect. Zubrin's argument is based on the fact that the crop base for producing methanol includes "all plants, without exception": "Not only the edible and inedible parts of commercial crops, but weeds, wild jungle underbush, trees, grasses, fallen leaves and branches, water lilies, swamp and river plants, seaweed, and algae, can all be used to produce methanol.... By switching to alcohol we could quadruple our purchases of third world agricultural goods.... A huge engine for world development would thus be created." ${ }^{15}$ Thus the various critical signifiers that disclose the truth of the many threats to the planet's ecosystem are being overwritten and erased by the single conservative allotrope "US Energy Security." Here, the land and its inhabitants - the human and the non-human - come to presence in the neoliberal paradigm as a military problem. Reorganized in this new stratocracy, environmental activism is thus co-opted and managed in an environmentality that reigns over human and nonhuman existence, with little concern for the specifics of ecological habitations and their nonhuman and human inhabitants. 
This, finally, leads me to central organizational mechanism that enable the threefold combination of neoliberalism, the military machine, and the environment-a mechanism I would like to identify with the critical conceptual name of "the Accidental." The Accidental is a term that combines Kant's concept of the transcendental and Paul Virilio's "accidental thesis." In his work on ecology, Virilio has identified a much longer historical relation between the military and ecological concerns. Part of the military's approach to ecological concerns relates to late modernity's mandate to expose and fully explain the totality of existence:

$[\mathrm{I}] \mathrm{n}$ a world which is now foreclosed, where all is explained, the accident is what remains unexpected, truly surprising, the unknown quantity in a totally discovered planetary habitat, a habitat over-exposed to everyone's gaze, from which the "exotic" has suddenly disappeared in favour of [the] "endotic." 16

Virilio's thesis is that this drive to "overexpose" for purposes of total control, technological manipulation, and economic development (typified by the high-yield demand of economic liberalization and the subsequent military need to secure these developed environments) creates a world of increasingly dangerous and globally-consequential accidents: from flight disasters to Chernobyl to the unexpected outcomes of the genetic manipulation of crops. Virilio's name for this is "the accident thesis." ${ }^{\text {"17 }}$ It characterizes how increased pressure to overcome obstacles to the production of high-yields through technological manipulation creates an increased potential for accidents to occur. In a "totally discovered and overexposed habitat" - an asphyxiating version of "the end of history"the potential for transcendence disappears and is replaced by the different form of a "breakage of/from the system": the accident. Developing this idea, I argue that transcendence from the disciplinary confines of context becomes increasingly impossible; it is replaced by acid-enceforms of momentary breakdown that only occur within and because of the system, not breakdowns that radically open a free space for the potential to restructure the system. It is in and through the Accidental that environments are militarized. 
To give an example of full global enclosure and exposure, and the erasure of any potential to transcend context: the colonization of the environment for military purposes reaches its full development in the $20^{\text {th }}$ century, even before the environment became an issue in public consciousness with the publication of Carson's Silent Spring. It was during the post WWII Cold War nuclear experiments by the US military industrial complex that ecology became a field of study in the university system. The Atomic Energy Commission created the field of "radiation ecology," which began with the study of effects of militarized radioactivity on the environment around the Pacific island of Bikini Atoll. As Elizabeth DeLoughrey so powerfully documents, the establishment of this field began with the hundreds of nuclear tests conducted in what was known as the "Pacific Proving Grounds." To name two: the H-Bomb Mike was dropped in 1952 and blew the island of Eugelab out of existence. According to DeLoughrey, at 10 megatons (700 times the explosive force of the bomb dropped on Hiroshima), Mike's radioactive fallout was measured in rain over Japan, in India, and in the US and Europe. Two years later, the next bomb dropped increased this yield to 15 megatons. A scientist working for the AEC declared in 1954 that after just two years of testing, that all humans on the planet now had "hot" strontium in their bones and teeth and "hot" iodine in their thyroid glands: "Nobody believed you could contaminate the world from one spot. It was like Columbus when no one believed the world was round.” In 1958, the US, UK, and USSR exploded nearly 100 nuclear weapons, leading to record levels of strontium-90 in American soil, wheat, and milk. Total control through targeting leads to the accident of total exposure and the impossibility for any human to transcend this contamination.

In this erasure of the transcendental in favor of the accidental, our access to ecology changes fundamentally. Instead of "ecology" or "environmentalism" we now have environmentality. In addition to the definition I've given this term above, we can now see that this discourse of environmentality combines 1) neoconservative efforts to pass legislation for the control of third world agricultural communities in key geographical regions across the planet; 2) the changing status of neoliberalism and its "concern" for the environment; and 3) the shift on the part of the State and its corporate supporters from a focus on the constitution of human 
subjects in terms of biopower to a focus on the environment as an ecopower that ultimately trumps human subjectivity (for instance, the attention paid by military and state actors to the coming catastrophe of climate change manifests itself most strongly in terms of the climate change refugee category-of the near-future migration of millions of people across the planet currently living in coastal regions and on island nations that will eventually disappear by 2050). The diversity operative in traditional liberalization is now giving way to a form of diversity evacuated of any political agency and cultural content (it does not matter which culture appears as the next accident—all cultures are equal and equally reduced as accidents, and are only accepted as such).

Manipulation can thus be addressed more critically (i.e. outside dominant theories of sovereignty) in terms of the lines being drawn between corporate/State flows of power and ecosystemic developments - namely the corporate, judicial, and legislative alliances being formed around the struggle for diminishing resources, and the impending shift to nonpetroleum sources for global mass transportation and global mass consumption. Though the State is part of this shift, it and the cultural socius lag behind the direct activity of what should be understood properly as the developing Accidental State-a structure composed of environmental organizations, State and corporate officials, security institutes, centers for foreign and domestic policy, private companies, and the military.

We can extend Virilio's work here by first drawing a firm connection between the accident, the environment, and what I have referred to elsewhere as the war on inhabitancy. The event of the Love Canal disaster in the US, which galvanized a specific environmental awareness and movement, is one example of an "accident" that irreparably damaged an environment and its inhabitants. But the accident is more firmly connected, even embedded now, in the planet's ecosystems in the late enclosing age of postmodernity, as we can see in the overproduction and subsequent destruction of ecosystems for today's high yield-oriented profit system. The capitalist technological manipulation of land that defined the Green Revolution in the Punjab is symptomatic of an "overexposing" of land that leads to the "accident" of excess salinity and waterlogging. This in turn leads to the "accident" of mass hunger and a global decrease in calorie intake. The push to monocrop by transnational corporations turns food 
into a commodity for sale on the international market. Monocropping eliminates the chances of a community to fall back on locally produced food and forces the community to pay for food produced elsewhere. When an "accidental" dip occurs in the market, agricultural workers' pay drops and communities already underpaid find themselves in the position of having no money to buy food. The struggle to survive produces the "threat" of encroachment by these communities in forests and privatized farmland. This in turn requires the transformation of nature into "threatened" nature, which in term produces legislation that represents nature as a being in need of "environmental protection." In the ontology of the accidental humans are constituted in terms of their ability, and consent, to "protect" the environment (in other words, securing the highest yield of energy). For bad subjects and the poorest of humans, especially those working in the worst possible conditions in agricultural communities in the third world, the shadow humans that make the north and the west possible, they are increasingly seen as a threat to the environment, and to this new environmentality. ${ }^{18}$

The massacre of Marichjãpi in the Sundarbans of India is another example. In the aftermath of Partition, low-caste and impoverished refugees from the war, Dalites, moving from East Pakistan into India, were taken to locations outside of West Bengal. The refugees resettled in what were called Permanent Liability Camps that were surrounded by barbed wire and guarded. With the encouragement of the CPI(M) party (before it came to power in 1978), the refugees organized an escape and made their way toward the east in the hope of settling in the area of the Sundarbans. In a place where there had been no inhabitants before there were now thousands, almost overnight. Once the Leftist government came to power, however, they began to recast the refugees' plight by transforming them from a people struggling to find a habitation into a "threat" to the Sundarban environment, which subsequently led to their forced eviction and massacre. This transformation was in part the responsibility of the party itself, which originally spoke on behalf of the refugees, but ultimately used them for gaining a broader support base. In the wake of these events the human and the nonhuman were posed as mutually-exclusive problems to a state caught within the accidental problematic, and when one problem entered the domain of the other the 
"solution" could only be a destructive one: the "accident" of encroachment and subsequent violent "accident" of forced eviction and massacre. These and similar events-environmental disaster and human excessare now coproduced by the State within the ontology of the accidental. The result is that threatened environments unavoidably contribute to the endotic logic of closing humans off from their ability to inhabit the land.

This increase in the number of accidents (catastrophes) defines human culture and its environment at the level of its being in our current historical occasion and plays a role in the way our minds constitute Third World environments as objects of investigation and use. The foreclosure of encounters with anti-systemic phenomena brought about by the occasion of "overexposure" (the total enclosure of the heterogeneous being of nature as monocrop-commodity; the submerging of geographical differences and distances under the signifier "space" so as to transform it into an obstacle for technology to overcome in favor of "speed" and "immediacy") repositions the appearance of the unexpected from the exterior to the interior. Hence the unexpected begins to appear as an internalized accident. It is paradoxically surprising but also expected. The foreclosed system of the Accidental puts people on the alert for accidents, generating a state of hyperactive awareness. The accident thus offers no transcendence from the system, and on this basis can be named the accidental. The accidental names a world in which events - the struggles of constituents and their environments that emerge in the media-can only appear in the form of accidents. It evacuates the political sphere of both national sovereignty and citizen sovereignty.

Thus a peculiar ontological understanding of the world rules relations between humanity and the environment today_made manifest by this glut of symbolic investiture in popularized eco-political polemics. This ontology makes the possibility of inhabitancy on our planet-for both humans and non-humans-increasingly untenable. The Accidental is thus the name for a specific status of humans and the environment. ${ }^{19}$ It is the nature of the Accidental, to co-opt both the life struggles of poor communities and threatened habitats. It is highly mobile and freefloating, shifting incessantly in its chase for the next accident. It incites a certain form of heterogeneity, and in this sense is decentered and postmodern. It parallels the logic of the contemporary occasion of neoliberalism, 
variously called "post-Fordism," "late capitalism," "flexible accumulation," "bare life," "empire" after colonial imperialism, etc. As such it cannot be located within any classical notion of national sovereignty, though the nation is still retained as a part of the functioning of the accidental. But the accidental evacuates the political sphere of both national sovereignty and citizen sovereignty. A certain form of political conservatism still operates within this liberal structure, but this mainly functions in order to manipulate public opinion by directing it toward the next impending accident: it is a form of terrorism directed at all. What we are thus seeing is the coming of the end of neoliberalism as we know it. Friedman's ideal form of human (non)political existence is being replaced by environmentality - a new form of human ontological existence that foregrounds the environment not as space for the development of new, non-anthropocentric relations and modes of production, but as a threatening space, as the space of catastrophic insecurity. In turn, this ontology is being administered through its co-constituent structure - the Accidental State-which has begun to replace former nation-state structures and transform the developmental economy of the neoliberal state.

\section{Works Cited}

Armstrong, Paul. “Q\&A: 'Climategate' Explained." CNN World. http://www.cnn. com/2010/WORLD/europe/07/07/climategate.emails.explainer/index.html

Blank, Stephen J. “Russia in the Arctic." Strategic Studies Institute (July 2011).

Burke, Sharon and Christine Parthemore. Climate Change War Game: Major Findings and Background. Center for a New American Security. (June 2009). http://www. cnas.org/files/documents/publications/Climate_War_Game_Working Paper_0. pdf

The Center for Naval Analysis Corporation. "National Security and the Threat of Climate Change.” 2007. https://www.cna.org/reports/climate

Chomsky, Noam. Profit Over People: Neoliberalism and Global Order. New York: Seven Stories Press, 1998.

DeLoughrey, Elizabeth. "Radiation Ecologies and the Wars of Light." Modern Fiction Studies 55:3 (Fall 2009): 468-495. 
Department of Environmental Affairs and Tourism. "A National Climate Change Response Strategy for South Africa.” 2004. http://unfccc.int/files/meetings/ seminar/application/pdf/sem_sup3_south_africa.pdf

"Facts About Benzene." Centers for Disease Control and Prevention. http://www.bt.cdc. gov/agent/benzene/basics/facts.asp

Harvey, David. A Brief History of Neoliberalism. Oxford: Oxford University Press, 2005.

International Panel on Climate Change. Climate Change 2007: Synthesis Report. Contribution of Working Groups I, II, and III to the Fourth Assessment Report of the Intergovernmental Panel on Climate Change. Core Writing Team, R.K. Pachauri, and A. Reisinger, eds. Geneva, Switzerland. [Formerly http://www.cnn. com/2010/WORLD/europe/07/07/climategate.emails.explainer/index.htm]

—. “Organization.” http://www.ipcc.ch/organization/organization.htm

Johnson, Douglas V., II. “Global Climate Change: National Security Implications.” US Army War College and Triangle Institute for Security Studies. May 1, 2007.

Leestemaker, Joanne Heyink. "An Analysis of the New National and Subnational Water Laws in Southern Africa." The Water Page. http://www.africanwater.org/ leestemaker.htm

Major Economies Forum. Technology Action Plan: Report to the Major Economies Forum on Energy and Climate (December 2009).

Oreskes, Naomi and Erik M. Conway. "Attack on Climate Scientist Just Latest in a Long Line.” CNN Opinion (10 June 2010). http://www.cnn.com/2010/ OPINION/06/07/oreskes.climate.change/index.html

Pataki, George E. and Thomas J. Vilsack. Confronting Climage Change: A Strategy for US Foreign Policy. Independent Task Force Report No. 61. New York: Council on Foreign Relations, 2008.

Pumphrey, Carolyn, ed. “Global Climate Change: National Security Implications.” Strategic Studies Institute. May 2008. http://www.strategicstudiesinstitute.army. $\mathrm{mil} / \mathrm{pdffiles/pub862.pdf}$

Reddy, Trusha. "Durban's Perfume Rods, Plastic Covers and.” Carbon Trade Watch. http://www.carbontradewatch.org/index.php?option=com_content\&task=view \&id $=180$ \&Itemid $=36$

Sen, Amartya. Development as Freedom. Oxford: Oxford University Press, 1999. 
Taylor, James J. “Former IPCC Leader Says Alternative Group Needed.” Environment and Climate News (April 2010). http://www.heartland.org/ environmentandclimate-news.org/article/26939/Former_IPCC_Leader_Says_ Alternative_Group_Needed.html

Townsend, Mark and Paul Harris. "Now the Pentagon Tells Bush: Climate Change Will Destroy Us." The Guardian (21 February 2004). http://www.theguardian. com/environment/2004/feb/22/usnews.theobserver

US National Intelligence Council and the EU Institute for Security Studies. Global Governance 2025: At a Critical Juncture (September 2010).

Virilio, Paul. Popular Defense and Ecological Struggles. Trans. Mark Polizzotti. New York: Semiotext(e), 1990 [1978].

—. Unknown Quantity. London: Thames \& Hudson/Fondation Cartier, 2003.

Žižek, Slavoj. The Ticklish Subject: The Absent Centre of Political Ontology. London: Verso, 1999.

Zubrin, Robert. Energy Victory: Winning the War on Terror By Breaking Free of Oil. Amherst, New York: Prometheus Books, 2007.

\section{Notes}

1. See especially, Amartya Sen, Development as Freedom (Oxford: Oxford University Press, 1999); Noam Chomsky, Profit Over People: Neoliberalism and Global Order (New York: Seven Stories Press, 1998); and David Harvey A Brief History of Neoliberalism (Oxford: Oxford University Press, 2005).

2. Slavoj Žižek, The Ticklish Subject: The Absent Centre of Political Ontology (London: Verso, 1999), esp.p. 171-244.

3. International Panel on Climate Change, Climate Change 2007: Synthesis Report. Contribution of Working Groups I, II, and III to the Fourth Assessment Report of the Intergovernmental Panel on Climate Change [Core Writing Team, R.K. Pachauri, and A. Reisinger, eds.], (Geneva, Switzerland). In 2010, the IPCC came under fire when conservative organizations stole emails from one of its key research centers, the Climate Research Unit of the University of East Anglia. Statements within the emails were taken out of context by conservative organizations and misread to dispute the authenticity of the report. Only one particular statement made in the Fourth Assessment Report has been found to be questionable, that the Himalayan ice cap will melt by 2035 . The IPCC has publicly admitted the questionability of this finding. Despite this, the report has failed to produce any agreement on the part of organizations to broke a global deal on climate change. See 
http://www.cnn.com/2010/WORLD/europe/07/07/climategate.emails. explainer/index.html

4. International Panel on Climate Change, "Organization," http://www.ipcc.ch/ organization/organization.htm.

5. Mark Townsend and Paul Harris, "Now the Pentagon Tells Bush: Climate Change Will Destroy Us," The Guardian (21 February 2004). http://www. theguardian.com/environment/2004/feb/22/usnews.theobserver.

6. Carolyn Pumphrey, ed., "Global Climate Change: National Security Implications," Strategic Studies Institute, May 2008. http://www. strategicstudiesinstitute.army.mil/pdffiles/pub862.pdf

7. Sharon Burke and Christine Parthemore, Climate Change War Game: Major Findings and Background, Center for a New American Security (June 2009). http://www.cnas.org/files/documents/publications/Climate_War_Game Working Paper_0.pdf. Burke is the Vice President for Natural Security at the Center, and Parthemore is the Bacevich Fellow at the Center.

8. A brief survey would include: "National Security and the Threat of Climate Change," The Center for Naval Analysis Corporation, 2007; George E. Pataki and Thomas J. Vilsack, Confronting Climage Change: A Strategy for US Foreign Policy, Independent Task Force Report No. 61. (New York: Council on Foreign Relations, 2008); Douglas V. Johnson II, "Global Climate Change: National Security Implications," US Army War College and Triangle Institute for Security Studies, May 1, 2007; US National Intelligence Council and the EU Institute for Security Studies, Global Governance 2025: At a Critical Juncture, September 2010; Stephen J. Blank, "Russia in the Arctic," Strategic Studies Institute (July 2011); Major Economies Forum, Technology Action Plan: Report to the Major Economies Forum on Energy and Climate, December 2009.

9. Naomi Oreskes and Erik M. Conway, "Attack on Climate Scientist Just Latest in a Long Line," CNN Opinion (10 June 2010). http://www.cnn. com/2010/OPINION/06/07/oreskes.climate.change/index.html. See also: James J. Taylor, "Former IPCC Leader Says Alternative Group Needed," Environment and Climate News (April 2010). http://www.heartland.org/ environmentandclimate-news.org/article/26939/Former_IPCC_Leader_ Says_Alternative_Group_Needed.html

10. Paul Armstrong, "Q\&A: 'Climategate' Explained," CNN World. http:// www.cnn.com/2010/WORLD/europe/07/07/climategate.emails. explainer/index.html

11. Trusha Reddy, “Durban's Perfume Rods, Plastic Covers and," Carbon Trade Watch, http://www.carbontradewatch.org/index.php?option=com_content\& task $=$ view\&id $=180 \&$ Itemid $=36$ 
12. Joanne Heyink Leestemaker, "An Analysis of the New National and Subnational Water Laws in Southern Africa," The Water Page. http://www. africanwater.org/leestemaker.htm

13. "Facts About Benzene," Centers for Disease Control and Prevention. http:// www.bt.cdc.gov/agent/benzene/basics/facts.asp

14. Department of Environmental Affairs and Tourism, "A National Climate Change Response Strategy for South Africa,” 2004. http://unfccc.int/files/ meetings/seminar/application/pdf/sem_sup3_south_africa.pdf

15. Robert Zubrin, Energy Victory: Winning the War on Terror By Breaking Free of Oil (Amherst, New York: Prometheus Books, 2007), p. 147.

16. Paul Virilio, Unknown Quantity (London: Thames \& Hudson/Fondation Cartier, 2003), p. 129.

17. Ibid., p. 129.

18. See Elizabeth DeLoughrey, "Radiation Ecologies and the Wars of Light," Modern Fiction Studies 55:3 (Fall 2009): 468-495.

19. For the relationship on speed and space, see Paul Virilio, Popular Defense and Ecological Struggles, Trans. Mark Polizzotti (New York: Semiotext(e), 1990 [1978]), p. 28-36. 
Chapter 4

\title{
Rhetorical Assemblages \\ Scales of Neoliberal Ideology
}

\author{
JENNIFER WINGARD
}

This spring in Texas, Rep. Debbie Riddle proposed House Bill 2012, which sought to fine or imprison ${ }^{1}$ employers who "intentionally, knowingly, or recklessly hire" undocumented immigrants. It was not these stipulations that caught media attention, however. It was the exemption Rep. Riddle wrote into the Bill, which stated that employers hiring undocumented workers were in violation of state law "unless they were hiring a maid, a lawn care worker, or another houseworker." ${ }^{2}$ Many supporters of the bill said the exemption was necessary, especially in Texas, because as Democratic Rep. Aaron Pena told CNN: ${ }^{3}$ "With things as they are today, her bill will see a large segment of the Texas population in prison' if it passes without the exception." ${ }^{4}$ And others saw the exemption as a necessary intervention where the continued hiring of undocumented domestic workers helps sustain the Texas economy.

No matter how the bill was reported or discussed, one thing became glaringly apparent: In Texas there are two kinds of labor and two kinds of employers - public and private. And the private employers and employees (regardless of their immigration status) should not be held to the same rules as those considered public work sites (e.g. construction sites, corporate workplaces, any workplace that is not a home). ${ }^{5}$ The differentiation between sites of labor tells a narrative about Texas' commitment to private interest in lieu of state-wide mandates, practices, or laws. The private citizen and his/her home are central to both the ideologies and economic policies that structure Texas life. And it is because of these 
policies that Texas becomes an excellent site to discuss how aspects of privatization - $\mathrm{a}$ feature central to the economic and political practices of neoliberalism - begin to tell stories about who we "other" and who we exempt in order to define ourselves as discreet communities-Texans, Americans, Homeowners.

It is this need to define ourselves against "others"-Immigrants, Corporate Employers - that allows for neoliberalism to create a culture in which there is the image of a coherent, imagined community, at the same time as the political power and economy of that state is becoming more and more diffuse due to open trade agreements, offshoring of labor and goods, and global monetary exchange. In the example above, immigrants are both defined as outside the nation, but inside the Texas economy. Thus, they become both outsiders and insiders in a sense, but they function rhetorically to allow Texas citizens to define themselves as both distinctly American - those who want to protect their economy and borders from immigrant labor and bodies_-but also distinctly Texan — those who see their private homes as different and above all separate from public and public economy. Therefore, the rhetoric of House Bill 2012 makes particularly visible the complexities and conjunctures of neoliberal culture and economics. The bill is not merely a site where immigrants are "others" in order for nations to deny their economically porous borders. Instead, immigrants are those "Other-others" but they are also "others" who to protect the private economies and comfort of white citizens must be accepted, protected, and brought into the state's borders in order to reify the cultural and economic status quo.

In Strange Encounters, Sara Ahmed talks about the role of the "other" and the "other-other" as two sides of neoliberal nation building in western countries. She talks of how others are the people who those in the nation can "save" or show "benevolence" to by allowing them into the economy and culture of the nation, thus allowing the nation to become multi-cultural. The "other-other" (on the other hand) is the one who cannot be interpellated into culture. It must be expelled, sent away, deported in order for the nation to define and imagine itself, its borders, and its citizenry. According to Ahmed, both "others" and "other-others" are central to determining a national identity-much like an imagined community $^{7}$ once was - in the wake of neoliberal shifts in economic policy and 
political exchange. Now, instead of relying solely on common assumptions of economic frameworks, politically inscribed borders or identities, other bodies — both foreign and domestic — work as key means to define nationhood.

I agree with Ahmed in so much as I see the construction of the "other" and/or the "other-other" working across multiple scales. It is not just a national phenomenon, but it is a neoliberal cultural one wherein the "other" and/or the "other-other" can be employed at multiple scalesthe individual (it's about my maid, my gardener, and my nanny), the local, the national, the international, in order to create a sense of community. But in addition to the mere construction of community, othering also allows for something more insidious. It allows for a masking of the economic and ideological practices which drive neoliberalism at all scales. By creating a range of others as the catalyst for our identity, the material conditions that produce and influence daily lives are occluded. Instead, the focus is placed on the narrative of those others, what they have done, what they may do, and not on the reality of state power and the economic choices that influence us all.

This paper will attempt to disrupt the "othering" of neoliberal rhetoric by looking at two sites in which it was employed-Houston, TX posthurricane Ike and a US national anti-immigration campaign 2004. Both of these sites employ "others" and/or "other-others" to define a community during a time of perceived jeopardy. And both of these sites of othering occlude the material conditions of neoliberal culture, which I argue, produce said jeopardy. By assembling these narratives in such a way, I am striving to create a counter narrative wherein the other can be seen not as a tool of neoliberal culture, but rather a symptom from which we can begin to analyze its material conditions and rhetorical deployments.

\section{No Zoning?!: How Hurricane Ike (De)Mystified De-Regulation}

12 September 2008 Hurricane Ike blew through Houston, TX and the outlying areas. There was not quite as much rainfall as predicted because the hurricane lost momentum upon hitting land and ended up a high category two in ferocity, instead of the predicted category four that had been circling the gulf. However, even at a high category two, Ike managed to 
down trees, rip through roofs, flood neighborhoods, and leave the entire Houston metropolitan area literally powerless.

And it is the reality of and discussions surrounding the month long power-outage that I now want to focus on. And in order to do so, there are a few facts about civic life in Houston that must be made clear. The first is that the city of Houston like the rest of the state of Texas has a strong pro-business governmental orientation. From the lack of city wide zoning (meaning that property can be developed for business or residential anywhere in the city-we won't get into deed restrictions at this point in order to keep this discussion moving) to the lack of personal, business, and state income tax, Houston is invested in business and private property rather than social services or municipal investment.

Seeing that as the political context of Houston and Texas at large, it is not surprising that Houston was an exemplar of Texas' Energy Deregulation which had begun statewide in 2002. And even though there were some critiques of the rising costs of power associated with the privatization of power services, especially in Houston, ${ }^{8}$ during the spring and summer of 2008 the citizens of Houston were in the process of choosing their power delivery companies which were, of course, separate from the power grid company. By the time Ike hit in early September, Houstonians had made their choices and had signed up with particular power companies that they thought would bring the best price-and none of these companies were directly connected to Center Point energy, the company who delivered the power to the delivery companies, who then delivered them to the homes of the millions of residents in Houston.

This move is not rare, and it is merely an example of neoliberal economics wherein prices, ethics, and customer service are guaranteed through competition. Two of the main beliefs in the neoliberal economic model are: the market will regulate itself and competition will insure fair if not low pricing. Sounds good, yes? Well, in the case of post Ike Houston, the good quickly became the ugly when it took over one month to restore power to the whole of the city. During which time, there was seemingly no rhyme or reason as to who got power restored when. No, Houston was no repeat of Katrina in that the wealthy neighborhoods were just as likely to be without power for the duration as those neighborhoods known as the "poor" or lower class ones. The ethnic demographics of the 
neighborhoods had little to do with it. Instead, most citizens of Houston saw the power-out as an inconvenience, but one that was fair ${ }^{9}$ - just like the market.

The local news coverage of the outage, however, did not focus on the parallels between market logic and the city's loss of power. Instead, the power problems were discussed, charted, and reported to be due to the unique nature of Houston's topography and the lack of knowledge and/or ability to understand and overcome the very Houston-ness of Houston. For example, a story that circulated between all three of the local news stations followed out-of-state electrical service workers who had been called in to help restore power to Houston. The reporter would follow them down manholes into sewer like walk ways, up electrical poles as they opened breaker boxes, and around fallen trees as they attempted to clear pathways for trucks and other service vehicles. The conversations between the workers and the news reporters always produced the same three memes: 1) Houston's heat is like nothing they had ever experienced; 2) Houston is full of large bugs which fly at you while you are working; and 3) Houston does not have a clear map of its grid, like other cities, so it is difficult to systematically restore power. Each of these narratives provided a chuckle to the news anchors, and allowed for some levity about how non-Houstonians just don't get Houston.

One could argue that these faux-human interest stories served as a way for uncomfortable and frustrated Houstonians to begin to bond over the trials and tribulations of their collective fate. I, however, see this rhetoric as a function of the neoliberal economics (and the deregulation) responsible for the lengthy return of Houston's power. The use of out-of-state workers as the main conduits of information on the progress of the restoration allows for those gems above to serve as the reasons why power hasn't been returned in a more timely fashion. It is not that the system is flawed, although you could argue that the lack of a map of the grid of Houston does nod to that conclusion. But rather it is the fact that there are "others" who cannot handle what Houston has to offer (the heat, bugs, quirky electrical grid). The use of the "other" 10 is a trend in both media and legislation to shift focus from the failures of power, and place the failures of a system on a group of people who do not belong. I have argued in other work that nationally you see this in 
anti-immigration and anti-LGBT discourses, ${ }^{11}$ but I also argue that here, in a much more benign way, you can see it focused on those workers who came from Montana, Arizona, and California to help restore power here in Houston. They just could not do it fast enough because they aren't part of this unique community.

Jasbir Puar argues that rhetoric is not only used to produce intensities or feelings, but it is used interchangeably to create an assemblage of "othering" that requires totalizing governmental and occasionally coercive means of protection. She draws upon post 9/11 rhetorics of terror demonstrate how "other-others" are mobilized by amalgamating features and histories together so as to create "assembled" threats. Puar defines "the assemblage":

As a series of dispersed but mutually implicated networks, draw together enunciation and dissolution, causality and effect. As opposed to an intersectional model of identity, which presumes components - race, class, gender, sexuality, nation, age, religion - are separable analytics and can thus be disassembled, an assemblage is more attuned to interwoven forces that merge and dissipate time, space, and body against linearity, coherency, and permanency. ${ }^{12}$

Again, in this rhetorical construction history and identity are both palimpsestic $^{13}$ and scrambled, which leads to a critique of the ways in which language represents figures and bodies as discrete and individual. The assemblage works to produce contradictory identities and affective figures that are both mobilized in the name of governmental threat and protection.

According to Manuel DeLanda, ${ }^{14}$ the theory of assemblage joins together the discursive, material, and organic through interactions and reconceptualizations of how we understand our most basic biological and social interactions. We assemble meaning by placing words, phrases, and sentences together (or in my case scenes from the city of Houston) to create meaning, we must also attend to how these words, phrases, and sentences are territorialized and coded or decoded, or as Rebecca Dingo would say networked, ${ }^{15}$ throughout their exchange. And each exchange can be scaled from the minute (discursive assemblages at the sentence 
level, or organic at the atomic level) to the global (assemblages of territorial nation states or biological viruses that grow and adapt other organisms and cells in their wake).

Even within this scene, the assemblage appears in multiple scalesas a rhetorical structure-the development of an "outside worker"; as a spatial organization schema-the focus on "no zoning" and the subsequent seeming lack of city planning; and the economic "free-market"the commitment and implementation of deregulation. The scaling from rhetorical construction, to city planning, to economic policy represents how flexible the assemblage is within rhetorical and critical theory. And they reveal that the assemblage is both discursive and material, as well.

No Zoning and deregulation are both easily translated into Deluezian assemblage theory because after all, per Deleuze, assemblages are just wholes characterized by relations of exteriority. And when a city is deregulated or marked by unrestrained growth, the only way to find meaning is by how the external buildings relate to one another once they are put in place. You cannot look to city plans, corporate schemes, and/ or national ideology. Instead, you are forced to assemble some kind of reading of Houston from the exteriority-how the buildings, the power grid, the people fit together, move around one another. In other words, Houston is a prime city to be read through assemblage theory. Rhetorical Assemblage, however, can be a little more complicated. Therefore, I will give a grounded example of how the figure of the "outsider" of the "other" has been assembled in neoliberal economic and political contexts as a way to define who "belongs" within a particular community, and who must be excluded.

\section{Rhetorical Assemblage, Danger of Othering}

In her 2007 book The Shock Doctrine: The Rise of Disaster Capitalism, Naomi Klein puts forward a productive framework for understanding the collusion between political and economic systems in neoliberal globalization. She discusses how a more appropriate name for what is often called neoconservative or neoliberal economics-practices that "erase the boundaries between Big Government and Big Business"-is "corporatist." ${ }^{16}$ Klein seeks to present to the US public the fallacy that democracy 
and the free-market are one and the same. Klein claims that the key characteristic of the shift to free-market, laissez-faire (what I am calling neoliberal, even though Klein would argue that this is not a sufficient definition $)^{17}$ corporatist economics is that of shock. She cites the theories of Milton Friedman and the students of the Economics department of the University of Chicago as central to this strategy, and she documents how Friedman's belief in "freedom through capitalism" was embraced across the globe from Pinochet's Chile to Thatcher's Britain and Reagan's US According to Klein, Freidman's claim is that if nations took advantage of the state of shock surrounding disasters and catastrophic events, they would more readily pass through legislation to end the Keynesian welfare state once and for all.

Klein's articulation of the consequences of shock is not only descriptive of the economic and political exigency of shock. Instead, she also claims that one of the most important characteristics of shock is the way in which it makes people feel. And it is from that space of feeling that people are persuaded to action. It is not merely rational or persuasive rhetoric that prompts change or apathy in the body politic, but rather it is through a rhetorically and materially produced state of feeling - fear, confusion, anger, disassociation - that the body politic is prompted to seek solace in the government's rhetoric and policies. ${ }^{18}$

Brian Massumi's description of fear reads strikingly similarly to Klein's reading of Friedman. ${ }^{19}$ Instead of focusing on figures and the rhetorical production of shock, he looks at the production of "threats" to show how fear becomes removed from its initial event referent, combined with other memories of fear, and then reassembled to new events with an increased magnitude of fear that is not directly proportional or even applicable to the event at hand. ${ }^{20}$ The reactions and associations created because of this imperceptible joining of discrete events of fear are central to the development and deployment of the rhetoric of neoliberalism. It is the deployment of threat to incite fear that Massumi sees as a critical feature in the rhetoric of neoliberal geopolitics. And because threats are often multifarious, insidious, and non-containable, they become even more threatening when they are amalgamations of combined (if not disassociated) referents. 
Here is an example of the coupling of threats: On December 8, 2006 the Los Angeles, California chapter of Solidarity.org, a pro-immigrant rights group, received a hateful voice mail message. It was from a woman who was later discovered to be from the Arizona chapter of the antiimmigrant group gainusa.org. The woman who identified herself in additional emails to the group as "Laura," attempted to challenge the rhetoric of the immigrant rights movement by reiterating that those who enter the US without appropriate papers are in fact "illegal aliens" and not immigrants of any kind. She states:

You are not immigrants. You are illegal aliens. That is the correct immigration term for sneaks, cheats, and liars. People who sneak into our country; spit on our laws; steal our peoples' identification. That's what you are. You are criminals. Immigrants apply to come to this country. Then they comply with all kinds of requirements like background checks and health checks. And then they get on line and they wait like human beings. Not like crud cheats and liars like illegal aliens. [pause] You will be deported. Stop manipulating our words. Stop trying to manipulate our people. If we go to your country you know that that is a felony. In Mexico it's a felony. And in most other countries it's a felony. Stop trying to take advantage of our laws. Murderers are human beings also, but they're still murderers. Rapists and thieves are still are [sic] human beings, but they are still rapists and thieves. And you people are illegal aliens [hang up]. ${ }^{21}$

There are several things going on in "Laura's" statement. First of all, Laura recognizes the rhetorical moves of the immigrant rights movement to use the term "undocumented immigrants" instead of "illegal aliens." This is an important move in the rhetorical construction of who is crossing the border and how we can begin to think of them. By using the term undocumented instead of illegal and immigrant instead of alien, the immigrant rights movement is attempting to shift the immigration debate from one centered on felonious actions (illegal) by unidentifiable people (aliens) to one of the bureaucratic status (undocumented) of a definable group of people (immigrants). But for "Laura," that rhetorical move is one of 
manipulation and lies. What is evident from Laura's comment and its intended audience is that the immigration debate is one where language and word choice are critical components for both sides of the debate.

But "Laura's" comment also reveals some key assumptions about who immigrates into our country and what they are really doing here. First of all, according to "Laura" these people are "sneaks, cheats, and liars" who "sneak into our country; spit on our laws; and steal our peoples' identification." And much like "murderers, rapists, and thieves" "illegal aliens" may be human beings, but ultimately they are defined as "illegal aliens." By including multiple types of criminals together-thieves, murderers, sexual predators, and illegal immigrants-who do not really have anything to do with one another, Laura is creating an "assemblage of threat"-whose characteristics are then attached to "illegal aliens." Her move to compile different criminal identities, and then associate those characteristics with one particular type of criminal is a move, which I will discuss at length later in this chapter, toward assemblage-wherein the characteristics of figures are removed from the original identities associated with the figures and combined to create an all pervasive or uberthreatening criminal.

Laura's message demonstrates, however crudely, the ways in which assemblage operates by creating associations of threats through mere mention, no matter how faulty the connection between these identities. Part of the work of the assemblage is to demonstrate how the threat in question, in this case the "illegal alien" is not only dangerous because of its own associations, but instead, it is far more dangerous because of its association with other more violent criminals. Therefore, an assemblage is a means with which to heighten the affective intensity surrounding the discussions of threat, and Laura's statement works to do just that. Laura is showing the severity of the threat posed to the US by undocumented immigrants. This echoes her earlier sentiments that "illegal aliens" are "sneaks, cheats, and liars"-all characteristics of successful thieveryand that there are documented cases of the severity of their crime-identity theft of presumably law abiding citizens.

Laura's accusation of thievery, however, is not centered on the notion that "illegal aliens" actually steal anything, although there is an implicit connection to the idea that not "getting on line" is in some way a stealing 
of privilege that is not theirs to take. Instead, their crime is based solely on their immigration status. Laura invokes Mexico's immigration law to support her claim, and discusses how even though HR 4437 may not have passed, "illegal aliens" are felons, and they (the undocumented immigrants) should know this because their presumed home country has the same law. The connection Laura makes to Mexican immigration policy functions to not only show how the US is a more benevolent country than Mexico-presumably because even though immigrants are indeed felons according to Mexican law-but to also show that those entering this country should not expect special treatment because they would not extend the same in their own country.

Additionally, this move to link immigrants to Mexico reveals an assumption that "illegal aliens" come from Mexico. Laura's statement does not only criminalize "illegal aliens" but links them directly with a specific national population. This move racializes the immigration debate, and even though "Laura" never specifically calls "illegal immigrants" Mexicans, her nod to Mexican immigration law prefaced by "if we go to your country" (emphasis mine) makes a clear case that for "Laura" the "illegal immigrant" problem in this country is coming from a specific place (Mexico) and can be attributed to a specific population (Mexicans). For "Laura" not only are undocumented immigrants felons, but they are Mexican, as well. And even when the rhetoric does not specifically link the two, much like "Laura's" rhetoric it creates associations through contiguity - naming legal immigrants in the same paragraph as particular countries, naming illegal immigrants criminals by printing information about thieves and rapists in the same paragraph.

Both media and governmental rhetorical outlets have made immigrant bodies into "other-others" that serve as cautionary tales of what to avoid, who to fear, and who is outside the norm of citizenship. Having been made into "other-others, immigrants are evacuated of any human characteristics and turned into things from which citizens need protection. Laura's rhetoric also demonstrates these "other-others" are assembled-drawing on the traces of previous historical usages. Furthermore, with the eroding of government infrastructures of the Post-Fordist neoliberal world and the development of uber-security forces such as the Immigration and Customs Enforcement Agency (ICE), these 
"other-others" are place together under the same umbrella of surveillance. This material connection allows for an assembling of threats within the cultural imaginary which in turn allows for what I have coined "rhetorical assemblage," wherein the threatening characteristics of one group become applied to another through proximity, not through causality, analogy, or logic.

It is the both/and nature of the assemblage that makes it so dangerous. It draws on seemingly commonplace historical associations (i.e. Mexican immigrant), and then brings several of those together to create new associations that are not created through metaphor or analogy, but rather are created through contiguity. It is through the rhetorical means of placing brands next to one another in a chapter or a sentence without creating direct analogy or presenting the connections in any clear way that defines the assemblage in our "neoliberal kairotic moment." 22

Within this moment, clearly identifiable threats are no longer the norm. Instead, the rhetoric surrounding protection and threat works to create an ever present, unidentifiable, yet strangely familiar, series of threats. And the discussion of these threats uses affective intensity and identification to help citizens recognize just how much they need protection. The shift toward assemblage-creating multivalanced threat through contiguity, much like Laura, creates a different type of political rhetoric - what I am calling the rhetoric of terror. These threats create new circumstances for law enforcement which impacts citizens and noncitizens alike.

\section{Houston, TX: An Exemplar Neoliberal City}

The establishment of the "other" can be seen functioning in the media around issues of national crisis: presidential elections, economic downturns, and in the case of Houston (although there was coverage of the devastation in Galveston, TX) — a "powerless" city. The stakes of a power out versus an economic collapse are obviously less, and therefore, the story did not carry. However, the presence of "others" still served a distinct purpose for the Houston area. In fact, there was little national coverage of post-Ike Houston largely because the Monday after the storm, Wall Street collapsed sending the entire country into an economic tailspin. 
Therefore, there was no need to follow a regional story about a city that appeared to be purely victimized by the weather, even if the local press saw it otherwise.

Even though the discussions of out-of-state workers do not carry the potential stereotypes and material harm we find in the othering of LGBT and immigrant bodies, I see this discussion of other-ness as indicative or symptomatic of neoliberal discourse. The naming of outsiders as a cause for the delay in power restoration to Houston masks several very real reasons that caused the power to remain out in many parts of Houston for over one month. The first is the presence of deregulation in Houston. The power companies who delivered electricity to residences and business were only responsible for the delivery of that power-not the infrastructure that supplied the power. In other words, due to deregulation and the separation of power companies into multiple private entities, power in Houston comes into a home or office via one company, but is supplied to that company's wires which start close to said building by Center Point energy. Now Center Point does not deliver power, but it does manage the infrastructure that supplies power from the plants into the city, suburbs, and even unincorporated areas of Houston. So, if your home is without power, it could be the delivery service (which could be one of 20 plus companies) or it could be Center Point that is to blame. However, you will not know who to contact because your neighbor may have power, but that has to do with their personal choices of their power delivery and/or what portion of Center Point's grid they are on. And yes, the grid is a mess largely because of the lack of zoning laws in Houston along with its unrestrained growth. The power infrastructure is a huge maze and no single company holds the map.

Let me break for a moment here to state clearly that Houston lost power because of hurricane Ike, but it remained without power for over one month because of deregulation and its commitment to neoliberal economics. And the power out was seemingly ruled by nothing more than the market—not some ideological, racist, or classist beliefs about whose power should be restored first. Now, by no means is that entirely true. Houston is an incredibly segregated city, but it is all done through defacto-segregation (schools are almost exclusively African-American, or Caucasian, or South East Asian not because they are segregated, but 
because Houston does not want to pay for bussing, and therefore, according to the Houston Independent School District-schools districting is done through economics not census) ${ }^{23}$. However, many believe that this adherence to economics in all of its decisions is a way for Houston to remain racially neutral in its politics. Even liberals to whom I presented my reading of the post-Ike power-out always felt a little proud when confronted with the fact that post-Ike was not post-Katrina because the issues in Houston did not only effect lower class African American neighborhoods, but they effected everyone in Houston-equally or seemingly rationally.

In The Feeling of Kinship: Queer Liberalism and the Racialization of Intimacy, David Eng discusses the logic of colorblindness. He states that:

[A] politics of colorblindness willfully refuses to acknowledge the increasing socio-economic disparities that mark our society, while also refusing to see these disparities as anything other than the just distribution of inequality to those who are unwilling to participate in the so called level playing field of the neoliberal market. ${ }^{24}$

If we follow this logic through, those in Houston who live in "depressed socio-economic" areas are not participating fully in the neoliberal economic system of the city. It is choice, laziness, or individual circumstance that prevents them from reaching a better economic station. In other words, for Eng, colorblindness is another version of the myth of meritocracy - the belief that anyone can work hard enough and have the same opportunities as anyone else. And if someone is disadvantaged it is because of their own faults or missed attempts at improvement.

These beliefs support and mobilize the rhetoric of equality, and that rhetoric continues to allow us to construct "others" who are exceptions - people who may need a little help to become citizens, gain better economic footing, but ultimately will face a "choice." The either become a part of the neoliberal economic system of the city, or "other-others" those who will never participate fully in the neoliberal economy, and thus must be expelled from the state. "Othering" and equality work in tandem to produce a rhetoric that masks the material effects of any given choice or crisis, so much so, that said effects appear to be equal across the board. 


\section{Jennifer Wingard}

Now, I am not arguing that Houston is the only place where this can happen. Jenny Edbauer in her work on rhetorical ecologies shows how the local rhetoric in Austin-a much smaller and more liberal Texas town-circulates by "moving across the same social field and within shared structures of feeling." 25 Edbauer draws on Raymond Williams' notion of "structures of feeling,"26 a term Williams defines as "difficult" but "concerned with meanings and values as they are actively lived and felt, and the relations between these and formal or systemic beliefs are in practice variable (including historically variable), over a range from formal assent with private dissent to the more nuanced interaction between selected and interpreted beliefs and acted and justified experiences. An alternative definition would be structures of experience." ${ }^{27}$

The presence of the "other" and "other-other," as well as the invocation of equality, work to create a public experience all the while maintaining the private nature of experience. This seemingly contradictory move to make experience both public and private mirrors even the most basic spatial conditions of neoliberalism - the mall, the freeway, and the promenade are all public private spaces. The rhetorical moves within Williams' structures of feeling are quite in line with the economic and political beliefs of neoliberalism. Therefore, neoliberalism can name anything as a value or meaning, "freedom" or "equality" for example, as long as it fits with current beliefs. So the "others" who helped to restore power were not "bad" because they didn't know Houston. Instead, their lack of knowledge became a way for Houstonians to share a momentary feeling of pride in their uniqueness - which by extension makes the month long power-outage part of our uniqueness, as well. After all, it was the most equanimous hurricane and post-power-outage the world had seen.

\section{Works Cited}

Agamben, Giorgio. Homo Sacer: Sovereign Power and Bare Life. Palo Alto, CA:

Stanford UP, 1998.

Ahmed, Sara. Strange Encounters: Embodied Others in Post-Coloniality. New York:

Routledge, 2000.

Alexander, M. Jacqui. Pedagogies of Crossing: Meditation of Feminisms, Sexual Politics, Memory, and The Sacred. Durham, NC: Duke UP, 2005. 
Anderson, Benedict. Imagined Communities: Reflection on the Origin and Spread of Nationalism. London: Verso, 1983.

Castillo, Mariano. “Texas Immigration Bill has Big Exception.” CNN.com (1 March 2011). http://articles.cnn.com/2011-03-01/politics/texas.immigration. bill_1_immigration-bill-unauthorized-immigrants-issue-of-illegal-immigration? $s=\overline{P M}:$ POLITICS

DeLanda, Manuel. New Philosophy of Society: Assemblage Theory and Social Complexity. New York: Continuum, 2006.

Dingo, Rebecca. Networking Arguments: Rhetoric, Transnational Feminism, and Public Policy Writing. Pittsburgh, PA: University of Pittsburgh Press, forthcoming.

Edbauer, Jenny. "Unframing Models of Public Distribution: From Rhetorical Situation to Rhetorical Ecologies.” Rhetoric Society Quarterly 35.4 (Fall 2005): 5-24.

Eng, David. The Feeling of Kinship: Queer Liberalism and the Racialization of Intimacy. Raleigh, NC: Duke UP, 2010.

Fowler, Tom and Janet Elliott. "Many call energy deregulation in Texas a failure." Houston Chronicle (6 October 2007). http://www.chron.com/business/article/ Many-call-energy-deregulation-in-Texas-a-failure-1824046.php

Hin, Lee Siu. “12/8: Very Serious Hate-E-Mail/Call/Threat Against Immigrant Solidarity Network." Immigrant Solidarity Group. immigrantsolidarity. org. December 8, 2006. http://www.immigrantsolidarity.org/Campaigns/ Minutemen2006.htm

Klein, Naomi. The Shock Doctrine: The Rise of Disaster Capitalism. New York: Picador, 2008.

Massumi, Brian. “Fear (The Spectrum Said).” Positions 13.1 (2005): 31-48.

Mies, Maria. Patriarchy and Accumulation on a World Scale. New York: Zed, 1986.

Puar, Jasbir K. “Queer Times, Queer Assemblages.” Social Text 23.3-4, 84-85 (November 2005): 121-139.

-. Terrorist Assemblages: Homonationalism in Queer Times. Durham, NC: Duke UP, 2007.

-. and Amit Rai. "Monster, Terrorist, Fag: The War on Terrorism and the Production of Docile Patriots.” Social Text 72, 20.3 (Fall 2002): 117-148.

Scott, J. Blake. "Kairos as Indeterminate Risk Management: The Pharmaceutical Industry's Response to Bioterrorism.” Quarterly Journal of Speech 92 (2006): 115-143. 
Williams, Raymond. Marxism and Literature. Oxford: Oxford University Press, 1977.

Wingard, Jennifer. Branding Bodies: Rhetorically Assembling the Nation State. Boston: Lexington Press, forthcoming.

\section{Notes}

1. The penalties proposed are up to a $\$ 10,000$ fine and/or 2 years in state prison.

2. Mariano Castillo, “Texas Immigration Bill has Big Exception,” CNN. com (1 March 2011). http://articles.cnn.com/2011-03-01/politics/texas. immigration.bill_1_immigration-bill-unauthorized-immigrants-issue-ofillegal-immigration?_s=PM:POLITICS

3. Ibid.

4. The appearance of the terms "exemption" and "exception" are both notable. Giorgio Agamben, Homo Sacer: Sovereign Power and Bare Life (Palo Alto, CA: Stanford University Press, 1998) and Jasbir Puar and Amit Rai, "Monster, Terrorist, Fag: The War on Terrorism and the Production of Docile Patriots," Social Text 72, 20.3 (Fall 2002): 117-148, both discuss current forms of state sovereignty based in the development of exceptions-who is recognized as a citizen, who must be expelled or imprisoned. Within this short news story, it appears the Representatives within the state of Texas see threats to the economy and citizenry of Texas defined by exception, as well.

5. This division of labor is also quite gendered. It is defining the reproductive labor of the home which has been scripted and defined as "feminine labor" (Maria Mies, Patriarchy and Accumulation on a World Scale [New York: Zed, 1986]) as outside the dominant public economy of the state. Although there is a recognition that the monetary exchange provided to this labor is within the realm of the state economy, the bodies that perform the labor, the domestic workers, are not seen coded as threat, like their productive economy counter parts-factory and/or corporate workers.

6. Sara Ahmed, Strange Encounters: Embodied Others in Post-Coloniality (New York: Routledge, 2000), defines other-others as those who cannot be interpellated into society, therefore, they must be expelled.

7. Benedict Anderson, Imagined Communities: Reflection on the Origin and Spread of Nationalism (London: Verso, 1983), wrote that citizens imagined commonalities of nations through symbolism, hegemony, and constructed memories. In other words, the culture of nations are not inherently stable or produced through shared experience.

8. Tom Fowler and Janet Elliott, "Many call energy deregulation in Texas a failure," Houston Chronicle (6 October 2007). http://www.chron. 
com/business/article/Many-call-energy-deregulation-in-Texas-afailure-1824046.php

9. Or perhaps even "cruel but fair."

10. Ahmed's intelligible foreign body-and these out-of-state workers certainly fit that definition. They are different enough to help a community define itself, but not so different as to need to be expelled.

11. Jennifer Wingard, Branding Bodies: Rhetorically Assembling the Nation State (Boston: Lexington Press, forthcoming).

12. Jasbir K. Puar, “Queer Times, Queer Assemblages,” Social Text 23.3-4, 84-85 (November 2005): 121-139, p. 127-128. Jasbir K. Puar, “Terrorist Assemblages: Homonationalism in Queer Times (Durham, NC: Duke University Press, 2007).

13. A palimpsestic reading, according to M. Jacqui Alexander (Pedagogies of Crossing: Meditation of Feminisms, Sexual Politics, Memory, and The Sacred [Durham, NC: Duke University Press, 2005]), who works to define ideology as inflected and mobile in her book Pedagogies of Crossing, allows scholars to begin to view ideological practice as unbounded by history and nation. It is a shift necessary for understanding ideology as transnational in its very conception. Alexander defines the transnational not only spatially but also temporally. She asserts that our current state ideologies are not developments from historical moments, but rather they are carried throughout time shifting and mutating (but not becoming wholly different) in particular circumstances. She uses the term "ideological traffic" to reveal the ways in which the same ideologies can be seen functioning in historical spaces, as well as current ones.

14. Manuel DeLanda, New Philosophy of Society: Assemblage Theory and Social Complexity (New York: Continuum, 2006).

15. Rebecca Dingo, Networking Arguments: Rhetoric, Transnational Feminism, and Public Policy Writing (Pittsburgh, PA: University of Pittsburgh Press, forthcoming). In her forthcoming book, Dingo discusses how rhetoric is formed through neoliberal linkages that cross both global and economic borders. She examines policy and NGO public exchanges to demonstrate how neoliberal culture has created conditions for changes in rhetorical practice.

16. Naomi Klein, The Shock Doctrine: The Rise of Disaster Capitalism (New York: Picador, 2008), p. 15.

17. Naomi Klein, The Shock Doctrine. Klein argues that the term neoliberal economics is too vague and does not specify who benefits from and whose interests are served by our current governmental economic protocols. She believes that corporatist economics is more descriptive of the true nature of the economic system in place today. I, however, decline to take on Klein's terminology because I feel that corporatist economics only grants definition 
to the power base that benefits from the economic system and can easily occlude those who are positioned to serve as material labor for the corporate system. What becomes interesting is the ways in which contiguous reasoning, which I am examining as particular to the assemblage in this chapter, function not only in association with identities and individual threat. Think of the Bush administration's reasoning for invading Iraq. It was not based in logic or the demonstration of fact, but rather it was the repetition of the meme that Saddam Huessin was involved with Al-Qaeda. And even now when this has been proven inaccurate, there are some who still hold on to this tenuous connection to justify our presence in Iraq.

18. The greatest irony here is that during times of "shock" the public returns to the social contract in the hopes that their civil liberties will be protected and honored by their government. Yet it is that very moment that the government is using the public's desire for protection to erode those civil liberties and the social contract upon which they have come to rely. A strong example of this exchange is post-9/11 America and the development of the Patriot Act. The legislation was "sold" to the American public as necessary to protect them. All the while it stripped them of many basic civil liberties in the name of that protection.

19. Brian Massumi, “Fear (The Spectrum Said)," Positions 13.1 (2005): 31-48.

20. This is how the justification for the invasion of Iraq 2003 was created.

21. Lee Siu Hin, "12/8: Very Serious Hate-E-Mail/Call/Threat Against Immigrant Solidarity Network,” Immigrant Solidarity Group, immigrantsolidarity.org, December 8 2006. http://www.immigrantsolidarity. org/Campaigns/Minutemen2006.htm

22. J. Blake Scott, "Kairos as Indeterminate Risk Management: The Pharmaceutical Industry's Response to Bioterrorism," Quarterly Journal of Speech 92 (2006): 115-143. Scott's notion of "neoliberal kairotic exigency" is one of movement, circulation, and affect in which a rhetor (or rhetorical scholar for that matter) cannot classify and/or know all the conditions of rhetorical practice, and therefore, cannot fully control the rhetoric.

23. Defacto and dejure segregation are, however, forms of racial segregationthey merely rely on economics or political districting as the structuring force instead of ideology. What they do not allow for (or admit to) is that most economically disadvantaged neighborhoods have deep ties to racially structured political pasts, such as segregation and immigration statutes. Therefore, even the most seemingly "fair" economic plan contains remnants of racial ideology.

24. David Eng, The Feeling of Kinship: Queer Liberalism and the Racialization of Intimacy (Raleigh, NC: Duke University Press, 2010), p. 5. 
25. Jenny Edbauer, "Unframing Models of Public Distribution: From Rhetorical Situation to Rhetorical Ecologies," Rhetoric Society Quarterly 35.4 (Fall 2005): 5-24, p. 20.

26. Raymond Williams, Marxism and Literature (Oxford: Oxford University Press, 1977).

27. Ibid., p. 132 (emphasis in original). 
Chapter 5

\title{
Neoliberalism, Autoimmunity and Democracy Derrida and the Neoliberal Ethos
}

\author{
ZAHI ZALLOUA
}

In the American neoliberal imaginary, democracy and the free market are symbiotically interwoven; the latter could not exist without the full presence of the former in the realm of public discourse. In addition to guaranteeing a way of life at home, neoliberalism serves in this imaginary as a global antidote to the most corrupt and tyrannical governments in the world. Winning the "hearts and minds" of would-be terrorists goes hand and hand with the promotion of neoliberal ideals. In 2003, for example, Paul Bremer, then head of the Iraqi Coalition Provisional Authority, observed that "rebuilding the Iraqi economy based on free market principles is central to our efforts." The neoliberal ethos, however, does not merely dominate the public or political sphere; it also structures our very mode of being. ${ }^{2}$ Two decades ago, Fredric Jameson alerted us to the dangerous and alarming ways neoliberal rhetoric infiltrates not only how we conceptualize the economic field but also how we understand our place within that field: “'The market is in human nature' is the proposition that cannot be allowed to stand unchallenged; in my opinion, it is the most crucial terrain of ideological struggle in our time." ${ }^{3}$ Neoliberal ideology has thoroughly naturalized itself-appearing to its defenders and dissenters alike as the only game in town. As the argument goes, global capitalism may not be perfect-but what else is really out there as an alternative?

More recently, Slavoj Žižek reiterated Jameson's sense of urgency mixed with utter dismay at the cognitive state of the public at large, 
noting how 'it seems easier to imagine the 'end of the world' than a far more modest change in the mode of production." ${ }^{4}$ For Žižek, one symptom of capitalism's triumphant reign is the alleged "return to ethics" that made its way into Western universities, particularly in the humanities. On Žižek's account, with the return to ethics, the Left's project of radical democracy has fallen victim to a pervasive type of intellectual blackmail:

$[\mathrm{T}]$ he moment one shows a minimal sign of engaging in political projects that aim to seriously challenge the existing order, the answer is immediately: "Benevolent as it is, this will necessarily end in a new Gulag!” The 'return to ethics' in today's political philosophy shamefully exploits the horrors of the Gulag or Holocaust as the ultimate bogey for blackmailing us into renouncing all serious radical engagement. ${ }^{5}$

For the humanist liberal, revolt, not revolution, is the reasonable and moral way of proceeding, a position to which Žižek is entirely opposed.

It is not a secret that Žižek blames postmodernism-Derrida is a favorite target-for fostering an intellectual climate wholly compatible with neoliberalism. Derridean skepticism hardly suffices to dismantle capitalism's "general matrix," its ideological system of thought production and regulation. Yet what most offends Žižek is not Derrida's philosophy as such, but its academic reputation as subversive. In this essay, I want to challenge Žižek's reading of Derrida, and to show how Derrida offers a powerful critique of the neoliberal ethos, in particular in his reflections on the autoimmunity of democracy.

Derrida first evoked the biomedical term of autoimmunity in his 1996 article "Faith and Knowledge." This essay focused, in part, on religion's paradoxical relation to technology: how religion - in its desire to remain pure, sacred-defines itself in opposition to technology while, also, needing technology to survive and spread in a global world. But it was in the aftermath of $9 / 11$ that autoimmunity gained far more prominence in Derrida's conceptual analysis. Derrida's reflections on autoimmunity open up a space for rethinking democracy and sovereignty in ways that challenge the cultural work of neoliberalism, seen most visibly in its interpellation $^{7}$ of a given individual as a private, competitive, self-interested, 
calculating, de-politicized —or post-ideological—economic subject, that is, homo economicus. ${ }^{8}$

Derrida's critique of neoliberalism is both ethical and political in nature; yet, there is in Derrida a tension, a friction between these two incommensurable registers. He retains at some level Levinas' view of ethics as involving a dyadic relation while politics involves the Third, the other's others, so to speak. Yet Derrida never seeks to affirm ethics as first philosophy; rather, ethics and politics constantly supplement one another, contaminating one another. In speaking of the ethics of autoimmunity, we must also speak of the autoimmunity of ethics, in an effort to account for this slippage of the ethical when talking about democracy as a political category.

To begin, what is autoimmunity and how does it affect the individual body as well as the political body? In biomedicine autoimmunity signifies a disorder, a living organism's failure to recognize that it is attacking a very part of itself - and not just any part, but the immune system, the system that protects the living being from foreign, harmful elements. In the process of autoimmunization, Derrida writes, "a living being, in a quasisuicidal fashion, 'itself' works to destroy its own protection, to immunise itself against its 'own' immunity."

Moving from the individual body to the political body, Derrida examines "this strange illogical logic" of autoimmunity, as he calls it, in America's response to the traumatic events of $9 / 11$. In its desire to protect itself, to immunize itself against the spreading disease of terrorism, America illustrated all-too-well the potential "pervertibility of democracy,"10 "los[ing] itself by itself," self-protection, against, that is, its immune system: laws aimed at safeguarding the legal rights of its subjects, especially during states of emergency. In its fight against the virus of terrorism, American democracy, under the willful watch of "homeland security," thus suppresses its own traditional mechanisms of auto-protection - and arguably compromises its own integrity, its moral core, its ethical ideals - in favor of an alternative, hyper-vigilant mode of self-protection that must posit America in a state of perpetual war. Former Deputy Assistant Attorney General John Yoo made explicit, in Machiavellian fashion, this ideological shift in what constitutes military normalcy after 9/11: "The world after September 11, 
$2001 \ldots$ is very different from the world of 1993. It is no longer clear that the United States must seek to reduce the amount of warfare, and it certainly is no longer clear that the constitutional system ought to be fixed so as to make it difficult to use force. It is no longer clear that the default state for American national security is peace." ${ }^{12}$

In the same spirit, we could say that it is also no longer clear that the default state for the legal American system is due process. To be sure, the US Constitution makes provision for suspension of the Writ of Habeas Corpus, but this option is reserved for truly exceptional situations: only in cases of rebellion or invasion can the Writ of Habeas Corpus actually be suspended. ${ }^{13}$ The putative necessity of an open-ended "war on terror" supersedes this fundamental legal protection, transforming an exceptional and temporary action into a far more normal and permanent condition. The "Patriot Act," more generally, emblematizes this curtailing of individual civil liberties in the name of a greater/est good: American sovereignty.

But how does American sovereignty-its power to decide the state of exception, to determine to whom the law applies and to whom it does not-fit within the economic space of the neoliberal global order? Quite smoothly! As Wendy Brown observes, though "neoliberal rationality" did not cause current American practices, it "has facilitated the dismantling of democracy during the current national security crisis. Democratic values and institutions are trumped by a cost-benefit and efficiency rationale for practices ranging from government secrecy, even government lying, to the curtailment of civil liberties." ${ }^{14}$ Neoliberal rationality thus, at the very least, contributes to America's ethical disorder, to America's autoimmune disorder, by making its democratic institutions all the weaker, all the more vulnerable to political and legal abuse.

In her chapter "Sovereign Hesitations," which appears in the 2009 edited volume Derrida and the Time of the Political, alongside an essay by Jacques Rancière to which I will turn shortly, Brown pursues a more direct engagement with Derrida on these matters. To be sure, ever since his 1993 Specters of Marx, ${ }^{15}$ Derrida has increasingly caught the interest of critics from the Left. Like many, Derrida sought to disrupt the particular conservative intellectual climate under which neoliberalism flourished in 
an almost uncontested way, soundly rejecting such claims as Fukuyama's pronouncement that the "end of history" had arrived:

For it must be cried out, at a time when some have the audacity to neo-evangelize in the name of the ideal of liberal democracy that has finally realized itself as the ideal of human history: never have violence, inequality, exclusion, famine, and thus economic oppression affected as many human beings in the history of the earth and of humanity. ${ }^{16}$

Derrida's intervention attempts to elicit skepticism, doubt about this neoliberal grand narrative. Despite (or because of) his explicit encounter with Marx and Marxism, the Left (I use the word to refer to a wide range of progressive thinkers who may not necessarily agree with one another) has continued to keep its distance, scrutinizing what Derrida may offer in terms of an effective critique of neoliberal hegemony.

Brown is a case in point. In "Sovereign Hesitations," she explores the vexed relation between sovereignty and democracy in Derrida's 2003 work Rogues (Voyous). Whereas Brown emphatically argues for a "participation in power that is greater than oneself," 17 Derrida, she finds, presents a mostly negative and excessively skeptical attitude toward the demos. For instance, in Rogues, Derrida writes:

[Sovereignty is] the concentration, into a single point of indivisible singularity (God, the monarch, the people, the state or the nation-state), of absolute force and the absolute exception. ${ }^{18}$

Derrida's conflation of democracy with force (kratos) excludes what Brown considers essential for political critique and a critique of the political, namely a commitment to "shared power," to the ideal of "governance in common." ${ }^{19}$ For Brown, Derrida reverts back to a rather traditional model of the liberal individual — the subject who is defined by his or her freedom-identifying democracy with "individual liberty." ${ }^{20}$ Indeed, it would not be an overstatement to say that Derrida is allergic to the idea of the common, to the idea of belonging to some phantasmatic "we":

"I am not one of the family" means do not consider me "one of you”, "don't count me in”, I want to keep my freedom, always: 
this, for me, is the condition not only for being singular and other, but also for entering into relation with the singularity and alterity of others. ${ }^{21}$

Yet, the picture might be more complicated than it first appears: what Derrida is objecting to here is not a sense or even the possibility of a collectivity but its affirmation as a point of departure. Why? Behind such an affirmation often lies a logic of exclusion (of fraternity, of the family, of the Nation-state, etc.), a logic so ingrained in thought that an ethical relation to the other worthy of its name would be all but ruled out.

I would like to follow Brown and see Derrida as hesitating here, but hesitating in a way that exceeds its rather limiting meaning in Brown's suggestive title "Sovereign Hesitations." In fact, hesitation as such drops out of the essay completely. It is only intended to convey Derrida's ambivalence about his deconstruction of sovereignty; Derrida truly wants to overcome its dubious metaphysics but he ultimately views the individual as a baby that he hesitates to throw out with the bathwater, the ontotheological legacy of sovereignty. But isn't there an alternative reading of hesitation, one that is more "faithful" to Derrida's own use of the term?

Readers of Derrida will recognize that in his work, hesitation does not at all represent a failure of action; rather, it is a kind of failure that shortcircuits the very logic of success. Hesitation is a hermeneutic principle that Derrida adopts earlier in his writings. In his 1967 essay "Violence and Metaphysics," for example, Derrida foregrounds hesitation in his critical reading of Levinas' ethics of difference, disputing Levinas' "dream of a purely heterological thought."22 Yet Derrida does not dismiss Levinas' radical project. Quite the contrary: while carefully exposing Levinas' dependence on a philosophical discourse that he claims to have left behind, Derrida nevertheless argues that the question is not one of choosing between infinity and sameness, between "the opening and the totality"2: "Without reflecting here upon the philosophy of this hesitation, let us note between parentheses that by simply articulating it we have already come close to Levinas' own problematic." ${ }^{24}$ Refusing an either/or logic, Derrida opts to hesitate between infinity and sameness. Though there is always something surprising about the other, something "wholly other," a pure or unmediated encounter with the other remains 
something of a phantasm. And to be sure, we find Derrida, at times, alltoo-enthralled by this phantasm of a "pure ethics":

Pure ethics, if there is any, begins with the respectable dignity of the other as absolute unlike, recognized as nonrecognizable, indeed as unrecognizable, beyond all knowledge, all cognition and all recognition: far from being the beginning of pure ethics, the neighbor as like or as resembling, as looking like, spells the end or the ruin of such an ethics, if there is any. ${ }^{25}$

In his article "Ethics and Politics in Derrida," Jacques Rancière likewise laments Derrida's proximity to Levinas:

That affirmation of a radical heteronomy is what some of our contemporaries make the touchstone of ethics: ethics would properly mean the law of the heteron, a heteron that was constructed at the crossroads of the Levinasian Other and the Lacanian Thing. That conception of ethics substitutes the unconditional law of heteronomy for the Kantian unconditional law of self-determination of the subject. ${ }^{26}$

Derrida's turn to Levinas is read here as an ideological return to ethics, a reframing of "political matters in ethical terms." ${ }^{27}$ For Rancière this transfiguration of political concerns into ethical ones is not simply conceptual cosmetics. Simply stated, Derrida errs in privileging ethics (irreducibility and dissymmetry) over politics (equality and symmetry). Derrida's democracy is "a democracy without demos," ${ }^{28}$ which is, for Rancière, utterly detrimental to the task of politics.

Yet Rancière does not pay sufficient attention to Derrida's selfpuncturing moments of doubt, to moments such as the one above, where Derrida entertains thoughts of a pure ethics while qualifying such remarks with the repetition of the words, "if there is any," drawing attention, as it were, to the phantasmatic character of a "pure ethics." Moreover, Rancière draws too static of an opposition between ethics and politics, locating "justice" in the sphere of the calculable, in the realm of politics. And though he quotes Derrida as saying that "incalculable justice urges us to calculate" before paraphrasing Derrida's view of politics as "an unrelenting negotiation between calculation and the incalculable, the possible and the impossible, autonomy and heteronomy," ${ }^{30}$ Rancière 
believes that the theoretical damage has been done: the political has been irredeemably severed from the ethical.

Like Brown, Rancière is unwilling to entertain a politics, a notion of justice that is not firmly grounded in the equality of the demos. As Rancière repeatedly insists, "the equivalence of the same and the other" 31 is a precondition for emancipatory politics. The Derridean aporeticand the type of hesitation that it solicits-is simply foreign to politics. From the perspectives of Brown and Rancière, Derrida ought, then, to be treated with some suspicion on the grounds that he remains too ideologically invested in the subject (at the expense of the collective) and for endorsing what amounts to a de-politicized philosophy of the other. I would like next to question both of these objections, and suggest how an aporetic or autoimmune understanding of democracy might provide the Left with a different conceptual model with which to contest neoliberalism's cultural work.

Here Žižek's notion of the parallax view might help us add a fresh perspective on Derrida's notion of "democracy to come" and his logic of autoimmunity. Žižek himself makes a similar gesture of rapprochement in his 2006 book The Parallax View; he limits it, however, to the early Derrida's use of différance-to Derrida's later notions, like "democracy to come," he remains quite hostile. ${ }^{32}$ If the OED defines parallax as the "difference or change in the apparent position or direction of an object as seen from two different points," for Žižek, the parallax signifies far more. Žižek harnesses its conceptual potential, using it to reconceptualize the interpretive scene itself. As Žižek puts it, “The philosophical twist to be added [to the standard definition of parallax] ... is that the observed difference is not simply 'subjective, due to the fact that the same object which exists 'out there' is seen from two different stances, or points of view. It is rather that ... subject and object are inherently 'mediated,' so that an epistemological' shift in the subject's point of view always reflects an 'ontological' shift in the object itself." ${ }^{33}$ Reading Lacan with Hegel, and Hegel with Lacan, Žižek conceives of the dialectic as an on-going process involving a constant shift in perspective between two points "between which no synthesis or mediation is possible" ${ }^{34}$ : indeed, the parallax gap reveals that "there is no common language, no shared ground" 35 on or through which 
such a synthesis or mediation could take place. With this in mind, isn't Derrida adopting a kind of parallax view in the following passage?

$[\mathrm{T}]$ here is the impossible, whose promise democracy inscribes - a promise that risks and must always risk being perverted into a threat. There is the impossible, and the impossible remains impossible because of the aporia of the demos: The demos is at once the incalculable singularity of anyone, before any "subject" ... beyond all citizenship, beyond every "state," indeed every "people," indeed even beyond the current state of the definition of a living being as living "human" being, and the universality of rational calculation, of the equality of citizens before the law, the social bond of being together, with or without contract, and so on. ${ }^{36}$

Derrida offers what can be described as a parallactic approach to the demos; the aporia of the demos ("the enigma or the autoimmune double bind of the democratic" $[2005,38])$ that "democracy to come" articulates and sustains can only be grasped parallactically. The moment of aporia results from democracy's incommensurable injunctions: to respect the absolute singularity of each being and to value each of its members equally: to be "indifferent to difference," as Rancière would put it. The movement between these two injunctions (both not to compromise and to compromise on the alterity of the other) is shot through with hesitation. The double bind of the demos (to uphold the phantasm of the pure other and to remove all distinctions among its citizens) can thus be reread dialectically in terms of the parallax view ${ }^{37}$ : these two perspectives on the demos share no common language. The "Real" of the demos, so to speak, resides in this parallax gap. And like Žižek, Derrida seeks to conceive of this gap in its temporality or "becoming." 38

For Derrida, "democracy to come" indeed entails a permanent condition of (self)critique; he reinterprets the eighteenth-century notion of democracy's perfectibility as a call for "interminable analysis." "Democracy to come" is thus clearly not governed by a "regulative idea"; it is, as Derrida says, "foreign to the order of my possibilities." ${ }^{40} \mathrm{He}$ goes on to add: 
When there is a determinable rule, I know what must be done, and as soon as such knowledge dictates the law, action follows knowledge as a calculable consequence: one knows what path to take, one no longer hesitates, the decision then no longer decides anything but simply gets deployed with the automatism attributed to machines. ${ }^{41}$

How to interpret the other in a non-mechanical manner-in stark opposition to the fantasy of the neoliberal calculating machine-preoccupied Derrida throughout his career. Derrida illustrates and enacts this mode of hesitation through his formulation of the rapport sans rapport ("relation without relation"). This paradoxical relation entails both a relation and a non-relation to the other; it joins and disjoins. This relationless relation sustains "a non-appropriative relation to the other" ${ }^{42}$; it answers the aporetic demands made upon me by the other: to be understood without being reduced to an object of comprehension, to never dissolve the "without" of the "relation without relation" that interrupts any traditional, static subject-object relation and respects the alterity of the other. The rapport sans rapport necessitates, in this respect, a parallactic mode of thought.

In many ways the illogic logic of autoimmunity translates Derrida's earlier notion of a rapport sans rapport. As with any translation, however, the "original" always undergoes a transformation of some kind. While the notion of the rapport sans rapport focuses on the other's irreducibility to me, and, though, in principle, the same could be said of my own irreducibility to the other's interpretive gaze, simply pointing out that the relationship is reversible, and thus making to some extent an abstraction of the existing relation, always runs the risk of harmonizing the two temporalities, of reintroducing a compromising symmetry at the heart of the ethical relation. Autoimmunity reorients the ethical inquiry back to the self without, at the same, reducing the other to the economy of the same. Both Brown and Rancière fail precisely to acknowledge this strategic function of the return to the individual - neither of them, in fact, discusses the notion of autoimmunity in their critical reading of Derrida.

Autoimmunity not only reveals the dangers of a political body's inability after 9/11 to discern its own cells (or citizens) from pathogens (or terrorists), but unravels what he dubs the "phantasmatico-theological" 43 
character of sovereignty: "it is not some particular thing that is affected in autoimmunity but the self, the ipse, the autos that finds itself infected." ${ }^{4}$ Autoimmunity produces hybrid sovereigns, or what he calls "sovereign[s] without sovereignty." ${ }^{45}$ Making an analogy with a body's need for immuno-depressants (functioning as a necessary "supplement" to the immune system) to counter its natural antibodies and render possible "the tolerance of certain organ transplants," ${ }^{26}$ Derrida stresses the self's finitude and lack of self-sufficiency. ${ }^{47}$ But what follows from this heteronomous condition is neither despair nor nostalgia but an awareness of the relational quality of the self, an ethical awareness of the self's exposure to otherness: "[A]utoimmunity is not an absolute ill or evil. It enables an exposure to the other, to what and to who comes-which means that it must remain incalculable. Without autoimmunity, with absolute immunity, nothing would ever happen or arrive; we would no longer wait, await, or expect, no longer expect one another, or expect any event." ${ }^{4}$ Elizabeth Rottenberg aptly describes autoimmunity as an "enigmatic force ... that is at work wherever the future (of life in general, of the living being, of democracy, of reason itself) is at stake." ${ }^{\prime 9}$ Here we may finally speak of an ethics of autoimmunity (as opposed to an autoimmunity of ethics-as in America's state of ethical disorder after 9/11); autoimmunity, in this context, would entail a radical or unconditional hospitality to the neighbor as radical other (the uncanny neighbor of Judaism, "the neighbor as the bearer of a monstrous Otherness" ${ }^{50}$ ), whose effects on the self cannot be determined fully in advance.

Derrida opposes his rhetoric of hospitality to that favored by France's right-wing politician Jean-Marie Le Pen: "Le Pen's organicist axiom ... only lets in what is homogeneous or homogenizable, what is assimilable or at the very most what is heterogeneous but presumed 'favorable': the appropriable immigrant, the proper immigrant." ${ }^{51}$ In stark contrast, Derrida embraces an infectious understanding of difference, an impure difference irrevocably at odds with the ideological function of "France" as a Master-Signifier, capable of changing France's ontological being by contaminating its mystified organic whole. While Le Pen's nationalist-protectionist ethos, nostalgically holding on to the "symbolic paternal function" 52 (the authority of the big Other), may seem diametrically opposed to the deterritorialized logic of late capitalism and global neoliberal ethos, 
Le Pen and advocates of neoliberalism do share one fundamental phantasm: the immigrant other must be predictable, foreseeable; only under such hermeneutical conditions would this other be most manageable and amenable to assimilation and capitalist exploitation (that is, translatable into human capital).

To conclude, Derrida's "democracy to come" should not be interpreted as a simple return to ethics if by ethics one means to follow Levinas too closely in reducing it to a dyadic relation divorced from the economic and political field of power. Unlike many of his counterparts on the Left, Derrida continues to uphold the virtues of difference; governed by the illogic logic of autoimmunity, difference serves as an ethico-political alternative to the politics of subtraction (captured in the slogan of "indifference to difference"). This alternative, though, ought not to function as a mere substitute for the Left but as an ethical supplement to the political Left in its struggle to disrupt the hegemony of neoliberal rationality. Derrida implicitly invites the Left to resist the all-too-common urge to view ethics as mere ideology, as a retreat from the political proper, and to reconsider the relation between ethics and politics in terms of a double bind, to conceive of ethics and politics through the parallax view-that is, as at once irreducible to one another yet also fundamentally inseparable, tensely linked in a "relation without relation" that binds as it divides.

\section{Works Cited}

Borradori, Giovanna, ed. Philosophy in a Time of Terror: Dialogues with Jürgen Habermas and Jacques Derrida. Chicago: University of Chicago Press, 2003.

Bremer, Paul. “Operation Iraqi Prosperity.” Wall Street Journal, June 20, 2003.

Brown, Wendy. Edgework: Critical Essays on Knowledge and Politics. Princeton: Princeton University Press, 2005.

-. "Sovereign Hesitations." Derrida and the Time of the Political. Pheng Cheah and Suzanne Guerlac, eds. Durham: Duke University Press, 2009.

Dean, Jodi. Democracy and Other Neoliberal Fantasies. Durham: Duke University Press, 2009.

Derrida, Jacques. "Faith and Knowledge: The Two Sources of 'Religion' at the limits of Reason Alone." Trans. Samuel Weber. Acts of Religion: Jacques Derrida. Gil Anidjar, ed. New York: Routledge, 2002. 
—. Negotiations. Elizabeth Rottenberg, ed. Stanford: Stanford University Press, 2001.

—. "Peine de mort et souveraineté." Divinatio 15 (2002).

—. "Remarks on Deconstruction and Pragmatism." Trans. Simon Critchley. Deconstruction and Pragmatism. Chantal Mouffe, ed. London: Routledge, 1996.

-. Rogues: Two Essays on Reason. Trans. Pascale-Anne Brault and Michael Naas. Stanford: Stanford University Press, 2005.

-. Specters of Marx: The State of the Debt, the Work of Mourning, and the New International. Trans. Peggy Kamuf. New York: Routledge, 1994.

—. "Violence and Metaphysics." Writing and Difference. Trans. Alan Bass. Chicago: The University of Chicago Press, 1978.

-. and Maurizio Ferraris. A Taste for the Secret. Trans. Giacomo Donis. Oxford: Polity, 2001.

Foucault, Michel. The Birth of Biopolitics: Lectures at the Collège de France, 1978-1979. Trans. Graham Burchell. New York: Palgrave Macmillan, 2008.

Hägglund, Martin. Radical Atheism: Derrida and the Time of Life. Stanford: Stanford University Press, 2008.

Harvey, David. A Brief History of Neoliberalism. Oxford: Oxford University Press, 2007.

Jameson, Fredric. Postmodernism; Or, the Cultural Logic of Late Capitalism. Durham: Duke University Press, 1991.

Lemke, Thomas. “'The Birth of Bio-Politics': Michel Foucault's Lecture at the Collège de France on Neo-liberal Governmentality." Economy and Society 30.2 (2001).

Naas, Michael. Derrida From Now On. New York: Fordham University Press, 2008

Rancière, Jacques. "Ethics and Politics in Derrida." Derrida and the Time of the Political. Pheng Cheah and Suzanne Guerlac, eds. Durham: Duke University Press, 2009

Rottenberg, Elizabeth. “The Legacy of Autoimmunity.” Mosaic 39.3 (2006).

US Constitution. Art. I, Sec. 9, Cl. 2.

Yoo, John. "War, Responsibility, and the Age of Terrorism." Stanford Law Review 57.3 (2004).

Žižek, Slavoj. “Class Struggle or Postmodernism? Yes, Please!” Contingency, Hegemony, Universality: Contemporary Dialogues on the Left. Judith Butler, Ernesto Laclau, and Slavoj Žižek, eds. London: Verso, 2000. 
-. The Fragile Absolute, or, Why Is the Christian Legacy Worth Fighting For? London: Verso, 2000.

—. The Parallax View. Cambridge: MIT Press, 2006.

—. “The Spectre of Ideology." Mapping Ideology. London: Verso, 1994.

\section{Notes}

1. Paul Bremer, “Operation Iraqi Prosperity,” Wall Street Journal (20 June 2003).

2. As David Harvey puts it, "[Neoliberalism] has pervasive effects on ways of thought to the point where it has become incorporated into the commonsense way many of us interpret, live in, and understand the world." David Harvey, A Brief History of Neoliberalism (Oxford: Oxford University Press, 2007), p. 3.

3. Fredric Jameson, Postmodernism; Or, the Cultural Logic of Late Capitalism (Durham: Duke University Press, 1991), p. 263.

4. Slavoj Žižek, “The Spectre of Ideology,” Mapping Ideology (London: Verso, 1994), p. 1.

5. Slavoj Žižek, “Class Struggle or Postmodernism? Yes, Please!” Contingency, Hegemony, Universality: Contemporary Dialogues on the Left, Judith Butler, Ernesto Laclau, and Slavoj Žižek, eds. (London: Verso, 2000), p. 127.

6. Jacques Derrida, "Faith and Knowledge: The Two Sources of 'Religion' at the limits of Reason Alone," Trans. Samuel Weber, Acts of Religion: Jacques Derrida, Gil Anidjar, ed. (New York: Routledge, 2002).

7. Wendy Brown, Edgework: Critical Essays on Knowledge and Politics (Princeton: Princeton University Press, 2005). I follow Brown here in stressing the interpellative dimension of neoliberal ideology: “ $[\mathrm{N}]$ eoliberalism normatively constructs and interpellates individuals as entrepreneurial actors in every sphere of life". In Democracy and Other Neoliberal Fantasies (Jodi Dean, Democracy and Other Neoliberal Fantasies [Durham: Duke University Press, 2009]), Jodi Dean has called into question this all-too-familiar Althusserian framing of neoliberal ideology; Dean takes from Žižek the critical diagnostic of the postmodern condition as one of fundamental crisis in the symbolic order ("the quasi-transcendental Master-Signifier that guarantees the consistency of the big Other ... is ultimately a fake, an empty signifier without a signified" [Slavoj Žižek, The Fragile Absolute, or, Why Is the Christian Legacy Worth Fighting For? (London: Verso, 2000), p. 106]. With this new era of uncertainty come new forms of political subjectivization, which are, however, not any less controlling or oppressive. In light of the sheer diffusion of new disciplinary sites, which have severely weakened symbolic 
prohibitive norms but significantly increased the production of imaginary ideals, Dean urges us to recalibrate our analysis: "So neoliberal ideology does not produce its subjects by interpellating them into symbolically anchored identities (structured according to conventions of gender, race, work, and national citizenship). Instead, it enjoins subjects to develop our creative potential and cultivate our individuality" (Jodi Dean, Democracy and Other Neoliberal Fantasies, p. 66). While making a compelling case for a taking a more critical look at interpellation as an adequate notion to elucidate the workings of ideology, Jodi Dean's dismissal of interpellation tout court (it is just too outdated) strikes me as unwarranted. Here, Žižek's own engagement with the Althusserian concept seems preferable. Approaching the question of interpellation from its putative other-disidentification (what happens when one refuses the "hail" of interpellation, when one refuses to assume the symbolic place imposed on us by the big OtherŽižek deconstructs the latter's subversive aura. He perspicaciously asks: “[I] $\mathrm{s}$ disidentification necessarily subversive of the existing order, or is a certain mode of disidentification, of 'maintaining a distance' towards one's symbolic identity, consubstantial with effective participation in social life?” (Slavoj Žižek Contingency, Hegemony, Universality, p. 9). It is precisely the oscillation between success (identification) and failure (disidentification) that makes interpellation as such all the more irresistible and powerful, duping the overtly confident critic who thinks he or she has de-masked, blocked or explained away interpellation's originary mode of identification.

8. For a genealogy of homo economicus, see Thomas Lemke, “'The Birth of BioPolitics': Michel Foucault's Lecture at the Collège de France on Neo-liberal Governmentality," Economy and Society 30.2 (2001); and Michel Foucault, The Birth of Biopolitics: Lectures at the College de France, 1978-1979, Trans. Graham Burchell (New York: Palgrave Macmillan, 2008).

9. Giovanna Borradori, ed., Philosophy in a Time of Terror: Dialogues with Jürgen Habermas and Jacques Derrida (Chicago: University of Chicago Press, 2003), p. 94.

10. Jacques Derrida, Rogues: Two Essays on Reason, Trans. Pascale-Anne Brault and Michael Naas (Stanford: Stanford University Press, 2005), p. 34.

11. Ibid., p. 123.

12. John Yoo, "War, Responsibility, and the Age of Terrorism," Stanford Law Review 57, 3 (2004), p. 816.

13. US Constitution. Art./Amend. I, Sec. 9, Cl. 2.

14. Wendy Brown, Edgework, p. 47.

15. Jacques Derrida, Specters of Marx: The State of the Debt, the Work of Mourning, and the New International, Trans. Peggy Kamuf (New York: Routledge, 1994). 
16. Jacques Derrida, Specters of Marx, p. 85.

17. Wendy Brown, "Sovereign Hesitations," Derrida and the Time of the Political, Pheng Cheah and Suzanne Guerlac, eds. (Durham: Duke University Press, 2009), p. 126.

18. Jacques Derrida, Rogues, p. 153-154.

19. Wendy Brown, “Sovereign Hesitations,” p.125

20. Ibid., p. 125

21. Jacques Derrida and Maurizio Ferraris, A Taste for the Secret, Trans. Giacomo Donis (Oxford: Polity, 2001), p. 27.

22. Jacques Derrida, "Violence and Metaphysics," Writing and Difference, Trans. Alan Bass (Chicago: The University of Chicago Press, 1978), p. 151.

23. Ibid., p. 84 .

24. Ibid., p. 84 (emphasis added).

25. Jacques Derrida, Rogues, p. 60.

26. Jacques Rancière, "Ethics and Politics in Derrida," Derrida and the Time of the Political, Pheng Cheah and Suzanne Guerlac, eds. (Durham: Duke University Press, 2009), p. 284.

27. Jacques Rancière, “Ethics and Politics in Derrida,” p. 284.

28. Ibid., p. 278.

29. Unlike the phantasm of nationalism or sovereignty - understood as the problematic expressions of an ideological and metaphysical desire for purity-Derrida's "phantasm" of pure ethics is self-consciously staged, subjected to (self)irony and deconstruction. For an insightful account of Derrida's preoccupation with the nature of phantasm, see Michael Naas, Derrida From Now On (New York: Fordham University Press, 2008).

30. Jacques Rancière, “Ethics and Politics in Derrida,” p. 283.

31. Ibid., p. 278.

32. Žižek shares Rancière's dismissal of Derridean postmodern politics; despite being drawn to Derrida's earlier notion of différance, he insists on "draw[ing] an even stronger line of demarcation from the usual gang of democracyto-come-deconstructionist-postsecular-Levinasian-respect-for-Otherness suspects” (Slavoj Žižek, The Parallax View [Cambridge: MIT Press, 2006], p. 11). This gross conflation of Derrida's and Levinas' views compounds Žižek's misreading of the Derridean idea of democracy to come. Moreover, Derrida himself, in Rogues, links his earlier notion of différance with that of democracy to come (Jacques Derrida, Rogues, p. 8-39, 84). 
33. Slavoj Žižek, The Parallax View, p. 17.

34. Ibid., p. 4.

35. Ibid., p. 5.

36. Giovanna Borradori, Philosophy in a Time of Terror, p. 120.

37. While describing democracy's autoimmunity as a "nondialectizable antinomy" (Jacques Derrida, Rogues, p. 35), Derrida conceives here of dialectics in its traditional sense of a logic that overcomes tension, seeking self-presence and closure.

38. Slavoj Žižek, The Parallax View, p. 6.

39. Jacques Derrida, Rogues, p. 25.

40. Giovanna Borradori, Philosophy in a Time of Terror, p. 134.

41. Ibid., p. 134.

42. Jacques Derrida, “Remarks on Deconstruction and Pragmatism,” Trans. Simon Critchley, Deconstruction and Pragmatism, Chantal Mouffe, ed. (London: Routledge, 1996), p. 85; and Jacques Derrida, "Faith and Knowledge.”

43. Jacques Derrida, Negotiations, Elizabeth Rottenberg, ed. (Stanford: Stanford University Press, 2001); Jacques Derrida, "Peine de mort et souveraineté," Divinatio 15 (2002), p. 18.

44. Jacques Derrida, Rogues, p. 109.

45. (Giovanna Borradori, Philosophy in a Time of Terror, p. 191n.14) "What must be thought here ... is this inconceivable and unknowable thing, a freedom that would no longer be the power of a subject, a freedom without autonomy, a heteronomy without servitude" (Jacques Derrida, Rogues, p. 152).

46. Giovanna Borradori, Philosophy in a Time of Terror, p. 80n27.

47. Derrida even images God as "a vulnerable nonsovereignty" (Jacques Derrida, Rogues, p. 157). As Martin Hägglund puts it, "[Derrida] holds that God is as dependent on temporal finitude as everyone else” (Martin Hägglund, Radical Atheism: Derrida and the Time of Life [Stanford: Stanford University Press, 2008], p. 143).

48. Jacques Derrida, Rogues, p. 152.

49. Elizabeth Rottenberg, “The Legacy of Autoimmunity.” Mosaic 39.3 (2006), p. 5.

50. Slavoj Žižek, The Parallax View, p. 113.

51. Jacques Derrida Negotiations, p. 102.

52. See endnote 205 (David Harvey, A Brief History of Neoliberalism). 


\section{II}

Literature, Culture, and the Self 
Chapter 6

\section{Complexity as Capture Neoliberalism and the Loop of Drive}

Jodi DeAN

Real existing neoliberalism reconfigures elements of multiple discourses. By neoliberalism, I mean not simply the ideological program of the Chicago school and its adherents in government and business but rather the broader cloud of distributed suppositions and practices through and within which capitalist reality takes its particular neoliberal format. Some of the elements from differing discourses that neoliberalism configures include frontier myths of heroic individuals, new media celebrations of fast and fluid networks, fantasies of free markets, misplaced critiques of collective ownership and government regulation, as well as confusions between the economic concept of competition and competition understood as a rivalry or contest. There are others. ${ }^{1}$ In this essay, I highlight two additional components of the neoliberal atmosphere-reflexivity and complexity.

Reflexivity and complexity show up as assumptions regarding neoliberalism's basic setting. Insofar as these assumptions traverse politics, economics, science, philosophy, and media theory and insofar as their academic and popular applications crisscross, reflexivity and complexity seem to point to fundamental truths about thinking and being. They seem so obvious and uncontestable that only an idiot would question them. Since at least Descartes (though some might say Socrates), reflexivity has been a primary feature of reason (not to mention a necessarily constitutive element of critiques of reason). ${ }^{2}$ Most critical academics as well as most economists and financial analysts link reason to self-consciousness 
and give this link a moral valuation. Most critical academics as well as most economists and financial analysts likewise embrace a general notion of complexity (if not all the specifics of complexity theory). Even as they may differ on the relative power of models and abstractions (and hence of the explanatory value of cellular automata and similar computer experiments), these academic and financial types share a weak ontology of interconnectivity, mutual causality, contingency, and singularity (the unique qualities of individuals, persons as well as non-persons). Everyone knows that there are always exceptions, different experiences, improbable results. The world exceeds our attempts to explain it. It's complex. ${ }^{3}$

To consider the ways assumptions of reflexivity and complexity contribute to the configuration of neoliberalism, I use the psychoanalytic category of "drive." In so doing, I employ and extend some ideas from Slavoj Žižek, specifically, his upgrade of ideology critique via the later seminars of Jacques Lacan. As is well known, Louis Althusser taught that the category of the subject is constitutive of ideology. But what kind of subject or the subject in what sense is constitutive? Perhaps the most widely accepted answer to this question emphasizes the subject of desire, particularly as theorized by Lacan. The subject emerging through ideological interpellation is said to be a desiring subject, its desire a product of the intervention of the law that prevents it from getting what it wants, thereby insuring the openness of desire. Žižek's version of ideology critique reaches beyond the subject of desire to consider the subject of drive. Here the subject is understood as a remnant or effect of the failure of ideological interpretation, the ineliminable gap exceeding ideology's efforts to determine its subjects. ${ }^{4}$

One way to get at the difference between the subject of desire and the subject of drive is to highlight each's relation to the object. As Žižek explains, desire is for a lost object. In contrast, in drive loss itself is an object. ${ }^{5}$ Drive, then, is the force of loss. For example, capitalism expresses this force of loss as an absence of completion or limits. Capital is only capital through the loss of a capacity to be at rest (money under a mattress, money that can't be invested or put to work, isn't capital). Absent an end or a limit, capitalism pushes on, in a relentless, nonsensical circuit. The theoretical benefit of the move from the concept of desire to the concept of drive is that critique can explore not just what we want but can 
never attain (the economy or logic of desire), but what we cannot avoid, no matter how hard we try (the economy or logic of drive).

Desire alone can't account for the persistence of capitalism. Capitalism cannot be reduced to our desire for it. Rather, capitalism persists as a system of practices in which we are caught. Žižek writes, "Drive inheres to capitalism at a ... systemic level: drive is that which propels the whole capitalist machinery, it is the impersonal compulsion to engage in the endless circular movement of expanded self-reproduction." ${ }^{\text {C Capital }}$ strives to accumulate, to reproduce itself. It circulates, ceasing to be capital if this circulation stops. I use drive to analyze the extreme capitalism of neoliberalism, a specific historical formation in which the limits to capitalism brought about through a century of working class struggle have been undone in the course of political victories by capitalists acting as a class. By exploring reflexivity and complexity in terms of drive, I hope to illuminate some of the specific ways neoliberalism captures its subjects and thus formats the terrain of contemporary class struggle.

\section{Drive}

I begin with a brief sketch of drive. In his classic work on drive, Sigmund Freud attributes four vicissitudes to the drives (unfortunately translated as "instincts"): reversal into its opposite, turning round upon the subject's own self, repression, and sublimation. ${ }^{7}$ Freud's uses scopophilia, voyeurism, as an illustration. More than just a desire to look, scopophilia is accompanied by a drive to be seen. Looking or seeing reverses into exhibitionism. The voyeur doesn't get off just by seeing. The voyeur wants to be seen seeing. This reversal into "being seen" converges with the second vicissitude: it is a "turning round upon the subject's own self." The self becomes the object (what is seen). As it does so, its activity is transformed into passivity. The object to be seen is replaced by the subject who is seen (and who is now the object being seen). Holding onto a conception of the object qua object thus misses the point. What matters is the reversal, the reflexive turning round back onto the subject.

Freud's third and fourth vicissitudes likewise converge. The third, repression, is a kind of dam. Dammed up water can overflow into a network of tributaries, breaking out in multiple directions. Like water 
creating new channels, the drives, Freud explains, are "extraordinarily plastic." "They may appear in each others' places. One of them may accumulate the intensity of the other." Sublimation, the fourth vicissitude, is this finding of new outlets, new paths of expression, for the repressed desire. Indeed, drive is only expressed as sublimated, as an effect of repression. And while this effect takes the form of a circuit (turning round upon the subject's own self), the circuit isn't closed; it's open, plastic, capable of moving among and attaching to different objects as so many outlets or opportunities for enjoyment (sublimation). Drive is a circuit that in the course of its movement outwards and back can alter, shift, disperse and branch.

The reflexive movement drive designates is a loop, a loop that is less a circle or oval than a messy spiral or fractal. Similarly, the loop of drive isn't fixed or balanced; it's an uneven repetition and return that misses and errs. As Lacan explains, drive is "beyond the instinct to return to a state of equilibrium." In other words, drive isn't a force through which the subject achieves some kind of steady state. Stuck in the loop of drive, the subject tries to get the same result by doing the same thing over and over, but fails. Still, the subject gets something, a little bit of enjoyment (jouissance), in the repeated effort of trying. This little bit of enjoyment is enough of a payoff for the subject to keep on keeping on, although each moment is a little different. Why is each movement a little different? Because it comes next; it adds itself and thereby changes the setting of the next circuit. So in addition to reversal and dispersion, the movement of drive involves accumulation, amplification, and intensification.

Consider slot machines. People ostensibly play the slots because they desire to hit the jackpot. This desire alone, however, can't account for the appeal of slot machines, as if slot machines were vehicles for players' rational calculations of expected financial return given a specific expenditure of capital. Instead, slot machines are assemblages for and of the drive. They rely on little pleasures of anticipation, seeing pictures disappear and appear, experiencing the little rush of noise and lights, being seen by others as one who might be the big winner. Each pull of the handle occurs at a different moment, so no pull is exactly the same. Our anticipation with the fourth pull may be invested with more excitement and delight than we have at the ninth one, when we might be anxious, 
worried about how much we've put in the machine. By the fortieth pull, our attachment to the machine, our capture in the circuit of drive, has disruptive effects of its own, making us late for dinner or unable to pay our phone bill. What we started for pleasure, perhaps as a way to escape from the constraints of pragmatic day-to-day responsibilities, reverses into something from which we want to escape but can't (which is why, incidentally, Lacan rejects Freud's distinction between eros and thanatos; drive is a loop rather than something than can be bifurcated into a positive and negative force).

Because drive designates a turning back upon one's self, it provides a concept for theorizing reflexivity at the level of the subject. A keeping on beyond pleasure, beyond use, beyond desire, drive makes reflexivity appear as a circuit or loop in which the subject is caught, thereby disrupting the assumed coincidence of reflexivity and reason. Mark C. Taylor's definition of reflexivity is helpful here: "Reflexivity is a nonlinear relation in which cause and effect are interdependent: the thoughts and actions of agents influence the operation of the system, which, in turn, influences the thoughts and actions of agents." ${ }^{10}$ Just as the way scopophilia becomes exhibitionism and the subject becomes the object, so does reflexivity involve a loop or turn. This looping or turning marks an unpluggable, unavoidable gap, a kind of "halting problem" as an irreducible feature of a consciousness conscious of and anxious before its constitutive limit (in computer programming, a halting problem arises when a program gets to a point where its only options are stopping arbitrarily or running infinitely; children play with this problem when they invoke reflexive loops like "I know that you know that I know that you that I know...). Conceiving the reflexive turn via the loop of drive draws our attention to our capture in the picture we ourselves draw, the loop we ourselves designate. Rather than an operation that can come to an end or answer, reflexivity oscillates between an eliminable choice between the arbitrary and the infinite. Drive marks our enjoyment of this oscillation (and, conversely, oscillation here points to the fact of enjoyment). It indexes not only the inclusion of the observer in the system but the entrapment of the observer as a somatic and mental entity that enjoys. We constitute the circuits, processes, tactics, operations, and systems that constitute us even as this constitution is less a matter of choice than a 
matter of dynamic fixation. We are features of self-constituting systems. The emphasis on drive is thus a way to retain knowledge, knowing, and enjoyment as effective components of material networks.

\section{Reflexivity}

Although analysts of the recent expansion and collapse in the finance sector rarely use Lacanian psychoanalysis to explain why it happened, they frequently invoke bubbles, feeding frenzies, and feedback loops. They appeal, in other words, to the extremes and ruptures brought about by reflexivity in complex networks. Financier George Soros is most explicit on this point, theorizing reflexivity as the two-way connection between participants' views and their situation and analyzing the crisis in terms of this two-way connection. ${ }^{11}$ As he makes clear, reflexivity contributed to the recent financial crisis in multiple, reinforcing ways. I emphasize three: risk management, derivatives, and poverty.

1) Risk management. In the nineties, financial firms began to assess the amount of capital that they needed to have on hand to back up their investments in terms of "value at risk" (VAR). VAR is a single number that lets a bank determine how far its portfolio can drop in a single day. ${ }^{12}$ VAR is calculated in terms of asset volatility-how much an asset's price jumps around in a given time period. The assumption is that price movements vibrate within a standard deviation; their distribution takes the form of a bell curve. Armed with their VAR, banks can calculate how much capital they want to carry in light of their overall risk exposure. Seeking to escape from government determined standards of acceptable risk, financial firms in the nineties argued that their investment strategies were better pegged to the market. ${ }^{13}$ Rather than sitting dormant as an unnecessary back-up or safety measure, their capital could be leveraged to create more opportunities for the generation of wealth. VAR would let them know what they could reasonably risk.

One problem with this approach to risk arises from its adoption by numerous parties. ${ }^{14}$ Presuming that they and their trading partners have taken appropriate measures to insure against risks, firms and money managers are likely to think they are more secure than they actually are (and, indeed, some blamed portfolio insurance for Black Monday, the 508 
point drop in the Dow on October 19, 1987). ${ }^{15}$ For example, they may assume that diversifying their holdings provides sufficient protection against declines in a particular asset class since prices of different assets tend to move in opposing directions (they are negatively correlated). In extreme circumstances, however, everything might start to drop. Why? Because a firm trying to protect itself from losses in one area starts selling assets in a second area in order to maintain its VAR. This selling pushes down the price of this second area, which begins or can begin a further downward cascade, particularly insofar as other firms see prices falling in this new area and don't want to get slammed there as well as in the first area. The dynamic is reflexive in that relies on the fact that observers of the system are agents in the system. So it's not only a matter of what a given firm is doing. It is also a matter of the firm's (always partial and distorted) knowledge of what it is doing, its knowledge that others have knowledge or expectations of what it is doing, and its entrapment in the loop of this knowledge of knowing.

2) Derivatives. Closely linked to risk management are derivatives, the class of custom-made financial tools such as commodity futures, stock options, currency swaps, credit default swaps, and collateralized debt obligations that let traders insure or bet against movements in other financial instruments. ${ }^{16}$ As a class, derivatives have three key attributes: they are limited term contracts to exchange capital in an agreed upon description of the future on the basis of the price of the underlying asset at that time ("limited term" here means that the contract has an expiration date. $)^{17}$ Most derivatives trade privately in the unregulated over-thecounter or OTC market. The face value of derivates rose from 866 billion dollars to 454 trillion dollars between 1987 and $2007 .^{18}$

Derivatives exemplify reflexivity in a number of ways. First, the derivative instrument itself is reflexive: it steps back from an asset's relation to its setting to bet on how investors will assess that relation in the future. It's not just a bet; it's a bet on how others will bet.

Second, this reflexivized bet itself contributes to producing the future on which it is betting. Derivatives enable enormous leveraging. Small outlays of capital can have huge pay-offs or pay-outs in the future. Because the immediate cost of risk is comparatively small, firms can undertake more investments than they would with regular stocks and bonds. ${ }^{19}$ 
Derivatives also contribute to the future on which they are betting insofar as they require counterparties. Someone has to be on the other, losing, side of the deal. Complex derivatives combine, slice up, recombine, and sell bundles of assets (J. P. Morgan designed synthetic CDOs; there were also CDOs of CDOs and CDOs of CDOs of CDOs).$^{20}$ From one perspective, these recombinant financial instruments distribute risk so broadly that no one firm suffers too badly when an investment sours. From another perspective, the multiplication of counterparties exposes more firms to investments gone wild. Because derivatives "tighten intermarket connectivities," turbulence more easily flows from one market into another, making it "increasingly difficult to inoculate a market against potential damage." ${ }^{1}$

A third way that derivatives exemplify reflexivity is in their relation to their setting in the circulatory regime of global capital. Derivatives emerge out of the perceived need to protect against the risks involved in complex speculative financial transactions even as they make these transactions possible and thereby produce, retroactively, their own conditions of emergence. In the words of LiPuma and Lee, "once the speculative capital devoted to financial derivatives becomes self-reflexive and begins to feed on itself, it develops a directional dynamic toward and autonomous and self-expanding form." ${ }^{22}$ The circulation of money detaches itself from production; money is purely self-mediating. Since abstract financial relations are themselves treated as underlying assets, money markets can expand seemingly without limit-that is, as long as everyone involved believes that they will, as long as the circuit keeps on going on and no one tries to cash in or call.

Consider the synthetic collateralized debt obligation. This is a CDO comprised of credit-default swaps, insurance on tranches of bonds that pays when the bonds' prices decline. As Michael Lewis explains, “The market for 'synthetics' removed any constraint on the size of risk associated with subprime mortgage lending. To make a billion-dollar bet, you no longer needed to accumulate a billion dollars worth of actual mortgage loans. All you had to do was find someone else in the market willing to take the other side of the bet." ${ }^{23}$ For derivatives such as synthetic CDOs, risk is not primarily a side effect of complex, interlinked market 
transactions. Rather, risk is deliberately and intentionally configured into a securitizable object.

When a market is made for a specific designer instrument, like a CDO or a credit default swap, the surplus risk shifts from being a byproduct to being the product; it occupies the place previously held by the asset. Thomas Adams and Yves Smith bring the point home as they trace the incentive to make bad loans that drove the massive expansion of the $\mathrm{CDO}$ market. The riskiest tranches of a CDO are the ones with the highest potential reward. Investors, particularly hedge funds and others looking for something to short, wanted them, so banks looked for more bad loads to buy, which stimulated more brokers to issue more mortgages to anyone who would take them. In the words of Adams and Smith:

Dozens of warning signs, at every step of the process, should have created negative feedback. Instead, the financial incentives for bad lending and bad securitizing were so great that they overwhelmed normal caution. Lenders were being paid more for bad loans than good, securitizers were paid to generate deals as fast as possible even though normal controls were breaking down, CDO managers were paid huge fees despite have little skill or expertise, rating agencies were paid multiples of their normal MBS fees to create CDOs, and bond insurers were paid large amounts of money to insure deals that "had no risk" and virtually no capital requirements. All of this was created by ridiculously small investments by hedge funds shorting MBS mezzanine bonds through CDO structures. ${ }^{24}$

The financial crisis that started in the housing market and spread throughout the finance sector and into the broader economy was an effect of reflexivity-reflexivized risk.

3) Poverty. My third example of the role of reflexivity in the recent crises in the finance markets concerns poverty, inequality, and debt. ${ }^{25}$ Although per capita GDP in the US nearly doubled between 1976 and 2005 , about half the gains went to the top one percent of the population. ${ }^{26}$ Real median wage remained stagnant. Any small increase to the middle class households during the "lost decade" was the result of more hours worked, whether as an effect of the increase in dual income households 
or of declines in vacation time. Debt addressed the decline in purchasing power experienced by the majority of people.

As I've mentioned, debt also had the benefit of being securitizable and thus available as an investment vehicle for the excess of capital at the top. In Michael Lewis' words, "Complicated financial stuff was being dreamed up for the sole purpose of lending money to people who could never repay it." ${ }^{27}$ The expansion in the number of subprime mortgages, their bundling into bonds, the bonds' dividing into tranches, the tranches' repackaging into CMOs (collateralized mortgage obligations) and CDOs (which included debts besides mortgages such as student loans and credit card debts) resulted from demand for these massive financial instruments. Working people's desire to purchase homes they could not afford did not create CDOs (as media accounts blaming mortgage defaults on low income people sometimes make it sound). Investment banks did. Scott Patterson puts it bluntly, "without the demand from the investment banks, the bad loans would never have been made." ${ }^{28}$ Michael Lewis agrees: the mortgage holders "existed only so that their fate might be gambled upon." ${ }^{29}$

Investment banks used CDOs to remove debt from their balance sheets. They sold this debt to investors in the form of tranches of the CDOs. Most investors thought they were buying measurable risk. Those who purchased tranches with AAA ratings from Moody's or Standard \& Poor's thought they were investing in something pretty secure with a very, very low likelihood of failure, primarily because the likelihood of default on a large number of mortgages was very, very low. AAA tranches were particularly attractive for pension funds and university endowments required to keep their risk exposure low.

The problem was that the models used to figure out the correlations between the tranches not only assumed predictable, bell-curve like patterns in the data, but also ignored the fact that the price information fed into the models was coming from a bubble in the housing market. The housing bubble was inflated by historically low interest rates after 9/11, the rush of investors wounded in the burst of the dotcom bubble into ostensibly secure real estate, banks' enthusiasm for mortgages and other loans that generated lots of fees, and the rise of derivatives themselves. ${ }^{30}$ Scott Patterson explains that the result was "a vicious feedback loop-an 
echo chamber, one might say, in which enthusiastic investors snapped up tranches of CDOs, creating demand for more CDOs - and that created a demand for more mortgage loans." 31

Demand for CDOs corresponded to the rise in inequality. Prior to the subprime mortgage boom, subprime mortgage lending was a fairly sleazy business, selling off its loans with little to no regard for whether they could be repaid, charging lots of fees to its high-risk customers, relying on teaser rates that would balloon up after a couple of years. Most of these early lenders went bankrupt in the mid-nineties. Less than a decade later, the subprime market was larger than before, offering even lower quality mortgages to people who, facing a decade of stagnant wages and maxed out credit cards jumped at the chance of no money down, interest only mortgages. ${ }^{32}$ The debts of poor and working people were useful, fodder for the Wall Street finance machine. So even though adjustable-rate mortgages were defaulting at epic rates in 2005, the price of houses continued to rise, the subprime mortgage market continued to expand, and the price of credit default swaps fell. The massive financial boom required, was made possible by, the debts of the people seemingly furthest from Wall Street, those considered the least credit-worthy. At this interface of the extremes of profit and loss, poverty (like risk) isn't an unavoidable byproduct of financial, speculative capitalism but its condition and content. In the circuit of amplified inequality, the increase in the number of poor people isn't a social problem, it's an investment opportunity. The system turns in on itself and feeds on its own excesses.

Even in the last months of the bubble in subprime mortgage bonds (between February and June of 2007), the market in CDOs continued to generate billions. In the words of one analyst (and short-seller): "it was like watching an unthinking machine that could not stop itself." ${ }_{33}$ To be sure, there was ever-increasing turbulence as banks tried to get rid of bad investments before they collapsed. But insofar as buyers kept purchasing them (and firms like Bear Stearns and Lehman Brothers continue to emphasize the soundness of the bonds), the market remained afloat. Michael Lewis' description suggests the trap of drive: "it was as if an entire financial market had tried to change its mind-and then realized that it could not afford to change its mind." 34 The interconnected banks were caught in a circuit beyond their control. If there were no buyers for 
the CDOs, and the mortgages deep in their bowels were defaulted upon as house prices continued to drop, the CDOs would be worth nothing. The credit-default swaps were ostensibly a kind of insurance, a way to hedge against massive losses, but that hedging depended on the seller's ability to pay. If the seller couldn't pay, then the insurance wasn't worth anything either. In effect, the over-leveraged derivatives market, a substantial component of Wall Street's exorbitant profits and bonuses, led the financial system to deceive itself.

The effect of the assemblage of incentives, rewards, penalties, egos, debts, mortgages, models, computers, hormones, and wagers was a financial crisis of epic proportions. The global financial meltdown and resulting recession, unemployment, and indebtedness, particularly of governments subsequently pressured to eliminate social services, expose the specificity of neoliberal capitalism as a circuit in which reflexivity is a mechanism of capture rather than reason, where the loop of drive amplifies the worse tendencies rather than employs feedback as a mechanism of self-correction. Neoliberalism is thus neither a formation well-defined in terms of free, unregulated markets nor one well-understood in terms of competition as a moderating force.

As Michel Foucault explains already in his lectures on the birth of biopolitics, neoliberalism is a governmentality that intervenes in markets, that creates them, that governs in their behalf. ${ }^{35}$ Its conceit is not liberalism's laissez faire approach to markets but instead an ensemble of policies and interventions resulting from the subjection of the state of the market. ${ }^{36}$ Foucault is less accurate when he describes these interventions as attempts to induce and protect competition (neglecting capitalism's already well-documented tendency toward monopoly). Contemporary financial markets might be cut-throat, blood-thirsty, but they aren't competitive, not if by competitive we imagine some kind of open contest with clear, fair rules. I should add here the mistake with another assumption regarding neoliberalism, namely, that it is linked to consumerism. The emphasis on consumption might have highlighted a feature of Fordism, particularly insofar as Fordist economic strategies depended on keeping wages high enough for consumers to purchase the goods they produced. In contrast, neoliberalism relies on the inequality of rich and poor-a point explicitly acknowledged in the notorious 
Citigroup report, "Revisiting Plutonomy: The Rich Getting Richer." ${ }^{37}$ A set of recommendations for investors to buy stock in luxury goods, private banks, and financial services (a group of stocks the authors refer to as the "plutonomy basket"), the report points out the insignificance of poor and middle class consumers. The only consumers who matter are rich ones, the ones who have been benefiting and can be expected to continue to benefit from neoliberal globalization. The rich drive demand (not the mass of middle and working class consumers). The rich have an increasingly larger share of income and wealth and thus greater proclivity to spend. In the words of the report, "Asset booms, a rising profit share and favorable treatment by market-friendly governments have allowed the rich to prosper and become a greater share of the economy in the plutonomy countries." The super-rich purchase luxury items and investment vehicles. The poor rely on cheap, low quality goods and massive amounts of corn, that is, the sub-standard food of corporate agriculture. For everything else, there is debt, the debt the finance sector needs to function.

\section{Complexity}

We are regularly told that financial instruments like collateralized debt obligations and credit default swaps are beyond our comprehension. Not only are they too hard for average citizens to understand, but Alan Greenspan couldn't even understand them. In fact, as hundreds of lobbyists for the finance sector have ceaselessly worked to teach US members of Congress, derivatives can't be regulated, precisely because no one understands them. Beyond comprehension, they are beyond control. Complexity disposes of politics because nothing can be done.

Initially, finance porn (I have in mind here mainstream media treatment of the finance sector as well as the multiple books on the subprime mortgage crisis) lauded "quants" as the ones who actually knew what was going on. These nearly magical geeks, siphoned off from academe, used their advanced mathematics and high powered computers to identify statistical anomalies and price differentials and quickly capitalize them. The economic theory at the basis of their calculations, the Efficient Market Hypothesis, cast these profiteering moves as necessary and ethical: 
buying up underpriced assets helped move their prices to their proper place, back to equilibrium.

Other wizards then came up with alchemical strategies for managing risk, strategies that involved lots of borrowing (leverage) and shifting (structural investment vehicles). Many CDOs were new combinations of slices of other CDOs that a bank had created but had been unable to sell. CDOs' interrelation was circular; they contained each other yet were somehow able to transform this mutual containing into gold (with regard to the CDOs built out of subprime mortgage bonds, the supposition was that real estate would nearly always rise in value, that any declines in the housing market would be local rather than national, and that mortgage backed securities distributed risk so broadly as to dissipate it almost completely; each one of these assumptions ended up being wrong). The CDOs' opaque, exotic names, names that refuse any concrete relation with their contents-Abacus, Carina, Gemstone-heighten the sense that one is approaching the inner sanctum of finance's arcane mysteries. ${ }^{38}$ At the heart of finance are impossible objects that create money. A Goldman Sachs trader described them in an email to his lover as "a product of pure intellectual masturbation, the type of thing which you invent telling yourself: 'Well, what if we created a 'thing,' which has no purpose, which is absolutely conceptual and highly theoretical and which nobody knows how to price?"39 A financial product that exceeds the market, a product beyond valuation, the synthetic CDO is a real abstraction (particularly when one keeps in mind that investors' demand for CDOs created banks' demand for mortgages to back them which led to the issuing of ever more sleazy and predatory loans to vulnerable and low income people).

The powers-that-be allegedly at the helms of the big investment firms-Bear Stearns, Lehman Brothers, Merrill Lynch, Citigroup, Goldman Sachs - have claimed that they both knew and didn't know what was going on as the financial markets heated up and burned out. On the one hand, their risk management strategies necessarily involved all sorts of bets and plans on what could happen. Their justification for the creation of credit default swaps (CDSs) was protection, security, prevention of the worst. On the other hand, the bankers and regulators have all claimed that the crisis was the once-in-a-century event that no one could 
have predicted. Under questioning at the Congressional hearings on the financial crisis, legendary investor Warren Buffett (chief shareholder in Moody's ratings agency) said that he didn't know what Moody's was doing. He didn't know that the agency was making massive mistakes in rating mortgages and bonds before the crisis. Neither he nor anyone else could be expected to know. His own business is too complex for him to understand. ${ }^{40}$ Overrun by mutually influencing dynamics, expectations, unintended consequences, and unknown unknowns, contemporary finance is a domain so complex that no one should even be expected to be able to understand it. The hand of the market isn't simply invisible. It cannot be known or understood by mere mortals (although sometimes those with the right stuff, Tom Wolfe's masters of the universe, might be able to ride it successfully for a while).

The appeal to complexity displaces accountability. The big banks are not accountable because there were all sorts of things they couldn't account for. To be sure, they can enjoy complexity, getting off on the obscure objects they create, abstracting themselves from the debts out of which the objects are made, from the risks that are taken with pension funds and municipal bonds, reveling in a sense that their power puts them above it all. This is the sense, incidentally, at the heart of the culture of extreme bonuses, the only sense such excess makes. Outlandish bonuses inscribe the surplus inequality before which politicians and press bow down. Merely grossly unequal salaries would still inscribe the bankers in the same world as the politicians, an economic world based in labor, production, and commodities rather than a financial world based in fantasies, bets, risks, and will.

The appeal to complexity is a site of convergence between despotic financialism and critical theory (I'm using the term broadly here to encompass contemporary continental and post-Marxist developments in philosophy and political theory). Some critical theorists associate responsibility with sovereign subjectivity and moralizing impulses to punish. The mistake both they and the bankers make is assuming that responsibility implies total knowledge, total control, or total determination of outcomes. Both argue that since the world is more complicated than this, since our networked interactions implicate us in relations and 
outcomes beyond our knowledge and determination, accountability cannot rightly be localized.

Jane Bennett is attuned to the complexity of assemblages constituted out of human and non-human actants, assemblages like those mixing "coal, sweat, electromagnetic fields, computer programs, electron streams, profit motives, heat, lifestyles, water, economic theory, wire, and wood" into an electrical grid. ${ }^{41}$ Given this complexity, she finds the invocation of agency and strong responsibility to be "tinged with injustice." "In a world of distributed agency," Bennett argues, "a hesitant attitude toward assigning singular blame becomes a presumptive virtue." ${ }^{42}$ As I see it, this hesitation corresponds with attitudes dominant in the neoliberal cloud. For examples, we might add to the abundant and proliferating crises in the finance sector the strings of failure dispersed in the wake of Hurricane Katrina, connected with the ill-conceived and aggressive war in Iraq, and gushing from British Petroleum's deep water oil rig in the Gulf of Mexico. Even as each instance resists confinement into a singular moment or single individual decision, decisions of boards, regulators, investors, voters, politicians, consultants, and officials are made, nonetheless. The oil rig didn't emerge spontaneously out of the ocean. The city of New Orleans didn't somehow lose organizational capacities previously put to use in Super Bowl football games and Mardi Gras celebrations. ${ }^{43}$ Some decisions are rightly described as bets or gambles, wagers for one future rather than another. Winners commend themselves for their prescience, presenting their good fortune as grounds for promotion, re-election, praise, a generous bonus. This commendation seems almost appropriate because of the risk of error-they could have been wrong. Blame, condemnation, and punishment are likewise appropriate for those on the losing side of the bet. They had to make a judgment under conditions that were fluid, changing, interconnected, and uncertain-the conditions of any human judgment.

Bennett is right to emphasize the dispersion and distribution of agency: decisions are intermeshed, mashed-up so as to resist confinement into specific, separable choices. Agency is an effect of a larger set of relations. It often feels as if decisions have always been already made, as if we have no real choice, as if the current or process or circuit is in motion and there's nothing we can do to stop it. But we are nonetheless 
accountable for this sense. It's part of the setting of our choices. We are accountable because we can be wrong, because we lack knowledge, control, and the capacity fully to determine outcomes. Responsibility arises because one has to choose not only when one does not know but when one cannot know.

Franco "Bifo" Berardi takes a view of complexity in line with Bennett's: "the complexity of the global economy is far beyond any knowledge and possible governance." Accordingly, he argues that "the political and economic knowledge we have inherited from modern rationalist philosophy is now useless, because the current collapse is the effect of the infinite complexity of immaterial production..." 44 I disagree. To say that the global economy is beyond knowledge and governance cedes in advance a terrain of struggle, a terrain that banks and corporations find important enough to spend millions upon millions to defend. Regulating derivatives isn't impossible-make them illegal. Treating food as a commodity to be speculated upon isn't necessary and unavoidable-forbid it. Banks can be nationalized and required to back permitted investment with adequate capital reserves. Whose purpose does it serve to pretend that this can't be done? Bankers benefit from our thinking that there are operations and processes that compel our obedience, like so much absolutist mystical arcana. They also benefit when we slip into thinking primarily in terms of immaterial production, a kind of derivative thinking that fantasizes value in the absolutely conceptual and without price, in the enjoyment that accrues through adding, repeating, and circulating.

Given the convergence between finance and critical theory around the notion of complexity, it's not surprising to find an overlap with Friedrich Hayek. The rejection of accountability, of politics, repeats his argument against economic planning: we cannot know. For Hayek the problem of the economy is a problem of knowledge. As he points out, economic knowledge is widely distributed; much of it is local, a matter of the availability of materials and workers and infrastructure. Economic knowledge is also subject to constant change. Infinite particulars of time and place, chance and circumstance, call for constant modulation. "It would seem to follow," Hayek concludes, "that the ultimate decisions must be left to the people who are familiar with these circumstances, who know directly of the relevant changes and of the resources immediately available to meet 
them." ${ }^{45}$ His argument against central economic planning, then, is that it is impossible because knowledge cannot be totalized. Total knowledge, complete knowledge, is unobtainable.

Foucault specifies the idea that limits on knowledge are limits on government as the economic rationality of liberalism. Liberalism extends the problem of economic knowledge into a more fundamental incompatibility between "the non-totalizable multiplicity of economic subjects of interest and the totalizing unity of the juridical sovereign." ${ }^{36}$ Insisting that the totality of economic processes cannot be known, liberal economics renders a sovereign view of the economy impossible. In other words, for the liberal, the limit of sovereign knowledge is a limit on sovereign power. As Foucault puts it, homo economicus tells the sovereign, "You must not because you cannot. And you cannot in the sense that 'you are powerless.' And why are you powerless, why can't you? You cannot because you do not know, and you do not know because you cannot know." ${ }^{47}$ Just as the impossibility of complete knowledge served as a wedge against sovereign power, so does the inability to know emerge as an attempt to block or suppress politics, to displace matters of will and action onto questions of knowledge.

Foucault's historical account of the links between the rise of economics as a discipline and the liberal political challenge to absolutism is compelling, particularly as it situates liberal and neoliberal approaches to the market in the context of struggles and debate. He provides a potent reminder of the fact that attempts to limit the power of the sovereign shift over the nineteenth and twentieth centuries from limitations on the sovereignty of the king to limitations on the sovereignty of the people. This shift displaces our attention from the ways law, legitimacy, and sovereign authority have never been fully grounded in knowledge but have to appeal to an addressee capable of responding to and as a collective.

Complexity displaces accountability onto knowledge. In documents that Goldman Sachs made available to the Senate Permanent Subcommittee on Investigations, the firm stated that it "did not have access to any special information that caused [it] to know that the US housing market would collapse." ${ }^{48}$ It explained that its risk management decisions 
were not motivated by any collective view of what would happen next, but rather by fear of the unknown. The firm's risk management processes did not, and could not, provide absolute clarity; they underscored deep uncertainty about evolving conditions in the US residential housing market. That uncertainty dictated our decision to attempt to reduce the firm's overall risk. ${ }^{49}$

It's hard to know what would count as such special information, information that could itself be a cause of knowledge of the future rather than one of its multiple possible contents (perhaps predestination understood as God's foreknowledge would be an example of this kind of information). The Goldman Sachs' report presumes a binary of absolute clarity versus deep uncertainty, of knowledge of what would happen next opposed to fear of the unknown. It's as if Goldman Sachs' defense is that it is not God. It does not have divine knowledge. Lloyd Blankfein's testimony that the firm does God's work suggests that a megalomaniacal sense of its own importance is part of Goldman's corporate culture. Absence of absolute clarity is no excuse, no defense, but it is evidence of an other-worldly selfconcept, an epic sense of power. Only someone who presumes that others think he has absolute knowledge would have to explain that he lacks it.

Some commentators and analysts have blamed the discipline of economics for the financial crisis. One of their arguments turns on one of the discipline's primary assumptions, namely, that economics is a science that can and does know that markets are efficient. The efficient market hypothesis $(\mathrm{EMH})$ is the supposition of an underlying balance or best distribution. It turns on the idea of price, that prices reflect all available relevant information. Because this information is built into a price, what will happen to that price in the future is impossible to predict. If it were possible, the predicted future would already be reflected in the price. ${ }^{50}$ So even though no one agent can know the truth of the economy, even though this truth eludes the sovereign, market equilibrium (as embodied in each price at a given moment) must be presupposed as the sum total of the knowledge of each actor.

The interesting twist here is that if the EMH designates a truth embodied in prices, then it can be measured or, at the very least, modeled with a high degree of assurance. This supposition of the accuracy of economic 
models fueled the calculations of the "quants" or experts in mathematical approaches to finance who played major roles in hedge funds' and investment banks' approaches to risk over the last decades. Their models identify deviations and discrepancies in prices. These discrepancies show up as volatility, where volatility designates movement around an expected price, that is, more or less probable chances. If gas prices are normally between three dollars and three dollars and fifty cents a gallon, prices over four dollars a gallon suggest that something is going on and this something can then be an opportunity to bet or trade. At any rate, the underlying idea here is that contingency in prices admits of predictability. Rather than indexing the incalculable or unknowable, it points to states of affairs with varying degrees of probability. Even if we don't know exactly what will happen at a certain point in time, we do know that some outcomes are more likely than others.

In the wake of the collapse of the subprime mortgage market (and repeating insights ostensibly gained in the wake of similar collapses in recent decades), vocal economists and commentators have reasserted the falsity of the efficient market hypothesis, its untenable premises, and the impossibility of applying it to real existing markets. Blame for the collapse rests on economic models' abstraction from their contexts (for example, the divergence of a statistical approach to mortgages from its setting in a housing bubble amidst rising inequality). A particularly powerful version of the argument comes from Nicholas Taleb's account of black swans, or low likelihood/high impact events capable of setting off chain reactions as they cascade through the markets. ${ }^{51}$ Yet these and similar emphases on unknowability end up resonating with the excuses of bank regulators and executives: they did not know (what was coming); and, they did not know, because they could not know. These accounts, too, get caught up in expectations and bubbles. As Charles Prince, then CEO of Citigroup, said in July 2007, "As long as the music is playing you've got to get up and dance." 52 Activity convergences with passivity. Bankers had no other choice; they could not do otherwise. Consequently, they offer excuses for their inability to act even as they relied, momentarily, on a powerful a sovereign capable of rescuing them.

The back and forth between knowing and not-knowing, the fragmentation of knowledge into information that disperses into networks 
only to be abstracted, aggregated, and amplified and then chaotically dissolved at points of crisis, suggests the utility of analyzing neoliberalism and its vicissitudes in terms of the oscillations of drive. Partial knowledge may be a limitation, but it is more importantly a condition. The partiality and fallibility of knowledge, the complexity of its interconnections, does not excuse inaction. It is the setting of action (and should be understood as its ground). We have to act because we do not know.

\section{Conclusion}

I've argued that reflexivity and complexity are key components of neoliberalism as an ideological formation. Rather than configuring desire, however, they run a circuit of drive, capturing subjects in patterns and loops and practices from which it seems there is no escape. While my focus has been on the more obscene components of speculative finance, I don't want to leave the impression that the work of reflexivity and complexity in contemporary ideology is somehow pre-political or post-political. On the contrary, in our current formation appeals to both support the very, very rich and undermine the rest of us.

First, reflexivity's displacement of politics into narcissistic circuits of self-absorption dominate what passes for political commentary throughout the tumultuous and varied terrain of contemporary media. Bloggers blog and commentators comment on blogs and bloggers comment on commentators. A similar transfer of intensity animates Wall Street as the never-ending pursuit of profit animates efforts to produce, commodify, and bet on risk. The academic version recedes in levels of increasing meta-ness, commenting on discourses and practices and alternatives and limits until the need to act loses its force and urgency. Freud's observation that the objects of the drive can appear in each others' places, accumulating the others' intensity, alerts us to the ways that multiple, minor achievements (more hits on my blog, a higher daily book value) can well be moments in larger circuits of failure and defeat, acquiescence and accommodation. Approaches to risk that highlight possible perverse effects of regulation demonstrate the same logic. The big banks successfully fought against serious regulation of derivatives with the argument that banks would just come up with even more complex and dangerous 
ways to transfer risk from their books and produce new sources of profit. The ostensible reality of reflexivity in markets is that agents will incorporate changes in their setting into the behavior, and so just work around any changes (like water going downhill). We should immediately be suspicious of such an appeal to reality as indicative of what Mark Fisher theorizes as "capitalism realism," the excuse for capitalist excesses offered as if there were no alternative. ${ }^{53} \mathrm{We}$ don't normally let the fact that murders occur convince us that murder should not be criminalized, so we shouldn't let the fact that bankers say they will find ways to work around regulations prevent us from regulating them.

Second, just as reflexivity displaces politics, so does complexity. Invocations of complexity induce us, the people, to think that self-governance is impossible, too hard, over our heads. It's like an excuse for avoiding responsibility, an infantile fantasy that somehow we can escape politics. Global networks, neural networks, financial networks - if it's all just too complex for us to understand we are left off the hook for our abdication of political responsibility (no wonder the education system has been left to rot; no wonder higher education is a major front of political struggle-the more people believe the lie of "too complex to understand," the more they concede). Unfortunately, academics contribute to the ideological effects of complexity. We emphasize that there is always more that needs to be known, that there are unknown unknowns and unintended consequences of whatever it is that we end up doing. Complexity's tagging of the multiplicity of interrelated and unpredictable effects presents us as so deeply enmeshed in our situations that we can't assess them; we can only react, and just in time, in a 24/7 ever faster market.

But notice: at this point, the excuses - we can't predict what will happen, we can't know - turn back in on their reflexive partner: we are compelled to react, not reflect, even as we are enjoined to think more, think more thoroughly, consider all the options. We are pushed in conflicting directions, with full force, told that each is necessary, unavoidable, realistic. These injunctions, impossible to realize, impossible to avoid, signal that the neoliberalism entrapping us is ideology, not necessity. 


\section{Works Cited}

Adams, Thomas and Yves Smith. "FCIC Report Misses Central Issue: Why was there Demand for Bad Mortgage Loans.” Huffington Post (31 January 2011). http:// www.huffingtonpost.com/thomas-adams-and-yves-smith/fcic-report-missescentra_b_816149.html

Arrighi, Giovanni. “The Social and Political Economy of Global Turbulence.” New Left Review 20 (2003): 5-71.

Bennett, Jane. Vibrant Matter. Durham, NC: Duke University Press, 2009.

Berardi, Franco. The Soul at Work. Los Angeles, CA: Semiotext(e), 2009.

Carter, Zach. “Live Blogging the Ratings Agency Hearing.” June 2, 2010. [Formerly http://www.ourfuture.org/blog-entry/2010062202/ liveblogging-rating-agencies-hearing]

Cassidy, John. How Markets Fail. New York: Farrar, Straus, and Giroux, 1999.

Dean, Jodi. Democracy and Other Neoliberal Fantasies. Durham, NC: Duke University Press, 2009.

—. "Drive as the Structure of Biopolitics." Krisis 2 (2010). http://krisis.eu/index en.php - htmlpart=issues.php?issue=2010, Issue 2 .

—. Žižek's Politics. New York: Routledge, 2006.

Fisher, Mark. Capitalist Realism. UK: Zero Books, 2009.

Foucault, Michel. The Birth of Biopolitics. Trans. Graham Burchell. New York: Palgrave Macmillan, 2008.

Fox, Justin. The Myth of the Rational Economy. New York: Harper Business, 2008.

Freud, Sigmund. "Instincts and their Vicissitudes." The Standard Edition of the Complete Psychological Works of Sigmund Freud, Volume XIV (1914-1916): On the History of the Psycho-Analytic Movement, Papers on Metapsychology and Other Works. James Strachey, ed. London: Hogarth Press, 1915.

“Goldman Sachs and the Financial Crisis," The New York Times (24 April 2010), http://documents.nytimes.com/goldman-sachs-internal-emails - document/

Hayek, Friedrich. “The Use of Knowledge in Society.” American Economic Review 35.4 (September 1945): 519-530. http://www.econlib.org/library/Essays/hykKnw1. html

Kapur, Ajay, Niall Macleod, and Narendra Singh. "Revisiting Plutonomy: The Rich Getting Richer.” Citigroup. March 5, 2006. http://sttpml.org/wp-content/ uploads/2013/10/Citigroup_Plutonomy_Report_Part_2.pdf 
Lacan, Jacques. Seminar VII: The Ethics of Psychoanalysis. Jacques-Alain Miller, ed. Trans. Dennis Porter. New York: Norton, 1997.

Lewis, Michael. The Big Short. New York: W. W. Norton and Company, 2010.

LiPuma, Edward and Benjamin Lee. Financial Derivatives and the Globalization of Risk. Durham, NC: Duke University, 2004.

Nicolis, Grégoire and Ilya Prigogine. Exploring Complexity. New York: W. H. Freeman and Company, 1989.

Passavant, Paul A. "Mega-Events, the Superdome, and the Return of the Repressed in New Orleans." The Neoliberal Deluge: Hurricane Katrina, Late Capitalism, and the Remaking of New Orleans. Cedric Johnson, ed. Minneapolis: University of Minnesota Press, 2011.

Patterson, Scott. The Quants. New York: Crown Business, 2010.

Pierson, Paul and Jacob S. Hacker. Winner Take All Politics. New York, Simon and Schuster, 2010.

Soros, George. The Crash of 2008 and What It Means. New York: Public Affairs, 2008.

Taleb, Nicholas. The Black Swan. New York: Random House, 2007.

Taylor, Mark C. Confidence Games. Chicago: University of Chicago Press, 2004.

Waldrop, M. Mitchell. Complexity: The Emerging Science at the Edge of Order and Chaos. New York: Simon and Schuster, 1992.

"What the trader said: 'in the middle of complex trades without understanding them.” The Independent (26 April 2010). http://www.independent.co.uk/news/ business/news/what-the-trader-said-in-the-middle-of-complex-trades-withoutunderstanding-them-1954288.html

Žižek, Slavoj. In Defense of Lost Causes. London, Verso: 2008.

—. The Parallax View. Cambridge, MA: The MIT Press, 2006.

—. The Ticklish Subject. London: Verso, 1999.

\section{Notes}

1. For a more thorough discussion of neoliberalism see, Jodi Dean, Democracy and Other Neoliberal Fantasies (Durham, NC: Duke University Press, 2009).

2. See Slavoj Žižek, The Ticklish Subject (London: Verso, 1999). 
3. For example, see M. Mitchell Waldrop, Complexity: The Emerging Science at the Edge of Order and Chaos (New York: Simon and Schuster, 1992) and Grégoire Nicolis and Ilya Prigogine, Exploring Complexity (New York: W. H. Freeman and Company, 1989).

4. For a more thorough account of Žižek's approach to ideology, see Jodi Dean, Žižek's Politics (New York: Routledge, 2006).

5. Slavoj Žižek, In Defense of Lost Causes (London, Verso: 2008), p. 328

6. Slavoj Žižek, The Parallax View (Cambridge, MA: The MIT Press, 2006), p. 61.

7. Sigmund Freud, "Instincts and their Vicissitudes," The Standard Edition of the Complete Psychological Works of Sigmund Freud, Volume XIV (1914-1916): On the History of the Psycho-Analytic Movement, Papers on Metapsychology and Other Works, James Strachey, ed. (London: Hogarth Press, 1915), p. 126.

8. Quoted in Jacques Lacan, Seminar VII: The Ethics of Psychoanalysis, JacquesAlain Miller, ed., Trans. Dennis Porter (New York: Norton, 1997), p. 71.

9. Jacques Lacan, Seminar VII, p. 212.

10. Mark C. Taylor, Confidence Games (Chicago: University of Chicago Press, 2004), p. 285.

11. George Soros, The Crash of 2008 and What It Means (New York: Public Affairs, 2008), p. 8, 10.

12. Justin Fox, The Myth of the Rational Economy (New York: Harper Business, 2008), p. 238; John Cassidy, How Markets Fail (New York: Farrar, Straus, and Giroux, 1999), p. 274-275.

13. Basel II accords let this self-determining standard suffice for international banking.

14. Justin Fox, The Myth of the Rational Economy, p. 238.

15. Scott Patterson, The Quants (New York: Crown Business, 2010), p. 53.

16. Justin Fox, The Myth of the Rational Economy, p. xii; Edward LiPuma and Benjamin Lee, Financial Derivatives and the Globalization of Risk (Durham, NC: Duke University, 2004), p. 35.

17. Edward LiPuma and Benjamin Lee, Financial Derivatives and the Globalization of Risk, p. 34.

18. Justin Fox, The Myth of the Rational Economy, p. xii.

19. Edward LiPuma and Benjamin Lee, Financial Derivatives and the Globalization of Risk, p. 108: "A critical dimension of derivatives is that they do not involve the immediate exchange of principal and, accordingly, are not immediately counted on financial balance sheets, so that especially when financial agents 
combine different types of derivatives they allow for an extraordinary and unprecedented degree of leverage."

20. Scott Patterson, The Quants, p. 190.

21. Edward LiPuma and Benjamin Lee, Financial Derivatives and the Globalization of Risk, p. 105.

22. Ibid., p. 118.

23. Michael Lewis, The Big Short (New York: W. W. Norton and Company, 2010), p. 77-78.

24. Thomas Adams and Yves Smith, "FCIC Report Misses Central Issue: Why was there Demand for Bad Mortgage Loans," Huffington Post (31 January 2011). http://www.huffingtonpost.com/thomas-adams-and-yves-smith/fcicreport-misses-centra_b_816149.html

25. See Giovanni Arrighi, "The Social and Political Economy of Global Turbulence,” New Left Review 20 (2003): 5-71. On US as debtor: p. 70.

26. For a detailed discussion, see Paul Pierson and Jacob S. Hacker, Winner Take All Politics (New York, Simon and Schuster, 2010).

27. Michael Lewis, The Big Short, p. 179.

28. Scott Patterson, The Quants, p. 197.

29. Michael Lewis, The Big Short, p. 77.

30. I don't refer here to specific US policies to enable low income people to purchase homes because housing bubbles occurred in 11 different countries during the period of the US bubbles. See George Soros, The Crash of 2008 and What it Means, p. 84, noting bubbles in the UK, Spain, and Australia.

31. Scott Patterson, The Quants, p. 194.

32. Michael Lewis, The Big Short, p. 54: "In the second quarter of 2005, credit card delinquencies hit an all-time high-even though house prices had boomed. That is, even with this asset to borrow against, Americans were struggling more than ever to meet their obligations. The Federal Reserve had raised interest rates, but mortgage rates were still effectiviely fallingbecause Wall Street was finding ever more clever ways to enable people to borrow money."

33. Ibid., p. 151.

34. Ibid., p. 165.

35. Michel Foucault, The Birth of Biopolitics, Trans. Graham Burchell (New York: Palgrave Macmillan, 2008). 
36. For a more thorough discussion, see Jodi Dean, "Drive as the Structure of Biopolitics,” Krisis 2 (2010). http://krisis.eu/index_en.php - htmlpart=issues. php?issue $=2010$, Issue 2

37. Ajay Kapur, Niall Macleod, and Narendra Singh, "Revisiting Plutonomy: The Rich Getting Richer," Citigroup. March 5, 2006. http://sttpml.org/wpcontent/uploads/2013/10/Citigroup_Plutonomy_Report_Part_2.pdf

38. Michael Lewis, The Big Short, p. 131.

39. Email extracts available at "What the trader said: 'in the middle of complex trades without understanding them,"” The Independent (26 April 2010). http:// www.independent.co.uk/news/business/news/what-the-trader-said-in-themiddle-of-complex-trades-without-understanding-them-1954288.html

40. Zach Carter, “Live Blogging the Ratings Agency Hearing,” June 2, 2010. [Formerly http://www.ourfuture.org/blog-entry/2010062202/ liveblogging-rating-agencies-hearing]

41. Jane Bennett, Vibrant Matter (Durham, NC: Duke University Press, 2009), p. 25.

42. Jane Bennett, Vibrant Matter, p. 38.

43. See Paul A. Passavant, "Mega-Events, the Superdome, and the Return of the Repressed in New Orleans," The Neoliberal Deluge: Hurricane Katrina, Late Capitalism, and the Remaking of New Orleans, Cedric Johnson, ed. (Minneapolis: University of Minnesota Press, 2011), p. 87-129.

44. Franco Berardi, The Soul at Work (Los Angeles, CA: Semiotext(e), 2009), p. 211. The sentence continues "and of the incompatibility or unfitness of the general intellect when confronted with the framework of capitalist governance and private property." I am not disagreeing here with the claim that there is an incompatibility between the general intellect and the capitalist system (although I would want to emphasize the antagonism disrupting, constituting, and imbricating both). Rather, my point here is that it is precisely the antagonism that should be emphasized, not complexity.

45. Friedrich Hayek, "The Use of Knowledge in Society,” American Economic Review 35.4 (September 1945): 519-530. http://www.econlib.org/library/ Essays/hykKnw1.html

46. Michel Foucault, The Birth of Biopolitics, p. 282.

47. Ibid., p. 283.

48. "Goldman Sachs and the Financial Crisis," The New York Times (24 April 2010), p. 11. http://documents.nytimes.com/goldman-sachs-internal-emails - document/

49. “Goldman Sachs and the Financial Crisis,” p. 12. 
50. Scott Patterson, The Quants, p. 82.

51. Nicholas Taleb, The Black Swan (New York: Random House, 2007).

52. Quoted in John Cassidy, How Markets Fail, p. 296.

53. Mark Fisher, Capitalist Realism (UK: Zero Books, 2009). 
Chapter 7

\title{
Neoliberalism, Risk, and Uncertainty in the Video Game
}

\author{
ANDREW BAERG
}

This essay deploys and brings governmentality theory to bear on the question of neoliberalism and its expression in the video game. Neoliberalism's naturalization of the free market and the extension of its principles into non-economic phenomena have left neoliberal subjects responsible for their own well-being and the decisions that need to be made to ensure this well-being. Neoliberalism not only establishes the conditions of this responsibility, but also shapes how this responsibility is to be manifested as subjects deal with the risks attached to freedom.

This paper discusses the relationship between governmentality theory, neoliberalism and risk before exploring how the contemporary video game naturalizes a neoliberal decision-making process that is increasingly characterized by an approach grounded in risk and risk management. Given the popularity of the contemporary video game, this essay demonstrates how neoliberal discourses oriented around risk express themselves in leisure spaces and position subjects to approach decisions in a specifically neoliberal manner with respect to risk. Given the essay's focus on the video game itself, it does not account for how users respond to or take up these neoliberal ideas in practice. After all, video games exist as possibility spaces in which users actualize these possibilities through a game's respective rules. ${ }^{1}$ How these choices in the medium shape their choices outside the medium goes beyond the scope of this essay. This project's narrower concentration on the video game itself argues that it functions as a technology of neoliberal government, one component 
within a broader assemblage of forces by which governing authorities instantiate desired conduct. ${ }^{2}$ With the paper's closer focus on desired conduct and its relation to risk, it extends prior work linking neoliberalism to the digital game. ${ }^{3}$

\section{Governmentality, Neoliberalism, Risk}

One of the ways in which scholars have approached neoliberalism and risk has been through governmentality theory. Foucault defines governmentality as "the way in which one conducts the conduct of men." This definition is echoed by others who have followed Foucault in theorizing about government. ${ }^{5}$ Governmentality theory not only focuses on government writ large, but on micro-processes of government as well. Governmentality bridges the analysis of a broader biopolitics of governing the conduct of populations to that of the anatomo-politics of the governing of individuals and selves and their conduct. ${ }^{6}$ As such, governmentality examines how power flows function apart from the State and considers governing practices. ${ }^{7}$ Those who have used governmentality theory to address present social and political conditions have concentrated on a relatively recent iteration of government, advanced liberal or neoliberal governmentality.

Those subscribing to governmentality theory explain neoliberalism by grounding it in an older liberalism and this liberalism's accompanying preoccupation with the free market. In his examination of the eighteenth century roots of neoliberal governmentality, Foucault ${ }^{8}$ argues that the market became the guiding metaphor for liberal governing. The market was understood to obey natural laws, laws that expressed themselves in prices that rose and fell with supply and demand. In order for these natural laws to play themselves out, those operating within the market were to be given as much freedom as possible. This market freedom was extended to an evaluation of governmental practice such that the free market became the basis for the formation of a governmentality stressing freedom. Government was no longer to impose power, but to manage freedom. The free market economy and liberal state ended up reciprocally supporting one another in their commitment to managing freedom. 
These principles of eighteenth century liberalism find a renewal in twentieth century neoliberalism. With the advanced liberal or neoliberal rationalities of government prominent in the late twentieth and early twenty-first century, the power of government finds justification in "artificially arranged or contrived forms of the free, entrepreneurial and competitive conduct of economic-rational individuals." In this context, the governed, free, neoliberal subject becomes what Foucault variously calls homo economicus, "an active economic subject"10 and an entrepreneur of the self. The economic subject must think about the self and others as engaged in competition where choices must be made about scarce resources. Notions of supply and demand and investment-costs-profit become the way the individual relates to the self and then outward. The entrepreneurial self is invited to employ "certain management, economic, and actuarial techniques" ${ }^{11}$ in everyday practice. As such, in neoliberalism, the market is applied to traditionally non-economic social phenomena such that subjects consistently operate through this entrepreneurial lens and employ its techniques in their conduct. ${ }^{12}$

\section{Neoliberalism and Risk}

To function as an entrepreneurial self is to necessarily consider one's future. How this future is understood and how decisions are made about this future take on particular contours within neoliberalism. Given the neoliberal subject's freedom to function as an entrepreneurial self, they are simultaneously responsible for dealing with the risks of potential dangers and misfortune attached to this freedom as well. How is risk understood within the framework of a neoliberal governmentality?

Governmentality theorists have argued that risk can be understood as a governmental rationality, a particular way of thinking about and responding to governmental problematics. These rationalities render reality in a particular way so that governing may occur. ${ }^{13}$ Rendering reality in terms of risk serves as an expression of a specific governmental rationality tied to governing the future. Risk management becomes the rational response to risk for its "identification, assessment, elimination or reduction of the possibility of incurring misfortune or loss." ${ }^{14}$ Assessing and managing risk engages a precarious future. O'Malley affirms the 
future orientation of risk in arguing that risk produces "the state to be avoided, the state to be achieved, and the acceptability of ways whereby the two conditions should be governed." ${ }^{15}$ Within neoliberal approaches to these future conditions, risk and risk management take on a specific shape characterized by an emphasis on individualism, a privileging of a scientific, actuarial matrix of expertise and its accompanying bias toward a quantitative epistemology.

First, in neoliberalism, risk is predominantly an individual matter. If the neoliberal self is an entrepreneurial self, then this self must necessarily be induced to adopt a particularly individualistic rationality with respect to risk. The entrepreneurial self's more individualized approach to risk contrasts older approaches to risk in the more collectivist welfare state. As Rose points out, risk used to be understood as social. ${ }^{16}$ Early forms of statistical reasoning in nineteenth century France and Italy were deployed in the service of dealing with collective risks attached to public security and public health. ${ }^{17}$ In the nineteenth century, establishing security over and against various forms of risk meant becoming part of social organizations like trade associations and, at a broader more compulsory level, national social insurance programs. Risk was collectivized within these types of social structures. ${ }^{18}$

However, in neoliberalism, this collective approach to risk has been challenged under the pressure of free markets that require individuals to be responsible for their own well-being. As an example, social insurance programs have come to be understood to foster a culture of dependence and laziness. Neoliberal subjects are encouraged to consider their individual futures rather than depend on social entities for what is to come. Lazzarato goes so far as to argue that neoliberal subjects exist in a context permeated by "permanent insecurity and precarity." ${ }^{19}$ As a consequence of subjects being left free to address the promise and peril of their respective futures, entrepreneurial selves are positioned to adopt a rationality of risk and risk management. Subjects begin to operate in a context characterized by, what O’Malley calls "prudentialism." ${ }^{20}$ This prudentialism places the responsibility for managing risk on the individual who can no longer rely on larger social collectives to deal with risk. Risk and techniques for managing risk become privatized and individuals are encouraged to govern themselves responsibly in addressing risk, i.e. to act with 
prudence. The rational individual practices a rationality of risk management in order to act prudentially and successfully deal with risk.

A second aspect of the relation between neoliberalism and risk concerns a privileging of what might be deemed a scientific, actuarial matrix of expertise. Although the entrepreneurial self is incited to take responsibility for risk without relying on a broader collectivity, neoliberalism makes particular forms of expertise readily available. Entrepreneurial selves are invited to take advantage of this expertise as a way to be responsible and this expertise becomes one of the ways by which responsibility is understood. Governmentality theorists have suggested that expertise serves as one of the primary ways in which governmental objectives are translated into everyday experience. Experts assert truth claims and dispense pedagogical resources as a way to incite individuals to act in keeping with governmental objectives. For example, experts might teach subjects how to achieve greater earning capacity or improved health. Expertise makes government possible and legitimizes it by mediating governmental objectives such that "self regulatory techniques can be installed in citizens that will align their personal choices with the ends of government." 1

In most cases, the power to define what constitutes risk and how it ought to be addressed is held by those with social power. In neoliberalism, experts who were once respected and subsequently possessed relative autonomy in the welfare state have their expert knowledge critiqued. ${ }^{22}$ With respect to risk, older forms of expertise become substituted for a scientific, actuarial matrix of expertise.

Although Beck does not subscribe to governmentality theory, his discussion of scientific expertise and its relation to risk is helpful here. Beck asserts that, in the context of risk, one of the foremost sites where this social power is expressed is the scientific community. ${ }^{23}$ For him, risk has come to only be detected in the contemporary situation through the extended senses of the scientific. Scientific senses render risk visible. Beck goes so far as to say that if a risk cannot be scientifically recognized, then it ostensibly does not exist. Science has the social power to dictate what constitutes risk and how the public perceives these risks. Scientists serve as the experts whose expertise is incontrovertible. Proof of risk's 
existence and what constitutes and causes risk become the purview of these scientific experts.

In the overwhelming majority of instances, the sciences employ quantitative methods to render risk visible. This methodology assumes that "scientific methods of measurement and calculation are the most appropriate way to approach risks descriptively, explanatorily and prognostically, and importantly, also politically." ${ }^{24}$ With this emphasis on the calculative approach to risk, Beck echoes Foucault's discussion of a more specific kind of scientific gaze, the medical gaze on the body, a quantifying gaze that made "it possible to outline chances and risks; it was calculating." ${ }^{25}$ These quantitative methods applied to risk sit at the core of a specific type of science, actuarial science. Actuarial science is expressed in practice through actuarialism. This actuarialism can be characterized by an emphasis on non-invasive forms of routine surveillance, a greater and greater speed in the acquisition of information for the purpose of managing populations, an approach to risk that is heavily based in statistical knowledge, a morality that is grounded in statistical norms and a production of risk that engenders increasing numbers of risks. ${ }^{26}$ Actuarial science produces mountains of quantitative data as a way to manage the risks that it continuously produces and makes intelligible.

Because science and actuarial science make risk visible and perpetuate risk, they bring along an attendant epistemological assumption that perceives risk through a causal frame. Beck argues that,

in order to recognize risks at all and make them the reference point of one's own thought and action, it is necessary on principle that invisible causality relationships between objectively, temporally, and spatially very divergent conditions, as well as more or less speculative projections, be believed. ${ }^{27}$

As the expertise of science presents these cause-effect relations with respect to risk and persuades individuals to believe in these relations, this causal perspective necessarily fosters a zone of responsibility for those subject to these discourses. If risks are grounded in causes, then responsible interventions can occur before deleterious effects ensue. For subjects to refuse to perceive risk through this causal lens is to be irresponsible. For Beck, ${ }^{28}$ ordinary citizens are not allowed to question 
these assumptions or to redefine these questions surrounding risk for themselves. They must adopt this causal approach to risk and subsequently practice responsibility for managing risk according to the definitions offered them by said experts. As non-experts with more limited knowledge, they have responsibility foisted upon them in the midst of myriad variables.

As part of this shift from older forms of expertise toward a neoliberally-inflected, scientific, actuarial expertise, a broader commercial culture of risk arises. The risk industry and various professions linked to minimizing, managing and preventing risk feed concerns about risk by creating and marketing various products that presumably allow us control over our own fates. ${ }^{29}$ The rationality fostered by the risk industry generates "a relentless imperative of risk management not simply in relation to contracting for insurance, but also through daily lifestyle management, choices of where to live and shop, what to eat and drink, stress management and exercise...." 30 The risk industry not only touches the outer person, but the inner person as well as it capitalizes on risk management techniques linked to self-esteem and empowerment. The risk industry encourages subjects to take responsibility for themselves by operating within the parameters of efficiency and cost-benefit analysis as a way to incite them to a semblance of agency.

The neoliberal culture of risk becomes amplified and exacerbated such that few areas of life remain untouched by its perpetuation of a risk management rationality. Personal choices come to be increasingly oriented around risk, a risk that is defined by scientific, actuarial expertise and mediated through the risk industry. Risk experts functioning within the risk industry adopt an incontrovertible monopoly on risk assessment and governance as they incite individuals to responsible action. ${ }^{31}$

As the scientific, actuarial matrix of expertise operates in the cultivation of responsibility, it works in and through a third element of neoliberalism's relation to risk, technologies of government. Risk and techniques for risk management are produced by and mediated through technologies of government. In governmentality theory, technologies of government do not necessarily function as direct connections from governmental authority to individuals and groups. Rather, they exist as part of what Rose and Miller perceive as "the complex assemblage of diverse forces" 
that operate to instantiate the interests of government in those who make decisions. ${ }^{32}$ Technologies of government play an important role in realizing governmental thought. ${ }^{33}$ They serve as the various ways in which individual conduct, thinking, and goals are shaped and normalized for the purpose of governmental goals. ${ }^{34}$ These technologies may be more formal with respect to forces circulating around law and finance or they may be "humble and mundane" 35 in operating through the everyday mechanisms of things like calculations, surveys and speech communities. ${ }^{36}$ Technologies of government are not essentially linked to specific forms of governmentality. Rather, technologies only become important in their relation to ideas and practices as certain manifestations of governmentality facilitate and pattern these various practices within their respective techno-social relations. ${ }^{37}$ What is significant for this discussion is "how a given technology or space is combined, at a particular point in time, with various discourses, political and ethical ideals and already established habits to form a loose assemblage of governmental agency." ${ }^{38}$ Technologies of government become one component within a broader governmentality.

Following from the discussion above, an important part of engaging risk and managing risk in neoliberalism revolves around technologies of government linked to quantitative or calculative rationality. Entrepreneurial selves operating in a neoliberal context function as, "riskassessors, performing the felicity calculus in an attempt to plot the probable and possible consequences of their actions." ${ }^{39}$ Quantifying technologies of government allow these selves to determine what is in their best interests in the present and for the future.

Greater reliance on quantification has led to an increasing consciousness of risk. ${ }^{40}$ As alluded to above, in their deployment within science and actuarial science, numbers play a vital role in producing risk and dealing with risk within liberal and neoliberal government. They enable certain knowledges and the decision-making processes that follow from these knowledges. Subsequently, numbers both constitute risk and become the basis for managing risk. Numbers are also important for the communication of risk. With their ability to momentarily stabilize various dynamic processes, numbers allow for a consideration of probability. Probabilities invariably connect to assessing various degrees of risk. This 
kind of thinking renders risk both visible and calculable in the present. Risk becomes "disciplined, by means of the statistical intelligibility that the collective laws of large numbers seemed to provide." ${ }^{41}$

Numbers typically inform risk assessments. These risk assessments become pedagogical tools that not only teach the entrepreneurial self which decisions to make, but how to think about decision-making. This how is often linked to quantification such that risk assessments further what might also be understood as an audit rationality. The audit rationality subsequently becomes an important way that entrepreneurial selves govern themselves. To practice auditing and to be made auditable is part and parcel of functioning within spaces of risk management. ${ }^{42}$ Numbers also begin to shape the type and nature of choices afforded the entrepreneurial self. Under the influence of the economic freedom of neoliberalism, choice is rendered calculable as subjects attempt to rationalize and optimize their activity. ${ }^{43}$ These choices are presented against a backdrop of risk that is itself buttressed by quantification. Numbers subsequently further the subject who can be "rendered calculable to others and to himor herself in terms of numbers." ${ }^{44}$ Numbers transform individuals into calculating selves who subsequently calculate, predict and evaluate their own actions and the actions of others, especially within the context of risk. As such, numbers come to govern individual behavior. ${ }^{45}$

To combine the ideas of neoliberalism and the free entrepreneurial self, that self's relation to scientific, actuarial expertise and technologies of government that further shape this self's relation to risk is to see the pervasive nature of risk in a neoliberal context. Within this context, Rose sees the risk industry generating a constant stream of imperatives inciting subjects to carefully manage risk in multiple social domains. ${ }^{46}$ This risk industry might be comprised of insurance, security and self-help businesses. However, discourses of risk also find themselves into leisure space as well. In the remainder of this essay, I explore the video game, as one "humble and mundane" site within which risk and risk management are expressed as the right way to attempt to govern an unknown future. ${ }^{47}$ The essay takes up how the technology of the video game combines with neoliberal discourses on risk to serve as one component of a broader, loose assemblage of neoliberal governmental agency. 


\section{Quantification and Risk in the Video Game}

Of specific interest to me in this paper are questions addressing how risk and risk management are made intelligible through the technology of the video game. It would be an exaggeration to argue that all video games invoke a specifically neoliberal approach to video games. However, many popular video game genres including the music, real time and turn-based strategy, first person shooter, and role playing game genres can be more deeply understood through this neoliberal lens. In order to illustrate how a neoliberal rationality of risk expresses itself concretely, I turn specifically to another genre where this rationality appears, the sports video game genre. More particularly, the remainder of this essay looks at one example by analyzing SI Games' popular soccer management simulation, Football Manager 2010 $0^{48}$ (hereafter FM10), from a critical perspective. Although FM10 certainly cannot represent the diversity of video games, many of the game mechanics discussed below can be applied to other sports games and games in other genres.

In FM10, the game's users are not merely football managers, but are simultaneously positioned as entrepreneurial selves who must manage risk. Users must function as entrepreneurial selves by managing risk by deploying various scarce resources to move the club along the road to success and by locating important relationships between causes and effects. However, not only are users risk managers, but the game also positions them as subjects of risk. Users must accomplish these objectives even as they are subject to risk in being under constant surveillance from the club's virtual supporters and chairman. The game subsequently naturalizes an existence as a neoliberal entrepreneurial self who must deal with risk while simultaneously being subject to risk.

\section{Users as Risk Managers}

First and foremost, users are positioned as risk managers. In order to achieve the game's goals of winning championships and in some cases, generating virtual revenue, users must analyze the quantified attributes and performances of virtual athletes to assess present game events and plan future in-game choices. As such, the user becomes aligned with a 
particular approach to risk management characterized by an engagement with numbers at nearly every turn.

\section{Statistical Productivity}

The way that FM10 mediates game information mirrors other forms of new media in the sports media complex that provide quantitative indices measuring typical categories linked to either a given athlete's bodily characteristics or production. ${ }^{49}$ Professional teams will often evaluate potential additions to their squads based on heights, weights, and speed or on previous statistical performance in another context. FM10 gives users access to these kinds of measurements in full force. Every player's profile screen features his height, weight, age, wages and estimated value. In addition, FM10's game engine quantifies myriad statistics that track the productivity of individual players as it simulates matches. Among these statistics include game appearances, goals, assists, man of the match awards, yellow and red cards, tackles succeeded and attempted per game, key tackles, passes completed and attempted, pass completion percentage, key passes, intercepted passes, runs into space, number of times caught offsides, dribbles per game, shots on target percentage, fouls, fouls against, penalties taken and scored, average minutes per goal, minutes since last goal, headers won and attempted, key headers, total distance covered and distance covered per ninety minutes, mistakes leading to goals and total mistakes, and condition percentage. The game engine uses these numbers in a given match to come up with a match rating. These match ratings are then aggregated and averaged to provide the user a sense of that player's performance over the course of a given season. Alongside the average rating, users can find out a player's lowest and highest ratings of the season.

As users play a match, the game continues tracking all of these statistics and makes them readily available at the click of a mouse button. It is entirely possible to play the game like a real world manager by watching the action unfold over the course of ninety real world minutes. Users can literally watch their players move, shoot and pass in a 3D representation of the match. Much like real world managers, users can simply observe how their players perform and adjust their tactics accordingly. If a user 
notices shots flying past the post on a consistent basis, that striker might become a prime candidate for a substitution. If a user sees a midfielder aggressively committing too many fouls, that player's instructions can be modified to make him more cautious. Playing the game this way entails observing the action on the pitch and responding accordingly. However, for users to play a whole season this way would be incredibly time consuming and potentially test any user's patience.

Choosing to play FM10 in this pedestrian, real world style ostensibly deviates from the implied intention of the game's design. FM10's football universe includes 117 leagues yielding a massive number of clubs for users to potentially manage. The manageable teams range all the way from the globally popular such as Spain's, Real Madrid, to the regionally obscure like Singapore's, Balestier Khalsa FC. FM10 allows for the possibility that a team from, for example, one of the English league structure's semi-pro divisions could one day compete in the same division against Premier League giants, Manchester United and Chelsea. Although Sports Interactive allows users to manage the world's biggest clubs, the company actively encourages the fantasies of supporters of lower division clubs. FM10's official website features a discussion forum section dedicated to so-called lower league managers who can share strategies and another sub-section for stories from these managers who have taken their clubs from virtual local obscurity to the heights of glory in world football. The existence of this dedicated forum area suggests the developers' desire to see users achieve successes that would be near impossible in the real world. One of the obstacles to this success might be the time investment required if users played each match in real time. To adopt this approach and make the shift from the sixth tier of English football in the Blue Square South to the top tier of the Premier League would require users to play at least 222 games (not including exhibition and cup games) and work through five seasons of play. For users to achieve this goal by managing matches in real time would mean nearly 20,000 minutes or upwards of 333 hours playing the game. Putting in this time is certainly possible, but highly unlikely, for the overwhelming majority of users. It would also make users' rags-to-riches experiences, experiences that serve as official and unofficial marketing material, extremely rare given the time investment required. 
SI has dealt with this time issue by allowing users the chance to quickly simulate a large portion of the match. Users have the option of managing a match, but limiting what they see in the 3D representation to only goals or only key highlights (free and corner kicks, important tackles, excellent saves, yellow and red cards, narrowly missed shots on goal and the goals themselves). Restricting the visual representation of events in each match dramatically reduces the time users need to complete it. Rather than requiring ninety minutes in real time, matches can now be finished in five or ten minutes of real time. The sharply accelerated clock has some consequences for how the user's experience unfolds. With the match's virtual minutes flying by, users are unable to see what their players are doing outside of these key highlights. Accelerating the clock means skipping over events the game does not deem highlight worthy.

In order to make the unseen visible as and help users discern what is happening between these visually represented highlights, FM10 constantly tracks the aforementioned statistics and provides users access to these numbers. Users see what cannot be seen by looking at the data the game produces. As a result, the game positions users to consistently be accessing quantitative data as a way to gauge how well their team and individual players are performing. Users must attend to team performance statistics like what percentage of time the team possesses the ball and/or how often they have possession in a given area of the field, overall pass completion percentage and how many long shots have been taken. Users must also carefully examine individual statistics as well. These statistics provide greater insight into specific player performances in a given match. In addition, users also see a percentage measuring a player's physical condition. The percentage slowly falls throughout the match to reflect a player's level of fatigue or suddenly drops to indicate a short term or potentially long term injury. Consequently, the numbers mediate events that, due to a user's time constraints, cannot be experienced personally in keeping with how numbers function at a more general level..$^{50}$

Even though users might not be able to witness various forms of potential misfortune and loss to their teams or their players directly, the numbers the game generates renders these dangers visible and amenable to intervention. In this respect, the computer becomes the virtual quasi-scientific, actuarial expert producing the data users can employ 
to make decisions. As users engage this data, they invariably perceive potential threats to their teams in accordance with the risks produced by the computer.

The highly quantified nature of the match experience furthers the instantiation of a neoliberal approach to decision-making. By presenting users with an avalanche of numbers, FM10 positions them to function as entrepreneurial selves who must manage risk by making constant assessments of the data being presented to them. Invariably, this data represents the existence of threats or potential threats to the user's team. Users are positioned to engage this data for the causes of the effects that are the game events. Users may not be able to see their central midfielder successfully breaking up opposition attacks with skillful tackles, but the data allows them to make this conclusion. Users may not be able to see their club being overwhelmed by the percentage of an opposition's possession, but the displayed percentage that has been calculated by the simulation can move the user to switch to a counter-attacking strategy to absorb the pressure. Users may not see their team's lack of success in the attacking zone, but they can look at the shot count breakdown and instruct their players to work the ball into the penalty area rather than have them take longer shots from distance. By checking on scores in other matches, users might instruct the squad to adopt a more attacking or conservative mentality. These statistics become the causes for making tactical changes to the team's playing style or formation that potentially yield the desired effects of victory.

Potential risks also operate on an individual player level as well. Users may check the data to see how many fouls a given defender might be committing and instruct that player to defend more cautiously. Conversely, taking advantage of a poor opposing defender might mean asking a winger or a forward to run with the ball more often in hopes of drawing more fouls and potential yellow or red cards. Examining how many shots on goal a given striker may have successfully put on target could mean the difference between leaving him in the game or inserting a substitute. One of the most important numbers users engage in a match is the conditioning percentage. As a player's conditioning percentage drops throughout a match, he becomes less effective. For users to fail to respond with a substitution could mean tired players committing costly mental errors 
or slightly injured players turning a minor knock into something much more serious. All of these risks come together in the potential for a loss, a downward step on the league table and the potential threat of a lost virtual job.

\section{Quantifying the Body}

Although some exceptions exist, like the aforementioned player condition percentage, the statistical tracking that occurs during matches in FM10 mirrors other types of quantitative representation in media across the sports media complex. By tracking the production of an athlete's labor, FM10 generates data that looks very similar to that which can be found on websites and on television broadcasts. However, differentiating FM10 from other forms of measurement in these media is the game's preoccupation with quantification beyond a given player's direct on-field productivity. Where the conventional statistical categories still mediate a player's labor production and overall contribution to a squad's success or failure, FM10 quantifies variables that have no real world correlation. To quantify that which really cannot be truly quantified is to place a grid of intelligibility over the seemingly immeasurable and position it within the parameters of risk management to an even greater degree. The user as entrepreneurial self must navigate the risks of decisions grounded in the quantification of intangibles linked to the athletic body and its potential.

With respect to individual players, each of the more than 297,000 football players in the database is represented by a series of attributes that mediate that player's physical composition and talent. Again, the computer as expert provides this data to the user. The attributes for each player are divided into three categories: mental, physical and technical. First, mental attributes represent a player's ability to think on the pitch and provide a rudimentary psychological profile. Players with high mental attributes will continue to give their maximum effort no matter whether the team is favored to take an easy victory or facing near impossible odds. Mental attributes also indicate how players read and react to situations as the match unfolds. These attributes include variables like anticipation, creativity, determination, positioning and work rate. Second, a player's physical attributes represent his body's ability to move. 
Physical attributes include acceleration, jumping, natural fitness, and strength. The game's manual suggests that physical attributes are most important stating that if a player has sound physical attributes, "he'll be able to play a competent game and make sure he isn't embarrassed much" and that "he has the required attributes to be a solid footballer." ${ }^{1}$ Third, technical attributes most directly represent what might be approximated as a player's 'acquired' football skills. Technical attributes include dribbling, free kick taking, passing and tackling. The manual states that high technical attributes differentiate the best players from the above average and average players. Elite players will always possess high ratings in technical attributes. The cumulative effect of these attribute categories means that every player in the database is assigned a rating of 1-20 for each of the game's forty-two player attributes. These attributes also combine with the level of competition in the player's league to provide him with a valuation. This valuation becomes a guide outlining roughly how much a team would have to pay to acquire his services. In order to understand how their chosen club is performing, users must engage these different attributes and their relationship to the attributes of opposing teams.

The sum total of the way these numbers constitute the reality of the game world constructs the athlete as what Rose calls a "calculable other." 52 This calculable other becomes a scarce resource users deploy in the game. The real world athlete becomes subject to the ratings systems in place in digital sports games; the user engages with that athlete almost entirely on the basis of that athlete's enumerative representation. To look at the individual player profile screen and its quantification of the athletic body is to see a bridge between a scientific cause-effect approach to risk and governmentality theory's connection between the market and an entrepreneurial approach to risk. By quantifying the player into a series of respective attributes, the athletic body become subject to the purview of the scientific, actuarial gaze as its component parts are dissected and made available for scrutiny. As stated above, for users to ignore these attributes would be to fail to adequately assess potential causes for the effects that ensue during matches.

In order to play the game in a responsible way, the user must engage the game world in the same way that Foucault ${ }^{53}$ describes how liberal governments engaged those they managed. In both instances, statistics 
allow for surveillance, analysis and intervention into the lives of populations. Respective virtual and material individual bodies became subject to the statistical such that numbers became the basis for distinguishing between "the more or less utilizable, more or less amenable to profitable investment, those with greater or less prospects of survival, death, and illness, and with more or less capacity for being carefully trained." ${ }^{44}$ To assess whether a given player is more or less utilizable, a sound investment, has a better chance of thriving on one's squad, whether he is heading towards the end of his career, might be prone to injury or has the potential to be managed successfully is to function as an entrepreneurial self. The virtual athletic body becomes a potentiality from which the user must maximize to extract the greatest value. To look at the different attributes of various players is to be able to compare them through the numbers the game provides. Given that the player serves as a resource, and a scarce resource when it comes to the game's best players, the user is positioned to act as an entrepreneur who must responsibly deploy this resource for a set of desirable ends.

In FM10, the entrepreneurial self who is the user is positioned to deploy quantitative data to make risk-based decisions that not only potentially yield success, but also guard against loss and failure. As a result, turning athletes into calculable others renders them subject to risk and risk management practices through the mediation of their respective abilities in the number. For users to fail to perceive the importance of these numbers is to fail to play the game responsibly. Invariably, ignoring player performance on the pitch or the players' respective attributes off of it will mean being fired from one's managerial position and potentially without an ability to continue playing the game.

\section{User as Subject to Risk}

Not only does FM10 position users as risk managers, but users themselves become subject to risk management. Given their place as managers functioning between the virtual playing staff and virtual boardroom, users are responsible to the authorities above them who have the ability to continue to allow them to manage the squad or to dismiss them from their managerial position. 
In FM10, individual players, teams and club finances quantified for careful risk management. However, the user's alter ego is also quantified as well. Users can examine their manager's profile for information about their existing contract, the virtual wages they are earning and their general knowledge of certain areas of the global football landscape. This managerial profile is also supplemented by a page dedicated to a manager's statistics. Data on this screen is aggregated from player purchases and sales, the amount the manager has earned over the course of the game, match performance, league and cup wins, goals scored and conceded, the number of awards won and the time spent at the current club. This screen also reveals the user's Hall of Fame ranking, an in game sorting of managers past and present. Users can compare themselves to managers with their chosen nationality, managers in the nation in which they are competing, and managers continent-wide and worldwide.

More interestingly, the user's manager is rated using the same 1-20 scale that is employed to rate specific player attributes. However, rather than rating the manager's physical characteristics and talent, the user's manager is rated in the areas of player loyalty, domestic player bias, financial control, hands on approach, squad discipline and tactical consistency. These categories relate to the manager's mental approach and shift and change depending on the decisions the user makes throughout the game experience. Although it is difficult to tell whether these attributes play an important role in shaping how the game unfolds, it would seem that club chairmen would take these numbers into account in deciding whether or not a manager should be hired or fired.

In addition to this quantitative information, at the beginning of each game month, users are sent a message from the chairman with a synopsis of the previous month's performance. This message reports on how the chairman perceives the club's position in the league, recent match outcomes and whether the club turned a profit or suffered a financial loss in the preceding period. From this screen, users can click and access information about their overall performance with respect to competitions, transfers, individual match performance, individual player performance and finances. Within each of these categories, a horizontal bar graph identifies how well the user is performing over and against the expectations established by the club's chairman and fans. These performance graphs 
are subsequently used to determine whether users keep their jobs or are relieved of their duties. The reasons for a firing might be anything from poor match results to unwise financial decisions to irresponsible appeals to the chairmen for more resources of various kinds.

For FM10 to quantify the user in this way is to constitute the user as an entrepreneurial calculable self within a broader context of quantification and risk. With the ascendance of quantitative methods employed in neoliberal governing, Rose notes that we see the rise of the person operating within these boundaries - one who can be "rendered calculable to others and to him- or herself in terms of numbers." 55 Dean agrees with Rose's contention in suggesting that technologies of performance linked to numbers transform professionals into "'calculable individuals' within 'calculable spaces', subject to 'calculative regimes."'56 From Dean's perspective, the calculated self performs in keeping with the standards established under regimes of calculation instead of freely acting as they wish. This appears to hold for FM10 as users come to understand themselves as subject to risk through their managerial profiles and performance graphs. Users cannot evaluate players and their own performances based on their own criteria. Rather, they are positioned to make decisions in accordance with their status as calculable selves who, by virtue of the quantified nature of the experience, are themselves subject to risk management.

As such, not only do users virtually responsibilize the players under their managerial purview, but they themselves become responsibilized through the numbers assessing their performance. Numbers move people to be responsible for their own conduct in that "they turn the individual into a calculating self endowed with a range of ways of thinking about, calculating about, predicting and judging their own activities and those of others." ${ }^{57}$ Managers working from these principles rationalize employee performance via quantification while employees working under these managers attempt to maximize their production quantitatively. In FM10, this internalization of a calculative rationality functions both ways.

In some respects FM10's managerial profile feature completes a circle that began with the quantification of the athlete into a series of ratings. Whereas prior digital sports games enumerated only the athletes and their performances, to have the user's virtual managerial self quantified extends this enumeration to users themselves. As they submit themselves 
to being measured and assessed, users become virtual athletes in their own right subject to the same quantitative discourses and their attendant links to risk and risk management as the athletes being represented. As such, users not only govern through discourses of risk, but are also positioned as potential risks themselves. By positioning users to make decisions based on quantitative information, FM10 naturalizes an entrepreneurial self who must deploy a risk management approach to future outcomes. By positioning users as quantified information, FM10 naturalizes an entrepreneurial self who is responsibilized and subject to risk management.

Even as FM10 quantifies all of this information and positions the user as an entrepreneurial self engaging risk, it also seems possible that the grid of rationality placed over this virtual football world may be eliding any potential failure of neoliberal political rationalities. FM10's persistent imperative to feed the user numbers cloaks the idea that some things cannot be understood apart from quantitative information. Through the numerical assessment of a player's mental abilities or the user's loyalty as a manager, FM10 transforms the subjective into the apparently objective via enumeration. As such, playing the game becomes an exercise in engaging both calculable risk and believing the notion that the incalculable can always be rendered calculable. This constant calculation affirms Beck's insistence on the contemporary "compulsive pretense of control over the uncontrollable, whether in politics, law, science, the economy or everyday life." ${ }^{58}$ FM10 illustrates this pretentious control as it positions users to conduct themselves through calculation on multiple levels.

Although it is certainly possible for users to engage in "counter conducts" 59 and favor a given virtual athlete as a consequence of an emotional attachment to his/her real world counterpart, these kinds of interactions would appear to be infrequent. It is also entirely possible to play FM10 against the intentions of the virtual universe's chairmen, coaches and players. Some users do find great pleasure in creating a managerial profile, appointing themselves as manager of one of their most hated rival teams with this profile and then running the despised club into the financial and footballing ground. These users then turn around and create a new managerial profile, appoint themselves as manager of their favorite squad and enjoy taking advantage of that defanged rival. Other users 
might attempt to create teams made up of only a certain nationality, to sign players from specific countries or form a squad from players with interesting names.

Still others may resort to decision-making based in uncertainty rather than risk. Where governing through risk attempts to render the future objective through quantification, governing through uncertainty focuses on the "singular, infrequently recurring or unique." ${ }^{60}$ Uncertainty differs from risk in that it does not employ quantitative measures as evidence in rational decision-making. Instead, professional judgments, rules of thumb, and experience take precedence over the statistically-based measures more conventionally associated with rationalities of risk. O’Malley is careful to argue that spaces of uncertainty are increasingly discursively absorbed into risk, but maintains that uncertainty still plays a major role in grounding practice. Even as the game positions users to make decisions in accordance with risk management, they may mix uncertaintybased and risk-based decision-making approaches in hybrid configurations as they play.

\section{Conclusion}

To be sure, the video game does not provide a totalizing expression of neoliberalism nor does neoliberalism provide a totalizing explanation of the video game. Rather, video games serve as a space in which specific neoliberal ideas manifest themselves. Any neoliberal ideas that appear in a given video game may be combined and recombined with other types of governmental rationality depending on the game in question. However, at a general level, a governmental approach to the video game reveals neoliberalism's cultural work within some of its common game mechanics, especially with respect to assessing and dealing with risk through discourses of calculation.

For the video game to naturalize a risk management oriented around calculation is to naturalize broader neoliberal discourses of scientifically and actuarially-inflected risk management. The video game mediates this cause-effect understanding of risk and justifies this understanding throughout multiple layers of its gameplay. Beck locates the consequences of this understanding by arguing that it enables the domination 
of "the 'mathematical morality' of expert thought," ${ }^{61}$ a morality that, when combined with a public discourse informed by it hides itself morally and politically. This mathematical morality implies that right ethical decisions are those informed by quantitative data provided only through expertise. Additionally, by rendering the overwhelming majority of information in the game through a quantitative lens, the video game positions the user as homo economicus. Foucault ${ }^{62}$ argues that serious problems derive from an economic approach to life. He questions why the scarce resource model should be consistently applied to a diversity of non-economic situations. Even more problematic, for him, is the idea that rational conduct is only rational when articulated to this economic conduct.

Even as neoliberal risk management appears most prevalent in the contemporary video game, one wonders how video games could change as a consequence of increased social networking, social networking that Terranova $^{63}$ characterizes as production occurring outside of market mechanisms. This non-market production becomes oriented around cooperation rather than the competition that has characterized neoliberalism. She argues that social relations in this space revolve around treating others as human beings instead of actors within a market. Terranova positions these forms of production as a potential check on neoliberal governmentality. Perhaps the individual approach to risk in neoliberalism will be superseded by the cooperation afforded by social networking technologies.

However, even if cooperation should become the hallmark of future video games as a consequence of social networking, it would seem that vestiges of the neoliberal governmentality discussed here would remain, at least in some capacity. As such, it would appear that video games could continue to be situated within a "diagram of post-disciplinary logics of control ... based upon a dream of the technocratic control of the accidental by continuous monitoring and management of risk." ${ }^{64}$

\section{Works Cited}

Baerg, Andrew. "Neoliberalism and the Digital Game." Symploke 17.1-2 (2009): 115-127.

Beck, Ulrich. The Cosmopolitan Vision. Trans. Ciaran Cronin. Cambridge, UK and Malden, MA: Polity Press, 2006. 
-. Risk Society: Towards A New Modernity. London and Newbury Park, CA: Sage Publications, 1992.

- World at Risk. Trans. Ciaran Cronin. Cambridge and Malden, MA: Polity Press, 2009.

Besley, Tina A. C. "Governmentality of Youth: Beyond Cultural Studies.” Contemporary Readings in Law and Social Justice 1.2 (2009): 36-83.

Burchell, Graham. "Liberal Government and Techniques of the Self." Foucault and Political Reason: Liberalism, Neo-Liberalism and Rationalities of Government. Andrew Barry, Thomas Osborne, and Nikolas Rose, eds. Chicago, IL: The University of Chicago Press, 1996. 19-36.

Crook, Tom. "Power, Privacy and Pleasure: Liberalism and the Modern Cubicle." Cultural Studies 21.4/5 (2007): 549-569.

Dean, Mitchell. Governmentality: Power and Rule in Modern Society. London: Sage Publications, 1999.

Fitch, Kristine. "Ethnography of Speaking." Discourse, Theory and Practice. Margaret Wetherell, Stephanie Taylor, and Simeon J. Yates, eds. London: Sage Publications, 2001. 57-63.

Football Manager 2010. Sports Interactive. 30 October 2009. Video Game.

Foucault, Michel. “The Politics of Health in the Eighteenth Century.” The Foucault Reader. Paul Rabinow, ed. New York: Pantheon, 1984. 273-289.

-. The Birth of the Clinic: An Archaeology of Medical Perception. Trans. A. M. Sheridan Smith. New York: Vintage Books, 1994.

—. “17 January 1979.” Birth of Biopolitics: Lectures at the College de France, 1978-79. Michel Senellart, ed. Trans. Graham Burchell. New York: Palgrave MacMillan, 2008. 27-50.

—. “7 March 1979." Birth of Biopolitics: Lectures at the College de France, 1978-79. Michel Senellart, ed. Trans. Graham Burchell. New York: Palgrave Macmillan, 2008. 185-213.

—. “14 March 1979.” Birth of Biopolitics: Lectures at the College de France, 1978-79. Michel Senellart, ed. Trans. Graham Burchell. New York: Palgrave Macmillan, 2008. 215-237.

—. "21 March 1979." Birth of Biopolitics: Lectures at the College de France, 1978-79. Michel Senellart, ed. Trans. Graham Burchell. New York: Palgrave Macmillan, 2008. 239-265. 
—. “28 March 1979.” Birth of Biopolitics: Lectures at the College de France, 1978-79. Michel Senellart, ed. Trans. Graham Burchell. New York: Palgrave Macmillan, 2008. 267-289.

Juul, Jesper. Half-real: Video Games Between Real Rules and Fictional Worlds. Cambridge, MA and London: The MIT Press, 2005.

Kücklich, Julian Raul. "Virtual Worlds and Their Discontents: Precarious Sovereignty, Governmentality, and the Ideology of Play." Games and Culture 4.4 (2009): 340-352.

Lazzarato, Maurizio. "Neoliberalism in Action: Inequality, Insecurity and the Reconstitution of the Social." Theory, Culture \& Society 26.6 (2009): 109-133.

Oates, Thomas Patrick. "New Media and the Repackaging of NFL Fandom.” Sociology of Sport Journal 26 (2009): 31-49.

O'Malley, Pat. "Risk and Responsibility." Foucault and Political Reason: Liberalism, NeoLiberalism and Rationalities of Government. Andrew Barry, Thomas Osborne, and Nikolas Rose, eds. Chicago, IL: The University of Chicago Press, 1996. 189-208.

-. "The Uncertain Promise of Risk." The Australian and New Zealand Journal of Criminology 37.3 (2004): 323-343.

Otter, Chris. “Making Liberal Objects: British Techno-Social Relations 1800-1900.” Cultural Studies 21.4-5 (2007): 570-590.

Patriarca, Silvana. Numbers and Nationhood: Writing Statistics in Nineteenth-Century Italy. Cambridge: Cambridge University Press, 1996.

Perkinson, Henry J. No Safety in Numbers: How the Computer Quantified Everything and Made People Risk-Aversive. Hampton Press Inc.: Cresskill, New Jersey, 1996.

Peters, John Durham. "'The Only Proper Scale of Representation': The Politics of Statistics and Stories.” Political Communication 18 (2001): 433-449.

Peters, Michael A. "The New Prudentialism in Education: Actuarial Rationality and the Entrepreneurial Self.” Educational Theory 55.2 (2005): 123-137.

Pitts-Taylor, Victoria. “The Plastic Brain: Neoliberalism and the Neuronal Self." Health 14.6 (2010): 635-652.

Rigakos, George S. "Risk Society and Actuarial Criminology: Prospects for a Critical Discourse.” Canadian Journal of Criminology 41.2 (1999): 137-150.

Rose, Nikolas. “Governing 'Advanced' Liberal Democracies.” Foucault and Political Reason: Liberalism, Neo-Liberalism and Rationalities of Government. Andrew Barry, Thomas Osborne, and Nikolas Rose, eds. Chicago, IL: The University of Chicago Press, 1996. 37-64. 
—. Powers of Freedom: Reframing Political Thought. Cambridge: Cambridge University Press, 1999.

-. and Peter Miller. Governing the Present: Administering Economic, Social and Personal Life. Cambridge, UK and Malden, MA: Polity Press, 2008.

- and Peter Miller. "Political Power Beyond the State: Problematics of Government.” The British Journal of Sociology 61 (2010): 271-303.

Sicart, Miguel. The Ethics of Computer Games. Cambridge, MA and London: The MIT Press, 2009.

Sports Interactive. “Online Manual.” Football Manager. http://www.footballmanager. $\mathrm{com} / \mathrm{manual} /$ ?locale $=$ en_GB

Starr, Paul. “The Sociology of Official Statistics.” The Politics of Numbers. William Alonso and Paul Starr, eds. New York: Russell Sage Foundation, 1987. 7-58.

Terranova, Tiziana. "Another Life: The Nature of Political Economy in Foucault's Genealogy of Biopolitics.” Theory, Culture \& Society 26.6 (2009): 234-262.

Valentine, Jeremy. “Governance and Cultural Authority." Cultural Values, 6.1, 2 (2002): 49-64.

\section{Notes}

1. Jesper Juul, Half-real: Video Games Between Real Rules and Fictional Worlds (Cambridge, MA and London: The MIT Press, 2005).

2. Nikolas Rose and Peter Miller, "Political Power Beyond the State: Problematics of Government," The British Journal of Sociology 61 (2010): 271-303.

3. Andrew Baerg, "Neoliberalism and the Digital Game," Symploke 17.12 (2009): 115-127; Julian Raul Kücklich, "Virtual Worlds and Their Discontents: Precarious Sovereignty, Governmentality, and the Ideology of Play," Games and Culture 4.4 (2009): 340-352.

4. See Michel Foucault, “7 March 1979,” Birth of Biopolitics: Lectures at the College de France, 1978-79, Michel Senellart, ed., Trans. Graham Burchell (New York: Palgrave Macmillan, 2008), 185-213, p. 186.

5. Graham Burchell, "Liberal Government and Techniques of the Self," Foucault and Political Reason: Liberalism, Neo-Liberalism and Rationalities of Government, Andrew Barry, Thomas Osborne, and Nikolas Rose, eds. (Chicago, IL: The University of Chicago Press, 1996), 19-36; Mitchell Dean, Governmentality: Power and Rule in Modern Society (London: Sage Publications, 1999); Nikolas Rose, Powers of Freedom: Reframing Political Thought (Cambridge: Cambridge 
University Press, 1999); and Jeremy Valentine, "Governance and Cultural Authority,” Cultural Values, 6.1, 2 (2002): 49-64.

6. See Graham Burchell, "Liberal Government and Techniques of the Self."

7. See Nikolas Rose and Peter Miller, Governing the Present: Administering Economic, Social and Personal Life (Cambridge, UK and Malden, MA: Polity Press, 2008), p. 20.

8. Michel Foucault, “17 January 1979,” Birth of Biopolitics: Lectures at the College de France, 1978-79, Michel Senellart, ed., Trans. Graham Burchell (New York: Palgrave MacMillan, 2008), 27-50.

9. See Graham Burchell, "Liberal Government and Techniques of the Self," p. 23-24 (italics in original).

10. See Michel Foucault, “14 March 1979,” Birth of Biopolitics: Lectures at the College de France, 1978-79, Michel Senellart, ed., Trans. Graham Burchell (New York: Palgrave Macmillan, 2008), 215-237, p. 223.

11. See Tina A. C. Besley, "Governmentality of Youth: Beyond Cultural Studies," Contemporary Readings in Law and Social Justice 1.2 (2009): 36-83, p. 47. See also Michael A. Peters, "The New Prudentialism in Education: Actuarial Rationality and the Entrepreneurial Self," Educational Theory 55.2 (2005): 123-137.

12. Michel Foucault, “21 March 1979," Birth of Biopolitics: Lectures at the College de France, 1978-79, Michel Senellart, ed., Trans. Graham Burchell (New York: Palgrave Macmillan, 2008), 239-265; See also Graham Burchell, "Liberal Government and Techniques of the Self"; and Nikolas Rose, Powers of Freedom.

13. See Nikolas Rose, Powers of Freedom.

14. Ibid., p. 261.

15. Pat O'Malley, “The Uncertain Promise of Risk,” The Australian and New Zealand Journal of Criminology 37.3 (2004): 323-343, p. 336.

16. See Nikolas Rose, Powers of Freedom.

17. Silvana Patriarca, Numbers and Nationhood: Writing Statistics in NineteenthCentury Italy (Cambridge: Cambridge University Press, 1996). See also Paul Starr, "The Sociology of Official Statistics," The Politics of Numbers, William Alonso and Paul Starr, eds. (New York: Russell Sage Foundation, 1987), 7-58.

18. Pat O’Malley, “The Uncertain Promise of Risk.”

19. Maurizio Lazzarato, "Neoliberalism in Action: Inequality, Insecurity and the Reconstitution of the Social," Theory, Culture \& Society 26.6 (2009): 109-133, p. 111. 
20. Pat O'Malley, "Risk and Responsibility," Foucault and Political Reason: Liberalism, Neo-Liberalism and Rationalities of Government, Andrew Barry, Thomas Osborne, and Nikolas Rose, eds. (Chicago, IL: The University of Chicago Press, 1996), 189-208, p. 197.

21. Nikolas Rose and Peter Miller, “Political Power Beyond the State,” p. 286.

22. Michael A. Peters, “The New Prudentialism in Education: Actuarial Rationality and the Entrepreneurial Self," Educational Theory 55.2 (2005): 123-137.

23. Ulrich Beck, Risk Society: Towards A New Modernity (London and Newbury Park, CA: Sage Publications, 1992). See also Ulrich Beck, World at Risk, Trans. Ciaran Cronin (Cambridge and Malden, MA: Polity Press, 2009).

24. See Ulrich Beck, World at Risk, p. 11.

25. Michel Foucault, The Birth of the Clinic: An Archaeology of Medical Perception, Trans. A. M. Sheridan Smith (New York: Vintage Books, 1994), p. 89.

26. George S. Rigakos, "Risk Society and Actuarial Criminology: Prospects for a Critical Discourse,” Canadian Journal of Criminology 41.2 (1999): 137-150.

27. See Ulrich Beck, Risk Society, p. 72 (italics in original).

28. Ulrich Beck, World at Risk.

29. See Mitchell Dean, Governmentality: Power and Rule in Modern Society (London: Sage Publications, 1999); Pat O’Malley, “The Uncertain Promise of Risk"; and Nikolas Rose, Powers of Freedom.

30. Nikolas Rose, Powers of Freedom, p. 160.

31. Pat O’Malley, “The Uncertain Promise of Risk.”

32. Nikolas Rose and Peter Miller, "Political Power Beyond the State,” p. 281.

33. See Nikolas Rose, Powers of Freedom; and Nikolas Rose and Peter Miller, Governing the Present: Administering Economic, Social and Personal Life (Cambridge, UK and Malden, MA: Polity Press, 2008), p. 16.

34. See Nikolas Rose and Peter Miller, Governing the Present, p. 32.

35. Nikolas Rose and Peter Miller, “Political Power Beyond the State,” p. 281.

36. Kristine Fitch, "Ethnography of Speaking," Discourse, Theory and Practic, Margaret Wetherell, Stephanie Taylor, and Simeon J. Yates, eds. (London: Sage Publications, 2001), 57-63.

37. Chris Otter, "Making Liberal Objects: British Techno-Social Relations 18001900," Cultural Studies 21.4-5 (2007): 570-590.

38. Tom Crook, "Power, Privacy and Pleasure: Liberalism and the Modern Cubicle," Cultural Studies 21.4/5 (2007), p. 568. 
39. Pat O’Malley, “The Uncertain Promise of Risk,” p. 27.

40. Henry J. Perkinson, No Safety in Numbers: How the Computer Quantified Everything and Made People Risk-Aversive (Hampton Press Inc.: Cresskill, New Jersey, 1996).

41. Nikolas Rose, Powers of Freedom, p. 247.

42. Nikolas Rose, “Governing 'Advanced' Liberal Democracies,” Foucault and Political Reason: Liberalism, Neo-Liberalism and Rationalities of Government, Andrew Barry, Thomas Osborne, and Nikolas Rose, eds. (Chicago, IL: The University of Chicago Press, 1996), 37-64.

43. See Mitchell Dean, Governmentality.

44. Nikolas Rose, Powers of Freedom, p. 213.

45. Ibid.

46. See Nikolas Rose, Powers of Freedom.

47. Nikolas Rose and Peter Miller, "Political Power Beyond the State,” p. 281.

48. Football Manager 2010, Sports Interactive, 30 October 2009, Video Game.

49. Thomas Patrick Oates, "New Media and the Repackaging of NFL Fandom," Sociology of Sport Journal 26 (2009): 31-49.

50. John Durham Peters, "'The Only Proper Scale of Representation': The Politics of Statistics and Stories," Political Communication 18 (2001): 433-449.

51. Sports Interactive, “Online Manual,” Football Manager, para.1. http://www. footballmanager.com/manual/?locale=en_GB

52. Nikolas Rose, Powers of Freedom.

53. Michel Foucault, "The Politics of Health in the Eighteenth Century," The Foucault Reader, Paul Rabinow, ed. (New York: Pantheon, 1984), 273-289.

54. Ibid., p. 279.

55. Nikolas Rose, Powers of Freedom, p. 213.

56. Mitchell Dean, Governmentality, p.169.

57. Nikolas Rose, Powers of Freedom, p. 214.

58. Ulrich Beck, The Cosmopolitan Vision, Trans. Ciaran Cronin (Cambridge, UK and Malden, MA: Polity Press, 2006), p. 22.

59. Maurizio Lazzarato, “Neoliberalism in Action,” p. 114.

60. Pat O’Malley, “The Uncertain Promise of Risk,” p. 13.

61. Ulrich Beck, The Cosmopolitan Vision, p. 142. 
214 Andrew Baerg

62. Michel Foucault, “28 March 1979,” Birth of Biopolitics: Lectures at the College de France, 1978-79, Michel Senellart, ed., Trans. Graham Burchell (New York: Palgrave Macmillan, 2008), 267-289.

63. Tiziana Terranova, "Another Life: The Nature of Political Economy in Foucault's Genealogy of Biopolitics," Theory, Culture \& Society 26.6 (2009): 234-262.

64. Nikolas Rose, Powers of Freedom, p. 235. 
Chapter 8

\title{
Neoliberalism in Publishing
}

\section{A Prolegomenon}

\author{
JEFFREY R. Di LEO
}

Neoliberalism has been eating away at publishing culture for a long time now. Its ascent in the publishing world is one of a gradual intensification of market considerations over aesthetic or scholarly ones-a story that holds to varying degrees both within the corporate publishing industry and now within the university and small press publishing world. However, it is not one that has been widely considered-though it needs to be. The aim of this chapter is to provide a prolegomenon to neoliberalism in publishing and to encourage others to consider the connections between the publishing world and the legacies of neoliberalism. The hope is that an understanding of the destructive powers of neoliberalism within the publishing world will empower and encourage authors and scholars to work to disrupt its further development and continued ascent through acts of resistance. ${ }^{1}$

The rise of neoliberalism within the publishing world has displaced many of its traditional ways of operating. For example, today most authors do not deal directly with large presses anymore, rather this is left to their agents ${ }^{2}$; market data rather than aesthetics drives most large press decision making; the large presses essentially "own" the major book review outlets; multinational publishing corporations control the distribution of books to the majority of stores; and the advances offered by large presses many times exceed the lifetime income of many authors. These and other factors centered upon increased control of the book market have created a disbalance in the publishing world wherein the big 
presses keep getting bigger, more powerful, and fewer in number, and the smaller presses either get absorbed by the bigger ones or get smaller and more marginalized.

Moreover, the recent shift from a print to a digital book culture has only intensified the effects of neoliberalism in publishing. Not only are presses-both large and small-increasingly refusing to publish books that they fear will lose money or only appeal to a limited share of the market, but the number of physical venues to purchase these books is decreasing. As it becomes increasingly possible to find and purchase just about any book you are looking for through an online vendor such as Amazon.com, it becomes increasingly impossible to run a bricks-andmortar bookstore. Not only are private bookstores gradually disappearing from towns and cities across America, so too are the large chain bookstores that hastened the decline of the private bookstores. Bookstores like public libraries should be treated as public spaces where people can gather and seek out written entertainment, edification, and enlightenment, or, if you will, infotainment. They are also often the site of readings, book signings, discussion groups, and other activities grounded in dialogue and critical inquiry - two of the cornerstones of democratic culture. The demise of the bookstore is a major setback for democratic culture, and an example of the way in which public spaces are privatized under neoliberalism.

"Neoliberalism," writes Alfredo Saad-Filho and Deborah Johnston, "straddles a wide range of social, political, and economic phenomena at different levels of complexity." ${ }^{3}$ Inquiry into the ways in which it straddles the publishing world will reveal some of the ultimate constraints neoliberalism places on the marketplace for creativity and ideas. If profit generation and market considerations are the primary drivers of the publishing industry, and the publishing industry controls a major section of information and creative dissemination including major book review outlets and other media, then there is not much hope that heterodox, innovative, and transformative thinking will be supported by it. Furthermore, the monopoly of this industry on knowledge dissemination threatens to render silent major avenues of creative innovation and critical dissent. In a way, small presses today are our best hope for overcoming the neoliberal publishing stranglehold, but they are also the most 
vulnerable, particularly as external support for them from agencies such as the National Endowment for the Arts and state-sponsored arts-councils declines. But how did the publishing world get here? What follows are a few snapshots from the story-a story that oddly enough can be said to begin with arguably the greatest - and most innovative-book of the twentieth-century: James Joyce's Ulysses.

\section{The Rise of Corporate Publishing}

In 1932, when Random House sought to legally publish Ulysses in the United States, it was Bennett Cerf, one of the co-owners of the publishing house that contacted the Irish novelist. After receiving Joyce's consent to publish, Cerf had a copy of the book sent from Paris to New York, and then arranged for customs officials to seize it at the docks so that he could prepare for a court battle over it. Ten minutes after Judge John Woolsey of the New York district court delivered his verdict that the book was not legally obscene, Cerf had the typesetters at Random House working on Joyce's masterpiece. ${ }^{4}$

To many, Cerf, who co-founded Random House in 1925 with Donald Klopfer, and whose press also published Sinclair Lewis, William Faulkner, Gertrude Stein, Truman Capote, and John O'Hara, is one of the heroes of American publishing. Though Joyce's book had been published some ten years earlier by Sylvia Beach's Shakespeare \& Co. in Paris, because it was banned in the English-speaking world, Joyce did not profit from it until Cerf stood up for it in court. The legal publication of Ulysses by Random House finally allowed Joyce-rather than the Ulysses bootleggers - to reap more of the financial rewards of its publication.

In hindsight-and from a less flattering perspective-moves like Cerf's acquisition of Ulysses and the building of a top-tier list of authors by his press can be seen as laying the groundwork for the rise of contemporary corporate publishing. That is to say, it foreshadows a publishing world where Simon \& Schuster is a subsidiary of CBS, and HarperCollins is owned by News Corporation, the multimedia conglomerate founded by Rupert Murdoch; where twelve publishers out of approximately 85,000 account for almost two-thirds of US trade and mass-market book sales $^{5}$; where $90 \%$ of active publishers account for less than $10 \%$ of total 
book sales ${ }^{6}$; where Random House alone accounts for over $13 \%$ of all US book sales and has world-wide sales revenues of almost 2.4 billion dollars ${ }^{7}$; and where Random House alone almost sells more books than 58,795 US trade and mass-market publishers combined. ${ }^{8}$ How did this happen? How did it come to be that a few publishing corporations now control the majority of book sales in the United States? And what does it mean for the 58,795 "small" presses that reside in the shadows of corporate publishing giants like Random House?

In the case of Random House, by the 1950s, the co-owners began to worry about what would happen to the company if one of them died. Cerf said, "Donald and I knew that the real value of the company had increased each year, but nobody knew by how much." ${ }^{\circ}$ He continued, "If its value was too high, how could the survivor afford to buy the other half, and how could the widow of the one who died raise enough cash to pay the estate tax?" ${ }^{10}$ Worries about the future of their company if one of them died led Cerf and Klopfer to sell $30 \%$ of their stock to the public in 1959. "From then on," writes Cerf, "we were publishing with one eye and watching our stock with the other." 11 "Instead of working for yourself and doing what you damn please, willing to risk a loss on something you want to do, if you're any kind of honest man, you feel a responsibility to your stockholders," wrote Cerf. ${ }^{12}$

Going public opened the door to expanding the business, which it did shortly after going public by acquiring both Knopf ${ }^{13}$ and Pantheon. ${ }^{14}$ Soon Time-Life took an interest in merging with Random House-a deal that eventually fell through when it became clear that the US Department of Justice would most likely oppose the merger on anti-trust grounds. ${ }^{15}$ In 1965, however, Random House was sold to RCA for 40 million dollars, at which point Cerf stepped down as president. Cerf said they accepted RCA's offer because "it was one of the great corporations of the country." ${ }^{16}$ And who would disagree-the sale even allowed one of RCA's writers, Truman Capote, to become one of its recording artists, releasing an album of readings from scenes from In Cold Blood in 1966.

By the time Random House was acquired by RCA, it was a much different publishing house from the one where Cerf wrote to Joyce about publishing Ulysses. Further acquisitions and mergers followed including its sale in 1980 from RCA to S.I. Newhouse, a wealthy businessman and 
owner of a range of television stations, newspapers, and magazines, to its sale again in 1998 to Bertelsmann. ${ }^{17}$ Today "Random House" consists of over 60 imprints, divisions, and groups in the US and UK alone-with one of the imprints of "Random House" called "Random House."18

Random House is a perfect example of the effects the rise of a ruthless new form of market capitalism that activists and scholars have been warning us about for years. "It reifies and glorifies the reign of what are called the financial markets," comments Pierre Bourdieu, "in other words the return to a kind of radical capitalism, with no other law than that of maximum profit, and unfettered capitalism without any disguise, but rationalized, pushed to the limit of its economic efficacy by the introduction of modern forms of domination, such as 'business administration,' and techniques of manipulation, such as market research and advertising." ${ }^{19}$ Moreover, Random House's recent merger with another of the largest publishing houses in the world, Penguin, is only further evidence of the continuing ruthlessness of this new form of market capitalism. ${ }^{20}$

On October 29, 2012, a day that will go down in neoliberal publishing history infamy, the two largest trade-book publishing corporations in the world-Random House and Penguin — announced that they will be merging. If approved by government regulators, the new Penguin Random House will account for about one in four books sold worldwide. Worldwide revenues from this new publishing company will be in the neighborhood of 4 billion dollars. However, the annual revenues of Penguin's parent company are even larger. ${ }^{21}$

Pearson, the UK corporation which owns the Penguin Book Group, is by far the largest publishing corporation in the world with annual revenues of nearly 8.5 billion dollars. It has 41,000 employees in 70 countries, and publishes over 4,000 fiction and non-fiction books per year. Pearson Education is the source of $75 \%$ of its revenues, whereas the remainder are divided between Penguin (18\%), and the Financial Times (7\%). ${ }^{22}$

Though roughly a quarter the size of Penguin, Random House is the eighth largest publishing company in the world. Owned by Germany's Bertelsmann AG, Random House had annual revenues in excess of 2.2 billion dollars in 2011. However, with revenues in excess of 3.8 billion the previous year, one wonders what role this revenue loss played in their merger with Penguin. ${ }^{23}$ 
To put these revenue and publishing numbers in some context, remember that of the 85,000 publishers in the Bowker database, twelve of them account for almost two-thirds of US trade and mass-market book sales-and now one of them will account for one-quarter alone. Also recall that the annual revenues of Penguin Random House will be more than the combined revenues of 58,795 US trade and mass-market publishers, that is, over $95 \%$ of all US publishers. ${ }^{24}$

This enormous financial and market-share advantage has created a lot of concern - and both companies are working hard to contain it. Markus Dohle, Random House chairman and CEO, who will assume the position of CEO of the new combined publishing company, wrote to his Random House colleagues that he aims "to retain the distinct identities of both companies' imprints." 25 Distinct identities? Who is he kidding? That world was lost when Random House went public and started swallowing up publishing houses back in the 1960s.

It bears remembering that both Random House and Penguin have already absorbed much of their competition over the past fifty years. In the United States alone Random House includes the imprints Alfred A. Knopf, Anchor, Ballantine, Bantam, Broadway, Clarkson Potter, Crown, Delacorte, Dell, Del Rey, Dial, Doubleday, Everyman's Library, Fawcett, Fodor's Travel, Golden Books, Harmony Ivy, Kids@Random, Main Street Books, Nan A. Talese, One World, Pantheon, Random House, Schocken, Shave Areheart Books, Spectra, Spiegel \& Grau, Strivers Row Books, The Modern Library, Three Rivers Press, Villiard, Vintage, and Wellspring, and Penguin Book Group includes Ace, Alpha, Avery, Berkley, Current, Dial Books, Dutton, Firebird, Frederick Warne, Gotham, G. P. Putnam's Sons, Grosset \& Dunlap, HP Books, Hudson Street Press, Jeremy P. Tarcher, Jove, New American Library, Penguin, Penguin Press, Perigee, Philomel, Plume, Portfolio, Price Stern Sloan, Puffin, Putnam, Riverhead, Sentinel, Speak, Tarcher, and Viking. Add to this list the UK imprints of both companies, and the combined Penguin Random House company will result in over 100 different imprints in the US and UK alone. The only distinctive difference that will come out of this new company are its profits - which will be the largest ever by one company in the history of trade publishing. 
There is also worry that authors will lose more of their creative autonomy and will be reduced even more to merely equations or numbers by the new mega-corporation. To assuage this fear, Dohle wrote in the same letter that "authors remain the center of everything we do" and that "creative autonomy" "will be a defining hallmark" of Penguin Random House. ${ }^{26}$ It is one thing for Dohle to say it, but quite another to realize it in a publishing environment where capital — not creativity — is the prime directive, and where autonomy must be cleared by the accounting office. Of all the things in Dohle's letter, the least controversial is his claim that the other defining hallmark of Penguin Random House will be "great resources." We know what this will mean for shareholders, but what will this mean for authors, agents and readers?

A major fear of course is that reduced competition between Random House and Penguin will result in lower advances and profits for authors and agents, and fewer publishing options for writers - now that the two of the Big Ten are One. Both Dohle and John Makinson, who is slated to become Chairman of the new company, and who is currently Chairman and CEO of Penguin, try to calm these concerns. In fact, Makinson writes in his letter to the global Penguin Group that "exactly the opposite will happen," namely that the "publishing imprints of the two companies will remain as they are today, competing for the very best authors and the very best books." ${ }^{27}$ But again, it is hard to believe that the merger will result in more choices and more competition in the book industry. So are we really to believe that the imprints of this company are going to compete vigorously against each other for titles? I don't think so but let's hold off on this question for a moment.

Make no mistake: this merger and other mergers like it are not about protecting creative autonomy or bringing about more opportunities for authors and options for readers. Rather, it is about maximizing profit in an industry that is rapidly changing. In fact, it may be more about the digital transformation of the publishing world than anything else. And the competition may not be from within the publishing world, but rather from the distribution and sales world.

Amazon reports that it sells 114 e-books for every 100 printed books. ${ }^{28}$ And it has been predicted that it will soon account for 50\% of US trade sales in all formats. ${ }^{29}$ Dohle's letter indirectly confirms their worries about 
the challenges presented by Amazon when he says that the merger "will accelerate our digital transformation, while ensuring a strong future for print." He also says that it will put them in a better position "to provide copyright protection, and to support our authors' intellectual property."

There is no doubt that the publishing industry has been forever changed by the rise of neoliberalism. This form of unfettered capitalism, says Bourdieu, "sets up as the norm of all practices, and therefore as ideal rules, the real regularities of the economic world abandoned to its own logic, the so-called laws of the market." ${ }^{30}$ While it has its roots in the classical liberal economic theories of Adam Smith and David Ricardo, it is more closely associated with the neoliberalism of Friedrich Hayek and Milton Friedman. As a consequence, it has resulted in among other things, the rise of authoritarianism, the suspension of civil liberties, the privatization of public spaces, the upward distribution of wealth-and in our case, the disfigurement of the book publishing industry. Again, as Henry Giroux succinctly puts it, "neoliberalism is an ideology and politics buoyed by the spirit of a market fundamentalism that subordinates the art of democratic politics to the rapacious laws of a market economy that expands its reach to include all aspects of social life within the dictates and values of market-driven society." ${ }^{11}$ The case of publishing is yet another sad chapter in the subordination of social life by neoliberalismas the books that we read are an integral part of it.

To be sure, there is no aspect of the publishing world that has not been affected by its economic control and cultural domination of the market. What though does the rise of neoliberalism and corporate publishing mean for the 58,795 "small" presses ${ }^{32}$ that reside in the shadows of corporate publishing giants like Penguin Random House? Is their position any different than it was before Random House went public and was purchased by RCA or merged with Penguin? And what is the effect of the rise of neoliberalism in the publishing on fiction writing, reading habits, and bookselling? Is writing for Cerf and Klopfer any different than writing for Rupert Murdoch or RCA? These and related questions go straight to the foundation of book and creative writing culture in America and have a significant impact on the shape and future of our critical and creative legacies. 


\section{The Aesthetics of Profit}

The rise of neoliberalism has forever changed mainstream fiction writing, reading habits, and bookselling in America. Writing fiction in the age of corporate mega-publishing is now more than ever a business affair, not a creative one. In Acts of Resistance, Bourdieu writes "neo-liberal ideologues want us to believe that the economic and social world is structured by equations." ${ }^{33}$ In terms of the publishing world, they likewise want us to believe that it too is structured by equations.

Now that reading habit data can be tracked through data mining of e-books, publishers can determine everything from how long it took you to read a page to specifically what you read. ${ }^{34}$ What then will stop them from feeding this data back into their publishing equations to determine things like the economically optimal narrative aesthetics? How far are we from aesthetics being more than just influenced by market-fundamentalism, but rather determined by it? After all, this and other data determined the books stocked by the fistful of chains that dominated the national landscape (though, see below, where it got them). Using data now to determine the shape of narrative seems like a logical next step.

Nearly three-quarters of active publishers in the US have annual revenues between zero and \$50,000; roughly another twenty percent put their annual revenues between $\$ 50,000$ and one million dollars. In total, these figures represent the annual revenues of almost 60,000 - or $95 \%$ of US publishers. ${ }^{35}$ Considering the large percentage of publishers with annual revenues less than 50 thousand dollars, it could be argued that small press publishing populates the national landscape though corporate publishing controls it. How else can you describe the difference between a Penguin Random House that will now produce one in every four new books and a small press like the Fiction Collective Two that only publishes six books per year total?

One might argue that what separates a corporate publisher from a small press publisher is that the former want people to buy books, whereas the latter want people to read them-or even believe in them. In a way, the American political landscape mirrors the publishing landscape. Namely, a case could be made that political power is concentrated among the wealthiest $5 \%$ percent of our nation, whereas the remaining 95\% dominate in numbers. Whereas in American politics wealth yields 
a disproportionate amount of political power, in American publishing, capital yields a disproportionate amount of market control.

The great myth of American publishing is that it is controlled by aesthetic values. This might have been the case years ago when the Random House of Bennett Cerf pushed to publish a novel which opens with the line "Stately, plump Buck Mulligan came from the stairhead, bearing a bowl of lather on which a mirror and a razor lay crossed." It is not the case when its contemporary neoliberal instantiation outbid itself to publish the next novel of the author whose first novel began with the line "At the first gesture of morning, flies began stirring." ${ }^{36}$ Yes, outbid itself. Which is either like tripping over your own shoelaces-or tripping over the outstretched foot of the editor in the cubicle next to you.

The novel that got Random House tripping over their own feet was a first novel whose hardback sales in the late 1990s had exceeded 1.6 million copies. Such things capture the attention of market-driven corporate publishers - "At first gesture of a market, calculators began stirring." Based on what is said to have been a one-page proposal, one of Random House's 60 imprints, divisions, and groups offered an advance of over five million dollars to the author. However, not to be outdone by one of their co-division rivals, another division of Random House offered over eight million dollars. ${ }^{37}$ The name of the novelist and whether the advance paid off for Random House are irrelevant to the conditions that they exemplify: the effects of neoliberal-based decision-making in the publishing world. ${ }^{38}$

A climate of publishing where the advance for a second novel exceeds by eight times the annual publishing revenue of $95 \%$ of American publishing houses-or roughly 60,000 publishers-presents a sad state for American letters. If Random House was willing to offer the author of this second novel an eight million dollar advance, one can only imagine how much they were willing to invest in marketing the book. That is, for example, in purchasing mainstream media interest in this author and their work as "essential summer reading" or buying national distribution support to ensure that "the next great American novel" is available for purchase in your local Wal-Mart or Borders. To say that hearing this book news over and over again in major media outlets, and seeing this book prominently displayed in every big box bookstore in America doesn't 
affect reading habits and impact sales would be naïve. However, to say that it fashions reading and buying behavior would be closer to the truth.

American publishing in the age of neoliberalism is controlled by markets, equations, and calculators - not aesthetic value, literary contribution, or scholarly impact. The more that mega-publishers invest in large market fiction and avoid small market fiction, the more that aesthetic innovation and narrative diversity will flourish among small presses. In the neoliberal climate of corporate publishing, it is not surprising to see a rise in small press publishers devoted to diversity and innovation-and a widening of the financial gap between small presses and the corporate giants. Moreover, even among the big house publishers, one is beginning to see more capital distance among them.

Of the 4,000 publishers that have annual sales over one million dollars, less than twenty percent have annual sales over fifty-million dollars ${ }^{39}$ —and only 12 have annual sales over 150 million. ${ }^{40}$ And among the Big 12 , the twelfth largest has only one-tenth of the sales of the largest. This kind of concentration of publishing capital entails a type of power akin to that held by the Bush and Kennedy families in American politics. Again, that Random House alone sells more books than 76,500 US trade and mass-market publishers combined and that the newly merged Penguin Random House will only increase this number is as much a cause for celebration among writers as is the fact that McDonald's serves more hamburgers than any other restaurant in America. So, would you like to supersize that novel?

\section{The Decline and Fall of the Bookstore}

One of the more visible signs of neoliberalism in publishing has been the decline of independent booksellers - and the corresponding rise of the book superstore. While corporate publisher mergers, market-based editorial decision-making, and multi-million dollar author advances are less visible to the general public, huge book megastores - often near boarded up independent bookstores - are a part of the American landscape. Book superstores are as common now to American strip malls as Wal-Mart and Target, and in some cities are even found among luxury stores such as Louis Vuitton and Tiffany's. 
Fifty years ago, three quarters of trade books were purchased at independent bookstores. Thirty years ago, competition from mall bookstores slashed this number in half. The meteoric rise of superstores like Barnes and Noble and Borders cut this number in half again five years ago. ${ }^{41}$ What's not to like about cappuccino machines, cozy leather chairs, and a mountain of the Tom Clancy novels? But now it seems even the megastores have overreached their rise.

One half of the contemporary book-superstore dynamic duo recently filed for bankruptcy. It seems that while everyone did enjoy the cappuccino machines, cozy chairs, and free reading materials, this didn't necessarily translate into the actual sale of books. And while Borders' recent filing for Chapter 11 might be sweet revenge to those who ran and loved the independents, don't expect a renaissance of the independent bookstore. Consumers increasingly prefer to shop for books online, where they can find big discounts and take advantage of immediate download.

The demise of Borders only strengthens online bookselling giant Amazon, which again will soon account for half of all US trade sales. To get a perspective on this number, consider that only five years ago, all of the superstores and chains in the US combined only accounted for $45 \%$ of the US book retail market. ${ }^{42}$ Soon Amazon alone will be responsible for half of all book sales in the US - with and without cappuccino.

If there is a silver lining to this development, at least Amazon makes available many more small-press books than Borders and its corporate companions - and easily fills your order for a title by Raymond Federman or Cris Mazza. Shopping at the chains never did that (I make a habit of looking for my favorite innovative and small press authors in every bookstore I visit). Much like Random House, whose transformation from premier literary publishing house to market-fundamentalist mega-corporation can be linked to its going public and its corporate takeover by RCA, the metamorphosis of Borders from darling of the independent bookstore world to its pariah can be associated with its purchase by another large corporation-in this case, Kmart.

In 1971, Tom and Louis Borders opened a small bookstore in the college town of Ann Arbor, Michigan. Its success over the years encouraged the owners to open a second store in 1985 in nearby Detroit. When this store did well, they opened others. The stores were known throughout the 
Midwest and Northeast for their wide selection of new titles, but Borders stores retained their roots as academic booksellers. At any Borders, one could find piles of bestsellers alongside thousands of individual copies of scholarly titles - something unusual at the time for a bookstore chain. Kmart, renowned for its "blue-light specials" on underwear and soap, acquired Borders in 1992, and merged it with Waldenbooks, the mall bookstore staple that it had acquired in 1984. The merger, called Borders Group, went public in $1995 .^{43}$

While the acquisition of bookstore chains by a department store might sound strange, it seems fitting given that at one point department stores in the US were among the leading sellers of books. Shortly after they first starting selling books in late nineteenth century, department stores likes Macy's of New York became national leaders in book sales. And by the early 1950s, it has been estimated that between twenty to forty percent of trade books were sold by department stores. These businesses favored books in their inventory because they were believed to raise the class of the store, and appealed to a more cultured — and wealthy—clientele. ${ }^{44}$

One of the consequences of this corporate merger with Kmart was that Borders Group started closing many of its Waldenbooks, and opening up more Borders superstores. From 1993 to 1994 alone, Borders went from 44 to 85 superstores-whereas Waldenbooks was reduced by nearly 60 stores during the same period. ${ }^{45}$ And Borders was not the only bookstore increasing its number of superstores at the time: so too was Barnes and Noble, which had bought the other mall chain bookstore staple, B. Dalton Booksellers, in 1986. By 2006, the number of Borders superstores rose to nearly 500 in the US alone-often in prime locations such as on Chicago's Magnificent Mile or Market Street in San Francisco. But Borders' fall has turned out to be faster than its rise. ${ }^{46}$

To be sure, Borders Group's failings were not just about books. A poor real estate strategy, over-investment in music (another anguished industry), and inefficient inventory management contributed to the decline. When the company filed for bankruptcy on February 16, 2011, Borders hadn't been profitable for five years. In 1994, Borders Group operated almost twelve hundred bookstores. Just before filing for bankruptcy, there remained one half that number-and another thirty percent were set to close. ${ }^{47}$ Fittingly, the vacant shells of these large stores in prominent 
locations like Michigan Avenue in Chicago are as much a visual reminder to all who pass by them of the shortcomings of market-fundamentalistbased decision-making as are the piles of remaindered book-mountain titles. These vacated stores are a highly visible sign of the emptiness of neoliberal practices in publishing.

So what now for the independent booksellers? The difference between the book superstore and an independent bookseller ends with the common trait that they both stock and sell books. Whereas independent bookstores are defined for their eclectic and idiosyncratic inventories, mall bookstores like B. Dalton and Waldenbooks, and superstores like Barnes and Noble and Borders are characterized by the consistency and homogeneity of their inventories. While each independent bookstore makes its own inventory decisions, department stores and corporate chains have a few people making purchasing decisions for all of their stores.

The recent rise of chains aimed to simulate the appearance of highend independent bookstores by having rows of beautiful bookcases with ladders alongside plush chairs and gourmet coffee, but in the process destroyed the aura of the bookstore. By regulating and standardizing the appearance and stock of the corporate bookstore in the same way that McDonald's regulates and standardizes its appearance and menu, they in effect deconstructed the notion of the bookstore they sought to emulate. Just as independent restaurants don't look alike or have the same menu-let alone food that tastes exactly the same-independent bookstores don't all sell the same books or look alike. That's the beauty of independence.

Browsing an independent bookstore for the first time can be an unsettling experience. The unfamiliarity with the layout and organization of titles, and with the stock itself, lends an element of adventure. At their best, independent books are unique assertions of aesthetic tastes. Mass market chain stores, however, sacrificed adventure for familiarity. Their over-reliance on bestsellers and reluctance to embrace valuable backlist titles led to a homogenizing of offerings. But now even this strategy is failing.

As the industry undergoes a painful contraction, booksellers and publishers will need to reexamine their relationship in a changing market. 
It's unfortunate that a number of jobs will be lost, and that there will be fewer places to physically browse for books. But perhaps there is a positive element for small-press authors. Perhaps with the decline of the mass-market chains, the lure of "big" books for quick bucks will be somewhat lessened. Perhaps booksellers and publishers will reinvest in a longstanding relationship of developing authors and promoting backlist titles, as they did before mass merchandising changed the process. Well-written manuscripts from lesser-known authors might have more of a voice in an environment less dependent on mounds of bestsellers. And who knows, writers and readers just might benefit from some of the recent failures of corporate publishing.

\section{The Disappearing University Press}

If the fall of the decline and fall of corporate and independent booksellers has been one of the more visible signs of neoliberalism in publishing, then one of the least visible signs is the gradual fall and disappearance of university presses. Of all of the consequences of neoliberalism in publishing, this is the most devastating to academic culture. While there are only just over 130 university presses in the United States, these presses are the lifeblood of scholarly publishing in the United States. ${ }^{48}$ The scourge of neoliberalism in higher education has led to a spate of downsizing and closures. The latest university press to face closure is the publisher of The Collected Works of Langston Hughes and The Complete Sermons of Ralph Waldo Emerson. Starting July 2012, the University of Missouri Press began to phase out operations. ${ }^{49}$ The press, which was founded in 1958 by a University of Missouri English professor, William Peden, has published approximately 2,000 titles over the course of its history.

Eclectic in its reach, the press has an impressive catalogue ${ }^{50}$ that includes offerings in women's studies, African-American studies, creative nonfiction, journalism, and American, British, and Latin American literary criticism. It serves its region with series such as the Missouri Biography Series and Missouri Heritage Readers Series, and American letters in general with series such as the Mark Twain and His Circle Series and the Southern Women Series. The press' catalogue is deep and rich, and holds gems for both the serious scholar and general interest reader. 
In addition to the seminal collections of Emerson and Hughes, my own recent favorites are Gail Pool's Faint Praise: The Plight of Book Reviewing in America (2007) and Ned Stuckey-French's The American Essay in the American Century (2011). ${ }^{51}$

One of the measures of a great university is the strength of its press. Press strength is determined by its catalogue, and its catalogue by the choices of its editors and the impact of its authors. Still, not every prestige indicator is marked in this direction. For example, the existence of a great university press is neither sufficient nor necessary for membership in the prestigious Association of American Universities. Last year, University of Nebraska, which operates one of the best university presses in the country, was ousted from the AAU; and Georgia Institute of Technology, which does not run a press, was recently admitted. The University of Missouri will neither be ousted nor even punished by the AAU for closing its press. The AAU criteria favor competitive research financing, not competitive catalogues; faculty in the National Academies, not award-winning university press titles.

University presses are nonprofit enterprises. Though these presses may reach a level of financial self-sufficiency in their operation, they are by and large underwritten by their host universities. This is part of the investment of higher education. Most of the monographs produced by scholars have a limited audience-and very few make their publishers any money. However, their publication is still an important aspect of scholarly activity and knowledge dissemination.

The University of Missouri system afforded its press a $\$ 400,000$ annual subsidy. ${ }^{52}$ To gain a perspective on this figure and the value of the press to the university, one only has to consider that the head basketball coach at Mizzou makes $\$ 1.35$ million per year-and the head football coach makes $\$ 2.5$ million per year. ${ }^{53}$ The interim director of the press makes just under $\$ 75,000$ - less than an assistant baseball coach. ${ }^{54}$ The acquisitions editor makes just under $\$ 35,000$ - less than an athletic trainer. Closer to the cost of subsidizing the press are the salaries of the assistant head football coach and the linebacker coach/defensive coordinator, who each make just over $\$ 340,000$ per year. ${ }^{55}$ How does one compare a football season to a publishing season? Is an 8-5 season more 
valuable than 30 books published $?^{56}$ Is running a press worth losing an assistant coach or two?

In total, the University of Missouri employs over 17,500 individuals. Currently, the press employs 10 people though in 2009 it was nearly twice that number. The economic crash of 2008 forced many state universities such as the University of Missouri to reassess priorities and scale back. ${ }^{57}$ Mizzou made their priorities clear: in 2010, the University of Missouri's head football coach received a $\$ 650,00$ raise. ${ }^{58}$ Louisiana State University, another football powerhouse, slated its university press for closure in 2009. Somehow, this press survived the state budget crisis. ${ }^{59}$ However, given that it is nowhere near as popular as their football team, I'm sure that it sleeps with one eye open, waiting for the day that university officials have to decide between a subsidy for the press-and a pay raise for the coach. Other presses were not so lucky. Eastern Washington University, Southern Methodist University, ${ }^{60}$ and the University of Scranton ${ }^{61}$ all closed their presses. And even the celebrated University of California Press tightened its belt by discontinuing a poetry series. ${ }^{62}$

University of Missouri administrators are said to be "hashing out ways to create a new and sustainable model to operate a university press." ${ }^{63}$ They also assure us that "any future press won't look like the current operation." ${ }^{64}$ "We believe the publication of scholarly work is important," said the president of University of Missouri. "We're working very diligently on what" the new press "will look like." ${ }^{5}$ While there is no indication where the University of Missouri administration will go with this, the options here are limited. The most obvious, however, is to go digital. And here there is some precedent.

Though Rice University closed its traditional press in 1996, it reopened in its wake an all-digital press in 2006. According to a 2010 interview with Eugene Levy, who helped finance the revived press during his term as provost at Rice, the all-digital press was costing Rice $\$ 150,000$ to $\$ 200,000$ per year. “This was intended as an experiment," said Levy. ${ }^{66}$ Coming from the Andrew Hays Buchanan Professor of Astrophysics at Rice the word "experiment" gains even more gravitas. Rice hoped to save money by not printing books. Comments Levy, "The hope was that, without the burden of having to maintain a print inventory, the press might sustain itself largely on revenues from print-on demand sales." What the 
university found out was that there "are base costs that are irreducible""and that printing is only one of them." ${ }^{67}$ By 2010, it was determined that there would be no way to recover even the minimal cost of operations. Combine this with slow sales and a fiscal crisis - and the result is a failed experiment. Rice shut down its all digital press in the fall of $2010{ }^{68}$ However, the decision was not without its detractors.

One of the board members - who wished to remain anonymouscommented that new models of academic publishing are not going to be derived from a sales model. "We're moving to a different era of scholarly communication where it's more accessible to more people, and where we don't have to worry about commercial viability," said the anonymous board member. Scholarly publishing is being killed by placing emphasis on commercial viability - "there is no commercial viability," added the board member. ${ }^{69}$ No matter what the form and how diligent the work, a university press requires resources. Just as it takes resources to run a successful athletic program, so too does it take an investment to run a university press. And comparatively speaking, the costs are negligible: an editor makes less at Mizzou than an athletic trainer, and even the assistant baseball coaches make more than the press director.

Perhaps the solution is not to compare athletic salaries to press salaries but to treat university presses on the same level as athletic programs. Both are auxiliary operations subsidized by the university, and both play an important role in American letters. Perhaps we need to measure the scholarly impact of the books published by the press in the same way we measure the impact of the gymnastics or baseball team winning a game or their division. Or think of the cultural capital and prestige generated by the press as akin to the bowl victories or NCAA titles. And just as we don't scrap athletics if one of our teams loses games or money, we shouldn't scrap university presses if they don't generate enough revenue to cover their operation. While it may not be the most popular decision for the University of California Press to take one type of book off of their list, if it makes their press more viable in some way, it is akin to downsizing or closing down a sport to make an athletics program stronger. Think of the $\$ 200,000$ invested by Rice or the $\$ 400,000$ at Mizzou as the cost of being a strong university - a cost that in the big picture is most likely a fraction of the cost of one athletic coach. 
What does it mean when a university press fails? It means not that its authors are not successful or that its press was not run well. Rather it means that its university has abandoned part of its academic or scholarly mission: namely, supporting the publication of books that are the warp and woof of academic culture and democratic culture.

\section{Conclusion}

So, can neoliberalism in publishing get any worse? Is it possible that the publishing industry will soon mirror the auto and steel industries? Would a Big Three Book-Maker industry be good for authors and readers? The spate of recent mergers and acquistions like the one between Penguin and Random House indicate that we won't have to wait very long to find out.

To be sure, the path for the world's largest book publishers will continue to be bigger and bolder mergers. And soon, the publishing industry will probably need to be renamed the "infotainment" industry when suitors like Walt Disney and Time Warner come knocking. This is publishing in the age of neoliberalism. Again, a world, in the words of Pierre Bourdieu, with "no other law than that of maximum profit." It is "unfettered capitalism without any disguise," writes Bourdieu, "a very smart and very modern repackaging of the oldest ideas of the oldest capitalist."

Though Makinson, the new chairman of Penguin Random House, may try to make the case that this extreme concentration of publishing capital is going to benefit "creative and editorial independence," and will allow them "to take risks with new authors," don't believe it. It will be about as much risk as the market analysis of radical capitalism allowswhich won't be much. I'm certain that a William Gaddis or Djuna Barnes would not get very far in the world of neoliberal publishing risk.

That being said, the rise of a corporate publishing monopoly opens a huge opportunity both for acts of aesthetic resistance by the small and digital publishing worlds. As the larger presses become more monolithic, homogenized and profit-driven, the smaller presses can thrive as sites of aesthetic and editorial heterogeneity. And direct access to digital distribution systems such as Amazon and recognition networks such as Facebook provide unprecedented support and visibility to publications that might have otherwise gone unseen in warehouses or small press catalogues. Let 
the Penguins of the world continue their march toward monopoly. In the end, however, it is most likely a march toward extinction-and a boon for small press publishing.

The missteps and failures of the neoliberal publishing regime are reasons to be hopeful that there will be a backlash to McPublishing. There is also a hopeful coda to the University of Missouri Press saga: public outcry over the announcement of the closing of the press resulted in a stay of execution for that press. ${ }^{70}$ So there is hope that thoughtful critical resistance can result in a reversal-or at least a reprieve-in neoliberal decision-making in the publishing world.

In the end, it may be the acts of resistance of writers, teachers, and readers that determine the fate of neoliberal publishing. If teachers, for example, refuse to utilize the overly priced textbooks of corporate publishers that are re-released every two years in a new edition, this could help derail a very profitable aspect of the publishing industry; if writers, for example, choose to publish their work with small presses rather than corporate presses, this can help cut off the supply of their creative supply chain; if people vociferously refuse to accept the closure of university presses, this can perhaps change the behavior of neoliberal administrative decisions; and so on. The story of the growth of neoliberalism in publishing can become one of rise and fall more quickly if and only if we refuse to regard the fruits of our creative labors as commodities. This can be accomplished one author at a time through the choices we make relative to the intersection of our creative interests and our publishing needs. ${ }^{71}$

\section{Works Cited}

Alter, Alexandra. “Your E-Book is Reading You.” Wall Street Journal (29 June 2012).

Bosman, Julie and Michael J. De La Merced. “Borders Files for Bankruptcy.” New York Times (16 February 2011). http://dealbook.nytimes.com/2011/02/16/ borders-files-for-bankruptcy/

Bourdieu, Pierre. Acts of Resistance: Against the New Myths of Our Time. Trans. Richard Nice. Cambridge: Polity Press, 2000.

Cerf, Bennett. At Random: The Reminiscences of Bennett Cerf [1977]. New York: Random House, 2002. 
Di Leo, Jeffrey R. Corporate Humanities in Higher Education: Moving Beyond the Neoliberal Academy. New York: Palgrave MacMillan, 2013.

Dohle, Markus. “Letter from Markus Dohle to Random House Colleagues.” October 29, 2012. http://randomnotes.randomhouse.com/tag/markus-dohle/

Frazier, Charles. Cold Mountain. New York: Atlantic Monthly Press, 1997.

Giroux, Henry. The Terror of Neoliberalism: Authoritarianism and the Eclipse of Democracy. Boulder and London: Paradigm Publishers, 2004.

“Global Publishing Leaders 2012: Pearson Plc.” Publisher's Weekly (2 June 2012). http://www.publishersweekly.com/pw/by-topic/industry-news/financialreporting/article/52725-global-publishing-leaders-2012-pearson-plc.html

Hepburn, James. The Author's Empty Purse and the Rise of the Literary Agent. London: Oxford University Press, 1968.

Howard, Jennifer. "After Outcry Over Closure, U. of Missouri Press is Back to Printing Books." Chronicle of Higher Education (28 August 2012). http:// chronicle.com/article/After-Outcry-Over-Closure-U/133988/?cid=at\&utm _ source $=$ at\&utm_medium $=$ en

Jaschik, Scott. “Abandoning an Experiment.” Inside Higher Ed (20 August 2010). http://www.insidehighered.com/news/2010/08/20/rice

—. "SMU Suspends Its University Press.” Inside Higher Ed (7 May 2010). http: / www.insidehighered.com/news/2010/05/07/smu

Kellogg, Carolyn. "Facing Cutbacks, UC Press will Suspend Poetry Series." Los Angeles Times. (19 July 2011). http://latimesblogs.latimes.com/ jacketcopy/2011/07/uc-press-poetry-series.html

- "University of Missouri Press to Close After 54 Years." Los Angeles Times (24 May 2012). http://latimesblogs.latimes.com/jacketcopy/2012/05/university-ofmissouri-press-to-close-after-54-years.html

Kirch, Claire. "Outrage Grows to University of Missouri Shutting Down Press.” Publishers Weekly (28 May 2012). http://www.publishersweekly.com/pw/ by-topic/industry-news/publisher-news/article/52140-outrage-grows-touniversity-of-missouri-shutting-down-press.html

Makinson, John. "Letter of John Makinson to the Penguin Group (global).” October 29, 2012. http://www.publishersweekly.com/pw/by-topic/industry-news/ publisher-news/article/54538-makinson-s-letter-on-penguin-random-housemerger.html 
Palosaari, Ben. "University of Missouri Press Will Close." The Pitch News (24 May 2012). http://www.pitch.com/plog/archives/2012/05/24/ university-of-missouri-press-will-close

Saad-Filho, Alfredo and Deborah Johnston, eds. Neoliberalism: A Critical Reader. London: Pluto Press, 2005.

Silvey, Janese. "Wolf explains UM Press decision, says model sought.” Columbia Daily Tribune (1 June 2012).

Sweney, Mark. "Penguin and Random House Merger to Create Biggest Book Publisher Ever Seen.” The Guardian (29 October 2012). http://www.guardian. co.uk/books/2012/oct/29/penguin-random-house-book-publisher

“The Global 50: The World's Largest Book Publishers, 2012,” Publisher's Weekly (25 June 2012). http://www.publishersweekly.com/pw/by-topic/industry-news/ financial-reporting/article/52677-the-world-s-54-largest-book-publishers-2012. html

Thompson, John B. Books in the Digital Age: The Transformation of Academic and Higher Education Publishing in Britain and the United States. Cambridge: Polity, 2005.

-. Merchants of Culture: The Publishing Business in the Twenty-First Century, Second Edition. New York: Plume, 2012.

"University of Missouri Coaches, Employee Pay." [Formerly http://www.stltoday. com/news/local/education/university-of-missouri-coaches-employee-pay/ html_c0f4c842-6760-11df-979e-0017a4a78c22.html]

"University of Scranton Press is Closing." Inside Higher Ed (16 August 2010). http:// www.insidehighered.com/quicktakes/2010/08/16/u-scranton-press-closing

Windwalker, Stephen. “Amazon Positioned for 50\% Overall Market Share by End of 2012.” Seeking Alpha (3 February 2011). http://seekingalpha.com/ article/250507-amazon-positioned-for-50-overall-market-share-by-end-of-2012.

\section{Notes}

1. The two best sources on the role of the market in publishing are John B. Thompson's Books in the Digital Age: The Transformation of Academic and Higher Education Publishing in Britain and the United States (Cambridge: Polity, 2005) and his Merchants of Culture: The Publishing Business in the Twenty-First Century, Second Edition (New York: Plume, 2012). However, the association of neoliberalism with publishing has not to date been developed. 
2. See Thompson, “The Rise of Literary Agents,” Merchants of Culture, p. 59-100. See also, James Hepburn, The Author's Empty Purse and the Rise of the Literary Agent (London: Oxford University Press, 1968) for a longer range survey of literary agents.

3. Alfredo Saad-Filho and Deborah Johnston, "Introduction," Neoliberalism: A Critical Reader, Alfredo Saad-Filho and Deborah Johnston, eds. (London: Pluto Press, 2005), p. 1.

4. For Cerf's account of the acquisition of Ulysses, see Bennett Cerf, At Random: The Reminiscences of Bennett Cerf (New York: Random House, 2002), p. 90-98. Cerf's reminiscences were first published in 1977.

5. Number of publishers in the Bowker database with active ISBNs. John B. Thompson, Merchants of Culture, p. 153.

6. John B. Thompson, Merchants of Culture, p. 153.

7. John B. Thompson, "Table 6-The 12 Largest Trade Publishers in the US, 2007-2008" in Merchants of Culture, p. 117.

8. Random House trade and mass market revenues for 2007 were almost 2.4 billion dollars; the combined revenues of the 58,732 "small" presses, that is, presses under 1 million dollars annual sales, was around 2.7 billion dollars. See John B. Thompson, Merchants of Culture, p. 117, 153.

9. Bennett Cerf, At Random, p. 276.

10. Ibid., p. 276.

11. Ibid., p. 278.

12. Ibid., p. 278.

13. Ibid., p. 279.

14. Ibid., p. 282.

15. Ibid., p. 285.

16. Ibid., p. 285.

17. John B. Thompson, Merchants of Culture, p. 113.

18. John B. Thompson, “Appendix 1-Selected Imprints of the Main Publishing Corporations" in Merchants of Culture, p. 410-411.

19. Pierre Bourdieu, Acts of Resistance: Against the New Myths of Our Time, Trans. Richard Nice (Cambridge: Polity Press, 1998; reprint, 2000), p. 35.

20. "Random House" and "Penguin" together will consist of over 100 imprints, divisions, and groups in the US and UK alone. See John B. Thompson, "Appendix 1-Selected Imprints of the Main Publishing Corporations" in Merchants of Culture, p. 410-411, for a listing of them. 
21. Mark Sweney, "Penguin and Random House Merger to Create Biggest Book Publisher Ever Seen," The Guardian (29 October 2012). http://www.guardian. co.uk/books/2012/oct/29/penguin-random-house-book-publisher

22. “Global Publishing Leaders 2012: Pearson Plc.” Publisher's Weekly (2 June 2012). http://www.publishersweekly.com/pw/by-topic/industry-news/ financial-reporting/article/52725-global-publishing-leaders-2012pearson-plc.html

23. “The Global 50: The World's Largest Book Publishers, 2012," Publisher's Weekly (25 June 2012). http://www.publishersweekly.com/pw/by-topic/ industry-news/financial-reporting/article/52677-the-world-s-54-largestbook-publishers-2012.html

24. “Table 8-Estimated Number of Active Publishers in US by size, 2004,” John B. Thompson, Merchants of Culture, p. 153.

25. “Letter from Markus Dohle to Random House Colleagues.” October 29, 2012. http://randomnotes.randomhouse.com/tag/markus-dohle/

26. Ibid.

27. “Letter of John Makinson to the Penguin Group (global).” October 29, 2012. http://www.publishersweekly.com/pw/by-topic/industry-news/ publisher-news/article/54538-makinson-s-letter-on-penguin-randomhouse-merger.html

28. Mark Sweney, "Penguin and Random House Merger to Create Biggest Book Publisher Ever Seen"

29. Stephen Windwalker, "Amazon Positioned for 50\% Overall Market Share by End of 2012," Seeking Alpha (3 February 2011). http://seekingalpha. com/article/250507-amazon-positioned-for-50-overall-market-shareby-end-of-2012.

30. Pierre Bourdieu, Acts of Resistance: Against the New Myths of Our Time, p. 34, 35.

31. Henry Giroux, The Terror of Neoliberalism: Authoritarianism and the Eclipse of Democracy (Boulder and London: Paradigm Publishers, 2004), p. xxii.

32. There are 58,795 active publishers in the US with annual sales revenue of less than one million dollars. John B. Thompson, "Table 8-Estimated Number of Active Publishers in the US by size, 2004” in Merchants of Culture, p. 153.

33. Bourdieu, Acts of Resistance, p. 35.

34. See Alexandra Alter, "Your E-Book is Reading You.” Wall Street Journal (29 June 2012).

35. “Table 8-Estimated Number of Active Publishers in US by size, 2004,” John B. Thompson, Merchants of Culture, p. 153. 
36. Charles Frazier, Cold Mountain (New York: Atlantic Monthly Press, 1997), p. 1.

37. John B. Thompson, Merchants of Culture, p. 178.

38. The first novel was Charles Frazier's Cold Mountain. His follow-up novel, Thirteen Moons, did not even cover the initial advance, let alone the actual \$8.25 million dollar advance. See John B. Thompson, Merchants of Culture, p. 178.

39. John B. Thompson, "Table 8-Estimated Number of Active Publishers in the US by size, 2004" in Merchants of Culture, p. 153.

40. John B. Thompson, "Table 6-The 12 Largest Trade Publishers in the US, 2007-2008" in Merchants of Culture, p. 117.

41. John B. Thompson, Merchants of Culture, p. 31-32.

42. “Table 3-Estimated Shares of US Book Retail Market, 2006.” John B. Thompson, Merchants of Culture, p. 50.

43. John B. Thompson, Merchants of Culture, p. 28.

44. Ibid., p. 26.

45. “Table 1-The Expansion of Borders and Barnes \& Noble, 193-1994,” John B. Thompson, Merchants of Culture, p. 30.

46. John B. Thompson, Merchants of Culture, p. 29-30.

47. Julie Bosman and Michael J. De La Merced, "Borders Files for Bankruptcy," New York Times (16 February 2011). http://dealbook.nytimes. com/2011/02/16/borders-files-for-bankruptcy/

48. The American Association of University Presses reports just over 130 members. http://www.aaupnet.org/

49. Ben Palosaari, "University of Missouri Press Will Close.” The Pitch News (24 May 2012). http://www.pitch.com/plog/archives/2012/05/24/ university-of-missouri-press-will-close

50. http://press.umsystem.edu/\%28S\%28wm1t4d55lz2yogenbmptcjfi\%29\%29/ catalog/CategoryInfo.aspx?cid=152\&AspxAutoDetectCookieSupport=1

51. Stuckey is leading a charge to save the press. Claire Kirch, "Outrage Grows to University of Missouri Shutting Down Press,” Publishers Weekly (28 May 2012). http://www.publishersweekly.com/pw/by-topic/industry-news/ publisher-news/article/52140-outrage-grows-to-university-of-missourishutting-down-press.html

52. Janese Silvey, "Wolf explains UM Press decision, says model sought," Columbia Daily Tribune (1 June 2012).

53. "University of Missouri Coaches, Employee Pay." [Formerly http://www.stltoday.com/news/local/education/ 
university-of-missouri-coaches-employee-pay/html_c0f4c842-6760-11df979e-0017a4a78c22.html]

54. MU Salary Database 2011. https://www.google.com/fusiontables/ DataSource?snapid $=$ S456793mZOi

55. Ibid.

56. Ben Palosaari, "University of Missouri Press will close," (op cit).

57. Carolyn Kellogg, "University of Missouri Press to Close After 54 Years." Los Angeles Times (24 May 2012). http://latimesblogs.latimes. com/jacketcopy/2012/05/university-of-missouri-press-to-close-after54-years.html

58. "University of Missouri Coaches, Employee Pay," (op cit)

59. Carolyn Kellogg, "University of Missouri Press to close, after 54 years," (op cit).

60. Scott Jaschik, "SMU Suspends Its University Press," Inside Higher Ed (7 May 2010). http://www.insidehighered.com/news/2010/05/07/smu

61. "University of Scranton Press is Closing." Inside Higher Ed (16 August 2010). http://www.insidehighered.com/ quicktakes/2010/08/16/u-scranton-press-closing

62. Carolyn Kellogg, "Facing Cutbacks, UC Press will Suspend Poetry Series. Los Angeles Times. (19 July 2011). http://latimesblogs.latimes.com/ jacketcopy/2011/07/uc-press-poetry-series.html

63. Janese Silvey "Wolf explains UM Press decision, says model sought," (op cit).

64. Ibid.

65. Ibid.

66. Scott Jaschik, "Abandoning an Experiment." Inside Higher Ed (20 August 2010). http://www.insidehighered.com/news/2010/08/20/rice

67. Ibid.

68. Ibid.

69. Ibid.

70. Jennifer Howard, "After Outcry Over Closure, U. of Missouri Press is Back to Printing Books," Chronicle of Higher Education (28 August 2012). http:// chronicle.com/article/After-Outcry-Over-Closure-U/133988/?cid=at\&utm source $=$ at\&utm_medium $=$ en

71. An earlier and briefer version of this chapter may be found in my book, Corporate Humanities in Higher Education: Moving Beyond the Neoliberal Academy (New York: Palgrave MacMillan, 2013), 105-119. 


\section{Chapter 9}

\section{The Post-Political Turn \\ Theory in the Neoliberal Academy}

Christopher Breu

Neoliberalism has cast a long shadow over the US academy. Mirroring the flexibility championed by the economic ideology, neoliberalism's impact on the academy in the last thirty years has taken a number of different forms and provoked a number of different responses. In the field of literary and cultural studies, these responses have taken forms both material and ideological, from the growth of non-tenure track labor, the reduction of tenure line positions, the emergence and then attenuation of the academic star system, the destruction of employee benefits, the rationalization of teaching based on FTEs (or faculty time equivalents), the preoccupation with conceptions of subjectivity and culture that are flexible and in continuous transformation, and the growth and then partial retreat of politicized scholarship, including scholarship that takes neoliberalism itself as an object of critique.

While each of these areas of neoliberalism's influence deserves analysis, and indeed have been analyzed by a range of different scholars, including the other contributors to this volume, in what follows I want to take up the last: the growth and partial retreat of politicized scholarship in the academy. The transformation of academic theory over the past thirty years is one way to chart this political movement and its relationship to neoliberalism. The responses to neoliberalism in academic theory have ranged from the conscious to the unconscious, the symptomatic to the quietistic, and the resistant to the compliant. Indeed, the theoretical 
responses have been almost as varied as the ideological and material transformations produced by neoliberalism itself.

In what follows, then, I want to trace a certain dominant trajectory of contemporary theory from the politicization of culture and language in what Philip Wegner terms the "long nineties" to the potential depoliticization emerging in our own present moment. ${ }^{1}$ In contrast to this worrying de-politicizing trend, I will posit the hopeful emergence of counter-trend of newly materialist scholarship that takes up the political engagements of the long nineties, but in a more materialist direction that holds the potential to challenge the dematerializing ideology of neoliberalism itself, with its emphasis on financialization and what Michael Hardt and Antonio Negri term "biopolitical" or so-called "immaterial" labor (i.e. affect, service, and intellectual labor). ${ }^{2}$ Thus, the signifier "postpolitical" in this paper has an ambiguous valence: it can either describe a retreat from politics altogether or the possibility of a materialist theoretical politics that moves beyond the largely cultural politics of the long nineties.

Before developing this argument further, however, I should provide a quick account of how I am conceptualizing neoliberalism. My account of neoliberalism is influenced equally by Michel Foucault's The Birth of Biopolitics and David Harvey's A Brief History of Neoliberalism. Foucault's prescient genealogy of neoliberalism, delivered as series of lectures in 1978 and 1979 and posthumously published in 2004, traces its emergence out of German "ordoliberalism" in the immediate postwar moment. ${ }^{3}$ In his account, neoliberalism represents the most recent manifestation of what he calls biopolitics, or the political-economic management of "man-as-species," consisting in "making live and letting die."4 This power emerges alongside political liberalism in the nineteenth century as a form of what Foucault terms governmentality, but it is transformed within the workings of neoliberalism, such that the market, rather than political governmentality, becomes the privileged domain of measuring and regulating human worth. Central to this new calculus of human worth is the category of "human capital," which quantifies and rationalizes all human activities and human life itself. ${ }^{5}$

If Foucault charts the long trajectory of the political economic transformations that lead to neoliberalism and its calculus of human worth, 
Harvey's account emphasizes neoliberalism as a conscious and classinflected ideological and political-economic project in the present. This project has had two aims: to reorganize contemporary capitalism, "by liberating individual entrepreneurial freedoms and skills within an institutional framework characterized by strong private property rights, [and what are imagined to be] free markets, and free trade"; and to "re-establish the conditions for capital accumulation and to restore the power of economic elites." ${ }^{\prime 6}$ Central to this second goal is the dynamic of what Harvey, reworking Marx's account of primitive accumulation, calls "accumulation by dispossession," or the appropriation of various forms public, private, and commonly held wealth by corporations and economic elites. Thus neoliberal accumulation not only works through wage suppression via the so-called freeing up of markets but also by the wholesale appropriation of wealth via privatization of public goods and services, of what Antonio Negri and Michael Hardt call the "common" (or wealth that is collectively and directly owned, outside of the reach of both the state and corporations), and by redefining waged work as unwaged work. ${ }^{8}$ Drawing on both Foucault's and Harvey's account enables me to theorize neoliberalism as both a subjectifying, social calculus on one hand, and an ideological and political-economic project on the other.

\section{Academic Knowledge in the Neoliberal Present}

These neoliberal dynamics have taken on a specific form in the US academy. For those humanists and social scientists who experienced the relative privilege of tenure, the key enemy in the long 90s appeared to be neoconservatism rather than neoliberalism. The wars were primarily cultural, and the struggle was around the content of knowledge within and against various disciplines, rather than the political-economic organization of higher education itself. As Marc Bousquet has demonstrated, for the growing academic proletariat (the ever growing ranks of adjunct professors), the material war being waged on the public university by neoliberalism was evident much earlier than it was for those of us who have been sheltered by the relative protections of tenure and tenure-line positions. ${ }^{9}$ It has only been with what I want to call the second phase of neoliberalism in the last ten or so years (a phase in which the dynamics 
of accumulation by dispossession function not only by the privatizing of public jobs and public services but even more by the destruction of wagelabor and the concomitant growth of unwaged work) that it is clear to all but the most privileged actors that the basic threat to academic work is not cultural but economic. And yet, we let the cultural be thoroughly subordinated to the economic only at our peril. While we need to resist the economic on its own terms, we also need to hold out for the partial autonomy of the cultural and the scholarly, if only to maintain a cultural, intellectual, and scholarly position from which to not only critique the present but also to imagine and begin the work of constructing a different economic and cultural future.

Before attending to the way in which the notion of political scholarship has changed and been partially replaced by what I am calling postpolitical scholarship in this second phase of neoliberalism, I want to quickly define the major features of the neoliberal university in the present. These are: 1) the war against university professors and tenure itself as part of the more general war against teachers (this war has both cultural dimensions, such as right-wing populism that mixes anti-intellectualism with a worship of so-called market solutions, and directly economic ones, such as the destruction of employee benefits and protections, like the ones we are experiencing right now in Illinois); 2) the redefinition of the public university system as a whole along the lines of skills training and uncritical vocationalism (as opposed to a critical or workerist vocationalism), which goes hand-in-hand with the redefinition of teachers as customer-service workers; 3 ) the redefinition of the work of scholarship as unpaid labor that is owned by the university and by various corporations or, alternately, as the generation of free content for the work speed up produced by what Jodi Dean describes as "communicative capitalism"; 4) The casualization of the labor force as part of a more general drive towards casualization, unwaged labor, and the complete blurring of the lines (and not in a utopian way) of labor and leisure. ${ }^{10}$

\section{Cultural Politics in the Long Nineties}

Now that I have briefly discussed neoliberalism and its impact on the academy, I am in a place to chart the transformations of politically-engaged 
theory and its relationship to neoliberalism in the humanities and social sciences in the last thirty years. Politics, and its closely related cognate, the political, have been central signifiers within theoretical work done in the last thirty or so years in the academy. In the heyday of the culture wars of the 1980s and 1990s, the signifier "political" often represented a shorthand for the kind of engaged scholarship and academic activism that was central to struggles around canons and cultures that characterized the era. Christopher Connery argues, in his Introduction to The Worlding Project, that this was a moment marked by the canon wars, the advent of postcolonial criticism, and the emergence of cultural studies in the US. He asserts that cultural studies in particular inflected the specific manifestation of the political central to academic work in the 80s and 90s: "In its US incarnation, Cultural Studies represented the political turn, but eclectically: it included the turn to popular culture and identity politics of various kind and was, as Jameson suggested, a 'desire' more than a field." ${ }^{11}$ The Worlding Project itself, edited by Connery and Rob Wilson, feels like a late and compelling expression of this political turn, combining a cultural studies attention to popular cultures and political movements with a more recent engagement with globalization and transnationalism.

The specific meaning of the signifier, political, in the moment of the political turn enabled a lot of important work to be undertaken in the academy, not the least of all was the hard-won notion that all scholarship is indeed political (whether consciously or unconsciously so) and that the engaged or activist scholar should be conscious of the political import and effects of her work. As a product of the literature program at UCSC that produced The Worlding Project, with its emphasis on world literature and cultural studies, the kinds of work undertaken by the authors in the volume hold special places in my heart and my scholarship. Much of my own work is informed by the kinds of politicized cultural analysis enabled by the political turn. If what Connery names the political turn is one designation for the fusion of culture and politics that reached, perhaps its apex in the mid-nineties, other names for it are what Fredric Jameson's has deemed the cultural turn, what Richard Rorty designated the linguistic turn, and what Jameson, along with many others, has also termed postmodernism. ${ }^{12}$ 
While each of these designations carry slightly different resonances, and emphasize different aspects of the work of theory and scholarship, together they suggest the parameters of engaged scholarship in the long nineties. This was scholarship that privileged culture and language as key terrains of political struggle. Even the Marxism of this moment advanced an understanding of the economic as newly cultural and semiotic, arguing that, in Jameson's words, the base and superstructure "collapse back into each other." ${ }^{13}$ Central to this moment was the practice of critique, for even as Adorno was often dismissed by cultural studies practitioners for his elitism, a version of his practice of critique, as necessarily separate from praxis, became the default mode for cultural criticism.

The work enabled by the political turn was both valuable and necessary. Indeed, much of this work, when not disenabled by neoliberal pressures within the current academy, continues to do vital work in the present. In terms of the politics of subjectivity, signification, and representation, such forms of cultural critique are indispensable. Yet, as this description suggests, the political turn of the 1990s had limitations as well as advantages. As Marxist critics of postmodernism such as Jameson and Harvey as well as well as new materialists such as Diana Coole, Samantha Frost, and Levi Bryant have pointed out, the politics of the long nineties was often confined to or at least imagined through the frames of culture and language. ${ }^{14}$ This emphasis on culture and language as exclusive spaces of political and social struggle disenabled all forms of materialist politics and even materialist inquiry other than the weak materialisms represented by cultural materialism and the materiality of the signifier. Thus, for work that wanted to explore the material dimensions of ecosystems, political economy or the political shaping of biological life itself, the version of politics enshrined by the political turn was as constraining as it was liberating. Indeed, the cultural turn itself, can be read as a symptom of the first phase of neoliberalism in two distinct ways: 1) the emphasis on language as constructive echoes the turn towards financial speculation as a seemingly parthenogenetic form of wealth generation; 2) the malleability of subjectivity celebrated by social construction, as Harvey notes, echoes the flexibility of just-in-time production practices in post-Fordist neoliberalism. ${ }^{15}$ 
Still, in situating the epicenter of this cultural version of political work in the long 90s, I do not want to unintentionally participate in the very process of depoliticization that this essay critiques. As we know from the forms of knowledge enabled by the political turn, descriptive histories, like all narratives, can become subtly prescriptive, enforcing the very dynamics they mean to critique. Yet, as the twin legacies of Marxist and Foucauldian thought teach us, there can be no effective politics or political struggle without a careful attention to the material and discursive circumstances in which we find ourselves thinking, working, and acting. Thus, the history I offer in this paper is meant to trace historical tendencies rather than absolutes, and attend not only to the attenuation of certain formations or possibilities but also the opening up of others. Moreover, to resist the logic of neoliberalism, which began in the moment of the political turn but has become ever more pervasive and violent in our so-called age of austerity (i.e. abundance for the rich and austerity for everyone else), the point is not to celebrate each new theoretical or academic development as an epochal shift that renders what came before so much used up human capital. Such a commodified view of knowledge is one of the dangers of the recent language of "turns" if not used carefully. Indeed, the proliferation of the very language of turns (the turn turn if you will!) may be one symptom of academic production under the second phase of neoliberalism and communicative capitalism. Given the pressures of instant communication and the ever more immediate obsolescence of commodities under communicative capitalism, it is not surprising to find academia itself becoming part of the general speedup that dictates the movement of life in the present. Rather than surrendering to the logic of this speed up, we need to preserve what was best from earlier moments even as we attend to the transformed situation and possibilities of the present.

\section{The Post-Political Turn in the Present}

The most immediate intellectual symptom of the full-scale neoliberal assault on the academy is the turn away from political work (especially the cultural version of politics that I described earlier). This turning away from the political has both negative and potentially positive valences. 
Much of how we interpret the turn away from the political hinges, of course, on how we define the political itself. Taking the broad definition of politics as encompassing all political work, and not just the understanding of cultural politics enshrined in the long nineties, the turn away from politics can only be interpreted dispiritingly as a negative effect of the second phase of neoliberalism in the academy.

Such a negative version of the post-political turn (what might more accurately be called the "apolitical turn") is evident everywhere in contemporary scholarship, from Stephan Ramsay's mantra that the digital humanities "involves moving from reading and critiquing to building and making," through the invocation of a scholarship of "wonder" as an antidote to critique advocated by object-oriented ontologist Ian Bogost, to the wholesale substitution of the concept of the ethical for the political and the ecological for the economic in a range of recent scholarship. ${ }^{16}$ All of these theoretical moves, as dialectical correctives, have something to recommend them. Indeed, as Bruno Latour has argued in his ambiguous piece of the same name, "critique has run out of steam," at least as an isolated and non-dialectical practice. ${ }^{17}$ Moreover, it is important to engage the ethics upon which our political commitments are grounded, even as the category of the ethical as a discourse has to be interrogated, in turn, by the political with its attention to power, exploitation, and inequality. Similarly, academic theory, for too much of its history, has remained disengaged from the ecological, even as what Latour and Jane Bennett term "political ecology" has to be understood as distinct yet intertwined with political economy, if we are to provide effective accounts of the violence of ecological degradation and economic exploitation. ${ }^{18}$

Yet the versions of this "post-political" work being advocated by writers such as Ramsay and Bogost rarely see themselves in such dialectical terms. Bogost's chapter, entitled "Wonder, from Alien Phenomenology, is perhaps the most symptomatic version of the apolitical turn, with its account of how the Food Network's Ace of Cakes, which chronicles the production of specialty cakes for folks who can drop a hundred grand on a cake, manifests more satisfying materialism than HBO's celebrated chronicle of the class and race stratified United States, The Wire. ${ }^{19}$ This version of Bogost's scholarship thus represents one of the dangers of the explosion of posthumanist scholarship in the present. If the promise of 
posthumanism is an expanded conception of the political, one that, in Latour's account and in the account of more political OOO scholars such as Bryant, takes into consideration nonhuman as well as human actors, then the danger it represents is a symptomatic turning away from the human altogether as a way of warding off any reckoning with the degradation of human possibility and knowledge under neoliberalism. If the work of Bogost and some other posthumanists seems like a defensive formation in relationship to the neoliberal assault on the academy, the work of some digital humanities seems, typically, much more affirmatively neoliberal. Indeed, the shift from critique to making and building (rather than a dialectical or even discontinuous emphasis on both as they challenge and transform each other) feels very much like the shift that the forces of neoliberalism are asking the humanities as a whole to make: no more preoccupation with citizenship (global or otherwise), critical thought, or imagining a different social or economic order; we need to just make and do. Knowledge should be purely applied rather than mixing the applied with the theoretical and speculative.

If such an "apolitical turn" threatens to replace the cultural version of political scholarship that was central to the long 90s (even as the latter work continues, though, in less prestigious and more embattled ways), the signifier, political, has interestingly begun to migrate into a more specific usage, one associated with another body of theory and scholarship that has gained interdisciplinary prominence in the new century: this is the work associated with theories of "the political." Spearheaded by the return to prominence of political theory in philosophical thought in the last twenty years, from the revaluation of older theorists like Hannah Arendt and (most ambiguously) Carl Schmidt through the emphasis on the political in theories of biopower and the biopolitical proffered by Giorgio Agamben, Roberto Esposito, and the posthumous Foucault, the international prominence the version of Deleuzian Marxism associated with Antonio Negri and Michael Hardt, Franco Berardi and and Maurizio Lazzarato as well as to the new work done under the signifier of communism by Alain Badiou, Slavoj Žizek, Jodi Dean, and Bruno Bosteels, this newer deployment of the political emphasizes a philosophical approach to matters political, often moving beyond specific political programs to inquire about the very constitution of the political itself. ${ }^{20}$ 
Bosteels describes the "'return of the political' in European philosophy in the last few decades" in the following way: "Precisely what is at stake $\ldots$ is the very question of the relation between politics and philosophy, which is but one instance among others of the relations between the real and the thought of the real." 21 Thus, the turn to the political is less about immediate political struggle and more about theorizing the conditions under which philosophy can be adequate to the political present. The work primarily takes the form of a meta-theoretical speculation on the possibility of a political philosophy itself. Still, to the degree that such a "thought of the real" takes the material force of the real (I'm assuming here that the usage of the signifier in this case is not strictly Lacanian) as its site of engagement it holds real promise as well.

To broadly and problematically generalize about writers who are very distinctive in their approaches, this work, while perhaps representing the reduction of the signifier "political" to a specific field, holds advantages over the more culturalist understanding of politics that was central during the long 90s. These include: 1) an understanding of politics that extends beyond symbolic and cultural struggle and toward the politicaleconomic transformation of global society as such; 2) in the work of the theorists of biopolitics, an understanding of life itself as an object of theorization and political-economic intervention, one that, as I have already shown, can open out to a critical engagement with neoliberalism; 3) an affirmative (as well as critical) vision that moves beyond the paralysis that can be produced by pure critique and cultural relativism; 4) in the case of Dean and Hardt and Negri, an engagement with new forms of symbolic and affective labor and the way in which they betoken the return of accumulation by dispossession as a central dynamic of neoliberal capitalism.

Yet, while much of this work advances an important political vision and represents some of the political possibilities that open up as we move beyond the cultural and linguistic turns, too much of it is preoccupied almost exclusively with the categories of the subject and the political as severed from the material and the political-economic. Indeed, Badiou's work is particularly marked in this regard. His emancipatory vision, as articulated in The Communist Hypothesis and in his different essays in the two Idea of Communism collections, is organized largely around the twin categories of the Subject (understood as a category that "cannot be 
reduced to an individual") and the Idea (which Badiou defines as "an operative mediation between the real and symbolic"). ${ }^{22}$ Thus, Badiou's revolutionary vision (what Bruce Robbins' nicely calls his "millenarian Marxism," although I'm not sure how much Marxism there finally is in it) tends to privilege ideas (in an explicitly Platonic register) and the subject pole of the subject/object dialectic (“Balibarism!”). Indeed, Badiou's materialism, in contrast to his idealism which is everywhere central to his vision, is relegated primarily to the category of the State, which he defines in the present as being made up of "the capitalist economy, the constitutional form of government, the laws (in the judicial sense) concerning property and inheritance, the army, the police." ${ }^{23}$ Even Badiou's, most celebrated category, the "event" is more transfigurative than materialist. It is the counterfactual production of a "glorious body." 24

Badiou's collapsing of the economy into the state is telling. His vision thus emphasizes a largely political definition of both capitalism and communism, where the economy (and its relationship to various material ecologies) is a distant afterthought. For all of their differences, Hardt and Negri's accelerationist vision of the transformation of biopolitical capitalism into a communism of the multitude shares with Badiou this privileging of administrative forms, what they term "Empire," as the site of appropriation and oppression (I hesitate to say exploitation, since to my mind this is a concept tied to economics rather than politics). ${ }^{25}$ While Hardt and Negri's vision in other ways has much to recommend it, from the detailing of biopolitical capitalism and so-called immaterial production, to a much more thoroughly political-economic account of the development of the productive forces under neoliberalism, it is striking that their revolutionary vision is entirely focused on the dismantling of a political entity.

The question of the state is certainly a pressing one under neoliberalism and as it has become increasingly allied with the corporate and financial sectors over the past twenty years to form what Harvey describes as the "state-finance nexus" or "state-corporate nexus" in most places around the world. ${ }^{26}$ It makes sense in such a context to situate the state, and not just the economy, as a locus of struggle. Yet, the disdain of the state shared by both Badiou and Hardt and Negri (as well as by resurgent forms of anarchist theory in the present) can itself be read as a symptom 
of neoliberalism: in providing a radical critique of the state such theories unintentionally contribute to the neoliberal destruction of the social democratic state, the welfare state, and of other versions of statebased socialism.

\section{The Materialist Opening}

Given the subjectivist and idealist limits to much of this recent theorizing about the political, perhaps our post-political moment in the academy can be understood not exclusively as a closing-down or a silencing, but also as opening up a space for the possibility of a new kind of materialist work, one not entirely circumscribed by the linguistic, and the cultural, and, indeed, the political as conceptual place holders. While, these categories are crucial and indeed we need to continue to fight for their validity for any socially committed scholarship, they have also done as much to circumscribe scholarship as enable it in the past thirty years.

This at least has been the argument advanced by a range of recent work in what Diana Coole and Samantha Frost term the "new materialisms," from the material feminism championed by Stacy Alaimo and Susan Hekman, to the object-oriented ontology of Levi Bryant and Graham Harman, the political ecology of Bruno Latour and Jane Bennett, the speculative materialism and realism championed by a range of new continental philosophers, work in affect studies by Lauren Berlant, Kathleen Stewart, and others, as well as ongoing work in political-economy by David Harvey, Immanuel Wallerstein, Aníbal Quijano, Saskia Sassen, and the theorists of economic production published in Another Production is Possible, edited by Boaventura de Souza Santos. ${ }^{27}$ While these writers are extremely diverse and share as many (if not more) disagreements as they do points of convergence, as well as, in the case of some of the speculative materialists and realists, a wavering commitment to politics, their shared commitment to materialism suggests the possibility for a new organizing principle for politically engaged theory in the present. Central to these different forms of materialism is a commitment to pushing beyond the limits of language and culture as placeholders for the social as such in order to engage the impact that ecological, political-economic, bodily, and object-based materialities on our ecologically and economically 
crisis-ridden present. Or as Coole and Frost put it: "We share the feeling current among many researchers that the dominant constructivist orientation to social analysis is adequate for thinking about matter, materiality and politics in ways that do justice to the contemporary context of biopolitics and global political economy." ${ }^{28}$ Such a materialism might help to counteract the ideology of dematerialization (what I elsewhere call avatar fetishism) that is one of the central logics of neoliberalism and communicative capitalism. ${ }^{29}$ A politics based around this new materialist opening would move beyond symbolic struggle and toward a politics that takes the insistence of the material itself as its political measure.

Thus, at its best, this new materialist work, when grounded in a careful attention to both political economy and political ecology, enables us to imagine the relationships among bodies, affects, subjects, objects, ecologies, and the world economy (as well as of course, among culture and language as in part different registers of the material) in ways that move past pure critique and toward a project of building a new political, economic, and ecological future. Thus, the emphasis in the digital humanities on building and making is not wrong, but it cannot be at the expense of critiquing and analyzing. These are different parts of a dialectic that are only separated from each other at the peril of the possibilities represented by both poles. Such a reactivated dialectic would not only take into consideration the way in which various materialities exceed, exist in tension with, and place limits on (as well as interpenetrate with) the domains of culture and language, but also refuse to turn the material turn into an argument for either a new vitalism or a new determinism. Such a reactivated dialectic would also take the depredations of neoliberalism in the academy as its first target, even as it also tries to imagine and enact alternate political and economic forms of praxis that move beyond the endgame of pure critique.

This political economic praxis might take some of the forms chronicled by Boaventura de Souza Santos in his innovative edited volume, Another Production is Possible, which examines new forms of labor internationalism, including forms of successful cooperative production in Portugal and India, the solidary economy in Brazil, and other alternative production systems. As de Souza Santos himself recognizes, these often local movements of counter-production need to be linked up to larger 
and more global transformations: "In such case, only the interconnection of local action and alternative strategies of incorporation or resistance at a regional, national, or global scale can save local initiatives faced with capitalist competition. ${ }^{30}$ It is here where the global political economy pioneered by world-systems economists such as Wallerstein, Quijano and Giovanni Arrighi, as well as social geographers such as Harvey become crucial. We need to think collectively and globally if we are really going to challenge the economic and ecological devastation of the present. It is towards such a collective vision that Badiou in his reactivation of the signifier communism is perhaps pointing, but I am less concerned with the signifiers around which such a collective vision might be oriented and more concerned with the political, social, and theoretical labor needed to produce real material economic, ecological, and social change on both local, regional and global levels.

Such, to me is the promise of the materialist opening in the present moment of theory. In order to make this materialist opening matter, we will have to build links between political economy and what Latour terms "political ecology" (even though Latour himself problematically wants to replace the former term with the latter), or the recognition of all actors in any given collective, human and nonhuman. We will also have to do the theoretical work of linking theories of matter to materialisms of the political economic and political ecological sort. This work is beyond the scope of this essay, but it is one of the genuinely progressive possibilities represented by the material turn. The materialist opening, then, is perhaps the moment of dialectical possibility within the otherwise dispiriting prospect of a truly post-political academy.

\section{Works Cited}

Alaimo, Stacy and Susan Hekman, eds., Material Feminisms. Bloomington: University of Indiana Press, 2008.

Badiou, Alain. The Communist Hypothesis. London: Verso, 2010.

- "The Communist Idea and the Question of Terror." The Idea of Communism 2:

The New York Conference. London: Verso, 2013.

- . "The Idea of Communism." The Idea of Communism. Costas Douzinas and Slavoj Žižek, eds. London: Verso, 2010. 
Bennett, Jane. Vibrant Matter: A Political Ecology of Things. Durham: Duke University Press, 2010.

Bogost, Ian. Alien Phenomenology or What It's Like to Be a Thing. Minneapolis: University of Minnesota Press, 2012.

Bosteels, Bruno. The Actuality of Communism. London: Verso, 2011.

Bousquet, Marc. How the University Works: Higher-Education and the Low-Wage Nation. New York: NYU Press, 2008.

Breu, Christopher. Insistence of the Material: Literature in the Age of Biopolitics. Minneapolis: University of Minnesota Press, 2014.

Bryant, Levi. The Democracy of Objects. Ann Arbor: Open Humanities, 2011.

-. Nick Srnicek, and Graham Harman, eds. The Speculative Turn: Continental Materialism and Realism. Melbourne: re.press, 2011.

Clough, Patricia Ticineto with Jean Halley, eds. The Affective Turn: Theorizing the Social. Durham: Duke University Press, 2007.

Connery, Christopher Leigh. "Introduction: Worlded Pedagogy in Santa Cruz." The Worlding Project: Doing Cultural Studies in the Era of Globalization. Rob Wilson and Christopher Leigh Connery, eds. Santa Cruz, CA: New Pacific Press, 2007, 1-11.

Coole, Diana and Samantha Frost. "Introducing the New Materialisms." New Materialisms: Ontology, Agency, and Politics. Diana Coole and Samantha Frost, eds. Durham: Duke University Press, 2010.

de Sousa Santos, Boaventura. "Introduction: Expanding the Economic Canon and Searching for Alternatives to Neoliberal Globalization." Another Production is Possible: Beyond the Capitalist Canon. Boaventura de Sousa Santos, ed. London: Verso, 2006.

Esposito, Roberto. Living Thought: The Origins and Actuality of Italian Philosophy. Trans. Zakiya Hanafi. Stanford: Stanford University Press, 2012.

Foucault, Michel. The Birth of Biopolitics: Lectures at the Collège de France, 1978-1979. Trans. Graham Burchell. New York: Picador, 2008.

—. "Society Must Be Defended": Lectures at the Collége de France, 1975-1976. Trans. David Macey. New York: Picador, 2003.

Gold, Matthew K. “The Digital Humanities Moment.” Debates in the Digital Humanities. Gold, Matthew K., ed. Minneapolis: University of Minnesota Press, 2012.

Gregg, Melissa and Gregory J. Seigworth, eds. The Affect Theory Reader. Durham: Duke University Press, 2010. 
Hardt, Michael and Antonio Negri. Commonwealth. Cambridge: Harvard University Press, 2008.

—. Empire. Cambridge: Harvard UP, 2000.

Harvey, David. A Brief History of Neoliberalism. Oxford: Oxford University Press, 2005.

-. The Condition of Postmodernity: An Enquiry into the Origins of Cultural Change. Oxford: Blackwell, 1990.

-. The Enigma of Capital and the Crises of Capitalism. Oxford: Oxford University Press, 2010.

Jameson, Fredric. The Cultural Turn: Selected Writings on the Postmodern, 1983-1998. London: Verso, 1998.

-. Postmodernism, or The Cultural Logic of Late Capitalism. Durham: Duke UP, 1991.

Latour, Bruno. Politics of Nature: How to Bring the Sciences into Democracy. Trans. Catherine Porter. Cambridge: Harvard UP, 2004.

- "Why Has Critique Run out of Steam? From Matters of Fact to Matters of Concern." Critical Inquiry 30 (Winter 2004): 225-248.

Noyes, Benjamin. The Persistence of the Negative: A Critique of Contemporary Continental Theory. Edinburgh: Edinburgh UP, 2012.

Rorty, Richard. The Linguistic Turn: Essays in Philosophical Method. Chicago: University of Chicago Press, 1992.

Wallerstein, Immanuel. World-Systems Analysis: An Introduction. Durham: Duke University Press, 2004.

Wegner, Philip. Life Between Two Deaths: US Culture in the Long Nineties. Durham: Duke UP, 2009.

\section{Notes}

1. Philip Wegner, Life Between Two Deaths: US Culture in the Long Nineties (Durham: Duke University Press, 2009), p. iii.

2. Michael Hardt and Antonio Negri, Empire (Cambridge: Harvard University Press, 2000), p. 28-29.

3. Michel Foucault, The Birth of Biopolitics: Lectures at the College de France, 19781979, Trans. Graham Burchell (New York: Picador, 2008), p. 103. 
4. Michel Foucault, "Society Must Be Defended": Lectures at the Collége de France, 1975-1976, Trans. David Macey (New York: Picador, 2003), p. 243, 247.

5. Michel Foucault, The Birth of Biopolitics, p. 226.

6. David Harvey, A Brief History of Neoliberalism (Oxford: Oxford University Press, 2005), p. 2, 19.

7. David Harvey, A Brief History of Neoliberalism, p. 178.

8. Michael Hardt and Antonio Negri, Commonwealth (Cambridge: Harvard University Press, 2008), p. viii.

9. Marc Bousquet, How the University Works: Higher-Education and the Low-Wage Nation (New York: NYU Press, 2008), p. 90-124.

10. Ibid., p. 120.

11. Christopher Leigh Connery, "Introduction: Worlded Pedagogy in Santa Cruz," The Worlding Project: Doing Cultural Studies in the Era of Globalization, Rob Wilson and Christopher Leigh Connery, eds. (Santa Cruz, CA: New Pacific Press, 2007), p. 1-11, p. 5.

12. See Fredric Jameson, The Cultural Turn: Selected Writings on the Postmodern, 1983-1998 (London: Verso, 1998); Fredric Jameson, Postmodernism, or The Cultural Logic of Late Capitalism (Durham: Duke University Press, 1991); Richard Rorty, The Linguistic Turn: Essays in Philosophical Method (Chicago: University of Chicago Press, 1992).

13. Fredric Jameson, Postmodernism, or The Cultural Logic of Late Capitalism, p. $\mathbf{x}$.

14. See the following texts: Fredric Jameson, Postmodernism, p. 1-54; David Harvey, The Condition of Postmodernity: An Enquiry into the Origins of Cultural Change (Oxford: Blackwell, 1990), p. 39-65; Diana Coole and Samantha Frost, "Introducing the New Materialisms," New Materialisms: Ontology, Agency, and Politics, Diana Coole and Samantha Frost, eds. (Durham: Duke University Press, 2010), pp. 1-43; Levi Bryant, The Democracy of Objects (Ann Arbor: Open Humanities, 2011), pp. 1-33.

15. David Harvey, The Condition of Postmodernity, p. 54.

16. Stephan Ramsay quoted in Matthew K. Gold, “The Digital Humanities Moment," Debates in the Digital Humanities, Gold, ed. (Minneapolis: University of Minnesota Press, 2012), p. x; Ian Bogost, Alien Phenomenology or What It's Like to Be a Thing (Minneapolis: University of Minnesota Press, 2012), p. 113.

17. Bruno Latour, "Why Has Critique Run out of Steam? From Matters of Fact to Matters of Concern,” Critical Inquiry 30 (Winter 2004): 225-248, p. 225.

18. Jane Bennett, Vibrant Matter: A Political Ecology of Things (Durham: Duke University Press, 2010), p. 94; Bruno Latour, Politics of Nature: How to Bring 
the Sciences into Democracy, Trans. Catherine Porter (Cambridge: Harvard University Press, 2004), p. 246-247.

19. Ian Bogost, Alien Phenomenology or What It's Like to Be a Thing, p. 113-146.

20. For two differently situated accounts of this work on the political, see Bruno Bosteels, The Actuality of Communism (London: Verso, 2011) and Roberto Esposito, Living Thought: The Origins and Actuality of Italian Philosophy, Trans. Zakiya Hanafi (Stanford: Stanford University Press, 2012).

21. Bruno Bosteels, The Actuality of Communism, p. 80, 81.

22. Alain Badiou, The Communist Hypothesis (London: Verso, 2010), p. 232, 246; Alain Badiou, "The Idea of Communism," The Idea of Communism, Costas Douzinas and Slavoj Žižek, eds. (London: Verso, 2010), p. 1-14; Alain Badiou, "The Communist Idea and the Question of Terror," The Idea of Communism 2: The New York Conference (London: Verso, 2013), p. 1-11.

23. Alain Badiou, The Communist Hypothesis, p. 243.

24. Ibid., p. 244-245.

25. Michael Hardt and Antonio Negri, Empire, p. xi. See also, Michael Hardt and Antonio Negri's discussion of the republic of property and social democracy as two state forms that appropriate the common in Comonwealth, p. 3-21. The term "accelerationism" comes from Noyes, The Persistence of the Negative, p. 5.

26. David Harvey, The Enigma of Capital and the Crises of Capitalism (Oxford: Oxford University Press, 2010), p. 204.

27. On material feminisms, see Stacy Alaimo and Susan Hekman, eds., Material Feminisms (Bloomington: University of Indiana Press, 2008); on speculative materialism and realism see Levi Bryant, Nick Srnicek, and Graham Harman, eds., The Speculative Turn: Continental Materialism and Realism (Melbourne: re.press, 2011); on recent work in affect theory see Patricia Ticineto Clough with Jean Halley, eds., The Affective Turn: Theorizing the Social (Durham: Duke University Press, 2007) and Melissa Gregg and Gregory J. Seigworth, eds., The Affect Theory Reader (Durham: Duke University Press, 2010); for a brief introduction to world-systems analysis see Immanuel Wallerstein, WorldSystems Analysis: An Introduction (Durham: Duke University Press, 2004).

28. Diana Coole and Samantha Frost, "Introducing the New Materialisms," p. 6.

29. See Christopher Breu, Insistence of the Material: Literature in the Age of Biopolitics (Minneapolis: University of Minnesota Press, 2014), pp. 22-23.

30. Boaventura de Sousa Santos, "Introduction: Expanding the Economic Canon and Searching for Alternatives to Neoliberal Globalization," Another Production is Possible: Beyond the Capitalist Canon, Boaventura de Sousa Santos, ed. (London: Verso, 2006), p. xxxix. 
Chapter 10

\title{
Neoliberalism, Post-Scarcity, and the Entrepreneurial Self
}

\author{
UPPINDER MEHAN
}

The main character of the first part of Charles Stross' novel Accelerando, Manfred Macx, makes his living by "essentially coming up with whacky but workable ideas and giving them to people who will make fortunes with them. He does this for free, gratis. In return, he has virtual immunity from the tyranny of cash; money is a symptom of poverty, after all, and Manfred never has to pay for anything." ${ }^{1}$ Near the beginning of the novel Manfred receives a plea from an AI looking for asylum. "If survival is what you're after," he tells it, "'you could post your state vector on one of the p2p nets: then nobody could delete you ?. 'Nyet!' The artificial intelligence sounds as alarmed as it's possible to sound over a VoiP link. 'Am not open source! Not want lose autonomy!'”

Manfred's desires to be free from the bonds of cash and attempt to move to a high tech version of a gift-economy ends up employing the convenient fiction of the production of knowledge as the equivalent of the production of physical goods and services via the notion of intellectual property. As a good entrepreneur, or a large corporation that headquarters in tax-sheltered locales, Manfred is a hero in IP geek circles because "he's the guy who patented the business practice of moving your e-business somewhere with a slack intellectual property regime in order to evade licensing encumbrances." ${ }^{3}$ Yet this is the same character who finds a gulf between himself and his parents who are "still locked in the boringly bourgeois twen-cen paradigm of college-career-kids." His parents are of a generation doomed in the new economics because 
they follow the thought of "Marxist dialectic and Austrian School economics: they're so thoroughly hypnotized by the short-term victory of global capitalism that they can't surf the new paradigm, look to the longer term." 5 To be fair to Manfred's parents, and to Manfred and Charlie Stross, the last bit about Austrian School economics is directed toward an uploaded lobster neuronal network that has gained AI through a meshing with older Expert Systems.

On the one hand, Manfred fits the neoliberal ideal of the autonomous, entrepreneur who is constantly exploring business opportunities; on the other hand, Manfred sees himself as a different creature than those whose lives were lived under neoliberalism. The difference between the two may be that Manfred's parents lived as the objects of neoliberalist practice or as incomplete subjects whereas Manfred has so completely internalized neoliberal ideals that he is no longer aware of them. But such speculation leads me to step outside the formative processes of the unproblematized self constructed by neoliberal idealism and toward the complete identification between work and self that is as much a part of the capitalist, religious utopian conception of being in the world as it is the Marxist ideal of the unalienated worker.

It may also be that Manfred is in a confused state in the world of the novel because he himself is caught in a transitional state between Stross' extrapolation of the current economic and political shape of this world and the next. Most futurologists at the beginning of the $21^{\text {st }}$ century give computing and technology a central role in their forecasts. They typically call for greater interconnectedness leading to greater efficiencies of all sorts. The future for most of them is only quantitatively different from the present. There are, however, those who think our scientific and technological progress is leading us to a qualitatively different future. A small number of science fiction writers have begun to explore the contours of life after the singularity. No one is quite sure what life will be like after the singularity but all are certain that we will finally have moved into a postscarcity world. The singularity, according to Ray Kurzweil, is a "future period during which the pace of technological change will be so rapid, its impact so deep, that human life will be irreversibly transformed." The sciences and technologies which will bring this about are already here and getting us closer every year. The speed and capacity of computing 
power is growing exponentially so that soon Kurzweil hopes to be able to convert his brain into software; nanotechnology is on the verge of realizing the dreams of alchemy; and the recasting of biology into a branch of information technology will lead to the complete control over our bodies and our environments. Implicit in such a vision is the understanding that each one of us will never have to suffer from any physical want. The populating of the "us" has given some science fiction writers pause as they see little reason for the dynamics of technology transfer to change in the foreseeable future. The response to the worry of the unequal distribution of resources is that one, technology always produces cheaper iterations of itself; two, since much of the new technology is informationbased attempts at controlling its spread will fail; and three, the nature of information will force us to abandon the iniquities of classical economics which struggles with the allocation of resources under conditions of scarcity.

In the post-singularity world we may be able to full realize the self promised by neoliberal rhetoric: an autonomous, entrepreneurial self, free to make rational choices about every aspect of life. While Manfred in Stross' Accelarando may be struggling to be born into a new world, his daughter is fully a creature of a post-singularty and post-scarcity world. Manfred's daughter begins as the flesh and blood product of the union on Manfred and his ex-wife but quickly becomes something other than a daughter in our contemporary conventional sense of the word. Amber describes herself thus to another character in the novel: "I ran away from home. Mom owned me-that is, she had parental rights and Dad had none. So Dad, via a proxy, helped me sell myself into slavery to a company. The company was owned by a trust fund, and I'm the main beneficiary when I reach the age of majority. As a chattel, the company tells me what to do-legally_but the shell company is set to take my orders. So I'm autonomous."

In her examination of the move from analog to digital culture $\mathrm{N}$. Katherine Hayles proclaims at one point, "I certainly am not the autonomous liberal self that located identity in consciousness and rooted it in my ability, first and foremost, to possess my own body... I am a distributed cognitive system composed of multiple agents that are running the programs from which consciousness emerges, even though consciousness remain blissfully unaware of them." ${ }^{8}$ In blithely dismissing the liberal 
notion of the self-possession of the body she elides monumental struggles that are still with us in securing that very right to self-possession. As damaging to her position is the reductionist core of her emergent self, for there is once again the I, the I that says, thinks "I am a distributed cognitive system." If Hayles really is a distributed cognitive system, then she should be addressing herself in the royal We; we am a distributed cognitive system.

I do find myself in general agreement with Hayles with her fervent wish that soon "Operating in the economy of information, one can dream that social position and economic class will cease to matter, dream even of loosening the constraints of living in a single body located at a single position in space and time." ${ }^{\prime \prime}$ Such a wish though is what post-scarcity after the singularity promises.

On the one side the dream of freely flowing information strains to escape scarcity, restricted phusical space, class, gender, embodiment, time, and mortality; on the other side the claims of corporate profit, stratified social structures, physical confinement, gender inequalities, marked and failing bodies re-assert their inevitability. ${ }^{10}$

Hayles correctly points out the two sides of the dream, although I find it curious that on the nightmare side of the dream she places the "problem" of gender inequality, "marked" and "failing bodies" as being inevitable as corporate profit. She probably does not mean that gender, being marked, and having a failing body are the same sort of problem as corporate profit. What she may mean is that when it comes to the dream of being free of the body (disembodiment) gender could be as much a problem as being marked or feeble. So the question arises, whose body is it that is the subject of the "dream" of disembodiment? Which body is it that one can be free of in the utopia of space and time unbound? What kind of body is it that can best take advantage of life in the post-scarcity world? Obviously, one that is free of gender inequality, read "male"; a body that is not marked, read "white", a body that is not failing, read "young." In the final analysis the utopia of unlimited information and goods is threatened by corporate greed, women, non-white people, and the elderly. 
What is wrong with autonomy? Who does not want to be free from the influences of others, especially others who would hold us back from activities and projects that enable us to spend our social and cultural and monetary capital as we would see fit? The individual autonomy that is important to classic liberalism is not the same autonomy we find under neoliberalism according to Baez and Talburt. ${ }^{11}$ They argue, following Foucault, that neoliberal autonomy is a technique of governmentality. Subjects, parents of schoolchildren in the case of Baez and Talburt's analysis, are empowered to act responsibly, to choose to act responsibly, by extending the life of the school into the life of the house and thereby ensuring success for their children. "Neoliberal rationality positions subjects as actors who are "free to" and "responsible for" the administration of their own lives. Parents and children as lifelong learners are "free" to continually recreate the self through a life that "becomes a continuous course of personal responsibility and self-management of one's risks and destiny - the autonomous learners who are continuously involved in self-improvement." 12

Self-improvement and lifelong learning are transformed under neoliberalism from an active exploration of fields of knowledge to a necessary re-calibration of skills attuned to the shifting demands of the marketplace.

The autonomous self under Neoliberalism is also being burdened with responsibility when it comes to health care. The discourse of making the delivery of health care efficient is centered on cutting costs. A number of aspects of the health care equation are available for furthering the reduction of costs, various expensive tests requiring exotic machinery and specialized labor, newer medication invented by Big Pharma, fees charged by physicians, and administrative costs of insurance companies, among others; however, the emphasis in neoliberal critiques falls most heavily on reducing the services available to the patient.

A more insidious neoliberal approach echoes the personal responsibility trope offered above in Baez and Talburt's application of the notion of governmentality to schoolchildren and their parents. The patient is "empowered" in neoliberalist ideology to manage his or her health, choose the best insurance plan, and select the best physician. As Evans et al. point out no other aspect of health care responsibility has been shifted 
to patients in contemporary culture more completely than obesity. ${ }^{13}$ It falls on the patient to manage his or her obesity not only for a better quality of life but also to aid in the effort to rein in national healthcare costs. The focus is less on the delivery of healthcare and more on the regimen required to be an ideal patient. I'm not arguing that it is not in the best interest of the individual to manage weight within reason but the onus on the responsible individual self ignores the market and structural dimensions of inexpensive, high-caloric food made readily available through heavy subsidies to large agriculture corporations.

Should the neoliberal self either not be interested in managing his or her weight then there is the option of surgery. Currently, lap band surgery at $\$ 12,000$ is covered by health insurance plans, including Medicare, if the patient has a BMI of at least 35 (80 to 100 pounds over the recommended weight), a history of related health problems (diabetes, jointpain, and heart disease), and repeated attempts at dieting. ${ }^{14}$ If the patient has difficulty qualifying under the above conditions, then one website for a Bariatric Surgery center advises that "there may be a way to have some of the tests covered, or perhaps have another (approved) abdominal surgery done simultaneously thereby covering some of the anesthesia and hospital fees." ${ }^{14}$ The FDA is under pressure, as of mid-January 2011, by a maker of lap band devices to approve the surgery for people who are only slightly obese.

A number of meanings overlap from almost the beginning of the uses of the word autonomy. According to the OED, the earliest uses of the word come to us from its political usage. So H. Cockeram in 1623 defines autonomy as the "liberty to live after one's own law," but just a few years later More is cited using it in a more inclusive sense, making the move from the individual to a collective. In a biblical history More, in 1681, says that the Jews were granted autonomy, "viz. liberty of living according to their own laws." The editors of the OED choose an interesting example in their attempt to illustrate the fuller meaning of autonomy as the "liberty to follow one's will, personal freedom." Here is the example in full: "1803 W. Taylor in Ann. Rev. 1384 The customers of a banker can desert to a rival at will, and thus retain an autonomy of conduct." Given such an entangled beginning it is less surprising that we have such conflicting 
meanings today. The conflicting meanings also carry into conflicting and contradictory values given to autonomy.

Autonomy, of course, has a much longer philosophical history and it is beyond the scope of this essay (and my expertise) to give other than a brief caricature of sorts. Both Plato and Aristotle hold that personal autonomy as self-determination is an ideal for humanity and for both this ideal is associated with rationality. The Stoics continue this preference and autonomy develops in the Enlightenment into Rousseau's concept of autonomy as moral liberty undergirded by the twin notions of mastery over oneself and civil liberty. For Kant moral autonomy resides in having one's will determine its own guiding principles rather than having them dictated by external figures such as religious authorities and imposed legislation. Rationality still serves as a keystone in Enlightenment ideals and acts as a break on autonomy as the fulfillment of idiosyncratic desires.

But what Rousseau and Kant see as the workings of universal reason and the rational in the human the Romantics see as the stultifying of the emotional truth of the self. Particularity and individuality drive the emphasis placed upon the passions over reason in search of the complete self rather than the incomplete wizened rational self. John Stuart Mill agrees with the Romantics that the "person whose desires and impulses are his own-are the expression of his own nature, as it has been developed and modified by his own culture-is said to have a character. One whose desires and impulses are not his own has no character, no more than a steam engine has a character." ${ }^{16}$ And it is with Mill that autonomy can be said to be associated with liberalism. Would Mill, however, associate "impulses and desires" with the wildness of the Romantics? A careful reading suggests he would not. "Desires and impulses" are for Mill nature modified by the person's own culture by which I take him to mean a kind of comprehension, discernment and control developed by experience. The autonomous self for Mill is an expression of individuality and diversity in a social setting.

It is this linking between liberalism and autonomy, and its extension into neoliberalism, that is of interest to me in this paper and Bhiku Parekh's criticism of Mill serves as a turn in the criticism of autonomy that has gained ground over the second half of the twentieth century. Parekh holds that "since Mill's theory of diversity was embedded in an 
individualist vision of life, he cherished individual but not cultural diversity, that is diversity of views and lifestyles within a shared individualist culture but not diversity of cultures including the nonindividualist." ${ }^{17}$ While Parekh's point is well taken from a multiculturalist perspective, feminist scholars such as Carol Gilligan wonder whether autonomy may be a gendered value, and contemporary philosophers such as Levinas recommend heteronomy over autonomy.

The criticism of autonomy that I want to take up in its neoliberal iteration is that offered by communitarians who argue that the liberal emphasis on the autonomy of the self inadequately recognizes the self in its social and political embeddedness. Communitarians, according to Cha, argue that "neo-liberalism is simply revived old-fashioned, economic liberalism, and it means unbridled individualism in the market place, and in the political arena where unfettered individualism allows the economically elite to effectively maintain a position of power." ${ }^{18}$

Cha's dismissive phrase equating Neoliberalism with economic liberalism has some merit in that it underscores the linkage between the two forms. But the qualifying "simply revived" is too facile. To begin with there is an older European Neoliberalism and a more recent American Neoliberalism from the 1980s. The earlier continental Neoliberalism is the one associated with the Austrian School of Economics and then later with the Chicago School and Pinochet's Chile. This is also the Neoliberalism of David Harvey's A Brief History of Neoliberalism, who extends it include Thatcher's England and Reagan's America. The American Neoliberalism of Charles Peters, Gary Hart, and Robert Reich begins with Reagan's term.

In the May 1983 issue of The Washington Monthly Charles Peters published "A Neoliberal's Manifesto" as a call to liberals in America to re-examine closely held ideas of governance. As he relates in an interview on the Washington Monthly website in 2007, "In the late seventies, there was this stagnation, and you desperately needed a rebirth of entrepreneurship. The neoliberals can't take complete credit for this rebirth, because it was happening right as we were calling for it. It began to happen with people like Bill Gates and the Apple guy in their garages. Things were ready to explode. But as in so many revolutions that are desirable, it went too far." ${ }^{19}$ A measure of the distance between European and 
American Neoliberalism is that Charlie Peters supports a nationalized health care system.

In addition to the writers at The Washington Monthly, Peters' introduction to his manifesto names reporters from The Atlantic, Texas Monthly, and Newsweek, along with academics such as Robert Reich and Lester Thurow, and politicians such as Gary Hart, Paul Tsongas and Bill Bradley as fellow travelers. The opening move of the manifesto is to frame Neoliberalism as an attempt to start thinking again rather than responding automatically to the problems of the country. So neoliberals do not want to automatically "favor unions and big government or oppose the military and big business." ${ }^{20}$ In addition to economic stagnation, neoliberals see a crumbling infrastructure, inefficient public agencies, a topheavy military, and selfish politicians beholden to special interest groups. The liberals lack of solutions come from having fallen prey to four principles: Don't Say Anything Bad about the Good Guy, Pull up the Ladder, The More the Merrier, and lastly Politics is Bad and Politicians are even Worse. All of which necessarily lead to the unquestioning acceptance of the status quo: public schools, the civil service and unions are not to be alienated, the more beneficiaries a program has the more likely it is to survive politically, and public institutions such as the Post Office are to be free of government control and influence. American neoliberals focus, instead, on "encouraging entrepreneurship" not by adopting "Reaganite policies that make the rich richer" but by providing a more inviting environment for investors and customers and by increasing competition. But such actions are to take place with the understanding that "on the matters of health and safety ... there must be vigorous regulation, because the same capitalism that can give us economic vitality can also sell us Pintos, maim employees, and pollute our skies and streams." ${ }^{21}$

The more details Peters provides in his manifesto the less certain I am there is that much difference between American Neoliberalism and the European Neoliberalism which sees its ideas turned into policies that are most significantly first put into effect in Latin and South America. Perhaps, there is one significant difference between the two neoliberalisms, Peters' manifesto is silent on the issue of free trade. The importance of free trade to the Neoliberalism inflicted on southern countries makes it central to most of its other positions on the economy, government, 
and understanding of the individual self; perhaps, it is that missing piece in American Neoliberalism that makes it possible for Democrats in the 1980s (some would say including the Clinton and Obama administrations) to view their actions as corrections rather than capitulations.

Hayek and Friedman's Neoliberalism (European Neoliberalism) believes that "the individual is generally the best judge of his or her interests, and that economic ends are generally best pursued through a market system involving private ownership and contractual exchange." 22 Economic ends may have been the beginning of Neoliberalist concerns but the ends have multiplied and now seem to reach into every aspect of human (and non-human) life: or as David Harvey puts it, "the commodification of everything." 23 The ethics of neoliberalism frame the free market transaction as both duty and consequence. Neoliberal thinking is manifest in higher education primarily through the on-going attempt to turn universities into enterprise systems in which the student/consumer is sold a quantifiable good by the entrepreneur/teacher and the whole process can be assessed for its accuracy, validity, and efficiency. The student and the teacher are partners in an exchange in which both of them are tasked with making choices. The capacity to make rational choices figures as highly in education as it does in health care where the onus is on the individual to become the shaper of his or her body. The discourse of health care increasingly mimics the discourse of management. The rational self assesses the performance needs of the body, purchases the products and knowledge necessary to maintain the body in good working order, and adopts the required pharmaceutical and "lifestyle" regimes. Such a perspective on health is not new with neoliberalism but it has certainly acquired a greater market share than ever before.

The student, the teacher, the health consumer, the worker are all entrepreneurs in neoliberal thought. Each individual a company of one that enters into contractual engagements with other companies. An entrepreneur, by definition, responds to market forces by assessing the needs of the marketplace and supplying those needs. As the market forces change so too does the entrepreneur in response. The original capitalist understanding of the entrepreneur is the individual as investor. According to BusinessDictionary.com, an entrepreneur is a "Person who exercises initiative by organizing a venture to take benefit of an opportunity and, as 
the decision maker, decides what, how, and how much of a good or service will be produced. He or she supplies risk capital as a risk taker, and monitors and controls the business' activities as a manager. The entrepreneur is usually a sole-proprietor, a partner, or the one who owns the majority of shares in an incorporated venture." BusinessDictionary.com is owned by Web Finance Inc., "an internet company that strives to provide educational tools in a wide range of subject areas." The site informs us that the company's "goal is to help as many people as possible, and for this reason everything [they] provide is free." In case you are wondering Walden University and Chase Bank were the two advertisers on the webpage offering me easy credit and the opportunity to make a difference in my community (I leave it to you to match advertiser and offer).

At the heart of the vision of the entrepreneur is the necessity of contracts, and the arguments Plato gives to Socrates for the necessity of contracts with their basis in enlightened self-interest have been echoed throughout history. People come together and are ruled by giving consent to the state. Alongside such an understanding, however, is also an awareness that, at root, the consent is based on force. Hume's thoughts on the original contract lead him to pronounce that "Almost all the governments which exist at present, or of which there remains any record in story, have been founded originally, either on usurpation or conquest, or both, without any presence of a fair consent or voluntary subjection of the people." The promoters of neoliberalism would respond by pointing out that that inequality is exactly the problem that entrepreneurship, that contracts entered into freely, are best at combating. As Hart and Holmstrom point out, however, contracts always spell out enforcement issues. They do sketch a case of the parties to a contract behaving responsibly toward each other, honoring the terms of their contract without recourse to legally binding penalties: "a party may behave "reasonably" even if he is not obliged to do so in order to develop a reputation as a decent and reliable trader" (102). But Hart and Holmstrom emphasize that such behavior depends on a shared understanding of the terms of the contract, shared norms of behavior, and equally shared information. The free exchange between parties that freely enter into an agreement is the utopian dream of contemporary capitalists from Adam Smith's liberals to Milton Friedman's neoliberals. However, “Adam Smith's economic 
agents are not just isolated individuals, they are property owners, and it is because they are the owners of property that some have the power, embodied in legal right, to profit from the labor of others" (Clarke 52).

I began this essay with a brief look at Charles Stross' Accelerando and ended with the main character of the second half of the story, Amber, the daughter born in a post-singular, post-scarcity world. At a key point in her psychological development she rebuffs a "traditional" understanding of family and relationships when she interrupts a homily about "a mother's love," "Fuck love ... she wants power." 24 The rest of the novel in which she and her band of explorers upload versions of themselves into a tin can of a spaceship, heading out to meet alien info-traders, follows the same trajectory that Hayles' points out in her analysis of three fictions covering a span from the end of the nineteenth century to the 1970s. New information first allows the protagonist to escape from her known limitations but then a realization sets in that the escape is actually a new "arena in which the dynamics of domination and control can be played out in new ways." 25

I'll end with making use of Appiah's useful distinction between strong autonomy and weak autonomy. Neoliberal idealists value strong autonomy which sees the individual as fully capable of making rational decisions about all aspects of his or her life. Communitarians recognize all the ways in which the self is both a problematic on-going construction pulled in various directions by internal and external forces to such an extent that the boundary between external and internal ceases to register. Appiah's suggestion is that weak autonomy, "an availability of options, an endowment with minimum rationality, an absence of coercion" ${ }^{26}$ may actually be what those who think of autonomy as a value may be advocating. Such a sense of autonomy seems to me something most of us can work with.

\section{Works Cited}

Appiah, Kwame Anthony. The Ethics of Identity. Princeton, New Jersey: Princeton University Press, 2005.

Baez, Benjamin and Susan Talburt. "Governing for Responsibility and with Love: Parents and Children between Home and School." Educational Theory 58.1 (2008): 25-43. 
Cha, In-Suk. “Reform Liberalism Reconsidered.” Diogenes 48.192 (Winter 2000): 97-103.

Evans, John, Emma Rich, Brian Davies, and Rachel Allwood. Education, Disordered Eating and Obesity Discourse: Fat Fabrications. London, England: Routledge, 2008.

Hart, Oliver and Bengt Holmstrom. The Theory of Contracts. 1985. Internet Archive. 2011. Web. 25 June 2012.

Harvey, David. A Brief History of Neoliberalism. New York: Oxford University Press, 2005.

Hayles, N. Katherine. My Mother was a Computer: Digital Subjects and Literary Texts. Chicago: University of Chicago Press, 2005.

Hodgson, Geoffrey M. "Knowledge at Work: Some Neoliberal Anachronisms." Review of Social Economy LXIII.4 (December 2005): 547-565.

Hume, David. "Of the Original Contract." Essays, Moral, Political, and Literary. Ed. Eugene F. Miller. Indianapolis: Liberty Fund, Inc., 1987. First Published Part I: 1742. Part II (Political Discourses): 1752. Combined: 1777. http://www.econlib. org/cgi-bin/cite.pl Web. 26 June 2012.

“Insurance Coverage for the Lap Band Procedure." Bariatric Surgery Specialists. n.d. http://lapband.obeseinfo.com/

Klein, Ezra. "A Neoliberal Education: David Brooks thinks neoliberalism is dead. Charles Peters begs to differ." The Washington Monthly (May 2007). http://www. washingtonmonthly.com/features/2007/0705.klein.html

Kurzweil, Ray. The Singularity is Near. New York: Viking, 2005.

Mill, John Stuart. On Liberty. Indianapolis and New York: The Liberal Arts Press, 1956.

Peters, Charles. “A Neoliberal's Manifesto.” The Washington Monthly (May 2007; originally published May 1983). www.washingtonmonthly.com/ features/1983/8305_Neoliberalism.pdf

Stross, Charles. Accelerando. New York: Penguin, 2005.

Zuckerman, Diana. "Playing With the Band." The New York Times (11 January 2011). http://www.nytimes.com/2011/01/12/opinion/12zuckerman.html?_r=0

\section{Notes}

1. Charles Stross, Accelerando (New York: Penguin, 2005), Chapter 1, 10/59. 
2. Ibid., Chapter 1, 7/59.

3. Ibid., Chapter 1, 9/59.

4. Ibid., Chapter $1,8 / 59$.

5. Ibid.

6. Ray Kurzweil, The Singularity is Near (New York: Viking, 2005), p. 7.

7. Charles Stross, Accelerando, Part 2, Chapter 1, 44/77.

8. N. Katherine Hayles, My Mother was a Computer: Digital Subjects and Literary Texts (Chicago: University of Chicago Press, 2005), p. 213.

9. N. Katherine Hayles, My Mother was a Computer, p. 63

10. Ibid., p. 64 .

11. Benjamin Baez and Susan Talburt, "Governing for Responsibility and with Love: Parents and Children between Home and School," Educational Theory 58.1 (2008): 25-43.

12. Baez, Benjamin and Susan Talburt. "Governing for Responsibility and with Love," p. 16.

13. John Evans, Emma Rich, Brian Davies, and Rachel Allwood, Education, Disordered Eating and Obesity Discourse: Fat Fabrications (London, England: Routledge, 2008).

14. Diana Zuckerman, "Playing With the Band," The New York Times (11 January 2011). http://www.nytimes.com/2011/01/12/ opinion/12zuckerman.html?_r=0

15. "Insurance Coverage for the Lap Band Procedure," Bariatric Surgery Specialists, n.d.http://lapband.obeseinfo.com/

16. John Stuart Mill, On Liberty (Indianapolis and New York: The Liberal Arts Press, 1956), p. 73.

17. Kwame Anthony Appiah, The Ethics of Identity (Princeton, NJ: Princeton University Press, 2005), p. 42.

18. In-Suk Cha, “Reform Liberalism Reconsidered,” Diogenes 48.192 (Winter 2000): 97-103, p. 98.

19. Ezra Klein, "A Neoliberal Education: David Brooks thinks neoliberalism is dead. Charles Peters begs to differ," The Washington Monthly (May 2007). http://www.washingtonmonthly.com/features/2007/0705.klein.html

20. Charles Peters, “A Neoliberal's Manifesto,” The Washington Monthly (May 2007; originally published May 1983), p. 9. www.washingtonmonthly.com/ features/1983/8305_Neoliberalism.pdf 
21. Charles Peters, “A Neoliberal's Manifesto,” p. 11.

22. Geoffrey M. Hodgson, "Knowledge at Work: Some Neoliberal Anachronisms," Review of Social Economy LXIII.4 (December 2005): 547-565, p. 547.

23. David Harvey, A Brief History of Neoliberalism (New York: Oxford University Press, 2005), p. 165.

24. Charles Stross, Accelerando, Part 2, Chapter 1, 54/77.

25. N. Katherine Hayles, My Mother was a Computer, p. 65.

26. Kwame Anthony Appiah, The Ethics of Identity, p. 40. 



\section{Notes on Contributors}

Andrew Baerg is Chair of Humanities and Associate Professor of Communication at the University of Houston-Victoria. His research interests include media and social theory, digital game studies, media and sport, and neoliberalism.

Christopher Breu is Associate Professor of English at Illinois State University, where he teaches classes in twentieth and twenty-first century literature and culture as well as cultural and critical theory. $\mathrm{He}$ is the author of Insistence of the Material: Literature in the Age of Biopolitics (2014) and Hard-Boiled Masculinities (2005).

Jodi Dean is the Donald R. Harter '39 Professor of the Humanities and Social Sciences at Hobart and William Smith Colleges. Her research includes political theory, digital media and politics, poststructuralism and psychoanalysis, neoliberalism and consumerism, cultural studies, and feminist theory. Her books include Publicity's Secret (2002), Democracy and Other Neoliberal Fantasies (2009), Blog Theory (2010), and The Communist Horizon (2012).

Noah De Lissovoy is Associate Professor of Cultural Studies in Education in the Department of Curriculum and Instruction at the University of Texas at Austin. His research focuses on critical approaches to pedagogy, educational theory, and cultural studies, as well as on problems posed for educators by globalization. He is the author of Power, Crisis, and Education for Liberation, and co-author of Toward a New Common School Movement. His articles have appeared in many journals and edited collections.

Jeffrey R. Di Leo is Dean of the School of Arts \& Sciences and Professor of English and Philosophy at the University of HoustonVictoria. He is editor and publisher of American Book Review, and the founder and editor of symploke. . His most recent books are Neoliberalism, 
Education, Terrorism: Contemporary Dialogues (2013, with H. Giroux, S. McClennen, and K. Saltman), Corporate Humanities: Moving Beyond the Neoliberal Academy (2013), and Turning the Page: Book Culture in the Digital Age (2014).

Robert P. Marzec is associate professor of ecocriticism and postcolonialism in the Department of English at Purdue University. He is the author of An Ecological and Postcolonial Study of Literature (2007), the editor of Postcolonial Literary Studies: the First 30 Years (2011), and the associate editor of Modern Fiction Studies. He has published articles in journals such as boundary 2, Radical History Review, Public Culture, The Global South, and The Journal of Commonwealth and Postcolonial Studies. His new book Environmentality: the Rise of the Security Society in the Age of Climate Change is forthcoming.

Uppinder Mehan is Dean of Arts and Sciences and Associate Professor of English at Fort Valley State University. He is editor, with Nalo Hopkinson, of So Long Been Dreaming: Postcolonial Science Fiction and Fantasy, and his essays have appeared in Comparative Literature, Paragraph, and Foundation: The International Review of Science Fiction.

Paul A. Passavant, is author of No Escape: Freedom of Speech and the Paradox of Rights (2002). He is also, with Jodi Dean, the editor of Empire's New Clothes: Reading Hardt and Negri (2004). In addition to policing protest, his studies include neoliberalism and the state, torture and surveillance, and politics and society beyond law and the state. $\mathrm{He}$ is an Associate Professor of Political Science at Hobart and William Smith Colleges.

Jennifer Wingard is an Assistant Professor of Rhetoric, Composition, and Pedagogy at the University of Houston. Her main area of research is the impact of global neoliberal economics on local civic discourses. Her research interests also include the rhetoric(s) of protest, media literacy, feminist rhetoric(s) and theories, and critical pedagogy. She is the author of Branded Bodies, Rhetoric, and the Neoliberal Nation-State (2012).

Zahi Zalloua is Associate Professor of French and Interdisciplinary Studies at Whitman College and editor of The Comparatist. He has 
published Montaigne and the Ethics of Skepticism (2005) and Reading Unruly: Interpretation and its Ethical Demands (2014). He has edited two volumes on Montaigne, Montaigne and the Question of Ethics (2006) and Montaigne After Theory, Theory After Montaigne (2009), and has also published articles, edited volumes and special journal issues on globalization, literary theory, ethical criticism, and trauma studies. 
Capital at the Brink reveals the pervasiveness, destructiveness, and dominance of neoliberalism within American society and culture. The contributors to this collection also offer points of resistance to an ideology wherein, to borrow Henry Giroux's comment, "everything either is for sale or is plundered for profit." The first step in fighting neoliberalism is to make it visible. By discussing various inroads that it has made into political, popular, and literary culture, Capital at the Brink is taking this first step and joining a global resistance that works against neoliberalism by revealing the variety of ways in which it dominates and destroys various dimensions of our social and cultural life.

Jeffrey R. Di Leo is Dean of the School of Arts \& Sciences and Professor of English and Philosophy at the University of Houston-Victoria. He is editor and publisher of American Book Review, and the founder and editor of symploke. His recent books include Neoliberalism, Education, Terrorism: Contemporary Dialogues (2013, with H. Giroux, S. McClennen, and K. Saltman), Corporate Humanities: Moving Beyond the Neoliberal Academy (2013), and Turning the Page: Book Culture in the Digital Age (2014).

Uppinder Mehan is Dean of Arts and Sciences and Associate Professor of English at Fort Valley State University. He is editor, with Nalo Hopkinson, of So Long Been Dreaming: Postcolonial Science Fiction and Fantasy, and his essays have appeared in Comparative Literature, Paragraph, and Foundation: The International Review of Science Fiction.

Cover Image: Original photograph @ 2014 cc-by-sa Bjørn Christian Tørrissen, cropping and coloration by OHP. Original available at http://commons.wikimedia.org

Series: Critical Chimate Change

()

OPEN HUMANITIES PRESS 